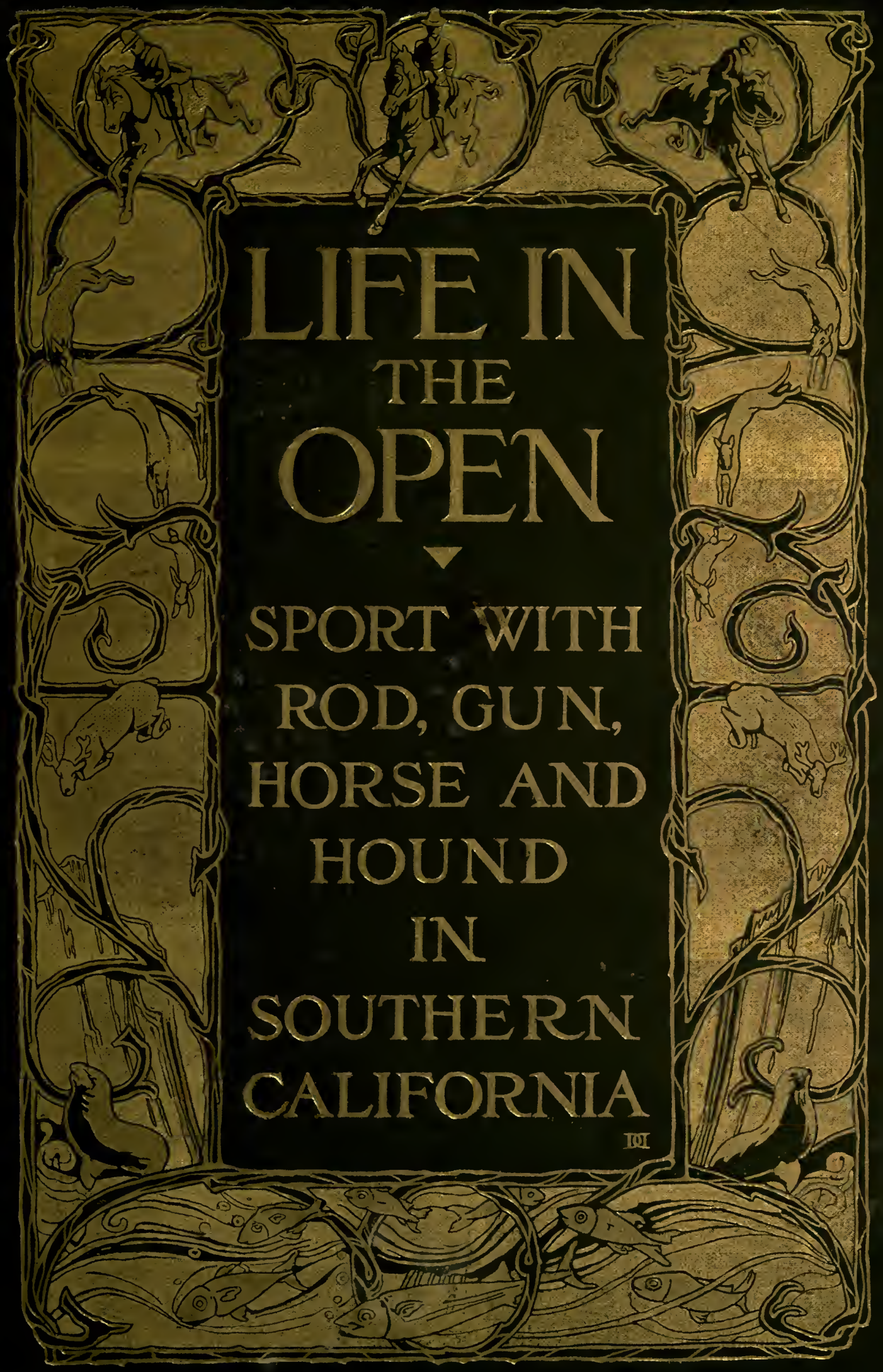




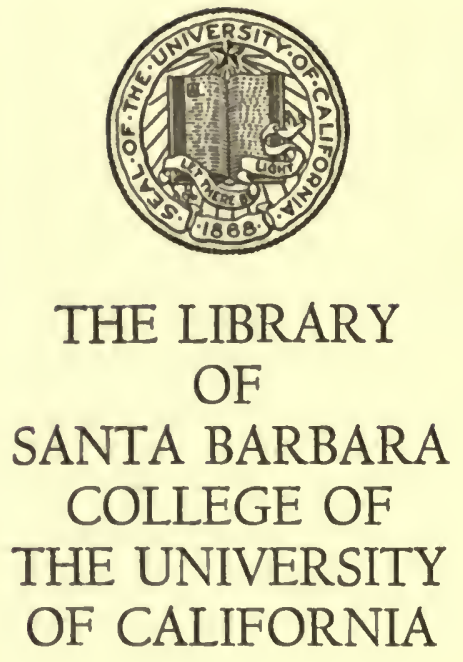

PRESENTED BY

MR.AND MRS.R.W.VAUGHAN 
c. 
Digitized by the Internet Archive in 2007 with funding from Microsoft Corporation 





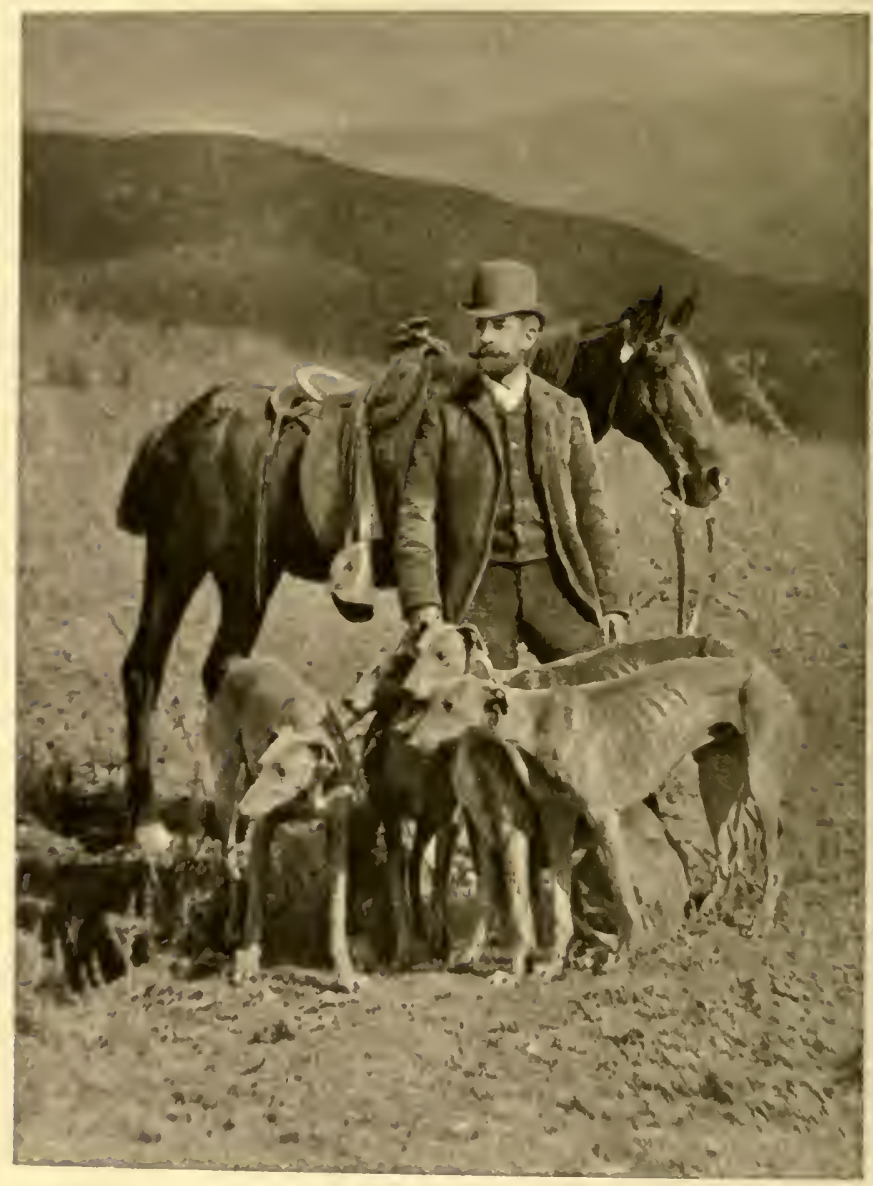




\title{
Life in the Open
}

\section{Sport with Rod, Gun} Horse, and Hound

\author{
In

\section{Southern California}

By

\section{Charles Frederick Holder}

Author of "Life of Charles Darwin," "The Big Game Fishes"

"The Adventures of Torqua," etc.

Illustrated

G. P. Putnam's Sons

New York and London

Tbe Iknickerbocker press

I 906 
Copyright, Ig06

BY

CHARLES FREDERICK HOLDER

Tbe knickerbocker press, Rew pork 


\section{Preface}

T $\mathrm{N}$ presenting these impressions of outdoor life and sport in Southern California during twenty or 1 more years along shore and the Sierra Madre, I should perhaps say that the point of view has been one of personal experience alone, and the hunting days described are as I found and tried to make them.

$\mathrm{My}$ conception of sport does not include a desperate killing, a plethoric bag or creel ; the game is merely an incident in the day, and in the splendid cañons of the Sierra Madre, I confess, has often been forgotten. A hunting day, at least to my mind, should include a drawing for all the senses, not game alone, but the enjoyment of the flora, the variety in mountain view, the vistas of different kinds, the charming changes of colour and tone that sweep over the range as the hours pass, and the thousand and one diversions which nature always affords.

Southern California lends itself particularly to such a definition of sport; its hunting grounds are staged with unwonted effects-lofty mountains, pallid deserts, seas of turquoise abounding not only in countless game fishes, but in a marvellous variety of living forms which appeal to the sportsman and fill out his days with æsthetic as well as practical experiences.

iii 
There is hardly wild game, big or small, in America that is not menaced by the spectre of extinction, and were it not for game laws, clubs of gentlemen, sportsmen of various kinds, wild life would in a short time disappear from the face of the earth. It should be the duty of every sportsman to conserve the gifts of nature. Sport with the gun, rod, spear, and hound is legitimate and manly, but there is an unwritten law among gentlemen that no sportsman will kill more than the camp demands, or rational sport justifies. The rod catch of tarpons last season at Tarpon, Texas, was nearly eight hundred fish, yet every one not needed as a trophy was released. I can conceive no greater example of selfcontrol than that illustrated by the angler who stops fishing when but two tunas have been caught, though the waters are covered with schools eager for the lure; yet I have witnessed this marvellous thing.

Southern California is an open book the year around. Every day, winter or summer, has its invitation to the lover of sport or nature; not only in the south but throughout the length of the land. The present volume is confined to Southern California, as to cover the entire State adequately would require much more space. Northern California possesses even greater natural wonders than the south and more big game, at least among land animals. The section described includes the region south of Point Conception, the counties of Santa Barbara, San Buenaventura, Los Angeles, San Bernardino, Riverside, Orange, 


\section{Preface}

and San Diego, or, in brief, the lower part of the State.

The conditions are so different from those in Eastern America, the winter being the season of flowers, the entire year an open one, inviting sports and varied pastimes, that I have tried to convey to the reader some idea of "life in the open" in the various seasons, what to expect winter, or summer, in this land of the palm and orange, and to a certain extent to answer some of the questions relating to the country which I have often been asked. Thus, to the world at large, Southern California is merely a winter resort. This is a popular misconception. It is, to my mind at least, a far better summer resort, and the dwellers along its shores and among the channel islands know an almost perfect summer climate, and never experience the intense often deadly, heat of the Atlantic seaboard. The truth about Southern California is that it is an all-the-yearround land, where it can honestly be said the disagreeable features of life and climate are reduced to the minimum.

Southern California is so cosmopolitan that it belongs to all America, and in this oasis between the desert and the deep sea the country has a possession that will prove in years to come one of its most valuable assets. Yesterday it was a great ranch; to-day it is a principality, and has taken its place among the great and active centres of life, health, and commerce of the world.

C. F. H.

Pasadena, California. 



\section{Contents}

CHAPTER I.

Across Country with Greyhounds

CHAPTER II.

HUnting The LynX

CHAPTER III.

Deer-Hunting in the Southern Sierras .

CHAPTER IV.

Water Fowl $+\quad \cdot \quad \cdot \quad \cdot$ c

Fox-Hunting in Southern California . . . . 63

CHAPTER VI.

A Rainbow in the Sierra Madre $\quad . \quad$. $\quad . \quad$. 79

CHAPTER VII.

Following THE LOWLAND WOLF . . . . . TOI

CHAPTER VIII.

Shore ANd OTher Birds

CHAPTER IX.

The BighorN

\section{CHAPTER IX.}


CHAPTER XI.

The Valley Quail .

CHAPTER XII.

The Heart of the Desert

CHAPTER XIII.

El Camino Real

CHAPTER XIV.

Life in the Sierra Madre

CHAPTER XV.

The WiLd Goat on Orizaba -
CHAP'TER XVI.

The Rise of Don Antonio $\cdot \cdot$
ChAPTER XVII.

The Royal Catch

CHAPTER XVIII.

Santa Catalina Island $\cdot \cdot \cdot$
CHapter XiX.

The Sea Lion's DeN

CHAPTER XX.

Trolling in DeEP WATER . . . . 299

CHAPTER XXI. 


\section{CHAPTER XXII.}

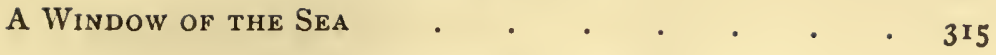

CHAPTER XXIII.

Cruising among the Channel Islands

CHAPTER XXIV.

The Still Angler

CHAPTER XXV.

The Tribe of Seriola

CHAPTER XXVI.

The Climate

Appendix . . . . . . . . . . 38 r

Game Laws . . $\quad . \quad$. . . . 387

INDEX . $\quad . \quad \cdot \quad \cdot \quad \cdot \quad \cdot \quad \cdot \quad \cdot 397$ 



\section{Illustrations}

Charles F. Holder and the Valley Hunt Hounds.

Winter Blossom of the Eucalyptus

Frontispiece

Ruins of the Chapel Mission of San Juan Capistrano, on El Camino Real

A Sudden Turn, observed by the Author . . • 8

Charles Winston's Sunny Slope Hounds

Photo by $\dot{\text { Crandall }}$

Walk at the Mission of Santa Barbara on El Camino

REAL

The Treed LynX .

Lynx Hunting, Cañada Santiago, near Orange . . 22

Treed Lynx. Santiago Club, near Fullerton a . 24

The Bells of Mission San Gabriel Arcangel, near Pasadena . . . . . . . . 28

Valley Hunt Fox HuUnds-Pasadena - Photo by Crandall 30

The Trail of the Lynx Hunters, near El Toro . . 34

California Holly, Adenostoma Photo by Graham

HE VISITS RANCH GARDENS EARLY IN THE MORNING • $\mathbf{4}^{2}$ 


\section{DEER IN THE OPEN}

Bringing in the Ducks at Balsa Chica

Mission of San Juan Capistrano on the King's Highway 54

A Good Day for Canvas-Backs at Balsa Chica • 58

An Hour's Goose Shooting . . . . . . 60

The TREed Fox . . . . . . . . . . 63

Winter Life in the Open near Pasadena Photo by Graham 70

Fox-Hunting Country near Orange, Santiago Mts. 74

Photo by Graham

Rainbow Trout-Bear Valley Lake . . . 79

The Stairs of the Mission of San Gabriel Arcangel, near Pasadena on the King's Highway - . Photo by H. A. Parker

Doctor Page casting in the upper Big Pool, Deep

Creek, San Bernardino Range . . . . 88

Winter in the Sierra Madre near San Diego • 92

The North Fork of the San Jacinto River, San Jacinto Mountains . . . . . . . . . 98

The Santiago Hunt . . . . . . . . . . ior

In at the Death, Santiago Hunt near Orange . . Io8

San luis Obispo de Tolosa on El Camino Real (King's Highway) • • • Photo by Putnam \& Valentine

Santiago Hunt Breakfast near Santa Ana . . . il6

The Waves at Coronado $\quad$ - . . . . II9

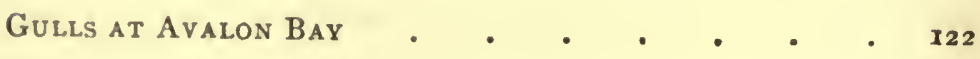




\section{Illustrations}

xiii

Castle Rock, Santa Barbara

Mount San Antonio from Redlands.

I 27

Mount San Jacinto

135

Garden of the Mission of Santa Barbara in El Camino REAL

Haunts of the Mountain Lion, and Grizzly Peak .

Pasadena in IVinter. Flowers and Snow . . .

Haunts of the Valley Quail near Pasadena Country Club

Decanso Bay-A White Sea-Bass Corner, Santa Catalina 160 Photo by Chas. Ironmonger

A Cactus Garden 165

A Desert Forest. Native Palms near Palm Springs, California Photo by Putnain \& Valentine

Candle Cactus. Lower California and Arizona Photo by Putnam \& Valentine

Mission of Santa Barbara

Pampas Grass, San Diego, on El Camino Real

Photo by II. A. Clarke

Palms of the Mission of San Fernando Rey on the King's Highway - • • • Photo by C. $\dot{C}$. Pierce

An Avenue of Palms, Los Angeles . . . . . 194

Mission of San Diggo de Alcala and Date Palms on El Camino Real • • • • Photo by C. C. Pierce

Mission of San Luis Rey de Francia on the old King's HIGHWAY

Ruins of the Mission of San Antonio de Pala . . 206 
Orange Tree

Mission or San Buenaventura on El Camino Real
Photo C. C. Pierce

Elephant Heads and Caves of la Jolla near San Diego 214

Santa Anita Ranch, Arcadia, San Gabriel Valley 218

Cluster lily, Brodiea

Wild Goat Shooting froma Boat, Santa Catalina . 228

A Black Sea-Bass Tournaments • • • • • 235

Catch of a Black Sea-Bass with Rod and Reel . 240 Photo by Chas. Ironmonger

La Purissima Concepcion Mission on the King's Highway 248

Mission of San Miguel on El Camino Real (King's HighWAY) • • . . . . . • • • 254

A Morning Catch by the Author • • • • 259

Landing the Leaping Tuna . . . . . 268

Letting Them Out • . . . . . . . 273

Six-in-Hand Swinging Around the Loop • • $\quad 278$

Bird's-Eye View of the Coach Road • . . . 284

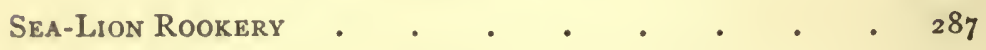

Sea-Lion Rookery at Santa Catalina Island • • 294

Typical Fishing Boat and Yellow-Fin Albacore • • 299

Catch of Black Sea-Bass and Albacore at Santa

Catalina by a Waiting Member of the Ananias Club 302

The Oceanic Bonito • • Photo by Chas. Ironmonger

304

Mr. Harding's Record White Sea-Bass . . . . 307 


\section{Illustrations}

Mount San Antonio (xo, 120 feet), Home of Mountain

SHEEP .

PAGE

312

The Glass-Bottom Boats of Avalon

315

Black and White Sea-Urchins

IN THE HaNGING GARDENS.

Photo by P. Reise

318

Photo by Chas. Ironmonger

322

The Glass-Bottom Boat, Santa Catalina Island .

324

Avalon

327

The Bay and Vale of Avalon

Photo by Chas. Ironmonger

$33^{2}$

Fern Cafon, Santa Cruz Island • · Photo by P. Reise $33^{6}$

The Vale of Avalon. Picturesque Golf Links at Santa Catalina.

Gaffing at Sheeps' Head, Santa Catalina Island • 34I

Beach Fishing for Leaping Sharks, Catalina Harbour Photo by Chas. Ironmonger

A 300-Foot Wave at San Pedro . . Pho 346

A Morning's Rod Catch of Yellow-Tail . • . 349

TAKING THE Yellow-TAIL . . . . . . . $35^{2}$

A Good Corner for Yellow-TaIL . • • • 356

The Gold of Ophir Rose . . . . . . . 359

Winter Flowers at Altadena, San Gabriel Valley $\quad 362$ Photo by H. A. Parker

Winter Verdure in Southern California • • . 366 Photo by H. A. Parker

A Redlands Orange Grove and Home in Winter • • 368

Pasadena's Varied Climates . . . . . . 374

Pasadena's Varied Climates (Continued) . • • . 378 



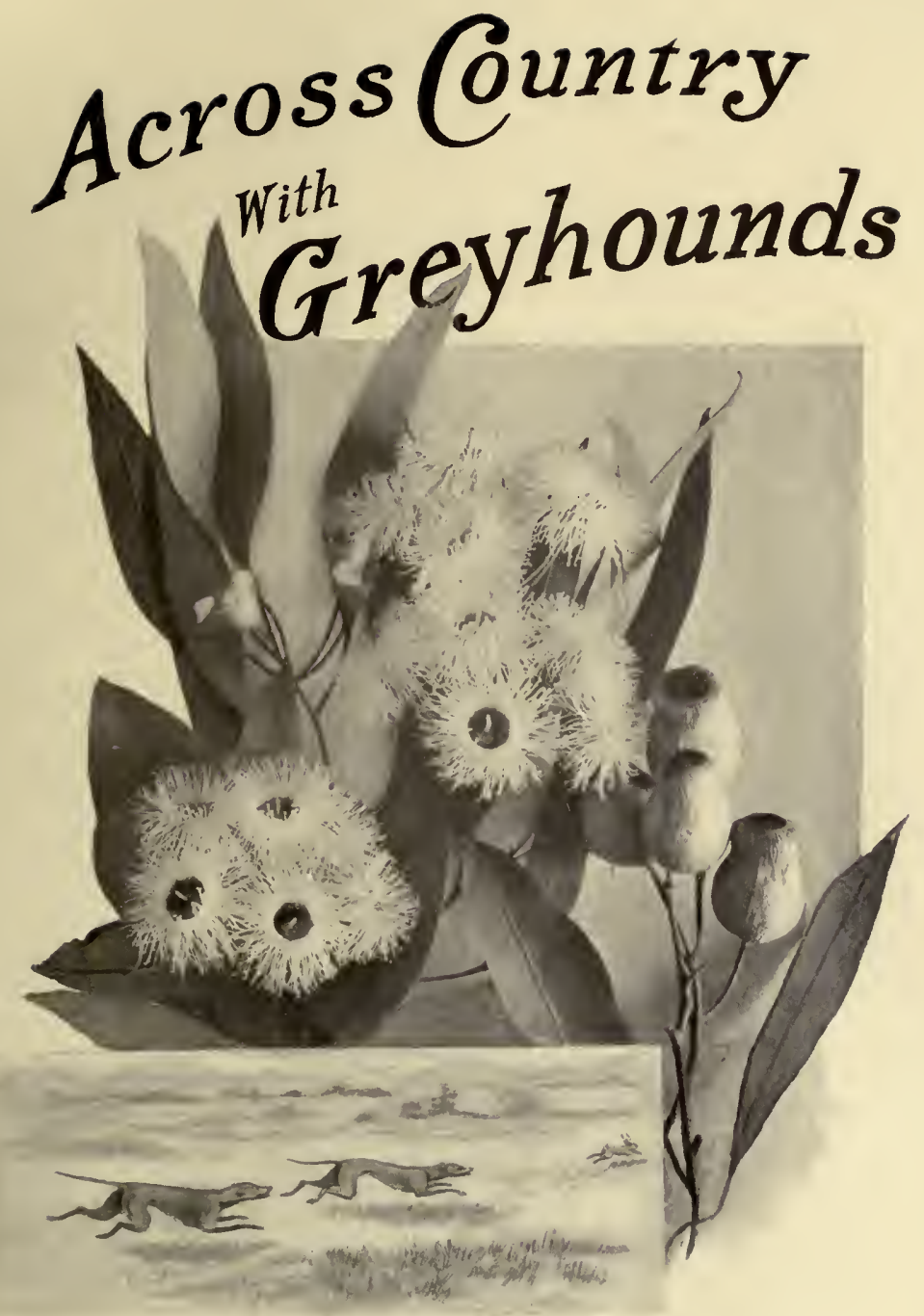





\section{Chapter I}

\section{Across Country with Greyhounds}

$7 \mathrm{HE}$ first rain had come. The mountains were smiling at the distant sea, the air was clear as crystal, and had a rich vibrant quality. The long, feathery lines of white clouds which marked the time of rain had disappeared. No more the dust spout sailed swaggering down along the Puente Hills; instead, processions of geese and cranes flew along the high Sierras, headed to the south. The grey hills were melting into other and deeper tints, and the seeds of alfileria, that had formed a grey mat almost everywhere, were twisting, boring into the ground, and painting the hills, lowlands, and mesa in emerald hues. There was a crispness to the air; every tree and bush was washed clean; the groves of the tall plume-like eucalyptus seemed nearer and greener, and along the highways vivid pink mattings were growing, telling that a marvellous change was imminent. In a word, it was near Christmas time in Southern California, and uncompromising winter, with its roses, its fields of wild flowers, was setting in. 
In the valley, one could hear the clang of bells of the Mission of San Gabriel as they rang out, three miles away, and beyond El Toro, over the divide Don Benito, listen to the chimes of San Juan Capistrano as they chanted to the sea.

On such a morning I came down on to the mesa from Las Cacitas, a spur of the Sierra Madre, where I was living, rode through the deep cañon, whose oaks and bays were dripping with dazzling radiance, and as I came out on to the mesa, from which I could see the islands offshore, fifty miles distant, I heard the tremulous melody of a horn. It came from the direction of Los Robles, and as I rode on through the brush, my horse tossing the odours of sage and other fragrant plants into the air, out from the long lines of eucalyptus trees came the hunt, the horses with their Spanish saddles and fascinating montadúra, and in a blue and tan bunch the dogs, greyhounds of high degree, that had left San Marino an hour or more before.

The country was open for miles near the Sierra Madre, which rose abruptly from the mesa, the land sandy below Las Cacitas, and covered with sage and low chaparral; here an eucalyptus grove, a young olive orchard, and a vineyard, but in the main, open country, so that one could see several miles in almost every direction. This was the home of the jack rabbit or hare, said to be the fastest runner and to possess better staying powers than any animal known, a tree girdler, an enemy of the rancher. Sure of his powers, he lived in 


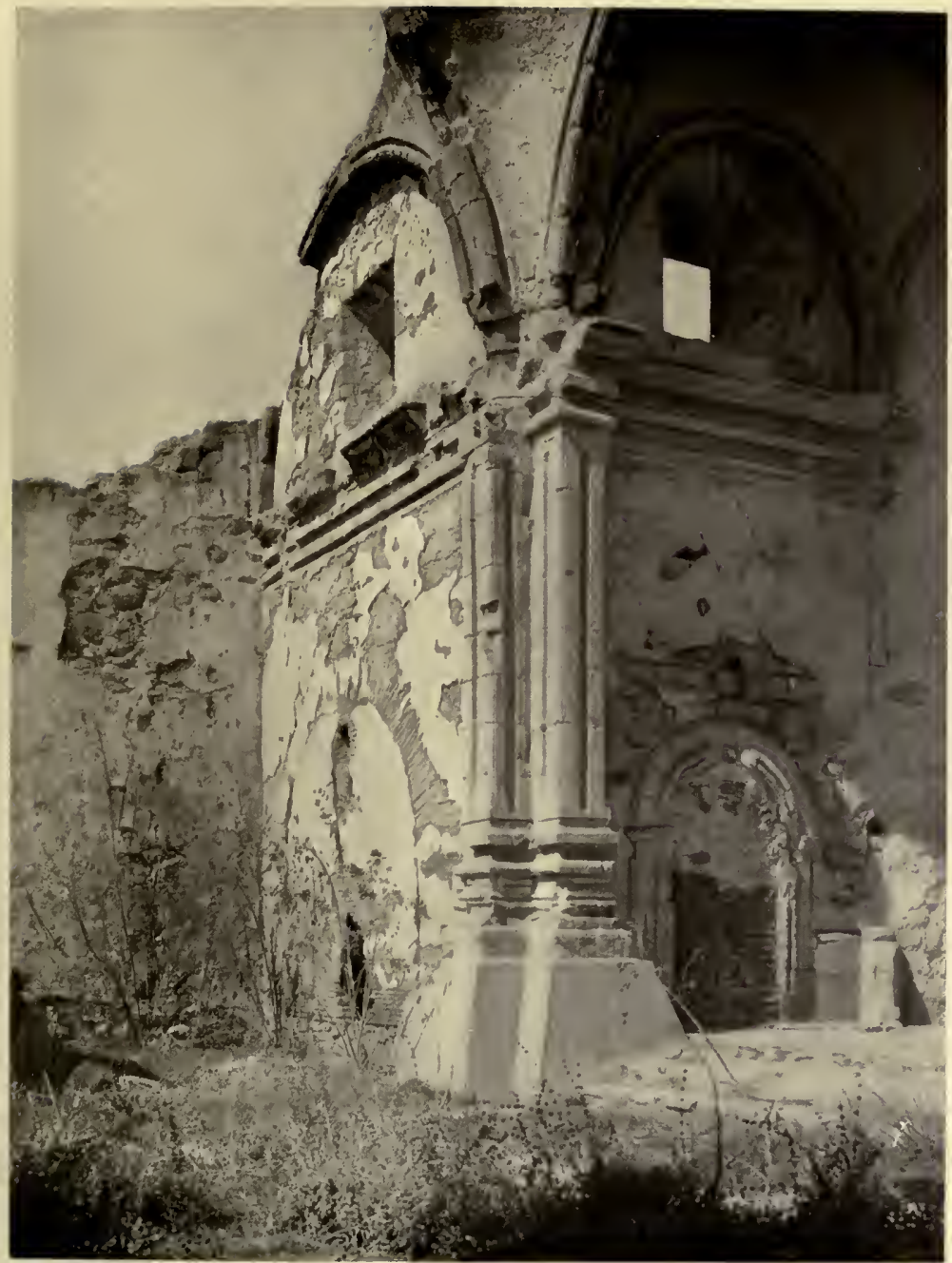

Ruins of the Chapel, Mission of San Juan Capistrano, on El Camino Real. 



\section{Across Country with Greyhounds}

the open, affecting the most barren places. A bit of tar weed or sage was enough for him, and even when chased he despised cover and always turned to the grim mountains and ran up grade, doubtless to wind the horse.

There were twenty or more hunters, all well mounted on wiry fast-running horses, the master of the hounds in the lead behind the dogs. There were greetings, mutual congratulations that you were alive in God's country on such a day, and some men took off their sombreros at the splendid tints and colours of the mountains that, a wall of rock, five or six thousand feet high and forty miles wide, shut out the land and valley from the rest of the world.

The hunt moved slowly along the eucalyptus groves, then at the word turned in, each horse taking a line or avenue, the dogs spreading out. Down the long, leafy parterres you could see blue vistas of sky, catch glimpses of distant mountains, while the air was filled with the aroma of the eucalyptus as the horses' hoofs cut the underbrush.

The plan was to sweep through the grove and drive out any jack that might be lying there. When halfway through, a quick cry from the master of hounds gave the word to the dogs, that dashed ahead, out into the open, twenty yards or so behind a jaunty, fluffy, tall-eared thing that bounded on as though its feet bore rubber cushions, while with a roar of sounds the hunt swept on in a long line at full and splendid speed. 
There is nothing more inspiring than a cavalry charge, and this hunt was a diminutive replica of one. The horses were eager for the chase, knowing well the meaning of the shout, and at once broke into a wild run; and when they cleared the grove the dogs could be seen reaching out in long lines and the bounding jack melting away into space. At this stage of the run he is enjoying himself at our expense. His long ears are up, and as stiff as rods of steel. He runs by bounds and has an air of disdain. The speed is increasing every moment. The master of the hounds by virtue of his office is directly behind them, and after him, never overriding the pack, come the fortunate ones who can keep their place. Already some are left far behind, but a few horses are well to the fore and running at a pace, that considering the country, would bring a cheer from the grandstand at Ascot. The jack runs through a patch of sage-brush, then turns slightly and crosses an orchard, and here is turned cleverly by old Ramon. He runs over a great white wash, bounding down its dangerous sides until it ends, then alarmed by the determined thunder of bounding hoofs, he turns gradually and makes for the upper mesa. Suddenly the master of the hounds shouts a warning. Some turn at the brink of a knife-like cut or wash, ten feet deep, over which the jack goes like a cannon ball. You see that he is taking in sails, is not so disdainful; his ears are lying partly back over his shoulders, and the wonderful hind legs are working quicker and driving him 


\section{Across Country with Greyhounds}

ahead like piston rods. The dogs have lost some time at the turn, and he is two or three hundred feet ahead. Half the horses are out of the game, the wash is a discourager, and two philosophers are walking back, taking the chance of being in at the death in a double; but a small bunch of riders are well in, and riding like the wind. Long ago it was a runaway race; no attempt is made to stop or check the horses; it is their race, and some will not be stopped. The wind cuts the face, and gravel fills the air, picked up by the flying hoofs; while the long lines of blue and grey are creeping up, and on, in a mysterious fashion. Perhaps you are with the master of the hounds in the lead where you can see every move of horse, hound, and game. You watch the marvellous machine just ahead; the dogs shooting forward, then dropping behind. You hear the master of the hounds speak to them; now quickly as the jack runs into the brush, where they lose sight of the game and are at sea. You see them look at him and spring in the air in great steely bounds, glancing quickly around, then, following the direction indicated by his horse, rushing out into the open. The hare is running down a vineyard, doubtless hoping to throw some unfortunate riders on to the black ugly stumps, just leafing out.

But the horses know the place well, and just at the end the dogs close in and turn again, forcing the hare down through the level field. You see him now, not fifty feet ahead; not the jocund tree girdler that bounded out of the eucalyptus grove half an hour before, but 
a long grey object with ears flattened out upon his back - a sure signal of distress - and a certain halting motion that those well in the front take as an indication of a coming trick, a "grandstand play" for which the game is famous, and here it is.

The jack apparently disappears; horses are jerked on to their haunches, a cloud of dust rises, dogs reach out and snap at something as it passes, phantom-like, and you and I and the master of the hounds are away on exactly the back track, and the jack has gained one hundred feet. If you have been at the front you will know what it all means. The jack stopped suddenly, turned about a clump of sage in the open, and dashed back directly beneath the horses' feet. Mouse, my own hound, misses him by the length of a tail, and other hounds snap at him as he goes by, unable to stop themselves, while the clever hare, taking all the chances, dashes beneath the horses, and makes a splendid play for liberty. This turn is shown in the accompanying picture ${ }^{1}$ by Brewer, from a sketch of my own made from memory as I saw the manœuvre, the jack running directly between the feet of my horse, which should be shown nearer in the illustration. It is here that the hunter who has given out and is looking on from some comfortable vantage-ground, often comes into his own without the attendant exertions, as the jack comes back, and possibly is killed in front of him.

In five minutes the horses and riders that have stood 


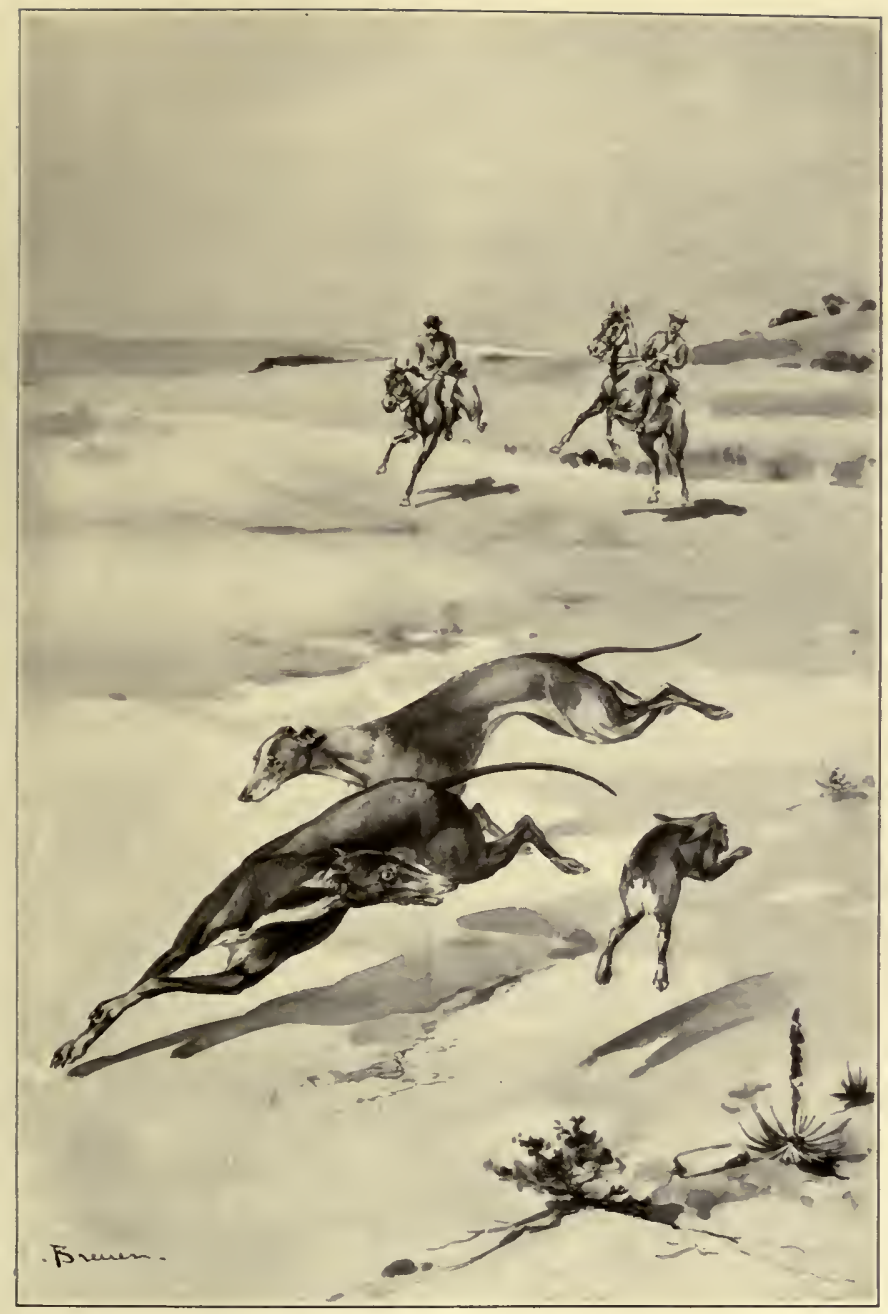

A Sudden Turn observed by the Author. 



\section{Across Country with Greyhounds}

the pace are again surging to the front. The horses are wild with excitement; it is their hunt and they know the finish is near. Several miles have been left behind, and the run has been over unbroken country. Now a blue dog seems to shoot ahead of the jack. $\mathrm{He}$ has been behind all the time, and you have half expected to see him drop out; but Pasqual has come into his second wind and makes a turn that brings a shout from every saddle. "Good Pasqual!" "Bravo, Ramon!" He turns the hare that is met by Mouse; but she misses. There is a flurry, and away down the mesa into a spreading wash they go, over into an orange grove, with a roar of sounds, and the jack in a desperate effort to wind the horses takes the long palm-environed drive toward a ranch house, and like a whirlwind the horses and dogs follow.

The ranch house is straight ahead, and my friend has a long wide hall running through it, for which the jack apparently is headed. I am wondering whether

will object to the hunt running through his home, when out he comes with arms uplifted. He does object, there is no question as to that, but it is the finish. A long, tan-coloured hound shoots ahead, a fluffy hare goes up into the air, and the hounds close around, while one of the hunters in a desperate attempt to stop his horse and keep him from a flower garden goes on, and-tell it not in Gath-lands on his back among the pansies.

It is a famous run. The death or finish was three miles from the start as the crow flies. The dogs are lying 
flat, panting like machines, but happy, delighted, and rolling a glance of congratulation at you, or giving you greeting by a wag of the tail. If they could speak they would all say it was the run of their lives. Along comes the man with a canteen, each dog drinks and its face and mouth are washed, and each master and mistress tells each hound just what he or she thinks, and compliments between man and beast fly thick and fast. The saddles are uncinched, the horses walked up and down and given a drink when cooler. The stragglers have come in, and the hunt, refreshed, stands in the cooling shade of the eucalyptus grove, and discusses the situation.

Such was a typical run with the San Marino or the Valley Hunt hounds of Pasadena; hard, furious, dangerous sport, the hare having an open country and by far the advantage. To ride over such a region with its washes and burrows, the rider took every chance, and the game often escaped; wearing out horse, rider, and hound. There can hardly be any pastime within the realm of sport more exciting than this. It was my fortune to act as master of the hounds in many hunts, and my place was directly behind the dogs, where every move of hound or game could be seen; and as a study of strenuous sport it was without peer; horses and dogs enjoyed it, the jack being the only exception, and he was a pest and menace to the rancher.

The hunt, refreshed, winds out of the grove and turns in the direction of the mountains, following along the slopes. It is midwinter in the East, the whole land 


\section{Across Country with Greyhounds}

is in the grip of ice and snow; but here the air is soft on the cheek, the carol of countless birds fills the air, and drowsy butterflies, yellow and white, are flitting about the fields-harbingers of spring. On one side the wall of the Sierras stands menacing and grim, cut by many cañons, rich in deep greens, that like rivers wind skyward. Near at hand the mountains are grey and green in patches; but as they reach away toward San Antonio they become blue painted with ineffable tints. Ahead the San Rafael Hills rise in velvet mounds, with radiant lights and shades, telling of rippling oats and barley; like great billows they are tumbling on and on to the distant lowlands. To the south but turn the eye, and the green slope of the Sierras is seen reaching the distant sea; a fantasie in colour; squares of green and yellow, blocks of vivid green, mounds of undulating emerald, and beyond the line of silver surf and the blue sea with its caps of islands. A fairer land, a fairer hunting day you will rarely find under this Christmas sun.

Another hare is started and the hunt is again in full run, sweeping up to the foot of the mountains, down into vineyards, where often several jacks are started; but the hounds concentrate their attention on one, and the finish comes up near the entrance to the cañon Las Flores, where the drags, coaches, and carriages have met. Lunch is laid under the trees in some adjacent grove, and the incidents and events of the hunt are again discussed and good dogs are rewarded. Such a hunt well 
illustrates life in the open in Southern California and its possibilities.

Many towns and cities have spread out over the land, and Southern California bids fair to become overcivilised and settled up. But the jack rabbit is not to be crowded out. A wily fellow lives near my home, and I have seen him entertaining himself by leading the dogs down a wide avenue, a fashionable thoroughfare of the town; and in the suburbs he may be always found. This is true of all the foothill cities from Pomona and Ontario to Riverside and Redlands and beyond, while San Diego and Coronado afford excellent fields for this adventurous pastime.

There is also excellent sport to be had on the ranches near Santa Ana and Orange, and in valleys near the San Joaquin, one of the most successful hunts in the history of the Valley Hunt of Pasadena being near Orange, where it was the guest of the Count and Countess von Schmidt.

In the vicinity of Los Angeles the best hunting localities are the San Fernando Valley and the lower reaches and washes of Baldwin's ranch, which may give one an excuse to ride through this splendid domain, with its groves of eucalyptus, orange, and lemon, and its charming vistas of land and laguna. Some of the best hunting I have had in Southern California has been in the southern part of this ranch and near Sunny Slope ranch, where a pack of fine greyhounds is maintained to reduce the tree and vine girdlers; and nearly all 


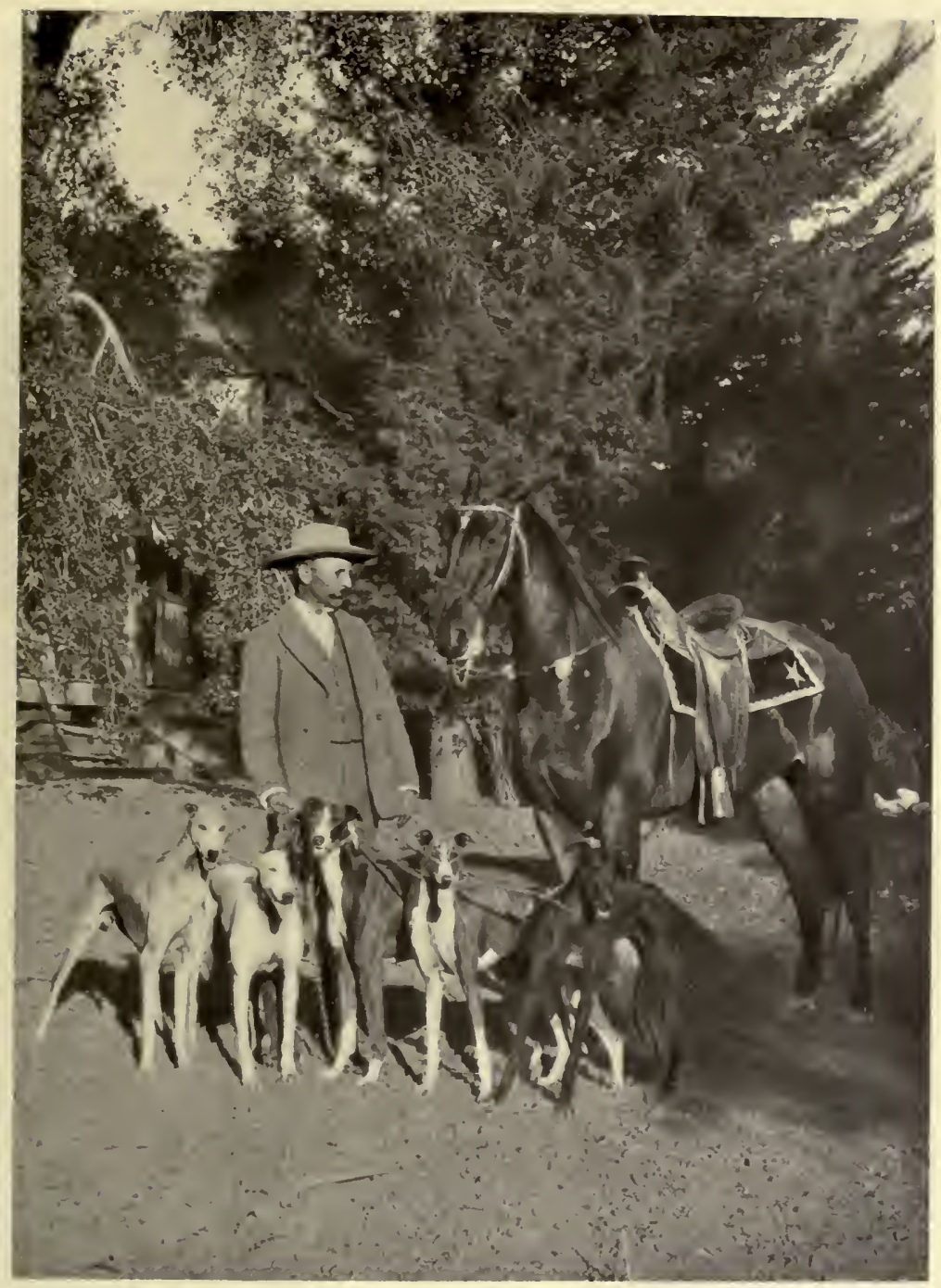

Charles Winston's Sunny Slope Hounds-La Manda. 



\section{Across Country with Greyhounds}

large ranches keep greyhounds to kill off this menace to the crops.

The jack rabbit is a hare, and nests on the surface, rarely if ever taking to burrows or anything of the kind. He prefers to run in the open, to dodge behind hedges and trees. For many years I hunted with my own dogs, and, when President of the Valley Hunt, often acted as master of the hounds, when it was my duty to keep up with the pack and direct it on the runs; consequently I had many opportunities to watch the dogs and game in all stages of the chase. The Valley Hunt pack of ten or fifteen hounds was in charge of a huntsman or keeper, and generally there were two masters of hounds, members of the club, who took charge of the dogs on a hunt, and went with them, a hard riding position. Courtesy required that the hunt should not pass him; indeed, it was the duty of the one in charge to see that excited members did not override the hounds. The hunt could keep as near the master of the hounds as it could get, but could not pass. When the game reached cover, he had to keep the jack in sight, and see that the dogs obeyed his call; and so well did the hounds understand this, that often they would not lose a foot, though they lost sight of the game for several minutes. A greyhound named "Mouse" would, in high grass, leap on to my horse behind my saddle, and, with one arm over her, I would ride slowly along. When a hare was started she would see it, note its direction, leap down, and rarely miss it. It is sometimes said 
that greyhounds lack intelligence and affection, but never was there a greater mistake. A good greyhound is one of the best of dogs, of aristocratic mien, a type of strength, power, and staying qualities, with a love for hunting, cleanly, beautiful, and affectionate.

The jack will often nonplus a very clever dog. I once made a long run nearly to the mountains, and when at the upper rise of the mesa, horse, dog, and hare began to give out. After a while we came down to a trot, then to a walk, and the jack, apparently scarcely able to move, ran to a big fir tree, and around it several times, chased by the hound, that was so desperately winded that she could not catch the jack. I reined in my horse, not twenty feet distant, and watched the absurd denoniment, laughing heartily at my dog Mouse, a very clever animal. She soon became dizzy and stopped running, then walked uncertainly over to me in a most shamefaced manner and sat on her haunches, while the jack faced us for a second in sheer amazement. He had doubtless been the hero of numerous chases and was bewildered, but the dog and I agreed that he had earned his liberty, and we sat and watched him limp away into the chaparral.

Such sport as this is not to be confused with " coursing"-a cowardly, brutal game that cannot hold its own in any country among gentlemen. The hare is released in an enclosure and chased by hounds, with no possible chance of escape; while in the open, in a fair chase across country, the chances are against the rider, 


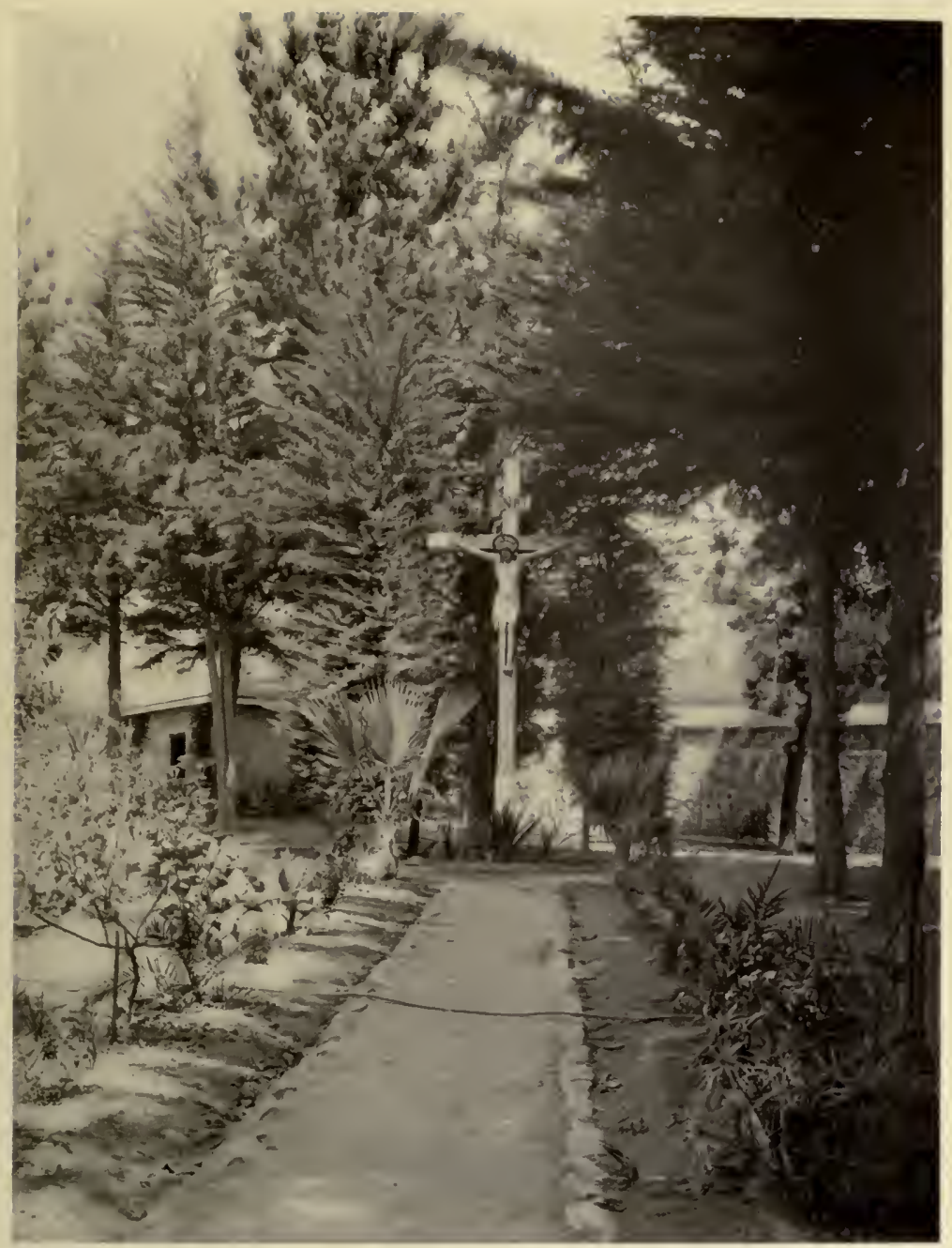

Walk at the Mission of Santa Barbara on. El Camino Real. 



\section{Across Country with Greyhounds}

and the tree girdler has every opportunity to escape, as where horses are in trouble he flies over the ground like a bird and often lives to run another day.

The hunt breakfast ends, the well-rested horses and hounds walk slowly down the valley again, on the lookout for game, the carriages and drags following, stopping here and there to see the exciting runs; and late in the afternoon, perhaps, the hunt winds down the long sweeping mesa, headed for home, that may be ten miles away, if the run has led them down to the Baldwin wash, or it may be but a mile; but no matter where, the weary riders have the panorama of the hills as inspiration. As the sun sinks behind the western peaks of the Coast Range, a splendid transformation scene is staged on slope and mesa. The tips of the Sierras are wreathed with light, and out from each cañon and gulch dark shadows creep, encroaching slowly on the fields of yellow and gold. Slowly the hills take on a roseate hue that grows in intensity and splendour as the sun drops into the sea. Deeper it becomes; now crimson, then scarlet, a gorgeous drapery that slowly fades and melts into purple until the entire range, except where the snow-caps of San Antonio are bathed in the fiery glow, is invested with the deep panoply of night.

From down the valley, filtering through the windbreaks of eucalpytus trees, comes softly on the wind the flute-like tremulo of the horn-the adios of the huntsman and his hounds. 



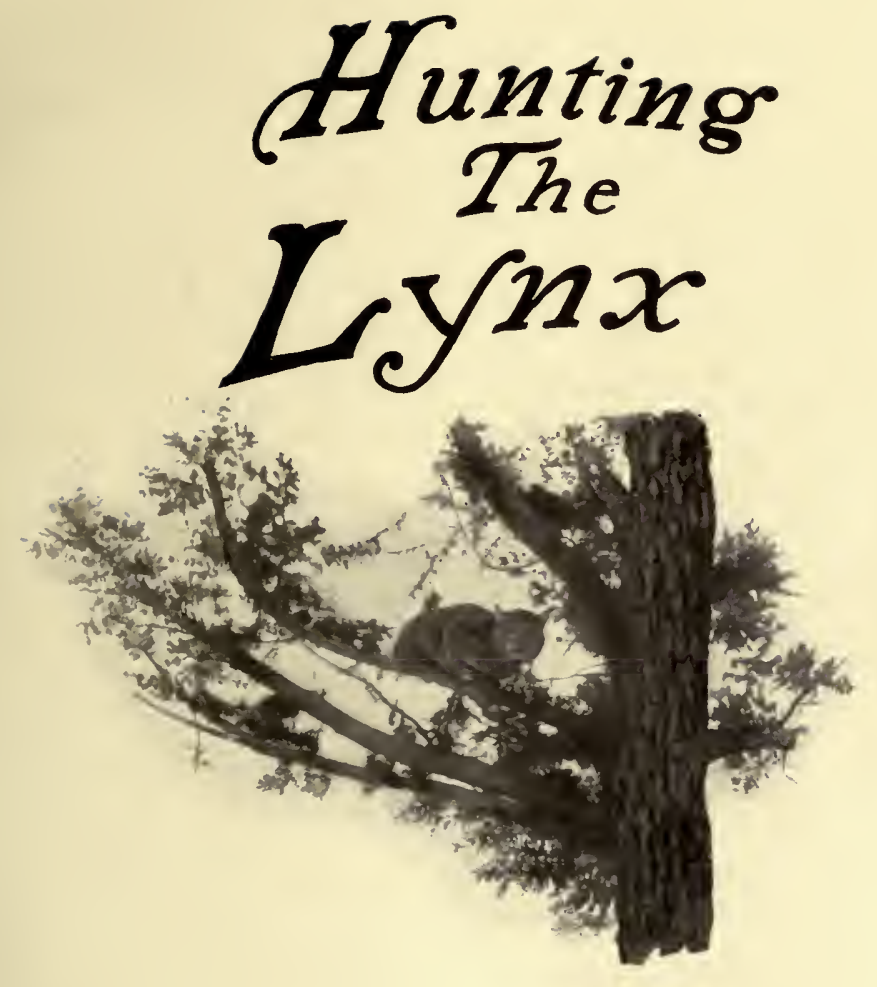




\section{Chapter II}

\section{Hunting the Lynx}

$\mathrm{O}$

NE of the charms of Southern California lies in the fact that the towns and many cities are within a stone's throw of the open country, or the mountains. Los Angeles is but thirteen miles from the main range of the Sierra Madre, a jumble of mountains so steep and forbidding that trained mountaineers have been confused by their precipitous cañons and sharp divides. There is hardly a village, town, or city where wild country is not available in some form in a short distance. The stroller up the east branch of the Los Angeles River, the Arroyo Seco, is led by agreeable paths on this winter day into a cañon, down which a small stream flows, now on the surface, again sinking beneath it, flowing on and on to the distant sea. Here it has high banks, and has cut into a series of hills that are a blaze of yellow, carpeted with a small daisy-like flower. Everywhere the river-bed is filled with polished stones, and along the banks patches of silver foxtail grass nod in the sunlight, and in the shallows windrows of mica gleam in lines of gold. 
The hills grow higher. Here they are undermined, the talus partly covered by masses of wild oat whose surface ripples in catspaws in changing tints of green. Along the low left bank are lavender flashes among the rocks, telling of the wild pea, while the yellow glow of the primrose and the blue of the larkspur are caught against the green of the chaparral. Soon the arroyo widens, and live oaks are seen in a little basin. The sullen roar of the city is still heard, but the sky is bright, the sweet song of birds fills the air. Surely it is not February along this verdant arroyo? You may climb the hill and look out over distant fields of rippling grain and a marvellous coat of green that robes the land from mountains to the sea. Winter it is, fair and uncompromising, permitting flowers, soft air, and clear skies. Not the winter of the tropics, hot and enervating, but a winter of content, crisp, with just a soupçon of frost in the early morning to make the scent good and clear.

The scent, ah! that is what you are after. Are you not on horseback? and there, standing under the oaks, is Don A - with his famous foxhounds, Melody, Music, and others, and coming down the road are other hunters and the hounds of the Valley Hunt.

The meet is at the cienaga, and it is proposed to work the green hills to the east and south for the lynx, common game in Southern California, game that uses the big arroyo and washes as highways from the mountains. All the hunters are mounted, and Don A- 


\section{Hunting the Lynx}

sounds his silver-throated horn, calls in the straying dogs, and outlines the plan of action. A few hunters are to go around the hill with the hounds, the rest are to remain in the arroyo and keep the game within bounds. You elect to go, and, making a long detour, climb the slopes, the hounds entering the hills. Already Music has the scent, and the blood-stirring melody, like nothing else in the world, comes rippling through the air, $\mathrm{O}-0.0-0$, and is taken up by Melody, who is standing looking at the scenery for a second, then she sends the news down to the hunters below that not many hours before a soft velvet-footed lynx passed that way from some looting, and is not so far away.

Again comes the baying of the hounds, pouring over the hill and dropping into the little cañada, to be taken up by others. The hilltops here, six or eight hundred feet above the sea, one hundred or more above the arroyo, form a spur of the Sierra Madre, that reaches down toward Los Angeles and to the east, merging into the Puente Hills, a splendid winter highway for game where there is cover, and for coyotes at any time. On the surface were disconnected bunches of low brush, giving the slopes a park-like effect, and farther on groves of white oak with spreading branches beneath which nodded the shooting-star, the mariposa lily and the graceful stalks of Brodæa.

Into this garden of the hills the hounds ran just ahead of my horse, following the scent, now and then baying soft and low, working through the tall grass 
until they came to the oaks, when Music gave the signal and the entire pack broke into the volume of sounds that tells of fresh scent. Few horses with a drop of sporting blood in their veins can resist the sound, and mine reared, plunged, and pawed the air in eagerness to run; but the hounds had not found the game, and I followed slowly while they made the welkin ring. I could hear the answering baying from over the cliff in the arroyo as I rode into the oak grove, then over the divide to the south slope.

The hounds were now running at full speed, past the cactus patches, along rocky slopes, down into a deep cañon where the baying broke into a roar, and then over the edge of the arroyo a fourth of a mile above, where my horse, settling down upon his haunches, slid down with the miniature avalanche, then running down-stream at full speed to find the hounds out on the face of a cliff crawling along on narrow ledges, slipping and rolling, while in the very centre of the stage, in full sight, was the lynx. She appeared to ignore the hounds, stopping now and then to glance behind, then picking her way along, step by step, looking down at the horses, again stopping to weigh the chances of the situation.

It seemed impossible for a dog to reach her, but Don $\mathrm{A}-$ and I knew that Music was a sort of canine fly, and he quickly gave a vivid demonstration of it, crawling out on the trail of the big cat, now perfectly silent, while other dogs made the arroyo ring with sounds. The lynx was surrounded. She faced a dog in front, 


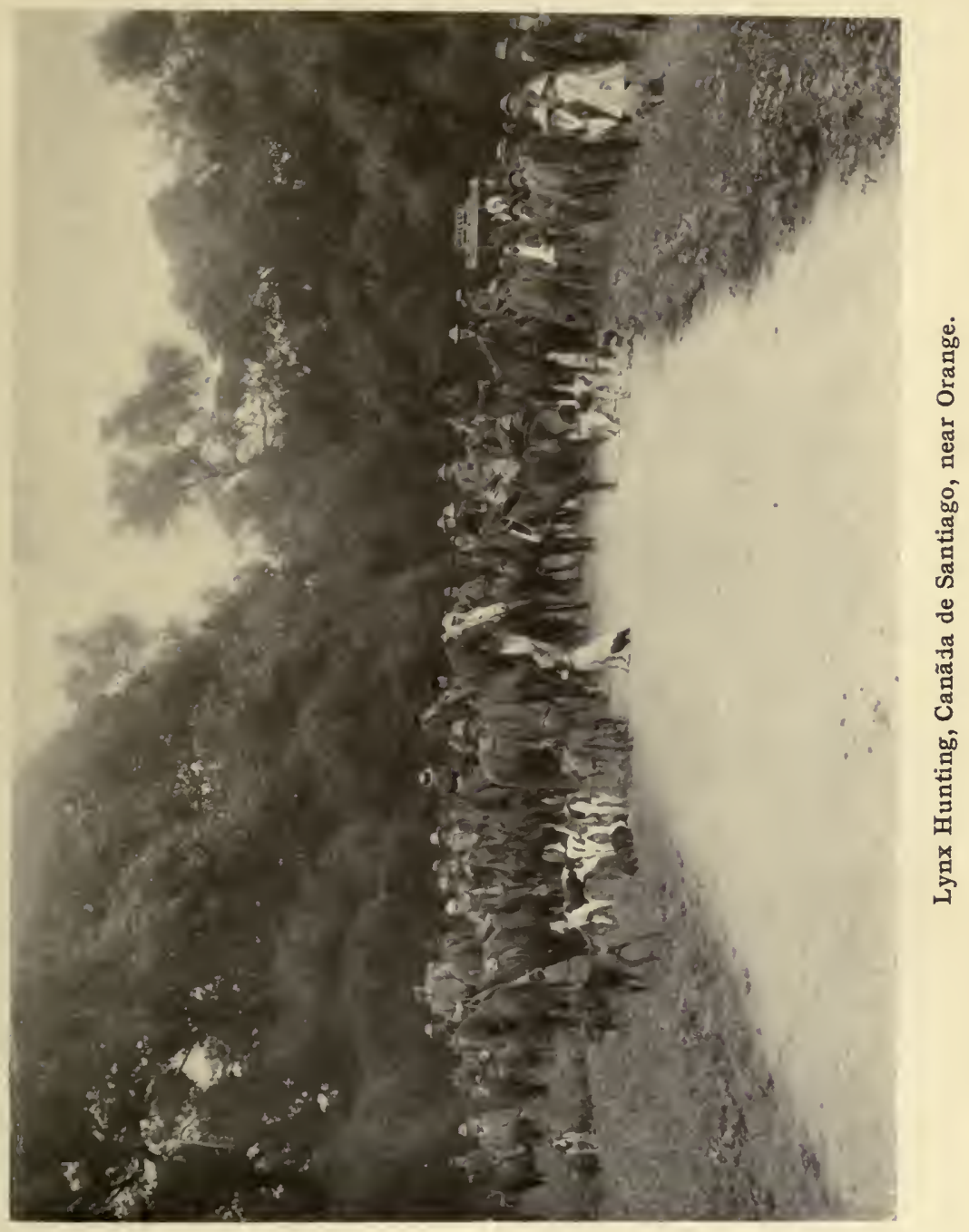





\section{Hunting the Lynx}

others were above and behind, and the hunt stood in the stream, one hundred feet below. There was wagering among the lookers-on as to what she would do, but she quickly decided it. Music reached within ten feet of her short tail, when she turned and came down the face of the cliff like a rubber ball, bounding from rock to rock, and when within a few feet of the bottom with a savage front sprang fairly into the pack and horses.

It was a brave and clever trick, as a dozen jaws snapped at her, but when she struck the rock she seemed to bound into the air, and dashed among the feet of plunging horses, making a run of perhaps one hundred yards, and when the hunt recovered from its surprise she was sitting in the top of a large oak, her eyes gleaming fire, her short tail twitching, treed, but not caught, and around the trunk gathered the pack baying, filling the air with what were now menacing sounds. The trunk of the tree stood at an angle, and Ranger, an old tree-climber, was presently fifteen feet up and out on a linb, from which he had to be helped down. Some of these dogs were marvellous tree-climbers, but even a dog is helpless where he can fall.

I hauled myself from the saddle into the tree and climbed slowly upward. The lynx did not move until I had reached a point within twenty feet of her, where I sat a moment and looked her over. She was a miniature lynx, with small tufted ears, a rich spotted coat, and pronounced reddish "whiskers." The head was large, 
and the eyes, which looked into mine, blazed with the same yellow light you may see in the glance of the black leopard.

When I made an offensive movement, she stood up, showing the long, powerful legs and the short tail, which was twitching from side to side in a significant fashion. I climbed higher and thrust a branch at her, whereupon she darted out on to a limb, and with one glance and snarl at me, went crashing down through the resilient screen of green into the pack.

When I dropped on to my horse again, the hunt was sweeping up the arroyo and through the chaparral ; coming to a cliff the lynx clambered up the side, but was again driven out, two dogs rolling down forty or more feet, then forced across the stream and treed in a dense patch of brush, into which the infuriated hounds vainly essayed to climb.

From here she was finally dislodged, and in making the leap she missed me by a very few inches. I had dismounted and was holding my horse when I saw her coming by my head, literally dropping out of the sky, four paws out; when she struck she bounded upward like a ball, and the pack literally fell over me in their attempts to reach her. But some miraculous dodging power aided the tribe, as she again eluded them, and was treed after a hard run through the chaparral, from which she ran down through an arcade of wild grape vines and reached the hills again, where she threw the dogs off. A long stretch of country was scoured before 


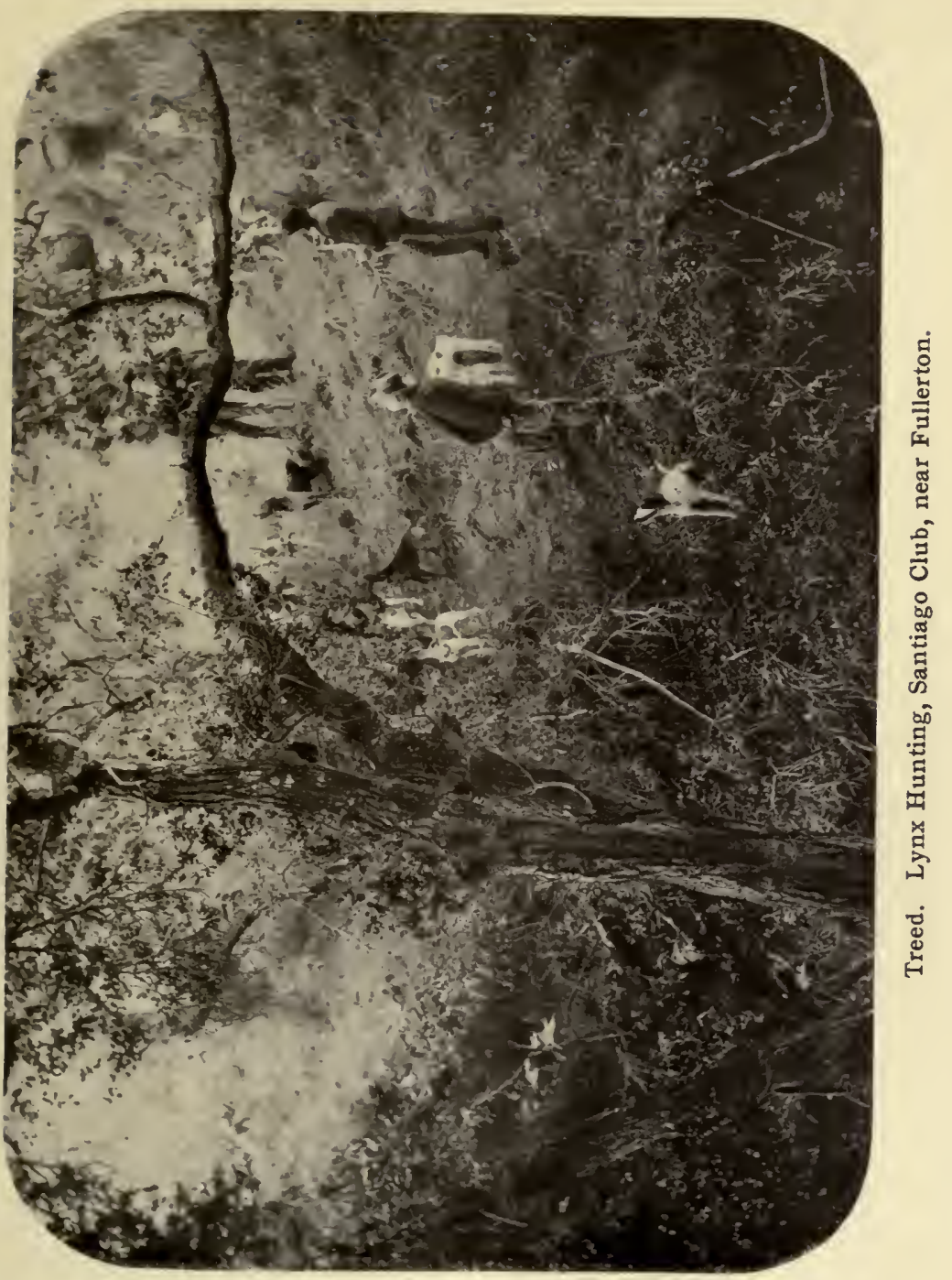



the scent was picked up, and after another run the game was treed in a large sycamore.

Two hours had slipped by, and the excitement and speed of the runs had told on the dogs, which were yelping with rage and disappointment. They now ran about the tree baying in ominous tones, their tongues hanging out, and the long mournful $0-0-0-0,0-0-0-0$, rising on the air like the tolling of bells. $U p$ into the tree went another hunter, and the hunt backed off to give the animal fair play, that was the essence of the sport. She waited until he reached her, snarling at him viciously, then creeping out on to the tip of a limb, glanced about, and made one of the pluckiest jumps I have ever seen or heard of, going down clear forty or fifty feet, bounding on her rubber-like pads several feet into the air, then fighting her way through the dogs, cutting as she went. She ran fifty feet on the level, when Music shot ahead and rolled her over, and bedlam broke loose as the pack poured in. At least half the hounds were cut or slashed by this vicious animal that fought with tooth and claw, throwing herself upon her back, and snarling like a fiend. Several dogs were retired before she succumbed. Hanging from my saddle she nearly touched the ground, a fine specimen of lynx, in good condition. On her skin, which I had mounted as a rug, various young hounds were introduced to their first game, and it is fair to say that they ultimately wore out the rug in these practice hunts.

The hunt now worked up the arroyo beyond the 
town of Garvanza, eight miles from Los Angeles, and entered a well-wooded pass, where the dogs took a scent and ran a mile along the San Rafael Hills. The scent grew fresher, until finally a roar of sounds indicated something brought to bay at the foot of a giant sycamore in an almost impenetrable jungle of scrub oak, tall briar rose, and other brush. Using my heavy crop I broke a way in, to find one of the dogs wedged in a hole, surrounded by others who were so crazed by the proximity of the game that they fell all over me. I managed to seize the hound by the hind legs and pull him out by main force, and with him came, not a lynx, but a raccoon, which had seized the hound by the paw and held on with the grip of a bulldog, held on until I pulled it completely out, and the dogs fell upon it.

The arroyo was from fifty to one hundred feet deep here, its sides precipitous, filled with underbrush and large trees; sycamores and black oaks growing on the banks, cottonwoods, alders, and others in the centre and on the sides, with little meadows here and there above the stream. The wild grape had climbed many of the trees and interlaced them in a radiant drapery of green, forming a natural jungle for the wildcat, raccoon, and fox. The hounds presently caught a scent, and after a short run treed a large lynx, a process that was repeated half a score of times before she was finally captured, proving a most gamy animal.

The Arroyo Seco, a river of verdure if not water, reaching down from the mountains, is a natural park, 


\section{Hunting the Lynx}

the gulch forming the western boundary of Pasadena. As I write, two minutes' walk from its fragrant edge, over which I can see the tops of its trees from my lawn, I hear the melody of a hound calling, O-O-o-o, telling me that somewhere in its green heart the foot-cushions of a lynx have left their imprint on the yielding sand. I sometimes go down in the afternoon and smooth it over in the middle of the moist stream-bed, then visit it in the morning to read the story. Here are quail tracks, the long foot of a cottontail, the sinuous trail of a snail, the big print of a dog-some hound hunting for pleasure,and the round footprint of the lynx, with that of a raccoon or possibly a fox. Indeed, the casual stroller through this green arroyo in winter might never see an animal larger than a quail or rabbit, yet the sandy trails tell of a diversity of game that walks abroad o' nights or comes down the dry green river from the mountains to visit the haunts of man.

Nearly every cañon in Southern California has its quota of lynxes, generally of two kinds. Those leading from the main range are most frequented, but in nearly every arroyo of any size where there is underbrush and trees there will be found the gamy and savage enemy of the rancher.

All along the Sierra Madre, from San Luis Obispo to San Diego, the sport may be had, and several wellknown packs of hounds are kept in California-notably the Kentucky pack of thoroughbreds of Mr. William G. Burns, of the Pasadena Country Club. These hounds 
are trained to drag-hunting as well, and have made some spirited runs over the beautiful country at the head of the San Gabriel Valley. There are two or three small packs of hounds in and about Pasadena; one in the vicinity of the San Fernando Valley, and perhaps the best and largest in the Santiago Cañon, a valley to the south of the San Gabriel, reaching down to the sea. Here, extending out from the foothills which constitute a sort of coast range ten or fifteen miles from it, some of the finest lynx or wild cat hunting in California is found. The country is beautifully situated, being in the main a splendid oak park with a series of well-wooded cañons. Nearly all are occupied by ranchers, and well up Santiago Cañon is the attractive mountain home of Mr. J. E. Pleasants, Master of Hounds of the Santiago Hunt Club of Orange, whose hospitality and meets are well known.

This club has hunted the country nine or ten years, and game, fox, coyote, and lynx, is so plentiful that there is constant exercise for the pack. The dogs, Trilby, Don, Pluto, Mack, Diana, Flash, and many more, are from Southern stock, recruited from Virginia, Kentucky, Georgia, and Alabama, and some of them, owned by the hunt and Dr. Page of Pasadena, are remarkable hunters. The master of the hounds lives up the cañon twenty miles from the city of Santa Ana, and twice a year, in May and October, special hunts are enjoyed that have a wide reputation. They are held in Orange County Park, a fine piece of well-wooded country about 


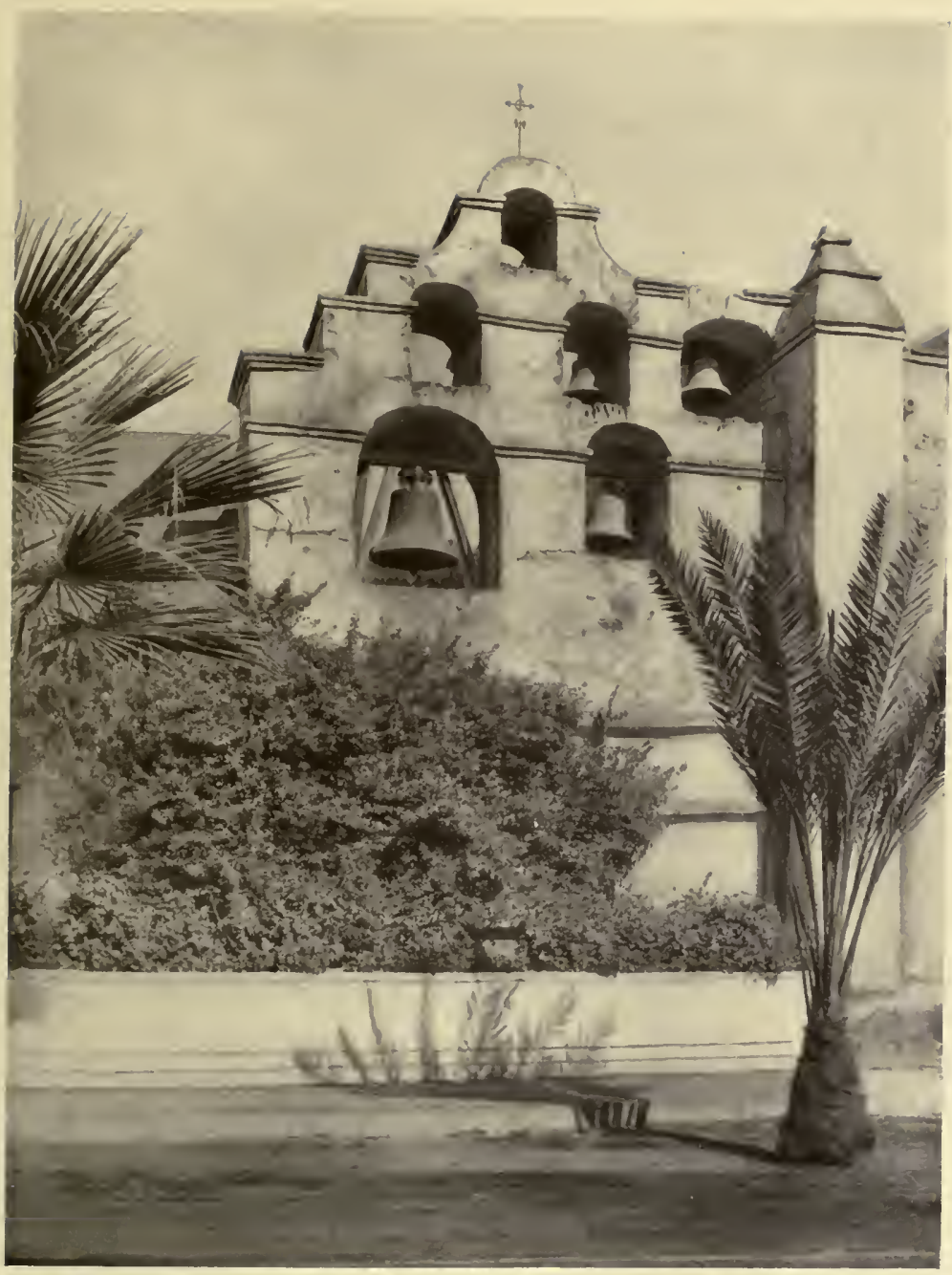

The Bells of Mission San Gabriel Arcangel near Pasadena. 



\section{Hunting the Lynx}

ten miles from Santa Ana and stretching along the south face of the foothills. Several hundred people attend them, and go in conveyances of all kinds, and with tents camp out in the grove, forming a small village. Famous cooks, the Serranos, are on hand, and after the hunt there is a barbecue, Mexican fashion, where chili con carne, chilicolorado, tomales, and tortillas are served, and if the hunter is not fired by the hunt he is by the feast that savours of the days of Lucullus. It is worth a trip to California to see Señor Serrano and his brother barbecue a steer, and toss or turn the meat with a pitchfork by the light of the moon as it pours down through the great black live oaks.

The hunts average twenty lynxes and fifteen foxes a year, and in the driest weather the hounds have no difficulty in taking the foxes. These meets are looked forward to with pleasure and delight, and in the gloom of the live-oak forests one meets many famous Californians and lovers of sport, none of whom are more enthusiastic than Dr. Benjamin Page, who can tell you every hound by his voice and the exact stage of the game, just as he knows the highest peaks of the Sierras, the deepest cañons, and all the famous trout pools of Southern California along the high Sierras as they overlook the great desert of the south. It is good to see the old-time hunting gentleman imparting his enthusiasm to the younger generation and handing it down as a legacy.

The Southern California lynx, Lynx rufus, is a handsome spotted animal, weighing sometimes fifty 
pounds; there are two distinct forms here recognised by hunters. I have seen a large lynx, a tall, longlegged, scrawny creature, that could run like a deer and was treed with difficulty. It had tassels to its ears, and the fur on its cheeks was very long or pronounced, while another has more the appearance of a large, overgrown domestic cat, yet with tassels and beard.

The red lynx, Lynx rufus, is found across the continent to California and into Texas. It has short reddish hair, while the spotted lynx, a larger form, has a striking spotted coat, and ranges all through Southern California and down into Mexico. This lynx is a powerful and savage animal. I have seen one for a few moments fight off a pack of hounds, lacerating them badly; and when I saw one coming from a tree in my direction I always gave it the right of way. They are very uncertain game; no rule can be applied to them. Some tree repeatedly, and I have worked nearly half a day on a lynx in an oak grove, the animal repeatedly ascending trees and refusing to run. Again in the same Cañada Valley I have seen a large lynx leap from an oak and deliberately take to the open in a long run of marvellous speed.

The Valley Hunt Club of Pasadena maintained a pack of greyhounds and a pack of foxhounds for many years, the latter being used for lynx-hunting almost exclusively, not being fast enough to run down a coyote in the open country. The pack was a gift of Dr. F. F. Rowland, who brought them to California from the Rose Tree Hunt of 


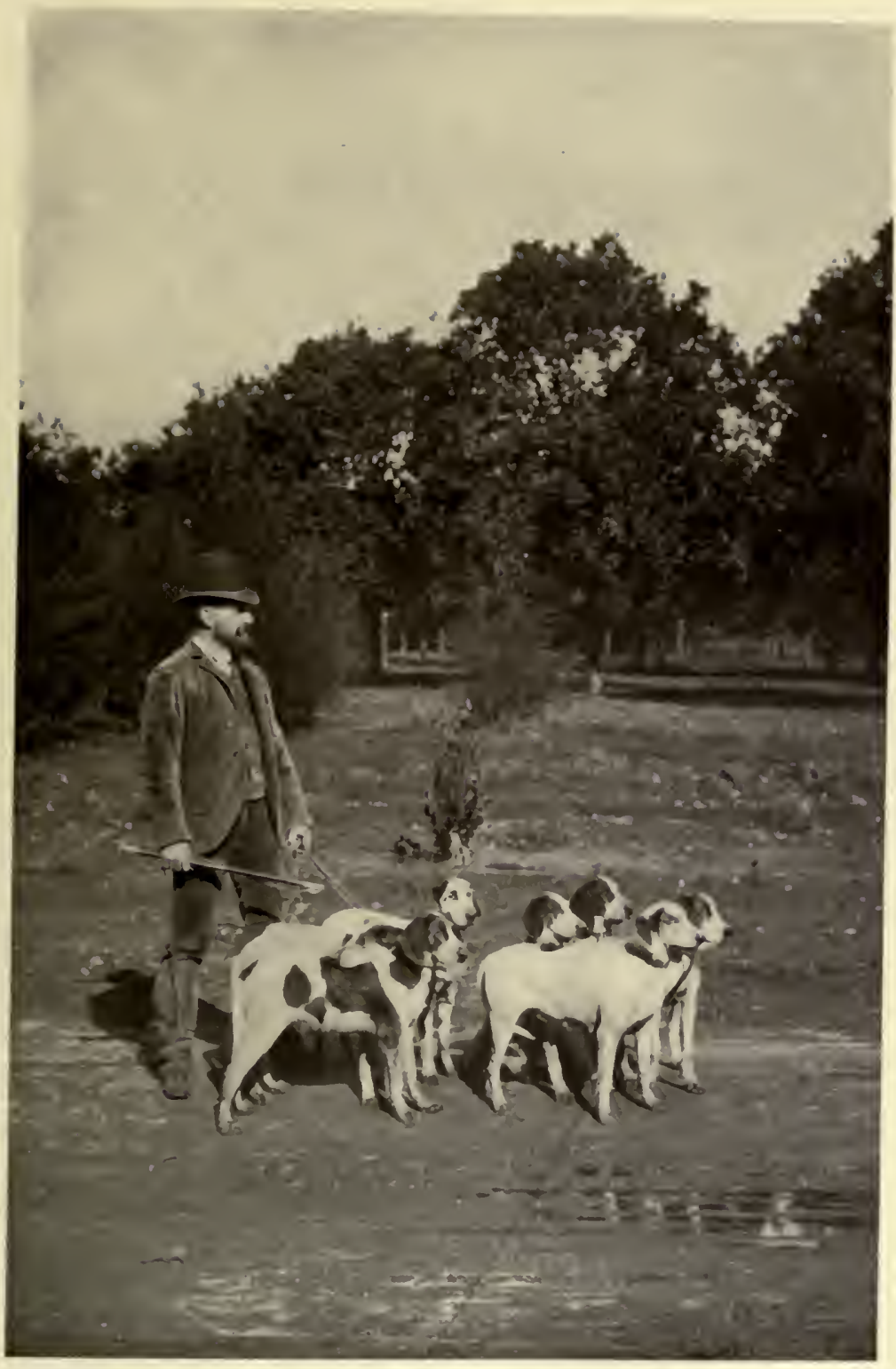

Valley Hunt Foxhounds, Pasadena. 



\section{Hunting the Lynx}

Pennsylvania. I hunted the hounds about twice a week with a friend, and as they did not have sufficient exercise our experiences became a part of the history and traditions of the club, often at our expense. We invariably ran down game. If it were not a coyote, fox, or wildcat, it would be a Chinaman, a burro, or a dog. These hounds would have something, and when we started out or entered a town, every living thing took to the woods. One day we were moving through one of the cañons of the Puente range, about seven miles from home, when we came upon a herd of sheep on the crest of a hill. The hounds had drawn a blank, and when one sighted a sheep he ran it down, possibly mistaking it for a coyote; at least we claimed this for the hound. But before we could reach it the pack had killed the sheep, which rolled down the hill. Presently the herder, a piratical-looking Basque, appeared, headed for us, and we prepared for trouble, as a matter of precaution keeping our horses above him, as he came stalking along. We braced ourselves for the explanation and were ready to apologise and settle, when the man came up and taking off his hat said in a Basque patois, "Will the gentlemen pardon my fool sheep? They run and excite the hound. I am very sorry"; then he waited and-well, we accepted his apology with dignity, and, of course, insisted upon paying for the sheep.

Another day the pack took up a scent and with a roar of sounds swept over the mesa like the wind. 
There was no telling what the game was, but after a long run we went through the main street of a little village like a whirlwind. An incautious Newfoundland dog came out of a German's yard, followed by his master, to see what it all meant, and the strenuous Valley Hunt hounds fell upon him. The German doubtless thought he had been attacked by wolves as he fled, and the scene of action was changed to his house and piazza. We threw ourselves from our horses and rushed into the mélée, my companion to save the German and I to intervene with the hounds with my crop on the part of the Newfoundland. It was one of those experiences which drop out of clear skies upon peaceful lovers of nature-a rude blast on an otherwise peaceful sea. It took fifteen minutes to convince those hounds that the German gentleman was not some kind of game, and that they believed the big dog to be a bear there could be no question.

Having succeeded in driving the pack out of the little garden, now a wreck, I began to think of escape, but it was an evil day. Our horses had run away and there was nothing to do but face the irate German, who stated that he had a brother-in-law who was in some way related to the Lieutenant-Governor of California, and the latter was to be summoned at once. It was fortunate that in those Arcadian days telephones had not disturbed the peace of suburban communities, or we should doubtless have been held and hauled before this official. As it was we faced the irate citizen, and in a 


\section{Hunting the Lynx}

short time the entire village gathered. There was but one thing to do. We were in the enemy's country, the situation required quick action; we decided on that foundation of all American diplomacy, a bluff. Calling aside the German's wife, a ponderous but amiable lady, I confided to her that her husband, was liable to get into serious trouble. He had insulted my friend, who held a very high office in the neighbouring city. Her husband had allowed his big Newfoundland to attack Herr - 's hounds and had led them into her house; did he do it to obtain possession of the hounds or what? I stated the case strongly, dwelling upon the grossness of the insult to my friend and through him to the city he lived in, ending the peroration by expressing the hope that her husband would not have any serious trouble.

The lady appeared dumbfounded at this phase of the question, as well she might, and I saw that my argument had produced an effect, the lady was anxious to consult her excited husband. But he was being interviewed by my companion, who told him that it was unfortunate that he had seen fit to attack a man so prominent as his friend, Herr School Trustee, a high educational official under the municipal government of a neighbouring city, and he wished it understood that he would not be responsible for anything that should happen to a man who used decoy dogs to attract visiting hunts. This convincing logic came in the nature of a shock to the German, and he no longer quoted the 
classics or referred to the Lieutenant-Governor, retiring with his wife to the house for a conference, while we, having hired a boy to follow the horses, stood as models of outraged dignity.

American diplomacy succeeded. The worthy couple soon appeared ; the husband said he had misunderstood the situation, and begged the gentlemen to overlook it. The gentlemen thus appealed to took it under advisement and finally concluded to accept the apology on account of the lady. Thus was the incident closed. The boys brought our horses, the German gentleman and his wife bowed low over the wreck of their hollyhocks, the prominent city officials gave a profound salute, the boys, having been tipped, raised a cheer, and the Valley Hunt rode proudly down the long country road in the direction of San Gabriel.

Below the mission was a vast vineyard, and beyond were fields of nodding grain that rippled and laughed in the sun as the wind caressed its surface. Then there were great open stretches covered with alfileria, and along the sides of the road were lines of wild oats, the yellow violet, and little blue cup-like flowers, while in the fields grew masses of wild daisies of a score of kinds, the plume-like painter's brush, the yellow mimulus, and over them, like the background of a Japanese picture, towered a mountain of snow, a silver liberty cap, a California Fuji-yama ten thousand feet in air.

Near here the hounds gave tongue, the baying in- 


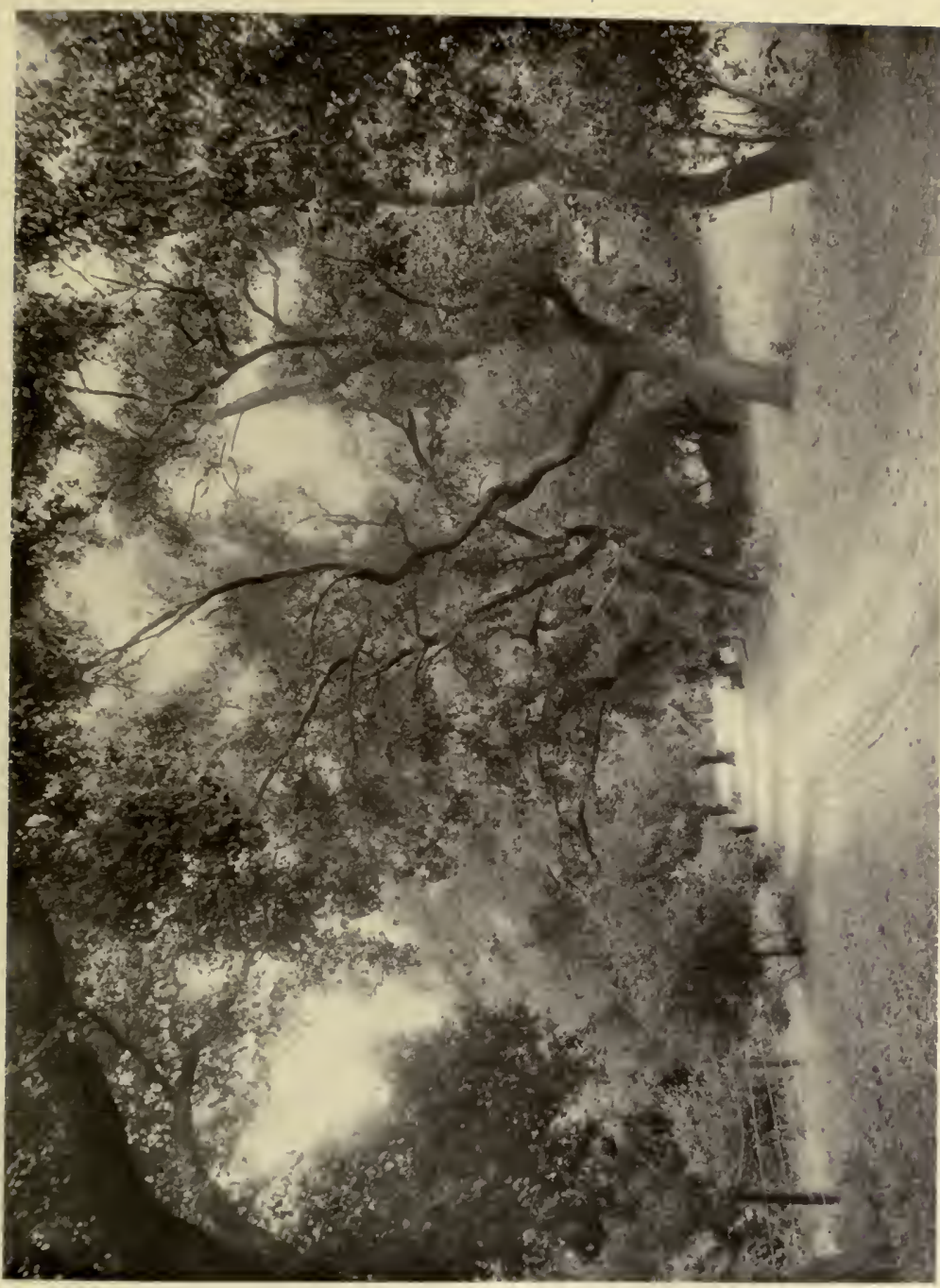

 



\section{Hunting the Lynx}

creased, and we forgot our troubles in the cheering, tremulous music, the rolling, deep-throated soundsO-O-0-0-0-0-that have a direct appeal to the man who is susceptible to such influences. It is a language, this baying, a language of tones and inflections, and any lover of foxhounds will translate it for you. There is a cry of anticipation, another when a light scent is picked up, another when it deepens, still another when the game is near, and when it is sighted-and who can mistake that splendid booming tone that tells the hunt that the game is treed! Then when a lynx makes the mad jump and the hounds miss it and are running, how easily understood by the rider far away!

All these variants in the language of the hunt were heard by us, and as the pace grew fiercer, the cries wilder, we closed in and swung into a field and at full speed ran at a mammoth pile of brush, reined up amid a cloud of dust, and swung ourselves from the saddle, to confront-ministers of grace defend us!-a huge pig with a large and interesting family. She did not even rise ; she merely grunted, while our eyes wandered over the astonished pack and conjured up wild schemes of revenge.

It must not be thought that the hounds were useless ; quite the contrary, they were not exercised sufficiently and literally went wild when we took them out. No better dogs ever took the trail of a fox or wildcat, but when not worked they insisted upon divers diversions, and they had them at our expense. It was uncertain 
pastime. One day we had invited a party from Los Angeles to meet us midway between the two cities. The keeper of the hounds threw open the corral, which was on the arroyo road, and the pack took a trail at that spot and, in full cry, started for the arroyo. The bank here was one hundred feet up and down. I believe the pack went over it, and we slid down a small path and followed. Once I heard the echo of a bay several miles to the south; later in the day I heard it somewhere to the west, and two days later a letter came from a rancher up the San Fernando Valley, twenty miles away, to the effect that the Valley Hunt hounds had just passed; did we want them ?

The days with these hounds in the deep arroyo, or in the open, in the floral winters, despite their occasional vagaries, are among the pleasant memories of the earlier California days, and there are still Newfoundland dogs, wildcats, lynxs, hounds, and, above all, winters when the palm leaves rustle in the soft wind, and petal snowflakes drop from the orange, lemon, and lime. 


\section{DeerFunting in the \\ SouthernSierras}

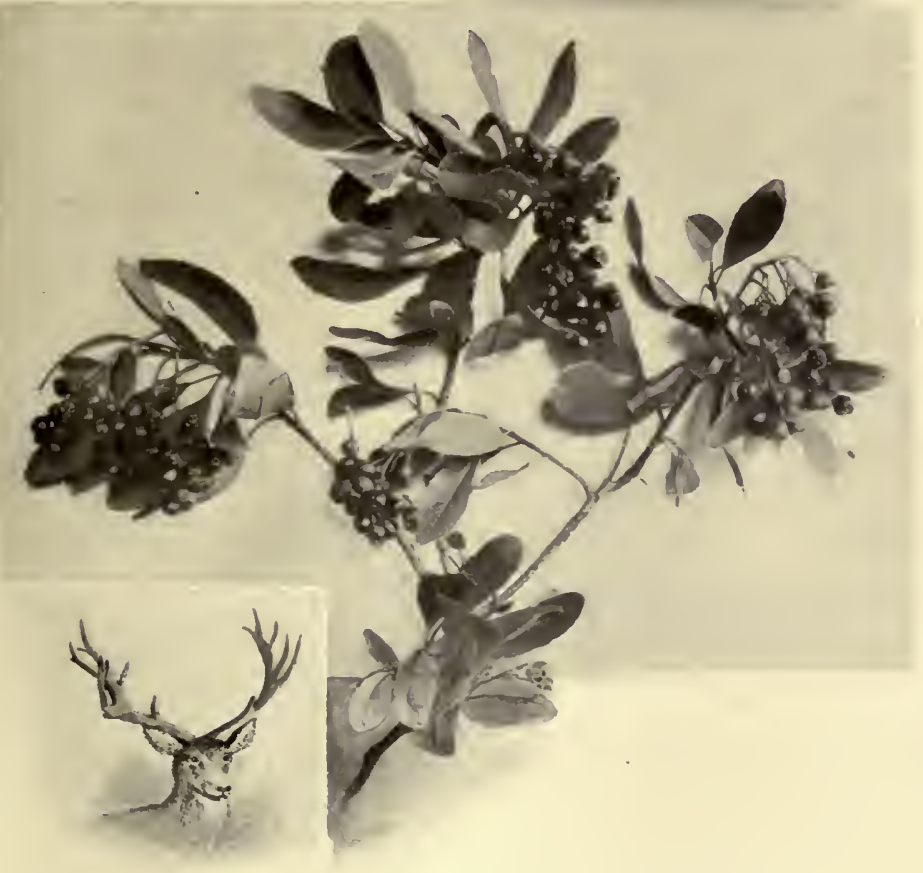





\section{Chapter III}

\section{Deer-Hunting in the Southern Sierras}

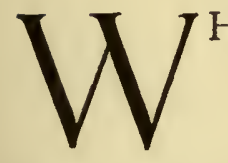

HEN living on the immediate slope of the Sierra Madre, I was within rifle-shot of three cañons down which tumbled the waters from the upper range. Sometimes the water ran under leafy arcades where the fragrant bay quivered in the soft wind, then out into the open, above which the dark blue of the larkspur stood out in relief against the green of nodding brakes, then gliding down the face of some green slide where dainty maidenhair and other ferns trembled in the rush of air. Then the water would gurgle and leap through polished rocks, dart out into the open again, and swing merrily along, bearing freight of acorns, pine needles, oak leaves, or a branch of trailing vetch to strand them on a mimic bar of shining sands.

These sand-bars were found everywhere in the arroyo. I established relations with and consulted them as to the coming and going of the forest animals, and if word had been left me, the message could not have 
been plainer. Here was the soft footprint of a wildcat, the dainty trail of a snail; here a cottontail had crossed at full speed, and, deep in the yielding sand, the hoofprints of the black-tailed deer. He had cooled his hoofs in the stream, then started back to drier ground, where, with ears alert, he stood listening. It did not require a mystic to translate the story of the footprints in the sand that perhaps were effaced by the night's rain, or by the rising of the stream-a dreamer of dreams could read it.

Several times, in wading down the stream, looking through some leafy covert, I came upon a deer, and sometimes in the fall, along the unfrequented slopes, one would be seen in the blue haze of early morning. During the hot day he has been lying on the summit of the range in some little clearing, or on the north and cool slopes; but in the cool evening or morning he is abroad, pushing through the chaparral, showering himself 'with crystal drops, sniffing at the perfumed panicles of the wild lilac, and nipping the green tips of the Adenostoma.

Down he comes, crossing the divide, looking out into the valley filled with silvery fog, through which the tops of hills emerge like islands. He brushes aside the trumpets of the mountain mimulus, starts at the murmur of the deep-toned pines, stands and listens until the mimic echo of the sea dies away, then pushes out into the stream and takes the trail along whose sides grow the viands of his choice. He nibbles at the wild honey- 


\section{Deer-Hunting in Southern Sierras}

suckle as it falls over the scrub oak, stops at the tall arrow grasses, thrusts aside the wild sunflowers, and leaps from the rocky pass into the open where the arroyo ends. He may wander down the stream, or perhaps climb up the sides and stroll out on to the west mesa, hiding in the little washes where the wild rose fills the air with perfume, feeding here and there as his fancy dictates.

At such times I have seen him, when the eastern sky was ablush with vivid tints, the snow-caps of San Antonio suffused with the golden light of the coming day. You look twice and again, so well does he match the chaparral, so harmonious the tint; indeed no one would suspect that this placid-faced, large-eyed creature standing like a statue, big in the haze, was a grape-eater, that he had pillaged the ranch below Las Cacitas the night before, and the one before that had played havoc in a Cañada ranch. But it is the same, and you have laid in the chaparral waiting for him night after night, and now he is gone, and off somewhere with lowered head he creeps through the bush and makes good his escape.

All the ranges of the southern Sierras abound in the black-tailed deer; an attractive creature, at the present time difficult to shoot if fair play is given. Indeed, I can conceive no more difficult sport than to hunt the deer in the Sierra Madre without dogs. The extraordinary character of the mountains, the steepness and depth of the cañons soon tire out the hunter. I had hunted deer in the Adirondacks, in Virginia and Florida, 
following them over the country, and my first effort along this line in Southern California demonstrated that for me at least, where deer were not very common, the sport merged into work of the most arduous nature, and after that I hunted deer with hounds, skirting the slopes of mountains, using the dogs to start them in the lower cañons but not to run them down.

A single hunt may illustrate the arduous nature of the sport if followed with enthusiasm. By sunrise we were riding down the Cañada between the Sierra Madre and the San Rafael Hills, the road lying between the ridges in the centre of a wide valley. It was September, the last of the long summer. The alfileria that swept along the valley in the early spring, clothing it with green, was dead, and the open country bore a brown and burnt-umber shade. The vineyards, orange and lemon trees were green, but the tall mustard stalks that had been laden with gold, the clovers and others were dead, and their tones and shades combined with the barren spots in rich neutral tints. The sun was just rising, the ranges were clothed in purple hues, and far to the east a scarlet alpine glow appeared growing and spreading over the world. The deep shadows crept out of the cañons, the divides became more pronounced, the distant ranges assumed deeper blues, and finally the big trees that fringed the summits were silhouetted against the blue sky as the sun climbed up out of the desert and looked down on California.

We drove through a long line of ranches for five 


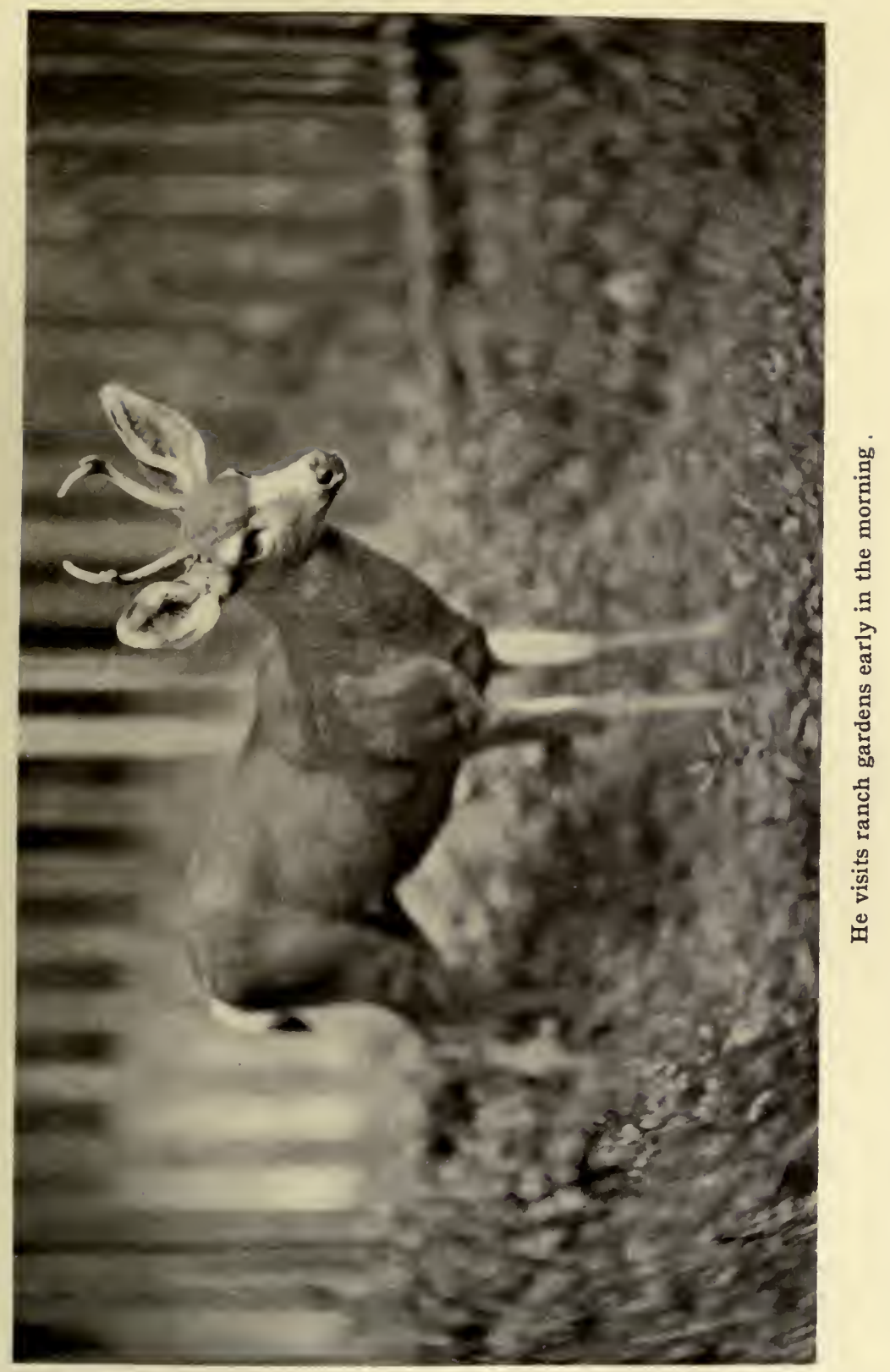





\section{Deer-Hunting in Southern Sierras}

miles, turned to the south into a narrow green cañon, then wheeled sharply to the right, and up among the cactus and chaparral of a little valley pulled up beneath the live oaks. The hounds jumped out, my guide unharnessed, fastening one horse to the tree and saddling the other for my benefit, and we started up the cañon.

I thought of my last deer hunt not a mile from $\mathrm{Ned}$ Buntline's old home in the open at the foot of Blue Mountain in the Adirondacks, where I stole through the forest over a bed of leaves, resting on fern-covered trunks coated with moss, every leaf, twig, and branch scintillating with moisture. Here the only dampness for six months had been the fog and dew ; not a drop of rain had fallen, yet the chaparral that robed the mountain was rich in greens, a mantle undulating and beautiful, at a distance, but, to hunt deer in, an impenetrable maze.

This chaparral was composed of Adenostoma, a thick, sweet-scented bush from four to six feet high, spreading and stiff, so that when it bent back and struck one on the return, it was a flagellation. With it were masses of Heteromales covered with white flowers, sumac, wild lilac, scrub oak, and others, with here and there in the clear places a Spanish bayonet or yucca with a thousand daggers en guard. Imagine acres of this, bound together in a more or less compact tangle, with patches of dead wood, remains of ancient fires, which were stiffer and more offensive than the rest.

My guide said there was a trail, and leading the way 
I followed the path, so called by courtesy. There had been one, but the chaparral had closed in upon it like the waves of a sea, and in ten minutes my faithful and well-trained horse was butting through and I was swept off and carried away. I then took the animal by the tail and fell into his wake, and so we literally butted up the side of the mountain several hundred feet until the semblance of a trail became more evident, when I again mounted. We were on the side of a deep and well wooded cañon, a vast basin of green without a break, reaching up to the summit nearly four thousand feet. Already I could see over the hills and look down into the San Gabriel Valley, while the back and distant peaks of the Sierras began to unfold and range into line.

My guide now took the hounds down the slopes and began to work up the cañon, while I kept along the trail, that was a mere depression in the chaparral. Out of the gulf of green now came the splendid baying of a hound, a bay of inquiry, answered presently by another not far distant, taken up by still another, and far below me I could see the low chaparral waving as they worked along. I gradually moved upward; now skirting the cañon and where occasion offered making a zigzag climb; now going ahead to break down the lilac brush or to push the greasewood aside for my patient horse, then climbing into the big Mexican saddle to sit, rifle over the pommel, and watch in silence for a deer.

Again came the flute-like baying, growing in intensity until there was a continuous volley of sounds which re- 


\section{Deer-Hunting in Southern Sierras}

verberated from side to side of the cañon, arousing all its dormant echoes. The hounds had passed me, so I plunged into the chaparral, reaching an open place near the summit as they came up the slope. There they missed the scent and swept down again, and I worked my way upward to a spur near the peak where I seemed to be above the very world. Away to the south was the Pacific like a mass of cloud. I could see the long line of surf, the islands twenty miles out to sea, fifty miles distant, like some huge monsters. Occasionally I heard the baying, and dismounting lay in the bush and looked down into the matchless abyss watching for the game. An hour later I saw it across the cañon, about the size of a large dog, too far away it seemed. But I fired and repeated the shot several times, emptying the magazine, as a flash of dun dashed along the side of the cañon; then my guide appeared on a lower grade, plunging down the side of the mountain, breaking through the chaparral, and later I saw him climbing up the opposite side, from which he brought the deer.

It was high noon and the summer sun beat fiercely down, while we ate jerked venison, and waited for the afternoon; then we changed to another peak, seeing deer but getting none, though on a steep slope I came upon a fine buck that doubtless had been shot and lost some days previous. If there had been no game, there would have been the view. The San Fernando Valley was at my feet with its shimmering sands, its scattering masses of chaparral, and winding through it the white, 
silvery bed of the Los Angeles River, while beyond rose the Sierra Santa Monica range reaching away, literally plunging into the distant Pacific. One must climb to such a height to appreciate the mountains of Southern California and obtain an intimate glance of the land.

It is a good principle and safe in such hunting to keep to the trails. Led by exuberant fancy and a desire to see other parts of the mountains I rode down a long limb of the mountain over a coyote trail, in a short time finding myself involved in the chaparral. If I could have gone down on my knees and crawled I might have made some progress, but the breaking through was deadly. I came out into an area that had been burned over, and as my horse pushed aside the branches they sprang back like steel springs. For a time I was seriously involved and came out, as General Gordon has expressed it, "worn to a frazzle," having learned the lesson to keep to the trails and not attempt in summer to ride a horse through the chaparral on the south side of a Southern California mountain that has been burned over.

There are mountains back of Santa Barbara and in San Diego and other counties where deer-hunting is not so difficult, where the game is more plentiful and can be followed in the Eastern fashion. Again, in some of the less frequented regions it can be found in the lowlands along the base of the mountains, especially over the line in Lower California; but some of the finest sport can be had in season on the great slopes of San Jacinto, 


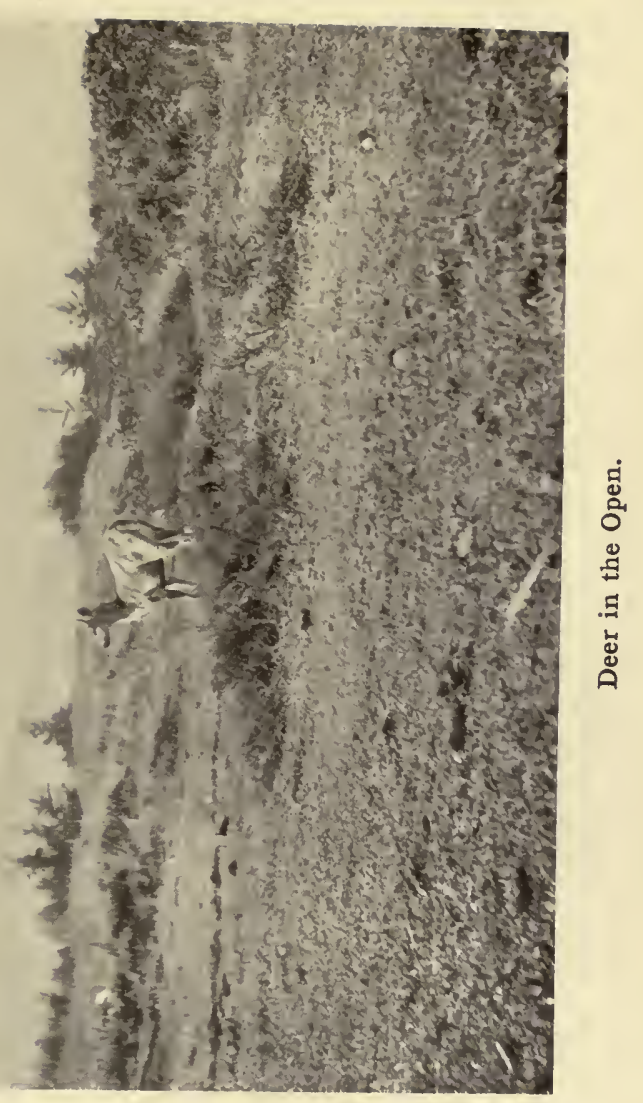





\section{Deer-Hunting in the Southern Sierras}

San Gorgonio, San Bernardino, and others. At Bear Valley there are long stretches of park-land and forest five or six thousand feet above the sea, where the country is more or less open and level, presenting an inviting prospect to the deer hunter.

No Eastern sportsman should go on a deer hunt on the south side of a California range in summer without a competent guide and a thorough understanding of the country and the conditions. I have known men who had hunted deer in the East for years to come to grief not ten miles from Los Angeles. They became involved in the hot, stifling chaparral, and were rescued on the slopes of steep cañons with difficulty. In all the towns which stand on the foothills skilled deer hunters can be found, and if sport is to be had they should be employed. Again, the Sierra Madre are dangerous to inexperienced men. They appear smiling and beautiful in the cañons, but they abound in steep precipices and are often cov. ered with a mass of brush or chaparral that is most difficult to penetrate, wearing and deadly to the man who is lost and confused. The entire range abounds in large safe cañons and trails, but the inexperienced sportsman, the "tenderfoot" who attempts to cross the range as he might the Adirondacks, or any Eastern range, by going directly ahead, up and down, will soon come to grief. The moral, then, is to go well equipped, with some one familiar with the mountains, and if this is not possible, keep to the big cañon trails. 



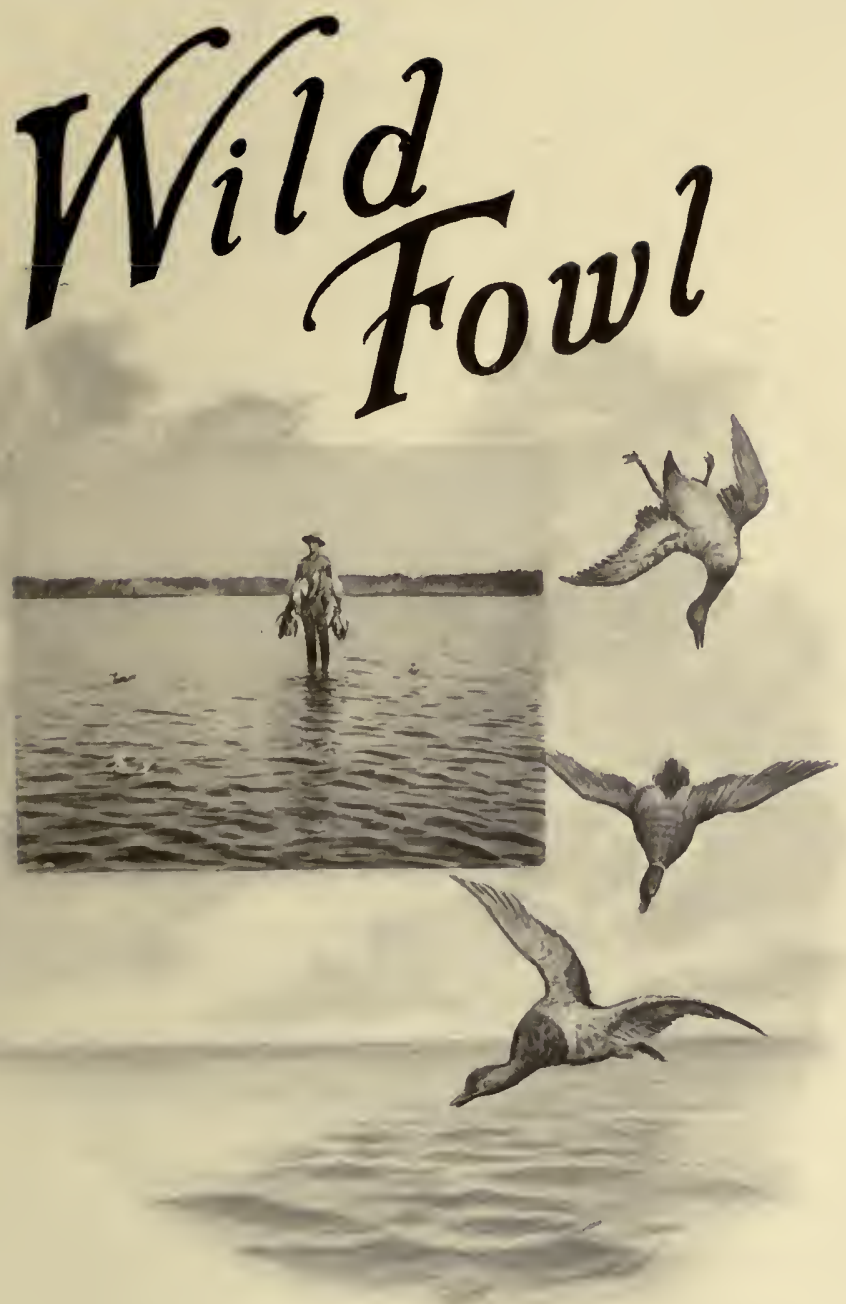





\section{Chapter IV}

\section{Water Fowl}

$7 \mathrm{HE}$ coast of Southern California is, in the main, a long stretch of sand dunes changing every

1 hour and moment in the wind that heaps them up into strange and fascinating shapes. In many instances they form breakwaters, damming up the waters that flow down the cañons' stream-beds from the interior. Thus all the country to the south of the Palos Verde, near San Pedro, and extending to Long Beach, is a shallow back bay, a series of lagunas or canals, often running back into the country to form some little pond or lake.

At Alamitos, where the San Gabriel River reaches the sea, and at Balsa Chica, one of the finest preserves and clubs in the country, and other places along shore to San Diego we shall find these lagunas, or sea swamps, the home of the duck, goose, and swan. The season begins in November, and if there has been an early rain the country is green and beautiful. The long summer is a vanishing memory; the air is clear, and the distant 
mountains stand out with marvellous distinctness; the days are shorter, there is a crispness to the air, and the mountains-what tints of blue, what ineffable shades, suggestions, and tones of this splendid colour! The main range is of turquoise, of old India mines; the second, lapis lazuli; the third is the tone I have seen in labradorite; then the spur farther still is azure; but here your blues give out and fail, as have the greens long ago. Suddenly one day there comes from somewhere over your head or high in air wild and vociferous sounds, and leaping out into the open every vagrant fog fleck seems to have given tongue, and a great, white aërial maelstrom is forming before your eyes. Around it whirls, rising upward; now dazzling the eye with glittering silver, as though some prodigal hand had tossed newly minted dollars into the air, then disappearing to come again; flashing, scintillating against the blue of the heavens. $U p$ it rises; then a single goose, almost reaching the empyrean, turns, followed by the flock, which lengthens out into a long angle and sails, slides down-hill along the face of the Sierras-a token by which you know that ducks, geese, and cranes are going south and that winter and the shooting season has arrived. No more beautiful sight than this can be seen in Southern California when these vast flocks pass up and down, silhouetted against the chaparral of the mountain slopes.

If you live in the mountains this call comes every few hours. Near my camp, on a spur of the Sierras, in 


\section{Water Fowl}

October I could hear geese and cranes many times a day; sometimes so near that they were killed by rifleshots; again half a mile in air, coming down the aërial toboggan slide of Southern California, their habit being when they reach a point too low for safety to stop and, with vociferous cries, whirl about, climbing the air as described, and then, on reaching a high altitude, soaring, not flying, away to the south along the mountains, in this way covering four or five, possibly ten miles, when another break occurs and they climb again.

In this way the geese and cranes migrate to Southern California. At this time the oranges are turning to gold; the land that was brown and grey is green; the Heteromeles flashes scarlet on the slopes of the cañon down which you pass, and the lowlands, where the wild rose garlands some little runaway through the hills, are rich in sweet odours. Then, from high in the air, comes the honk, honk, honk of the wild goose, and you are away to some little laguna you know well, far down by the sea.

There I found myself one morning before daylight sitting in the barrel blind on the edge of the laguna, with decoys all about, and the air filled with the gutterals of swamp birds and the cries of myriads of blackbirds. The high fog was going out to sea, and away to the north was seen the long line of the Sierras, the tall peaks, as San Antonio, standing out like sentinels, while to the west rose a wall of green weed, its tall spikes reflected in the water in lines of vivid colour, bending here 
and there under scores of blackbirds. It may be my imagination, but if there is not organisation of some kind among these birds, the imitation is perfect. I had my decoys well placed, and was out of sight before a bird left the weeds where they spent the night, but the first glimpse of the sun started them, and a roar of sounds filled the vibrant air. They thronged the bending reeds and, suddenly silenced, a flock of four or five hundred rose, as though by concert, and flew away; then bedlam broke loose again-ping zeee ee ping zeeee, and countless sounds,-followed by silence, when a new army would rise. For an hour I watched these delegations leaving, each going in some different direction, thus dividing up the great blackbird army; some flying to one ranch, some to another. This lot perhaps selected Balsa Chica, the next the San Joaquin, another the Aliso, and so on until quiet settled down over the laguna, and the coots and rails had the field to themselves.

If one does not bag his ducks or geese there are the charms of the swamp, the variety of animal life, the strange sounds to listen to-all compensations. But what is this, far to the south where the laguna reaches away to the sand dunes and sea? Several black spots appear, standing out with vivid distinctness. On they come, now resolving into birds-ducks coming in from the sea perhaps, to feed on wild celery, grain, alfileria, and the choice grasses that carpet the soft adobe down to the edge of the water. They are coming directly 


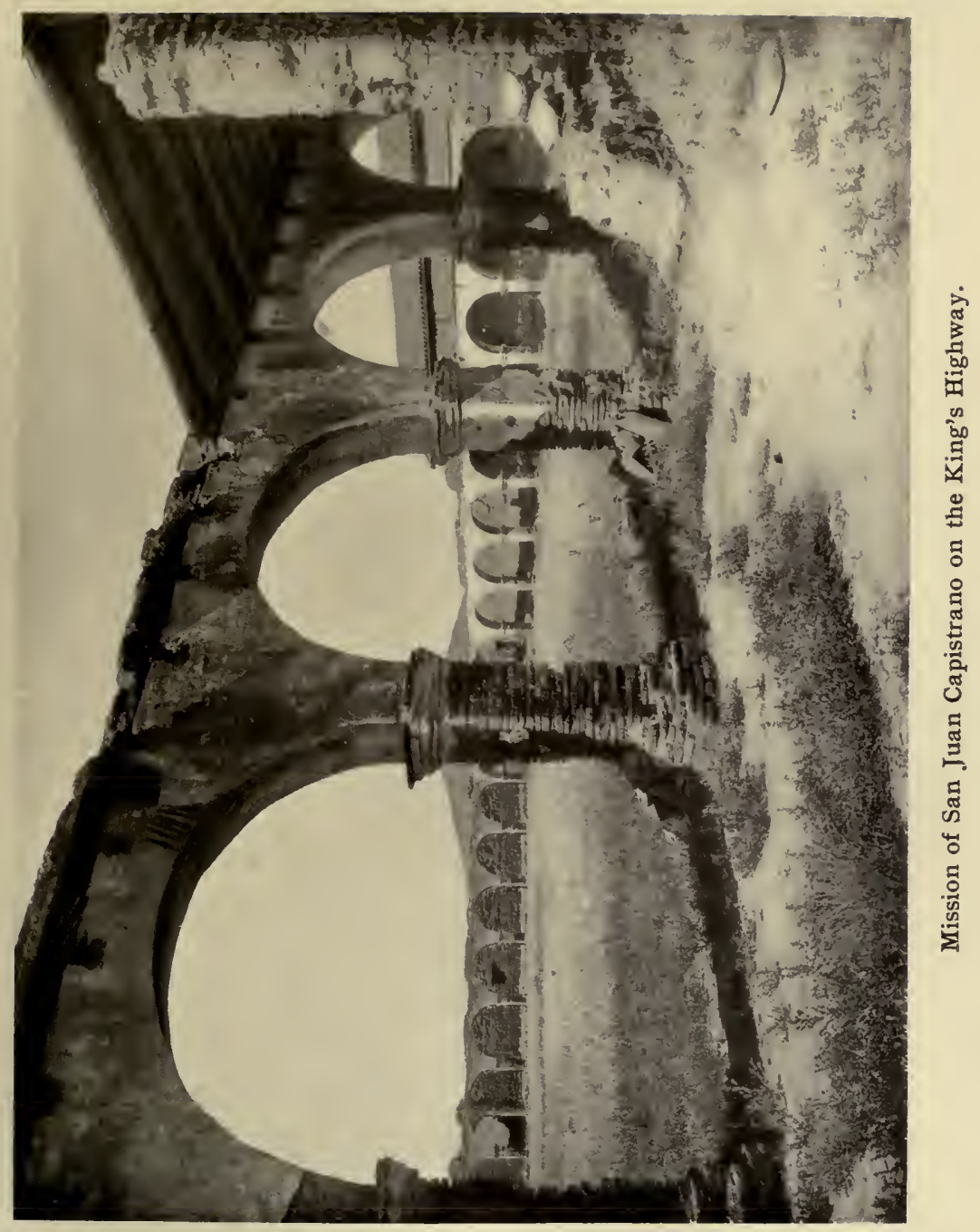



in. I can almost hear the hiss of their wings; then they turn and I watch their graceful movement and am wondering what deflected them, when around they whirl; they see the decoys, turn, and literally drop out of the sky in that splendid curve that I break, and take what fortune and the morning wind has brought; one to the right, dropping it directly into the decoys, while the flock, pounding the air, turns violently. I fire my left directly over my head and see the duck coming down on me.

Probably every old duck hunter has had this experience, but it has occurred to me but once. I dodged, and the heavy "sprig" came tumbling down, like a meteorite dropping out of the sky, struck the edge of the barrel, and rolled in at my feet. The flock has swung around, passing over another blind on its way to the sea again, and so is depleted as the white puffs of smoke rise over the green.

The sprig is the early bird in Southern California, the first to come; a fine big fellow, robed in black, brown, and white, with scintillations of violet, gold, and green. In the old days, or twenty years ago, before California was invested, I have seen the waters of the lagoons covered with them, while the adjacent lands and mounds would be white with cranes and geese. In those days the lagoons were no man's land; duck clubs were unknown, and there was good shooting in a little lake south of Raymond Hill, Pasadena, in the foothills after a rain, not to speak of the reservoirs. Then 
the irrigation ditches were alive with game, and it was a question on some ranches in the San Joaquin how to drive the geese off, so regardless were they of the rights of man.

This has all changed: almost every foot of good duck shooting in Los Angeles County, and from Santa Monica to Laguna, is taken by private clubs; were this not so, every duck and goose on the coast would be killed off by the pot-hunter, the running mate of the man who dynamites trout streams. As it is, the birds are protected, and it is not difficult for gentlemen to obtain access to the shooting privileges of some of the clubs along shore. Sport is not alone the object; the birds are conserved, protected, and fed, and intelligent laws devised for the conduct of the sport.

While we are digressing, white spots are coming up the channel of the slough, and you see the king of all ducks-the canvas-back. The first one I ever shot from a blind in the Chesapeake Bay gave me the duck fever; it was not the bird, but the fact that a flock of canvas-backs and others covering acres, so it seemed, came swimming around a turn, out into the bay, so that when I sprang to my feet that I might not commit murder on the high seas, the air was filled with climbing forms.

On they come straight for the decoys, and as the white puff drifts away, I see the canvas-back lying among them, while the rest of the flock are whirling away seaward. 


\section{Water Fowl}

The sportsman will find nearly all the ducks of the East along shore in Southern California: the mallard, gadwall, baldpate, green-winged teal, blue-winged teal, cinnamon teal, spoonbill, sprig, wood duck, red-head, canvas-back, wing widgeon, buffle-head, American scooter, white-winged scooter, surf-scooter, and ruddy duck, some of which, as we might say of crow, are more pleasing to the eye than the stomach. Of geese there are the lesser snow goose, greater snow goose, American white-fronted goose, Canada goose, Hutchin's goose, black brant, and trumpeter swan.

There is a constant coming in, on this splendid shooting ground. Here is the cinnamon teal with beautiful colouring; its gray wings striking the air like whips, its bars of celestial blue, its velvet beak blazing like a jewel,--the humming-bird of the duck tribe. It is one of the commonest of Southern California ducks, found along shore all summer, spring, and fall, going farther south in midwinter. In May, its nest and eggs may be found in many of the protected lagoons. How far this fine bird goes to the south is not known, but it is seen in Central America in February, and is one of the most attractive of its kind. To see it paddling in some snug harbour, shut in by tules, its tints blazing in the sunlight, is a picture too beautiful to always interrupt when there is other game to be had.

The mallard is a favourite duck of the people, and one of the cleverest. It comes up the little channel, approaches the decoy, then has a presentiment (surely it 


\section{Life in the Open}

sees nothing), and then literally shoots up through the air in a climb into the empyrean. I shall never forget my first experience with this manœuvre. I sat and looked in sheer wonderment, and when my old darkey companion, who lived in Hampton, on the creek, asked me why I didn't fire, - why, I gave it up. In the old days these birds could be seen in large numbers in all the lagoons along shore, becoming rarer and wilder as the country became settled, and towns and fantastic cities rose in a night in the lagunas and swamps that once knew them well.

The commonest bag along shore is the greenwinged teal. No one can watch its flight, its dash and swiftness, without becoming enamoured with it as a game bird. I have seen a flock whizzing along, have fired and missed, recovering from my surprise only to be thrown into deeper chagrin and confusion as the same flock that had dodged my ammunition came whirling back at me, so near that I threw up my hands, figuratively, and let them go. I was not out for murder or sudden death without an excuse or justification.

The mornings out on the edge of the lagoon are often cool, but soon the fog creeps away, the sun comes out, and all the life of the tule appears. Coots make the acquaintance of your distant decoys. Wilson's snipe come whirring in and alight near you in the mud, and the solitary sandpiper flies down from the pasture lands where it has been feeding to leave its footprints in the soft mud. 


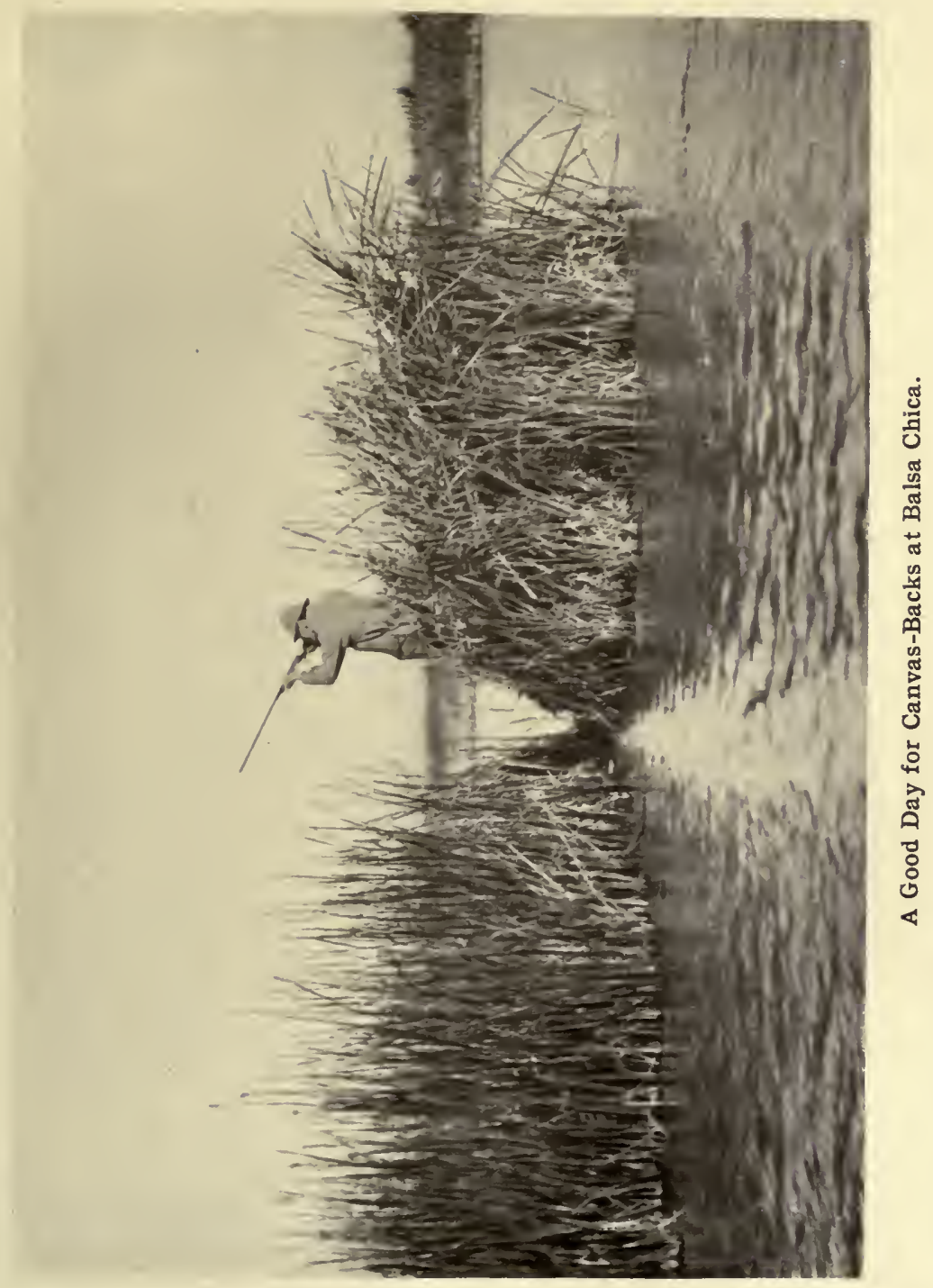





\section{Water Fowl}

If you are in good luck, while waiting you may see the least sandpiper, the avocet, and that living colourscheme the gallinule creeping in and out among the tall reeds. In Florida I have often kept this bird as a pet, it being very amenable to domestication. Few birds have a more beautiful or more expressive eye than this gentle creature.

If the sportsman finds some section of the country not a preserve and unfrequented, he will see many old friends of the East. A few years ago I could count scores of herons in the country back of Playa del Rey, splashes of white against the green; and once I hunted a flock of the snowy herons for hours in this lagoon. I crept over the dunes, edging my way along, and watched them feeding around a little island in the swamp, with sentinels posted. But the finest bird is the sand-hill crane that may be seen in the Centinela hills, and I have seen it in the Puente hills south of Pasadena. This is the bird that makes the best displays spring and fall along the Sierra Madre. Wandering along the low region that receives the seepage of the hills you may see the spotted sandpiper, the black-bellied plover, and in the wet meadows, where the lush alfalfa stands, hear the flute-like cry of the killdeer with its ventriloquistic quality coming down the wind. The mountain and snowy plover are not strangers; and on the highlands or mesas, a few miles from the sea, the long-billed curlew is not uncommon. I located a large flock of these birds on the mesa a mile back from the 
sea and north of Santa Monica some years ago, and watched them for weeks. By keeping behind my horse and working him on the flock in a circle, I approached so near that I could see their every move. They were feeding on grasshoppers.

While the geese are not so common as in the old times, the grain fields of Centinela and others in exposed positions are still raided at night by the lesser snow goose. You may walk along the shore in the afternoon and see the white platoons far out on the water, surrounded by ducks; and if you have patience, and the moon is bright, may see them coming in to devastate your alfalfa patch, or to spend the night in a revelry in your barley fields. Then there is the whitefronted goose. I found a little laguna made by the rains near the Mission hills some years ago, frequented by the Canada goose. The country near by was open and planted to barley, and when the birds had surfeited themselves, they would rise and come wheeling along, dropping down near the blind where I lay concealed. I found at first they paid little attention to my horse, which I left under a tree, and I tried to work up to them mounted, but they saw the trick at once.

I reached the lake one winter morning when the fog was thick and heavy. The hills were green as emeralds, and the drenching rains had brought out the alfileria and burr clover with a host of flowers that grew down to the very edge of the little laguna. I rode up to a low hill and looked over from the saddle; the soft verdure 


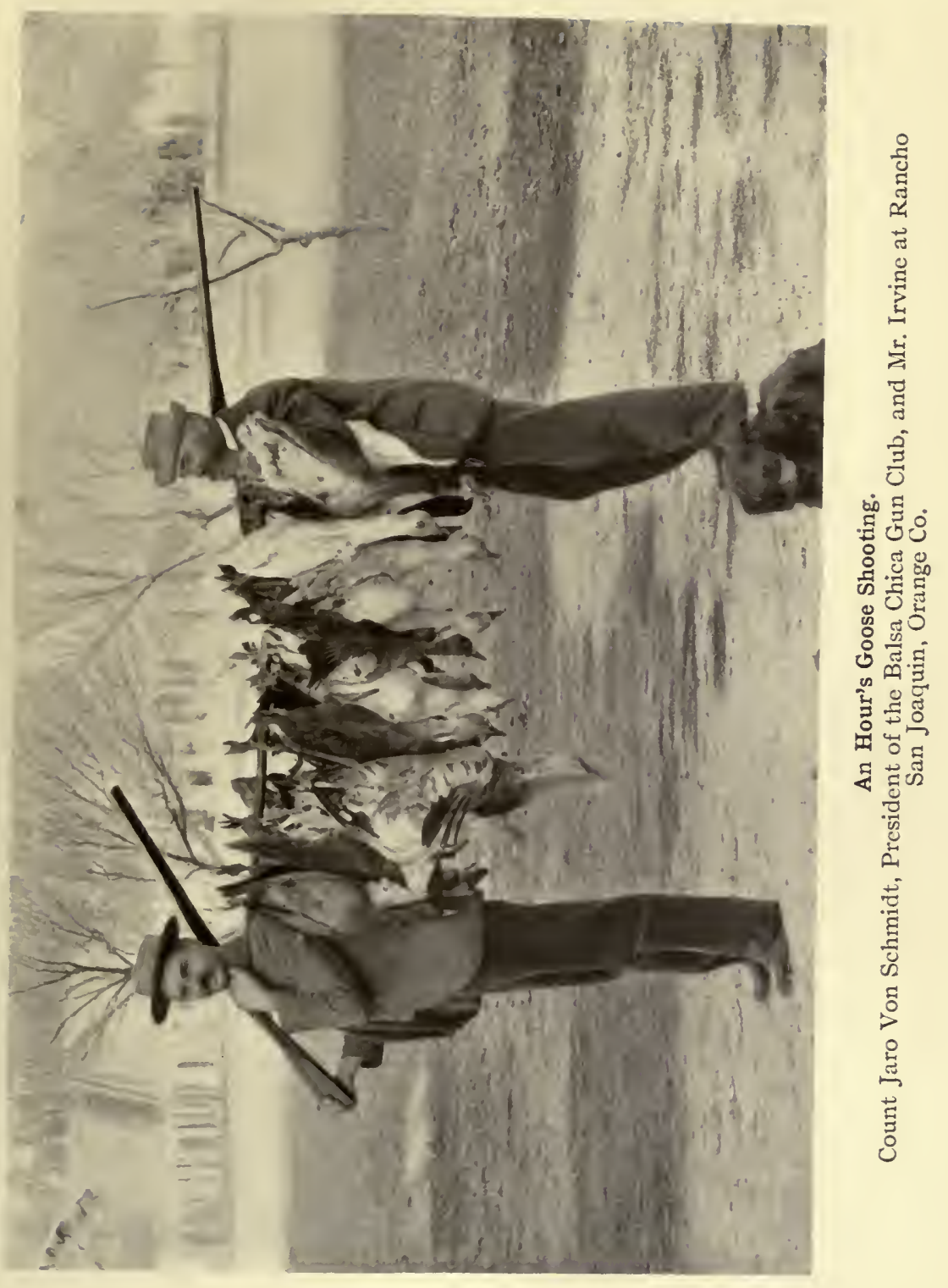





\section{Water Fowl}

that was ordinarily a floral coat of many colours was white with these fine birds. I crept around to a little cañon or wash, and, giving my clever horse the word, he charged them at a pace that brought me into the very heart of the flock. If the little lake had been blown up the effect could not have been more electrical, as the geese seemed to rise directly into the air with splendid reaches, while others, as though demoralised, swept around me like an aureola as I sat in the saddle fingering the trigger and resisting the temptation that every pot-hunter embraces. Then I took my horse some distance off and hid in a brush heap from which I watched others come in graceful alignment-a splendid spectacle. Suddenly seeing the little silver-faced lagoon, perhaps a thousand feet below them, nestled in the green, they went to pieces literally, and tumbling down out of the heavens, to alight with grace and dignity indescribable.

Here, too, is Hutchin's goose, a clever bird. All these birds present an interesting spectacle in their great migrations along the Sierras, where they are often picked off with the rifle, which, to my mind, not being in the goose business, is one of the really sportsmanlike and legitimate methods for its taking off. Game itself is but one feature of this sport; the perfect days, the grand vistas of mountains and mesa, the hills, the sand dunes, and the roar of the distant sea as it piles on the sand beyond the lagoon, all tend to add to the charm of life along the winding lagoons of Southern California. 



\section{Fox Hunting in Soulifornia}

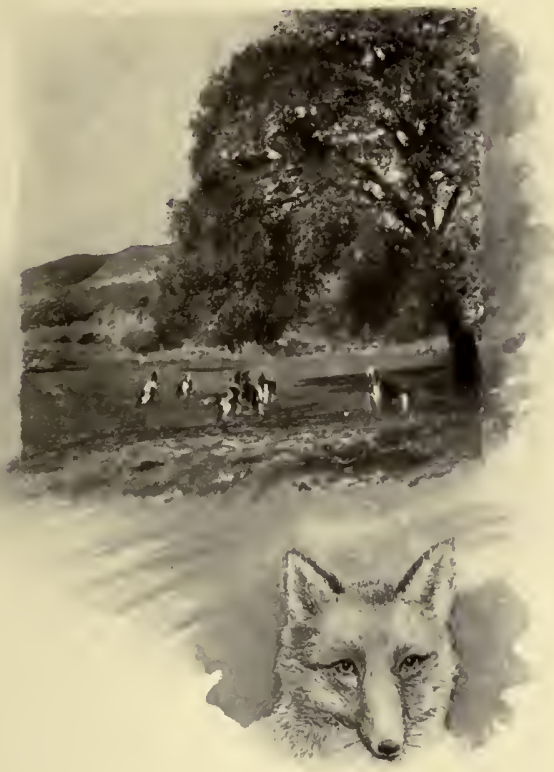





\section{Chapter V}

\section{Fox-Hunting in California}

$\mathrm{W}^{\mathrm{H}}$

HEN the scarlet berries of the Heteromeles begin to fill and glisten in the sun, when the long-pointed aromatic leaves of the eucalyptus hang listless in the drowsy air, you may know that summer in Southern California is on the wane. Up to August, in the valleys the days have been clear and warm ; in the afternoon a constant breeze blowing from the sea; the nights refreshing and cool. There has been no summer humidity, no enervating days that hold on the Eastern coast. Nearly all June and July a night fog has bathed the verdure and left glistening drops in the morning sun, and imparted to the air a resonance and tang that is delightful.

The greens of winter have melted into brown; the lower hills are rich in tones of. russet and umber, or where the barley has grown a golden gray. The foxtail grass that has rippled in the sun in rivers of green has turned to red or blue in its evolution to gleaming gold. Down the valleys great patches of vivid green 
are seen, the vineyards staggering under their burdens of grape, the orange groves, filled with half-grown fruit, have taken on a deeper tint, and the blaze of poppies of the highlands has been swept away. The chorizanthe, with its tender lavender hues, and numbers of summer flowers appear in wash and meadow. The sides of the little cañons pale in the blooming of wild buckwheat, and the bloom of the white sage welcomes the bees and countless insects along the range. On the sides of the arroyos the deep orange trumpet of the mimulus makes a flash of colour, and here and there a green sumach is overgrown by the deep red panicles of the wild honeysuckle.

In the cañons clumps of wild roses have taken on a new and tender green, and the single petalled flowers that in spring filled the air with sweetness have gone. Climbing up to and over the cottonwoods, willows, and sycamores the wild grape has formed a dense maze that reaches from tree to tree, the highway of the wood-rat, whose ponderous nest of leaves and brush encompasses the trunks of live oaks on the ground.

The summer wind has died down, the days are warm, the nights cool. Smoke rises high in air, vagrant dust spouts hang undecided in the valleys, and menacing, white domelike clouds rise thousands of feet above the wall of the Sierras, telling of the desert. The face of the land changes as the days drag along; the hills become grayer, the fiery yellow of the dodder melts into brown, and the spiked seed-pods of chilocothe hang on 


\section{Fox-Hunting in California}

the cactus, half covering the brilliant, pinkish yellow flowers, and in the washes down by Sunny Slope, and in the open, yellow gourds lie ripening in the sun.

It is late in September; a yellow diaphanous haze fills the drowsy air, and the colours of cañon and mountain are intensified. The front range is a light, hazy blue. Over the divide the second range takes on a deeper tone, while the tip of some back and distant peak is purple; the entire range a maze of delicate tints, as though a great tourmalin lay glistening in the sun.

The cork oaks and pines pipe fairy music in the drowsy air and the cañon streams run low, here and there dry or just moist enough to show the track of some dainty footprint,-quail, wood-rat, or snail.

It is at this time, the period of dolce far niente in Southern California, that the thoughts of hunters turn to game. There has been no rain since May, perchance, but suddenly at night comes a gentle fall. The great, white cloud mountains from the desert have been blown over into the valleys of delight, and the first rain has fallen. It is out of season, not normal, and has no significance. Hardly a seed responds, and it is just sufficient to lay the dust, to soften the sand in the arroyos and cañons, just enough to hold the scent of the little gray and red fox as he steals along the washes in search of quail or rabbit.

This explains your presence in the arroyo early in the morning, while the sun is climbing over the 


\section{Life in the Open}

distant mountains, sending shafts of fiery red into the deep blue and purple cañons. The washes of the cañon are almost dry; only stepping-stones of rock tell the story of a winter stream; but that the water is flowing along beneath the surface, the cottonwoods, willows, great brakes, and tall grasses suggest.

The hounds, followed by the hunt, have wound down a little trail into the gulch, where they spread out and cover the stream and its branches. O-0-0-0! rises the deep silvery sound floating through the trees; $0-0-0-0$ ! then faster, and the hounds stop a moment before several plastic impressions in the sands, and break into a volley of resonant bays Oou, Oou, O-0.0-that are carried far into the brush; now along the sandy reaches, up over mimic sand dunes, down into small pools where windrows of shining mica lie like gold, up the bare side of the cañon, into great masses of brakes and ferns, startling a bevy of quail, old and young, that rush away with loud whir, whir, whir of wings. Louder the deep tones rise, culminating in the ecstasy of melodious sounds, and the horses are rushed through the underbrush to find the pack leaping about an old oak up whose sides trail a mass of green-the wild grape of the arroyo. The dogs are looking upward; some at the foot of the tree, vainly trying to leap into it, others farther off eying the branches with eagerness, occasionally letting out a long, plaintive note that is borne far away through the drowsy air.

I had followed the fox in Southern California before, 


\section{Fox-Hunting in California}

so kept my eye on the wild grape where it fell over and covered the limb of a sycamore. As I looked, out from among the long broad leaves I saw a small, black-gray face, a pointed muzzle, and big ears. It was Reynard, and in defiance of any Eastern or English code of fox ethics, he was in the tree-top very much at home, embowered with the grape, and under a canopy of light-green mistletoe. The dogs had not discovered him; they were still playing on the accuracy of their scent. Then some one lifted an old hound into the tree and the dog began to pick his way upward. Any one who has never seen a tree-climbing hound will hardly believe how high a clever and eager dog will go in a slanting oak or sycamore. This hound felt his way up and literally bayed the fox from its arboreal cover. Out it sprang, in full sight of the hounds that went baying mad; it ran along the grape highway, as nimbly as a wood-rat, leaped into the sycamore, out upon a long branch to plunge down the vines, and as quick as a beam of light, dropped into the chaparral and disappeared with the hounds in full cry.

It was my good luck to fall into line directly behind the hounds and I saw the fox take an oak. It did not spring, but deliberately shinned up the small trunk, reaching a limb upon which it swung, then leaped into the thick branches and ran from tree to tree with a speed with which I could not keep up, owing to the thickness of the trees, reached the opposite side of the arroyo, and from a small sycamore sprang into the 
underbrush. Directed by me the hounds soon took the trail and followed the fox for half a mile along the edge of the bluff; now under scrub oaks, out by great clumps of Heteromeles, whose berries were swelling in the sun, then passing down a little side cañon it made for the main branch, and went up and over the ridge, to be followed by the baying of the hounds.

The hunt was forced to go around, and after a long ride through the chaparral came upon the pack. They had run the fox up into the thick branches of a "holly," where, not five feet out of reach, this diminutive Reynard sat snarling and growling at them, to make a brave jump and carry the hunt a hundred yards, where on the edge of the cliff it was caught, carrying one of the dogs over into the green abyss, rolling down, followed by the baying, yelping pack and the hunters, who, dismounting, slid down into the green to secure the brush, which was presented to the lady of the hunt whose plucky riding had commended itself.

The game was hardly half as large as the ordinary fox of the East, and known as the coast fox; found all along the Californian shores and on all the islands; ranging from Costa Rica to the north-west, varying in appearance in seasons and in localities. The tail is about the length of the body in the average animal. I have seen a specimen in the mountains of Santa Catalina where it was a splendid ornament. The tail has a black stripe above, and the fur of the body is dark, even almost black above and reddish below, with variations 


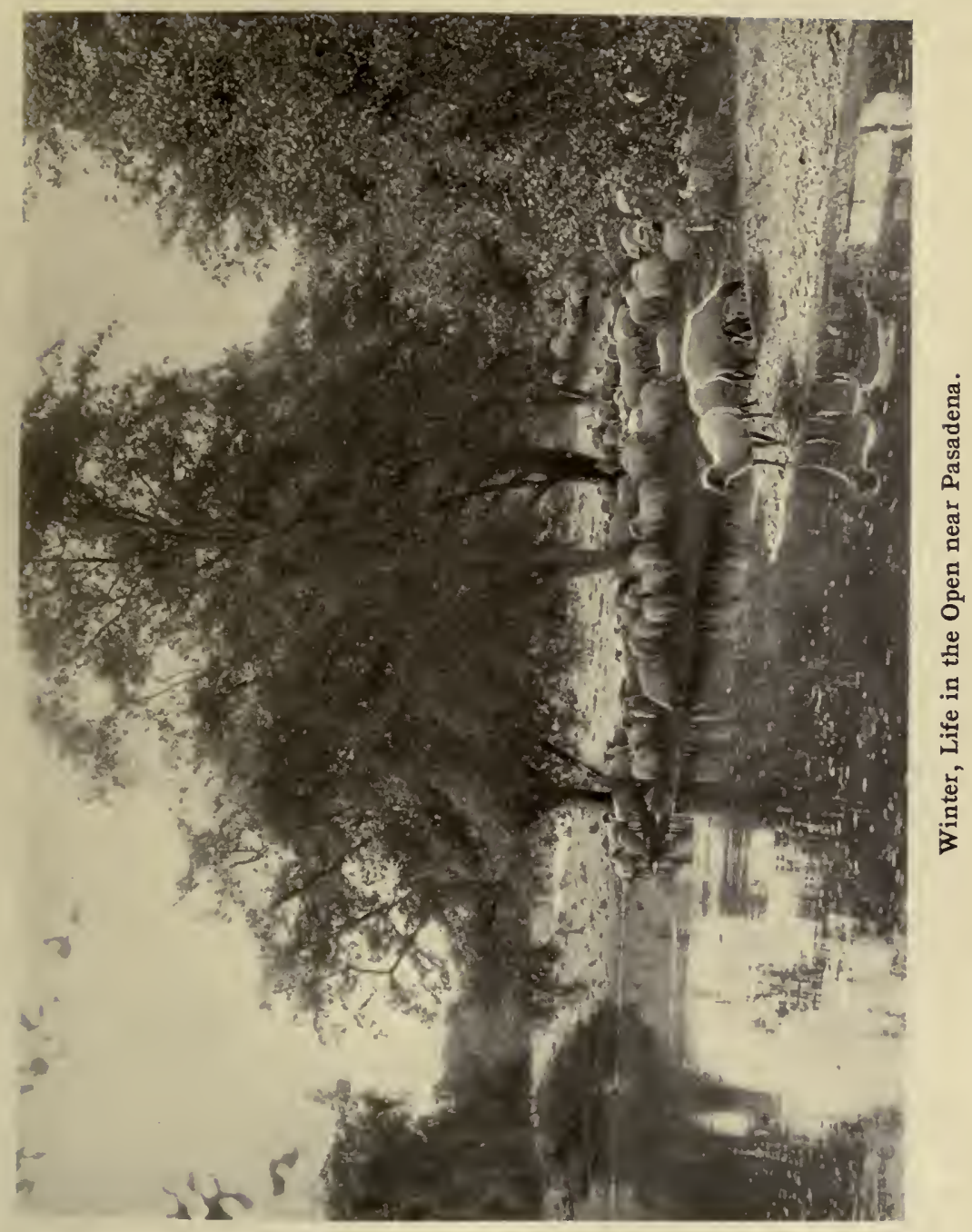





\section{Fox-Hunting in California}

in colour. The sides of the muzzle and the chin are black, which gives the fox the appearance of a raccoon and withal a very pleasant face. It has a large head, quite as large in some instances as that of the gray fox, but in habit the California fox is entirely different. The gray and the red fox are runners, while Reynard of California rarely makes a very long run, and always takes to trees when hard pressed, leaping into them when it can, "shinning" up when it cannot. I have watched these foxes at night by the light of the moon, when they thought they were chased by a coyote. They went up the straight trunk of an orange tree by this process, "hitching along," embracing the tree like a cat, and once on a limb reaching the others and the top of the tree in a marvellously short space of time.

I once kept two foxes as pets. A paisano brought them to me and said that they were tame, but I learned later that one bit him eight or ten times on the way down from the mountain. I fastened them to a tree as I would dogs, and invariably found them in the tree-top in the morning. In the arroyo the fox lives in the thick masses of vine during the day, makes his den in some hole in a cliff, coming out mainly at night, though I have often met them in the daytime in the chaparral that covers the lower hills. Any cañon that comes down from the Sierras is the home of this little red and gray fox. You may find him at Santa Barbara, in the beautiful glens and defiles of the Santa Ynez, or along and around Bear Mountain, back of Santa Paula. He 
looks down upon the mountains from the Strawberry Valley, around Idlewild, and the great slopes of San Antonio and the clefts of Mount Wilson are his home; or you may find him in the Santiago mountains, where he forms the game par excellence for the Santiago Hunt Club, and doubtless helps himself to the chickens of the master of the hounds when the pack is away on a hunt; indeed you may find this little fox on San Nicolas Island, and on San Clemente, where he is smaller than ever. Everywhere he preys upon quail, or small birds, varying this diet with tuna, wild grape, or chilocothe.

They are particularly common at Santa Catalina. On the summit of this island is a range of mountains, named for Cabrillo, the discoverer of the island, which have several isolated peaks, twenty-two hundred feet in height, surrounded by a maze of cañons. In between these, running directly across the island, is a long and well-wooded cañon, in its lower range called Middle Ranch, the Cabrillo range forming the south wall of green. In camp here one is never away from the melodious note of the quail, while the foxes make a runway down every cañon and along the tops of the range where great reaches of low chaparral sweep away to the sea. At San Clemente they stole from my camp and came around every night.

Fox-hunting is indulged in all over California, but it is a failure in the open. The fox will make a long run in the chaparral, but in the open country he will run for the trees in sight and leap up their sides with 


\section{Fox-Hunting in California}

great abandon. I remember well a "fox hunt" on the mesa in my early days in California. A fox having been located in a little woodland on a wide mesa that afforded a splendid running country, a hunt was organised and in due time the fox started. I was the Master of Fox-Hounds that day, as well as the President of the Club, and the hunt was looking to me to carry out the plan of an old-fashioned Virginia fox hunt. The hounds took the trail, and the fox responded. $\mathrm{He}$ dashed across the mesa, stood a second surveying the landscape, then selecting the only tree in sight-an oak-he ran for it, and the hunt and pack in full cry followedfor perhaps three hundred yards; then Reynard reached the tree, gaily bounded into it, and was placidly sitting out of the dogs' reach washing his face when the hunt rounded up. It is best to draw a veil around so harrowing a scene, but I believe I carried that fox home, brush and all, under my arm. In the cañons the fox is another creature, or in park-like regions, as the splendid reach at Santa Anita rancho, or Santiago or Monticeto cañons. Here the hounds often have a long run and are often baffled.

The Santiago Hunt Club averages about fifteen foxes a season, often taking them in September and October, the driest time of the year. The dogs of this club are doubtless the best foxhounds now in Southern California. Mr. J. E. Pleasants, the Master of Hounds, and Mr. C. E. Parker of Santa Ana have taken great interest in perfecting Californian foxhounds from stock from the 


\section{Life in the Open}

Southern States. An average run of this club after a fox, is given as three hours, the fox being generally treed four times in this time, and often killed in the open after a run of perhaps three hundred yards.

While fox-hunting may be had in summer and as the latter wanes in October, it is better in the winter when the land is green and the herbage in secluded places damp, holding the scent. Then the country is ablaze with colour. The mesa, cañon, arroyo, and mountain slope each has its special floral offering to delight the hunter, and life in the open can be had in all the term implies. Immediately after the first rain is doubtless the most favourable season. The land is still warm and dry. Perhaps in mid October, there is no suspicion of a change, and a thick golden haze hangs in the valleys, so that one seems to see the mountains through opalescent lace. The nights are a little cooler, the wind has about died away, and for days flocks of geese and cranes have been seen flying south along the Sierra Madre.

You are familiar with the fog that comes in from the sea against the wind at night in an altogether incomprehensible fashion, going out against the sea breeze in the morning, the tonic of Southern California, the balance wheel, the only fog in the world possibly that is purely harmless, crepuscular, nocturnal, and other things. But one day this fog, in a long, feathery, fan-shaped finger, is seen creeping along the slope of the Sierras in the morning. From my home in the San Gabriel at Pasadena, it appears to come up the Santa Ana River 


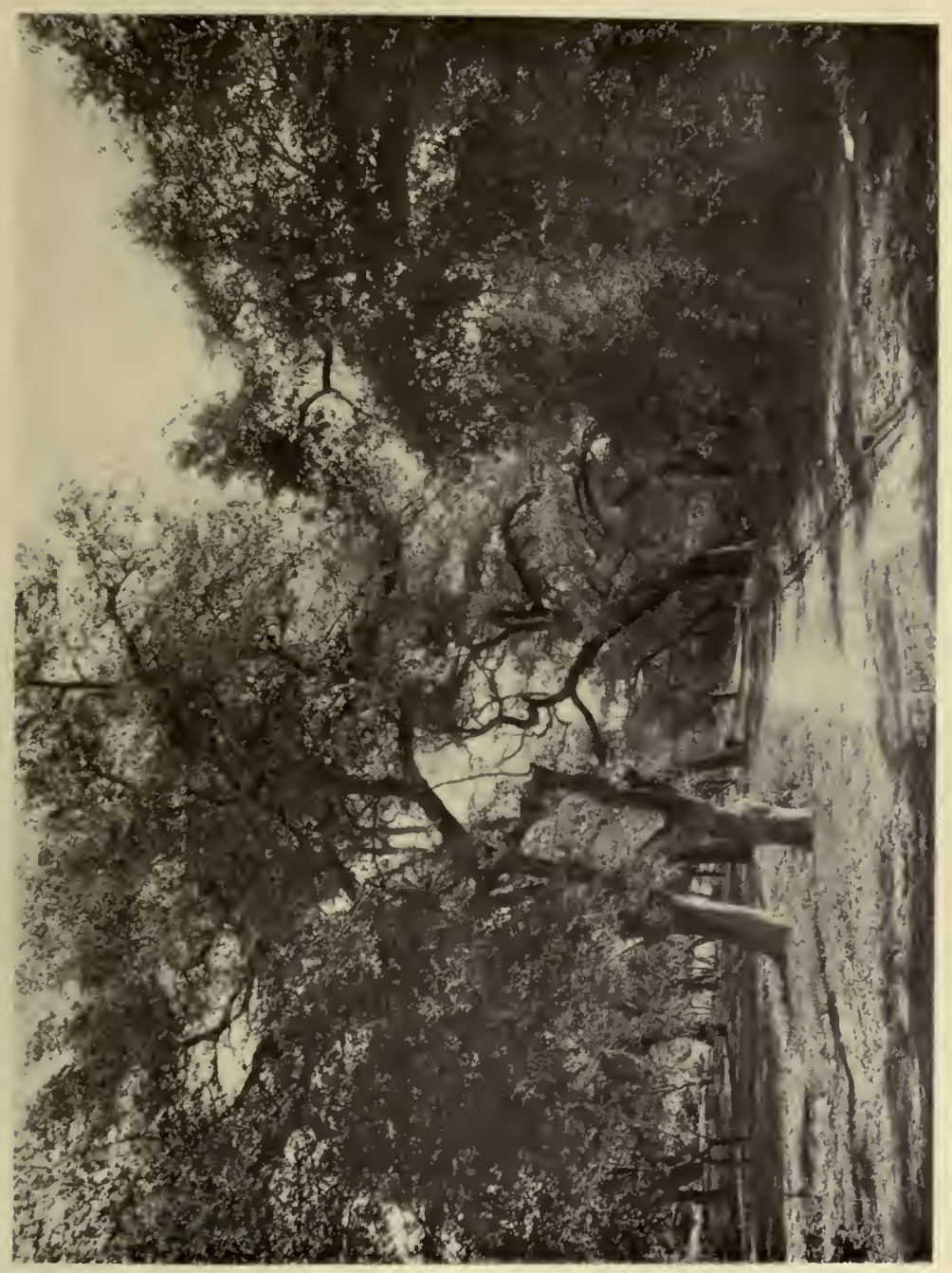

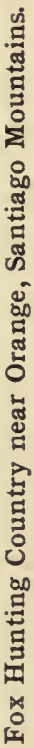





\section{Fox-Hunting in California}

from the sea, while another comes stealing along the Sierra Santa Monica range, and they meet at the main range.

If this is a real rain, not a false alarm, it spreads out and encompasses the whole land from the mountains to the sea, and after much coming and going, halting and coming again, the rain falls softly at night. I have known enthusiasts to go out and stand in it, when it has not rained for eight months. It rains gently all night, and in the morning the clouds slink away and leave another land. The golden haze that has filled the valley is gone, there is a new tone, a new world; the dust has been washed out of the atmosphere, the trees are green and bright, the Heteromeles hold up their ripening berries, and wild lilac, ironwood, manzanita, and a score of trees and bushes take on rich green tints under this night's washing. The orange and eucalyptus groves are freshened up and all the earth, covered with its brown and seared mass of winter vegetation and seeds, takes on a darker brown. Then is the time to take out the hounds; the damp sand of the cañons is covered with grey leaf mould that photographs the imprint of fox or bird, and retains the slightest odour, and the hounds at once pick up the scent and follow it over and through the devious paths and trails of the deep cañons.

The fox is a very minor part of fox-hunting in Southern California. I have spent many God-given days in the cañons of the range, from Santa Barbara 
to San Luis Rey, where the fox was but an excuse, a leader to bring one in touch with new beauties, new scenes. I spent an entire winter in the Sierra Madre between two of its most attractive cañons, and very frequently went hunting with a grey- or foxhound. What game we found and ran to earth in these splendid glades! We found banks of wild tiger lilies, cliffs with backgrounds of bluebells; there were brakes as tall as a man, fragrant bays, and down the valley, on the slopes by San Jacinto, the Matilija poppy with great white petals and golden centre. We hunted the fox in the splendid Santa Margarita Rancho that overlooks Elsinore, and wandered among the mountains that rise back of the fine old Missions of San Juan Capistrano and San Luis Rey. We hunted in the Coast Range, down the cañon of Laguna with its many caves, and along shore, where the rocks reach out into the sea. All over Southern California the little fox is found, and I commend it to the sole and tender mercies of your camera at times when the hen-roosts are not robbed. If it is a good fox-hunting winter, this first rain holds for several days and gives the thirsty earth an inch or two of rain; then watch the staging of nature's transformation scene. The change is so sudden, comes on so quickly that almost the following week you may see the alfileria rippling away over lowland and mesa; the rains have washed the seeds of the clovers in windrows, and the first green along the roads and trails comes in circles, and arcs, then fills the interstices, and 


\section{Fox-Hunting in California}

a robe of verdure reaches away over the hills that daily take on richer and darker tones. From now on there is a procession of plant-life from the far north to $\mathrm{Pa}$ lomar, and from Pala to the sea. 



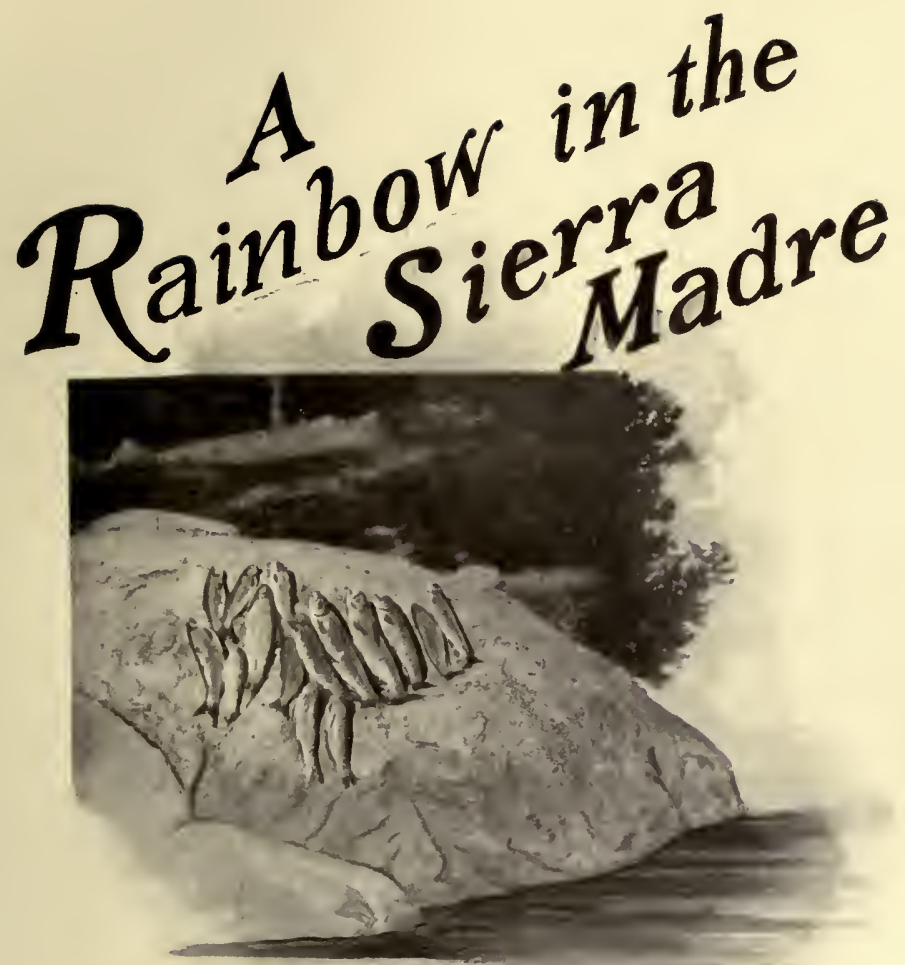





\section{Chapter VI}

\section{A Rainbow in the Sierra Madre}

I February or March the disciple of Walton, in Southern California, begins to look over his flies 1 and appropriate the big worms which come to the surface at this time in the gardens and ranches, as though to challenge fate.

The land is still in the grasp of winter; the high peaks of the Sierra Madre, San Jacinto, and San Bernardino are white with snow; and over the orange trees in my garden, where the birds fill the air with melody, I see a white, fluffy, zephyr-like cloud hovering like a bird on San Antonio; yet not a cloud, but snow rolling up the north slope, to be whirled and tossed into the air, a titanic wraith, that falls and is dissipated by the soft airs that float upward from the valleys that reach away to the distant sea.

There has been a snow-storm in the San Gabriel. The walks in the garden are white, and the strong west wind plays over it, robbing the violets of perfume. But the snowflakes are the petals of orange blossoms, that 


\section{Life in the Open}

fill the air with fragrance, and star the green trees of the groves with silver frosting.

The country in the open is running riot with flowers. It has been a rainy winter and the fall came early. Twenty inches have fallen, and, as though touched with a magic wand, the gray sombre beauties of the land have melted imperceptibly into green. You may almost see it spread and kindle into flame, so subtle, so rapid, is the response of nature to the call of winter or spring. Over all the land is spread a carpet of alfileria, soft as velvet, and radiant in changes of shade and tint, as the days slip away. On this carpet flowers are budding and blooming, and as the trout are pushing up-stream against the floods that are coming down, the land becomes a garden of many colours. The upland slopes, the great mesa in the San Gabriel and beyond, are a blaze of golden yellow. The copa de oro has opened, and the land is a field of the cloth of gold, the cups of gold covering barren slopes, drawing a mantle over ragged wastes and washes, as though all the mines of Southern California were flowing liquid gold that ran over the length and breadth of the land.

There is a procession of flowers as the weeks pass: bells of cream among the barley or by the roadside, bells of blue along the trails, violets of gold and brown in the fields or on the hillsides, radiant crucifers in yellow and white, shooting-stars, mariposa lilies, and a host of others. While it is still winter in the East, Southern California is a wild-flower garden. 


\section{A Rainbow in the Sierra Madre}

As the days pass, the floral display seems to attain its maximum effort, and then there comes a change; Spring is pouring her glories into the lap of Winter. The rippling fields of oats and barley take on a lighter green; the south face of the range, especially the spurs of the lower mountains, begins to turn and assume umber and grey tints; new and strange flowers appear; the alfileria seeds are boring into the soil ; the wild-oat awns are twisting and untwisting, day and night, and the clovers lie brown on the surface. Tall green forms are now seen on the hills,-forests of green against the slopes ; suddenly they turn to a golden hue, and over the hills the golden glow of the mustard races, bends with the wind in varying shades, until in places the entire range of hills have become mountains of gold through which one can ride, the blossoms meeting over the horse's head.

On the mountain slopes the green Heteromeles are spangled with white blossoms, and the sage-covered mesa waves in masses of gray and green spires. Along the foothills a little wash is covered with wild roses that are now in bloom, filling the air with fragrance. The Arroyo Seco, the San Gabriel, the Santa Ana, and the Los Angeles rivers have in the centre of the gravelly waste a silvery stream of water ; and so by many tokens the angler in Southern California knows that winter has waned, and April, the month of anglers, when the rod may be plied, has come. If the winter has been very rainy, if thirty or forty inches has fallen, about the annual fall 
of New York, the cañon streams will be running full, and the angler will have to wait for the falling of the waters, but if the fall has been normal (eighteen or twenty inches), good sport may be had in all the streams from San Luis Obispo to San Diego.

Southern California in summer has to some a forbidding appearance. The flowers have gone, the sunlit hills are dry, and the greens have become browns and grays of many tints, yet all attractive and appealing to the lover of colour. The great vineyards are green, the groves of lowland oaks, as at Arcadia, Pasadena, and La Manda, in the San Gabriel Valley, the Ojai, and similiar localities, are ever green, but the open, tilted mesas, except where covered with chaparral, are brown and gray; and the streams, patches of white sand and polished gravel, lie blazing in the sun, certainly not suggestive of trout, rod, or reel. But these California rivers are flowing, seeping on beneath the ground, and by tracing them to the founts from which they come-the cañons of the Sierra Madre, the Santa Ynez, and other ranges-the angler finds himself in another world, the home of the rainbow trout.

The Sierra Madre face the sea in Southern California. At Santa Barbara a range-the Santa Ynezalmost reaches it. The Sierra Santa Monica range leaps into the ocean, and to pass the beach the angler enters through a natural arch of conglomerate. From here the main range retreats, forms the background of the San Fernando and San Gabriel valleys, the valley 


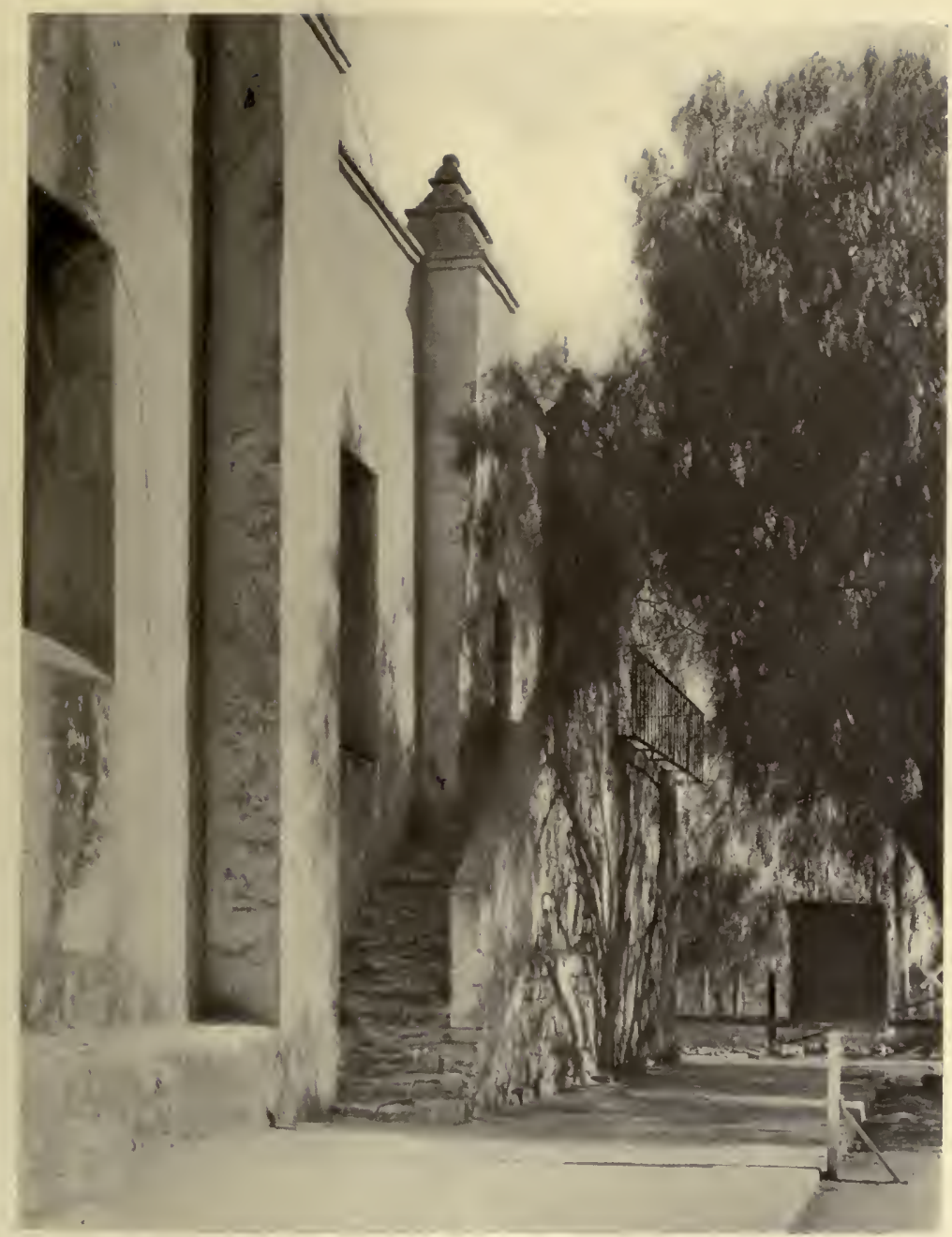

The Stairs of the Mission of San Gabriel Arcangel near Pasadena on the King's Highway. 



\section{A Rainbow in the Sierra Madre}

of Redlands, and so on, while a coast range, with Mount Santiago as its Titan, skirts the coast within a few miles of it far to the south.

Indeed, Southern California is a maze of mountains and its towns and villages are all on mountain slopes, or in little valleys, shut in by vagrant ranges or mountain spurs that seem to crop up and to extend in every direction. The main range stands out clear and distinct, a wall of rock, often seemingly bare and barren, facing the sea. It is cut and worn by the wear of centuries, and while the first impression may be disappointing, the possibilities of this barrier of stone, in colour making, in grand and beautiful effects of light and shade, are soon appreciated. The mountains seem to be a mass of pyramids, and are cut by innumerable cañons that wind down from the summits, each having countless branches. At irregular intervals, the cañons open into the valleys and sweep on, like the Arroyo Seco, almost to Los Angeles, ten miles distant; cutting a deep and well-wooded gulch, which tells of the force of the winter floods that, beginning far back in the range, come rushing down augmented by thousands of smaller streams, and go whirling on to the distant sea.

These cañons are the gateways to the Sierra Madre, and once within their rocky portals, all thoughts of barren mountains are dissipated, as they are natural parks, filled with green bowers, sylvan glades, banks of fern, the music of the rushing brooks, and the gentle rustling of countless leaves; while the air is rich in the 
woodland aromas - of bay and many more. The cañons are found all along the range, and nearly all have a perpetual stream like the Arroyo Seco, the San Gabriel, Santa Ana, and Santa Ynez, the cañons and streams in San Buenaventura and Santa Barbara, and they are stocked and protected by game-laws of the State.

In the vicinity of Los Angeles the San Gabriel Cañon affords the best fishing, being a large cañon that reaches far back into the range, to appreciate which one nust stand on Wilson's Peak, six thousand feet above the sea, and look down into this great gorge worn out by the water. This cañon and its forks abound in trout pools, in picturesque rocks, precipitous walls, and splendid vistas of mountains rising one above the other, peak above peak, range above range. Here the Creel and Bait clubs make thẹir headquarters; and there are several public camps which afford accommodations for the weary angler.

The cañon trail crosses and recrosses the stream of clear water; now plunging into mimic forests of oak; coming out into the open to enter little glades; sometimes the cañon opens out widely, again it narrows and forms great rifts in the rock. In the open places there are little mesas, often dotted with oak trees-ideal places for camps.

A succession of these beautiful cañons is found along the entire face of the Sierra Madre. On the first of April every trout stream from Santa Barbara to San Jacinto and beyond has its anglers. Some idea of the 


\section{A Rainbow in the Sierra Madre}

beauties of these resorts can be had by a four-mile ride from Pasadena, at the head of the San Gabriel Valley. The town lies on the bank of the Arroyo Seco, which abounded in trout for almost its entire length some years ago, but they have been forced to the upper ranges. A fairly good trail extends up the cañon twelve or fifteen miles, taking one into the very heart of this part of the Sierra Madre. Near by is Millard Cañon, a beautiful gorge with a notable fall splashing over beds of ferns, the cañon then winding its way upward six thousand feet above the sea.

The San Gabriel Cañon, the head waters of the river of that name, always has fishing unless the water is too high; but the smaller cañons fail sometimes for opposite reasons, the supply of rain often being too low for a period of years, killing off the fish. But in fishing all is not fish, and some of the most enjoyable days I have had in Southern California have been in the heyday of the Arroyo Seco, when its pools were full, and its stream musical, laughing waters. Countless times the trail crosses the stream, and I have stopped at the crossing, and, while my horse cooled his hoofs, cast down the stream from the saddle and hooked a fish in the riffle.

A delight-giver indeed was this stream. It began far away in the upper range and drained many square miles of surface; cool, pure as crystal. I often stood on its edge, or on some rock, and watched it go whirling by; now loud and melodious, as it ran over some rocky 
reach, then gliding smoothly over a moss-covered incline to rush out into the open and form a little lake where the willow leaves made an arcade of green tracery over its surface, and their red roots blazed in the shallows. Here great banks of ferns and brakes grow beneath the bays, and just above, you cast and unreel and let the capricious stream take you down the stream. It seems an impossible place, with its polished rocks, projecting ledges, the big tangles of brush, but down goes the fly to the melody of running waters. It shoots along, enters a little arcade of brakes, and then, ah! how the line straightens out; a new and unknown music, the click of the reel, breaks in upon the rush of waters and the rustle of leaves; how the slender rod bends and doubles as the gamy trout of the Sierra Madre makes its rush down-stream, dashing by polished, slippery stones, around the smooth edge of boulders, through the rift where the sun blazes brightly, and caressing the water with its sparkle, out and along the edge, to stop, double around a stone, and come upstream with a flying rush. This is a trout stream indeed. There is not a ragged stone in sight; the waters have worn and polished every one, so that even the tree-toads that mimic them have difficult work to hold on. This saved the day, as the line slipped deftly over their sides and came taut just as the gamy fish made another splendid rush clear away, with the reel in full cry, zee, $z e e$, zeeee, echoing musically among the willows and alders. Nowhere was the water over a foot in depth. 


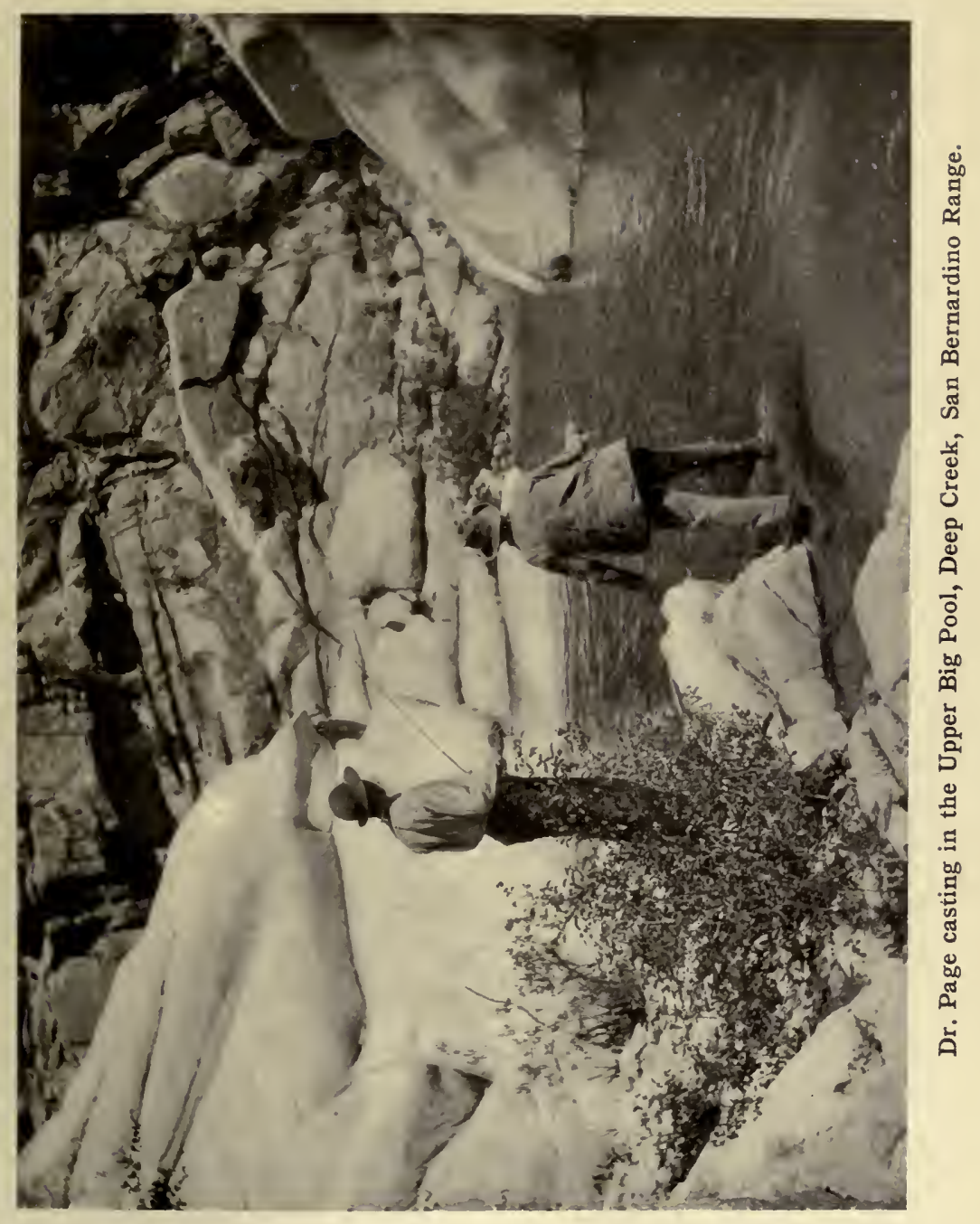





\section{A Rainbow in the Sierra Madre}

There were no deep pools, yet this radiant creature played his game with a skill that was marvellous. In he came on the reel, bending the split bamboo to the danger point, then breaking away in the riffle, bounding on slack line into the air a foot or more, shaking himself like a black bass, landing almost in the shallows to shoot into midstream in so gallant a rush that I was forced ahead, and led down through the green where he plunged into a little cascade, made a quick turn, and dashed into a wide but shallow pool, taking his place beneath a huge combing rock to defy me, forcing me down so that I had to cross the reach and play him from a little gravel beach in the eddy. As I routed him out he went into the air, and for a second I saw him in a rift of the sun-a radiant, beautiful creature, too beautiful to catch. Time and again he manœuvred to go up or down, but by more luck than skill I kept him there, played him to a finish in what was doubtless his home, and brought him, fighting, to the net, the living rainbow of the Sierra Madre.

I have landed brook and lake trout and some of the gamiest fishes of the sea, but inch for inch this trout of the Coast Range, this Salmo iridius, is the peer of them all. Perhaps it was my fancy, possibly I was carried away by the beauty of the place, the charm of the situation, but I forgot certain black bass, certain brook trout, and a wild, miniature gorge I knew in New England, and mentally awarded the rainbow the palm.

The fish which I took from the net weighed nearly 
two pounds and was an ideal trout - a splendid fellow, that, dying, eyed me with disdain. He was well proportioned, and comparing him to the brook trout I saw that he had larger eyes, a small mouth, the head more salmon like. His colour on the back was an iridescent green ; the sides lighter, tending to white, and dotted, stamped with small, black, velvet-like spots, while from gills to tail was a band of reddish blotches, a combination that blazed like a rainbow when the trout leaped in the sunlight.

I kept on up the cañon, following the trail, then taking the stream and fishing down, in short sections, with varying success and always a splendid play from the animate rainbow. In these wilds of the Sierra Madre, at least half the charm is the environment. I walked or rode, led on and on by the constant change, then turned and followed the stream in its race to the sea, to again turn back. As I worked into the range the cañon deepened and large pools and deep gorges appeared. Once I crept up to one twenty feet across; and on its rim grew masses of brakes, olive-green plumes that caught the slightest breeze. Opposite were groups of wild lilac, its delicate lavender flowers showering into the pool, while long, pointed bay-leaves, like mimic ships, and acorns nearly two inches long, that had rolled down the cañon side, floated about. On one side clumps of columbine made a blaze of colour; and on the other a vivid green carpet of moss marked the passage of the stream from the pool above; the water coming gently down like a sheet of quicksilver. 


\section{A Rainbow in the Sierra Madre}

Into this mirror of delights I cast, dropping a fly directly at the foot of a white rock, with no response. Again I tried, then, failing to secure a rise, I climbed above and crept through the verdure, pushing aside big bunches of fern, to the edge and looked in.

The water was a splendid emerald green, and at the bottom I made out several trout gently fanning the current. The next fly bore a worm, but not a fish moved. I tried all the flies I had, and finally in desperation caught a tree-toad from the rocks and cast.

This was the lure of lures. A great trout came partly out of water, like a flash of light, and then something went bounding into the air, shooting over the edge of the basin down the stream to the next pool. It is always the largest fish that escapes, and I have been told trout have been taken in this stream that weighed fourteen pounds. I think I saw one, for a fleeting moment, against the green brakes; but it is needless to harass the memory.

If one had the space and inclination to chronicle the various tales of the rainbow trout, its leaps and plays, a small volume could be made on this fascinating theme alone. A friend told me that in casting with three flies two fishes saw them coming, met them a foot or two in the air and were caught after a splendid play.

Late in the afternoon I came to a deep pool of the arroyo abounding in trout of small size, and might have filled my creel, but I climbed the cañon side, made the 
trail, and later crossed the stream and rode into camp, twelve miles from the valley, four thousand feet up, and in the heart of the Sierra Madre, with range after range between me and the sea. The camp was a log-cabin of an old mountain friend, and that night I sat by the fire and looked up the chimney and counted the stars, listened to the cry of strange birds and the weird laugh of the coyote, and breathed the rich odors of forest trees, noctes ambrosiance. Since then this attractive cañon has been swept by fire, and has lost much of its beauty; but new trees are growing, and Nature will soon renew its delights and fascinations.

The San Gabriel Cañon with its splendid reaches is the home of the rainbow trout, and some fine catches have been made here by lucky anglers. The San Gabriel River is available from several points. The angler will find the Mount Wilson Trail at Eaton Cañon, Pasadena, a delightful diversion. It carries one from Pasadena eleven miles up the slope of the Sierra Madre, nearly six thousand feet above the sea; affording innumerable views which well repay the trip, aside from the objective. The summit of Mount Wilson is an attractive park, the site of the astrophysical observatory under Dr. George E. Hale. Near here are two camps or hotels where the angler will find congenial entertainment, and the latest fish stories. The trail down the north slope is about four miles in length, and can be made by burro or horse, or on foot, and the angler will find one of the most tremendous "drops" in the Sierras, literally 


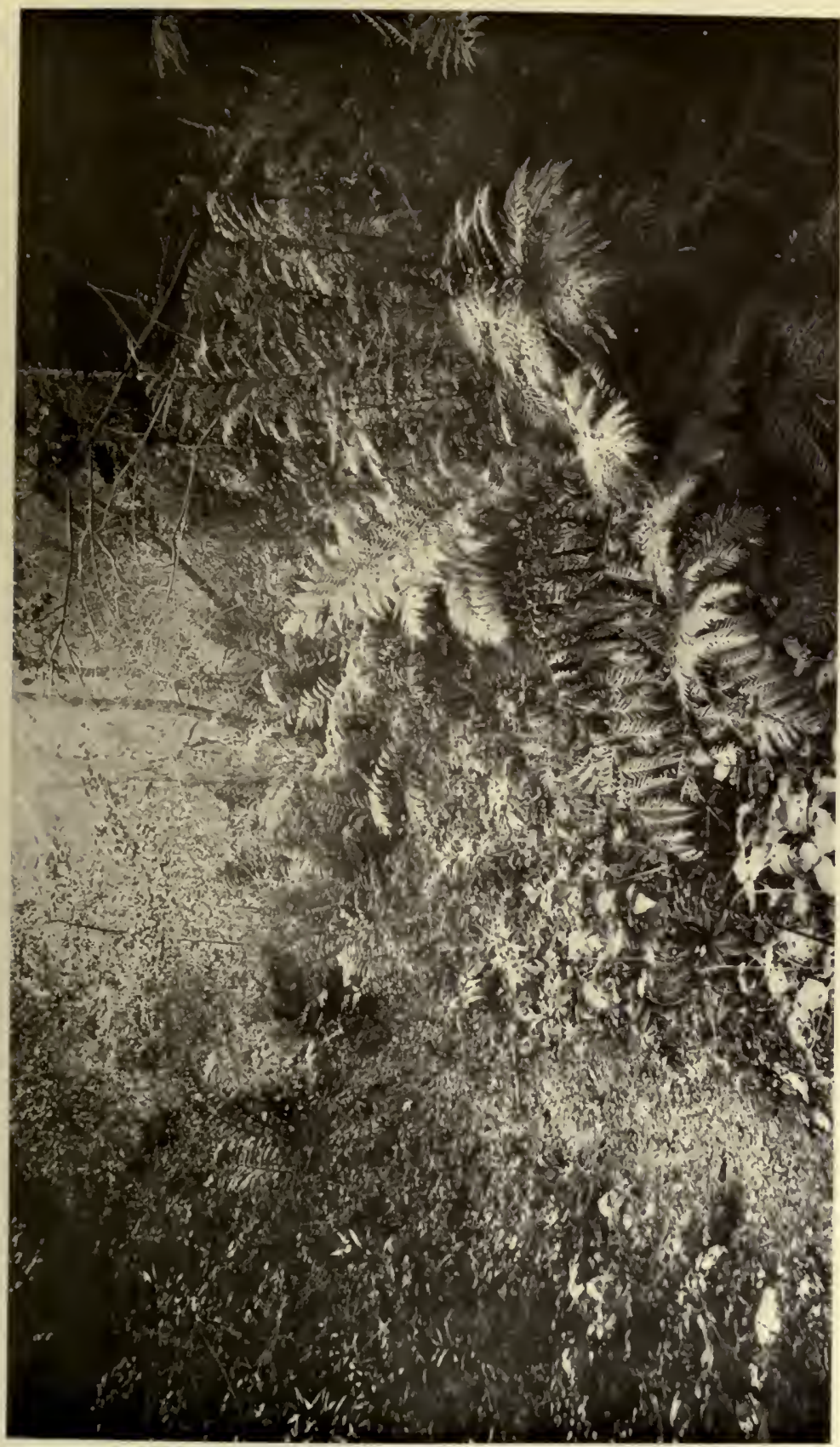

م. 


\section{A Rainbow in the Sierra Madre}

about a thousand feet to the mile. This leads to the wild and picturesque West Fork of the San Gabriel Cañon, and whether a burro with a pack can penetrate it depends upon the individuality of the burro and the effect the elements have had upon the stream during the past winter. The camp authorities will doubtless post themselves in the future as to the condition of this trail and the West Fork; the angler can be advised in Pasadena by telephone, and if the trail down the West Fork is not available, he can have his outfit shipped to Follow's Camp from Azusa, and make the descent of Mount Wilson in light marching order, with blankets and rations for two days. A better plan is to take a guide who will pack the light kit and leave the angler full play with the rod along this fine stream, with its thirty miles of fishing, which will bring him in two days to Rincon, where the stage can be taken for Azusa.

It is assumed that the angler of Southern California is a lover of mountain climbing, and this route is a constant delight to such an enthusiast. The view from near the pagoda-like observatory into the San Gabriel abyss is a revelation in itself-a deep gulf or rift worn out by the rush of waters. It invites the angler in a thousand tongues to descend and explore, and tosses back his voice in a marvellous series of echoes.

Around Santa Barbara and San Buenaventura in the Santa Ynez Mountains some charming trout streams may be found, which are now systematically stocked and protected. The Sespe, fed by cool springs and the 
drainage of a large area of mountains, is one of the most attractive streams in Southern California for the early trout fishing. From Los Angeles it is reached by taking the train to Fillmore, about fifty miles distant, from which the angler goes about five miles by team to Devil's Gate, reaching Pine and Coldwater creeks and the West Fork. If the angler desires to intercept the Sespe between its rise and the sea, he can go up the Ojai Valley from Ventura. Along this road, a fine trout stream flows, a constant delight to the stroller.

From Nordhoff, the little town in the Ojai Valleyone of the most fascinating bits of country in Southern California, with its big trees, its velvet-like carpet, its multitude of birds, and lofty hills all about,- - the angler can ride on horseback twenty miles over the mountains, coming out at the Sespe near Sulphur Springs.

Near here is the romantic Matilija Cañon; and at Santa Paula the picturesque creek of that name and the Sisar flow through a wild and attractive country, affording ideal conditions for the angler. Santa Paula Cañon is one of the most interesting in this part of the Sierras, and the accommodations at Sulphur Mountain Springs are excellent. The summit of Sulphur Mountain, easily reached from here, is the centre of a fine hunting country; deer, dove, quail, and trout being the special attractions to the stroller through the range.

The Los Angeles River as it passes through the City of the Angels is a river by courtesy at times, but after a rain in the mountains, it often runs banks full. 


\section{A Rainbow in the Sierra Madre}

Tracing it up, it winds through San Fernando Valley and merges into the Tejunga, its main source of supply, which with the Santa Clara River in the upper Soledad Cañon often provides the angler with fair sport.

Many of these streams that sink into the sand in places, as the Los Angeles River in the San Fernando Valley, and the Arroyo Seco, and seep along beneath the surface for miles, to appear again, are sources of constant wonder to the angler who knows only Eastern brooks that always hold their own in the open, and flow through fields of nodding flowers; but the California streams reach the sea at times in winter, though during the summer and fishing season they are often landlocked by sandy wastes.

The rainbow trout is indigenous to the California Coast Range cañon streams, and ranges from the Klamath down to about the Missions of San Juan Capistrano or San Luis Rey, and varies much in colour in different localities.

I have seen one from the Arroyo Seco upper pool that was a light olive-green, covered regularly from head to tail with small round black spots. Another trout taken in the San Gabriel was blue and had splashes of red upon the sides; the belly of pearl, with faint spots. The large fish in the streams of Santa Barbara, Ventura, Los Angeles, and San Diego now range from one to two and three pounds when sea run; but Sage gives the maximum weight of Williamson River trout as thirteen pounds, and Mr. W. H. Glass 
tells me that his largest rainbow, taken in Bear Valley Lake, weighed ten and one half pounds, while another weighed twelve and one half pounds.

The fame of the rainbow trout has travelled wherever rods are known, and the fish has been distributed far and wide, even introduced into England; and almost everywhere, it is said, retains its wonted vigour and game qualities. The open season in California is from April first to November first, and in San Bernardino County from May fifteenth to November first.

A feature of fishing in Southern California is the ease with which the mountains are reached. Los Angeles is but thirteen miles from the mouth of the Arroyo Seco, Millard, and other attractive cañons; the Ojai Valley, Santa Paula, or Santa Barbara streams are but a few hours distant, while the San Gabriel River can be reached from the city by train to Azusa in less than an hour, where a stage takes the angler into the mountains to any of the camps along these typical Southern California streams. The camps are at an altitude of several thousand feet, where hot weather is practically unknown; indeed, one of the surprises to the angler in this country is the summer climate: warm days come in trios and pass, but sunstroke and heat of the character that is experienced in Chicago, New York, and other Eastern cities is unknown.

The available waters of Southern California lakes and streams are stocked yearly by the State Board of Fish Commissioners with rainbow, Eastern brook trout, 


\section{A Rainbow in the Sierra Madre}

and cut-throat trout. Black bass have also been placed in lakes and reservoirs in Los Angeles, Orange, and Santa Bárbara counties. Too much credit cannot be given the Board of State Commissioners, as were it not for their constant efforts trout fishing would have been a thing of the past long ago in Southern California. Every year, every available stream is supplied. San Bernardino receives one hundred thousand fry per annum. The Bear Valley reservoir is constantly restocked, as are all the tributaries of the Santa Ana River and the San Gabriel, and those in the counties of Santa Barbara, Ventura, and San Diego. The Rio Colorado has been stocked with black bass at the Needles, and the sun-perch placed in the artificial reservoirs on the desert at Indio, Thermal, and Mecca. Bear Valley Lake contains the rainbow and the Tahoe Lake trout, and large specimens have been taken.

Dr. Benjamin Page, of Pasadena, who has camped in the splendid forests about the great lake, is the dean of the anglers and mountain lovers who fish here. $\mathrm{He}$ has cast a fly into every pool in the range, and has made some notable catches. One I recall, taken in the Bear Valley Lake in July, with rod and grey badger fly and helgramite bait, was two feet one inch in length, one foot two and a half inches in girth, and weighed seven and a half pounds. This fine fish, a Tahoe Lake trout, fought the skilled angler an hour and sixteen minutes before it could be brought to gaff, and was but one of a notable catch made by Dr. Page's party. 
The pools in Deep Creek, in the San Bernardino mountains, are of great beauty and size, often chiselled out of the rocky and literal basins of stone, flanked by stupendous masses of rock, down which the clear waters splash and foam, pouring from one great pool into another on their way down the stupendous slope of the range. Such is the lower Big Pool. The upper Big Pool, Deep Creek, is even more remarkable, if possible, for its water-worn rocks, the clearness of the water, and its melody where it falls in a level sheet; then striking a sloping ledge it bounds down into the pool, a mass of molten silver, carrying life and aëration into an ideal pool in the heart of the forest where the angler does not cast in vain.

This fine mountain stream well illustrates the possibilities of mountain climbing and trout fishing, abounding in long reaches of forest, tumbling down great distances in short periods, at once one of the hardest streams to climb, and one of the most beautiful and satisfactory to the lover of mountain life.

Deep Creek is an eastern fork and possibly the largest branch of the Mojave River, and can be traced into a desert second only to the Sahara in its terrors of heat in midsummer; hence, one of the most remarkable trout streams in the world for its contrasts. If any one should point out this dry river-bed in the desert as a trout stream, he would be laughed at, as it is a mere streak of water-polished stones overwhelmed by sand-dunes for miles over the desert, what water there is 


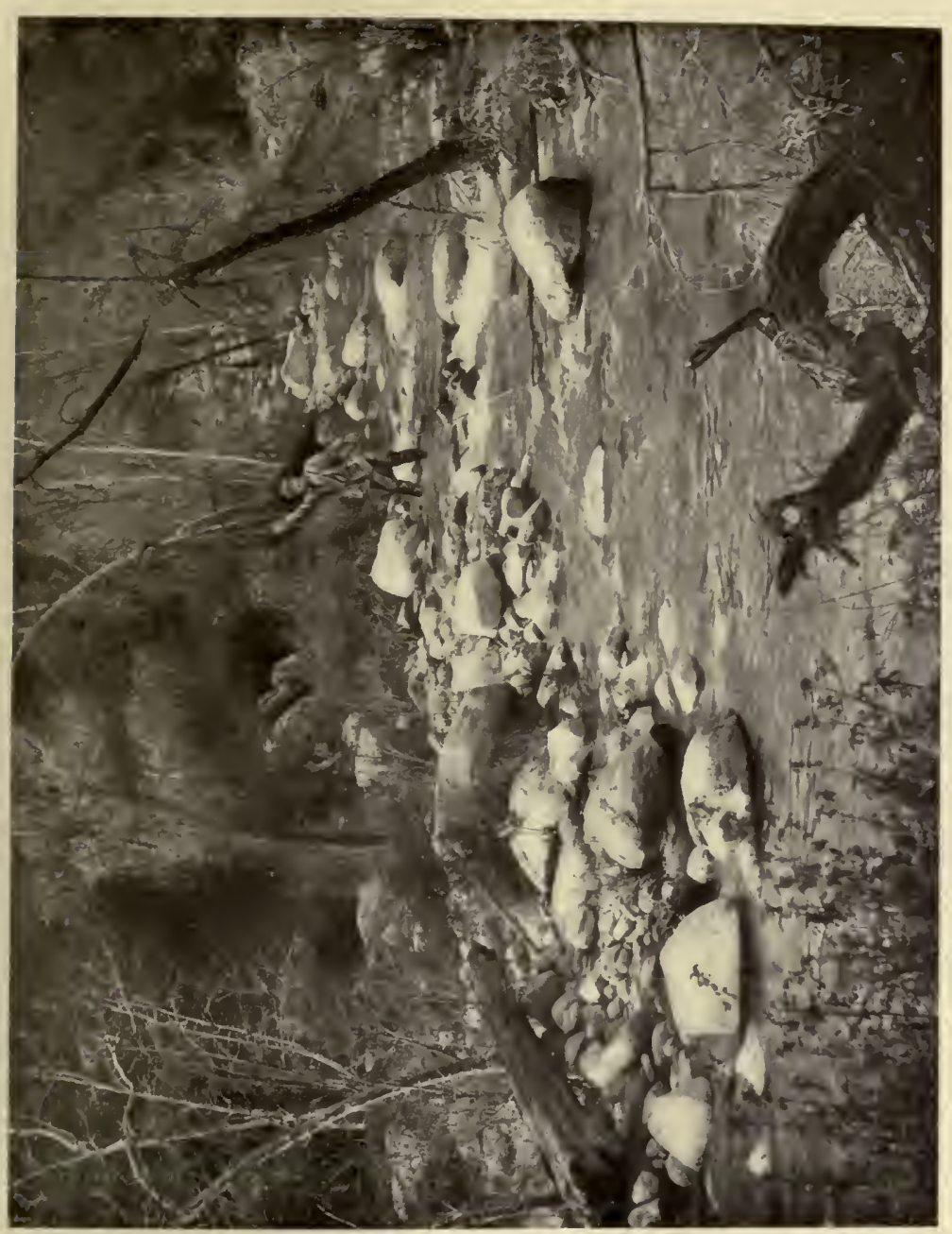

总 



\section{A Rainbow in the Sierra Madre}

being far below the surface or entirely gone; but if traced up to the foot of the San Bernardino range, that rises ten thousand feet above the desert, it soon appears and for miles climbs the Sierras as one of the most attractive trout streams in California, abounding in huge pools, and scenery of the wildest description, where the elements appear to have had full sway and have vented their fury upon rock, forest, and range.

The stroller along the picturesque shores of Southern California will find here and there peculiar lagunas, - small bodies of water separated from the sea by the sand-dunes, yet at high tide connected by a little channel that at other times is not always apparent.

These lagunas are often the mouths of the Southern California trout streams. There is one at the mouth of the Santa Ynez, near Lompoc, reached by steamer, stage, or rail from Santa Barbara ; one at Alamitos, 一and at Long Beach where the San Gabriel River reaches the sea; another at Venice, where the genius of Abbot Kinney has produced a beautiful town on water-way streets, after the Venetian fashion; another is found in San Diego County where the San Luis Rey River runs into the sea; and there are many others along shore; but the four mentioned are the mouths of rivers down which trout may reach the sea, at times, and in and about which is found the steel-head, supposed by some to be the sea-living form of the rainbow, but by others considered a distinct species. The steel-head bears some resemblance to the rainbow, but would never be 


\section{Life in the Open}

mistaken for it, at least in the south. In April and May it can be found about the entrance to some of these streams, and in the Santa Ynez has been taken weighing twenty pounds, leaping five or six feet into the air when hooked, and making a splendid and vigorous play on light tackle. 


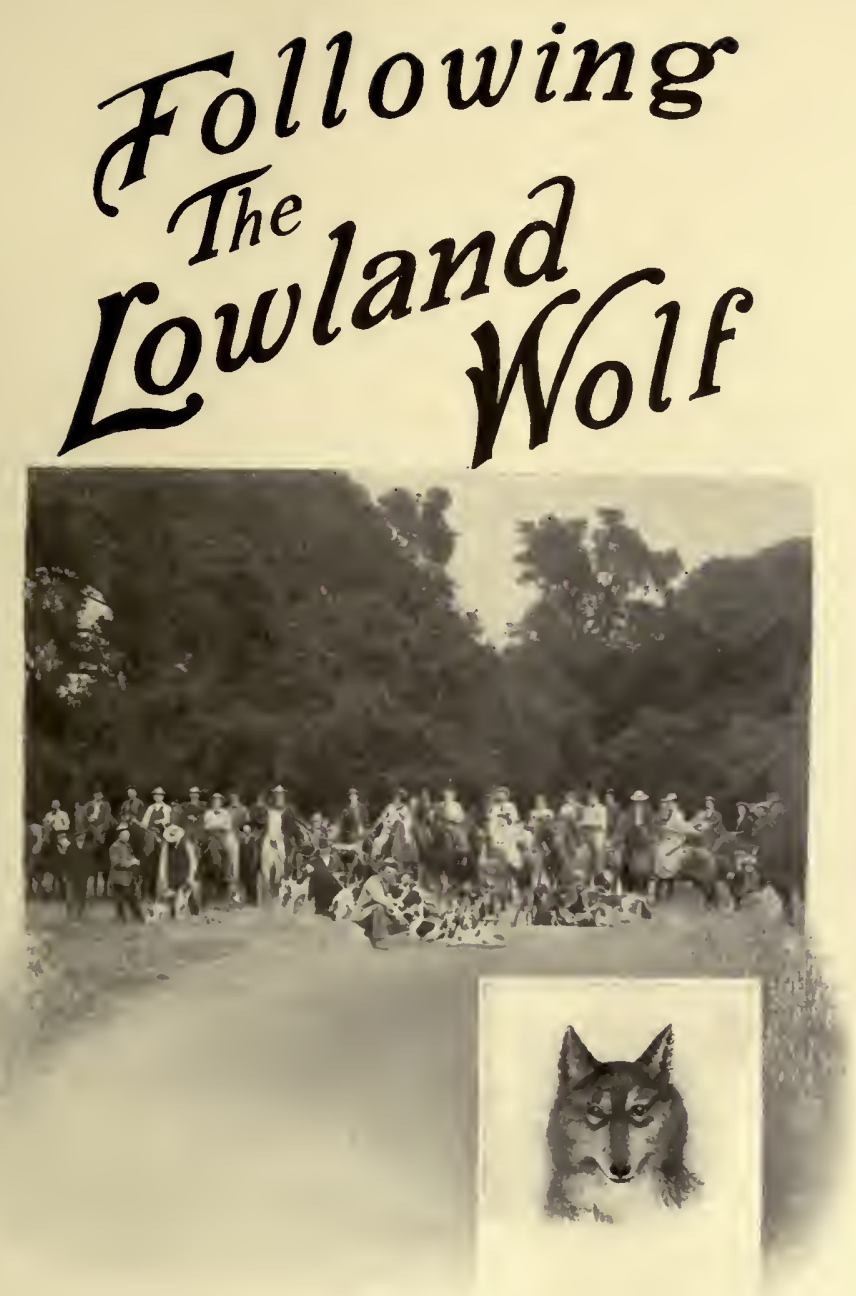





\section{Chapter VII}

\section{Following the Lowland Wolf}

$7 \mathrm{HE}$ meet of the Valley Hunt was at a certain oak not far from the edge of the Arroyo Seco.

1 At an early hour the soft melody of a horn came through the orange groves followed a few moments later by hounds and riders, the men mounted on high-pommelled Mexican saddles with a brave showing of silver and carved leather.

It was a winter morning in Southern California, and as the hunt turned to the south and rode through Pasadena the ground was silvered with heavy frost in places, the summits of the Sierra Madre were white with snow, and the sentinel peaks of San Antonio and San Jacinto, ten thousand feet in air, loomed up, white domes against the pink glow of the morning sky. You could see the snow flying on San Antonio, hovering like a cloud at its summit; you could see the big trees laden with snow on Mount Wilson and Mount Disappointment. Winter was abroad and visible, but here, mocking-birds, orioles, finches, song-sparrows, from 
every tree and bush sang of spring and summer. The blossoms of the heliotrope, banked against houses, filled the air with fragrance; roses piled high in great masses of splendid colour over doorways and verandas; the orange groves were white with bloom, and as the hunt left the town and struck into the open the full beauty of this California winter was seen. Fields of barley stretched away on every hand; acres of oranges and lemons, and groves of pom-pon-like eucalyptus. The roads and lanes were lined with green, and great stretches were starred in yellows - the faces of a small daisy-like flower, - while the Copa de oro was unfolding, releasing countless bees that had passed the night in these golden-tinted prisons along the mesa. It was winter in Southern California-winter among palms, bananas, and a host of tropical and semi-tropical trees. Yet the air was crisp and cool, as one might expect where the night-wind had caressed snow and ice on the slopes of San Antonio.

The Valley Hunt pack consisted of about fifteen greyhounds, built for endurance; tall, rangy, as large as deerhounds; some coming from Australian stock, that had hunted the kangaroo in the open reaches of that country; others having been bred to the hard work of taking jack rabbits in the great vineyards. Massed, they presented an inspiring picture, as they trotted along; their trim, blue-and-tan coats shining; their bright intelligent eyes glancing to right and left.

The game on this winter morning was to be the 


\section{Following the Lowland Wolf}

coyote or lowland wolf, the clever animal so familiar in the West. Only the day before I had seen the feathers of a turkey in the middle of a wide street; the ventriloquistic laugh of the coyote had been heard over the arroyo, at San Rafael, and the time seemed auspicious.

For a mile the horses walked to the south, reaching a point midway to the Mission Hills from Pasadena, then turned into the fields, which were open and clear to the San Marino vineyard, two miles distant. Here a stop was made and saddles re-cinched. When a clever California horse is cinched, he takes a long breath and resists, and as soon as the rider is mounted he "shrinks" to a remarkable degree; hence a second or often a third cinching is necessary before a long run.

The master of the hounds was now fifty feet ahead with the hounds, and the hunt moved on over the alfileria and burr-clover. It was still early, and a slight haze gave a mirage effect that was very deceiving. A buzzard appeared like a roc, and a distant cow loomed up as large as an elephant. Suddenly something else appeared and the master of hounds pulled rein. About three hundred feet ahead, standing on a little rise, an object that looked like a gigantic dog was silhouetted against the sky. It stood half turned, its big ears up. Then the hunt moved slowly on, creeping up to it, while it stood and watched, never moving. Soon it resolved itself into a coyote that eyed us with evident contempt, nor did he move until the master of the hounds spoke to the pack and they dashed ahead. 
Greyhounds, except in rare cases, have no scent, at least it is of little use; they run by sight only; and as the master spoke a familiar word that in the universal language meant game, each dog raised his head and looked eagerly forward. Some leaped bodily into the air and glanced around quickly ; then, all seeing the dim form ahead, lengthened out and rushed on, followed by the roar of pounding hoofs, the clanking of snaffles and chains. There is nothing quite like this sudden leap into action of twenty or thirty horses as eager for the sport as their riders; and that they enjoy it every wolf hunter will tell you.

The coyote held his post for a second, then, seeing that what he might have taken for a lot of herders or a herd of cattle were coming his way, he swung around, dropping his tail and head, broke into an easy run, and slipped down the side of a wash where the white sand of a little arroyo wound away, flanked by prickly pear and sage.

Over the bank went the dogs, spreading out like a fan by instinct, followed by the hunt, the knowing horses settling on their haunches and taking the slide as a toboggan, then lengthening out into long lines in the wash. Suddenly the coyote dashed to the left, up an old trail he and his ancestors had made, and regained the mesa ; the hunt going on to some break, and losing by this clever trick. Once up on the plain again, the hounds were seen well bunched, and the hunt now stretched out, the good horses taking the lead, the poor 


\section{Following the Lowland Wolf}

ones already discomfited, as it had been literally a runaway from the start. The ground was hard; it had not been ploughed for several years, so afforded the horses a vantage ground, and a number rapidly closed in on the hounds. The master, mounted on a fine sorrel, "Del Sur," was riding directly behind the dogs, his eye gleaming with pride at their movements, their splendid action. Near him were four or five riders, careful not to overrun even a slow dog, giving them the field. The pace was furious, - and over three miles of level country stretched away to the Mission Hills, the home of the coyote. He must be run down before they are reached. All this time, or since the coyote has dashed out of the arroyo, the dogs have been running "on orders." They have lost sight of the game, but the master of the hounds has the wolf in his eye, a gray spot shooting along like the wind, and he directs them, the hounds with wonderful prescience taking the direction of his horse and turning as he shouts.

The hunt is now stretched out over half a mile. The sun has energed from vermilion clouds, and is flooding the valley of San Gabriel with light, illumining the lofty snow-caps with ineffable glory; while all along the range a crimson light is stealing, and deep purple shadows are creeping into the cañons like weird spectres of the night that fear the light of day.

A shout from the master of the hounds, the dogs sight the game, and, still silent, stretch out, working like machines. If you are well to the fore you will 
hear his exuberant expressions of delight - "Well done, Mouse"; "Good Chiquita"; "Good boy, Ramon" - as the dogs shoot ahead. The ground is dangerous ; there are badger holes, washes, and pitfalls made by squirrels, out of which owls fly as we rush by. You put your reliance on your mustang, and watch the dogs and that spectral gray spot far ahead. The pace is increasing; the dogs are warming up. Your mustang has the bit in his teeth, and you remember to have read that only a race-horse can keep up with a coyote; but this pace and country would have killed a well trained racer. Your clever, wiry horse leaps every hole; he knows them by intuition; and takes everything as it comes.

Suddenly the dogs make a sharp turn; the coyote has changed his pace and we are well in. Old Ramon has forced the turn. How they run! like machines, every movement telling of grace, springs of steel, and beauty of motion. Across a rough field we go, through a high mustard patch, then out into a narrow road. The best horses are well bunched behind the dogs, and like a rush of mighty wind the hunt sweeps down the road, gaining on the coyote at every leap. The hounds had spread out and looked like streaks of dun and blue. They appeared to make no effort to see, but that they were pulling up on the ghostly form was more than evident. Occasionally I saw the game turn and glance over his shoulder, then with his big ears well back he shot on again at marvellous speed. 


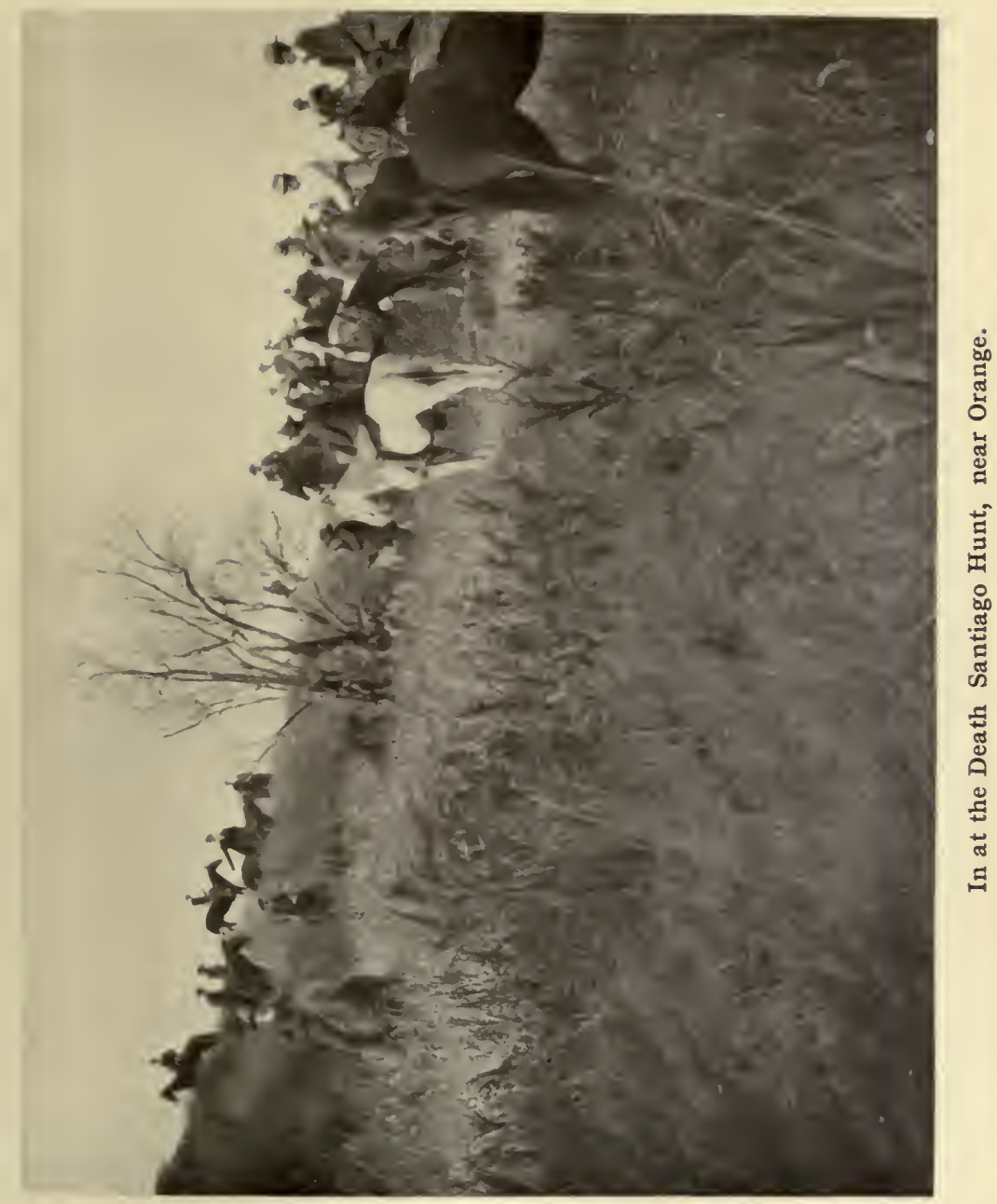





\section{Following the Lowland Wolf}

The dogs relieved each other in running; one would take the lead for a few moments, then drop back as another surged to the front, the effort of keeping to the fore being exhausting. But gradually they drew ahead. Suddenly the coyote swerved, turned sharp around, and dashed down into a narrow wash over which we went; some caving in the treacherous earth; others cleaving it; the dogs piling in, then on frantically as the coyote appeared farther down.

The trick was well played, the game gaining two hundred feet, and then it was a race for the foothills. It is the unexpected that happens. Suddenly a barbwire fence appeared. In some marvellous manner the coyote squirmed beneath it and sped away to the hills, while the hunt lined up and the master of the hounds leaped to the ground to prevent the hounds from cutting themselves in their desperate attempt to follow. The horses had made a splendid run of three or four miles at racing speed, and after a rest the fence was opened and the hunt continued.

The coyote by this time was in the Mission Hills, so the riders and hounds followed up one of the cañons that cut through the range, reaching the south slope; then, in pursuance of a definite plan, spread out in a long line and mounted the steep slopes, using the sheeptrails as pathways. The hills were like green velvet mounds, and part of a range called the Puente or Mission Hills, running parallel with the Sierra Madre, and farther down growing larger, near Santiago Cañon, there 
rising into a snow-capped mountain. The plan was to sweep the range from behind and force the coyote down into the open valley again. The summit reached, the hunt extended along the divide and various peaks for a fourth of a mile, and as the coyote had not been started it was assumed that he was lying in some little cut on the north slope below.

No fairer view could be imagined. Below, the valley of San Gabriel, a winter garden : vineyards, groves of the olive, lemon, and orange, great squares of eucalyptus, groves of the black, live oak, with lofty palms here and there, and beyond, as a background, the snow-capped Sierra Madre.

I had dismounted, and stood wiping the dust from the face of one of my own hounds, and assuring her of my complete satisfaction and admiration, when my eyes caught a dun-coloured object, the coyote, not two hundred feet down the slope. He seemed by intuition to know that I had seen him, as he stopped; and so remarkable was the protective resemblance, so happily did he melt into the gray of the wash that I almost lost sight of him. He seemed to dissolve into empty air. I whispered the situation to the lady by my side, assisted her into the saddle, and just at that second, before I had time to toss the reins up over her horse's head, my dog and horse saw the coyote. I was jerked into the saddle in a miraculous manner, and we plunged down the hill. A second before, every eye was riveted on the picture that spread away hundreds of square 


\section{Following the Lowland Wolf}

miles; now with a clash of Mexican bits and stirrups, shouts passed along the line, and the hunt was on, a wild race for the low country.

These hills were steep for anything but a Catalina sheep pony, and the normal, sane way to descend was by the myriads of sheep trails that had worn into the hillside like the cross waves on a sea beach. But the coyote disregarded this and ran directly down the precipice, the dogs following, and then those whose horses took them.

I have an indistinct recollection of slipping, sliding, almost rolling down the slope, of reaching the open and leaping a yawning ditch into which a hound had rolled; of seeing close behind me the lady with no reins; then we rushed down into a ragged wash, up the opposite side, and there was Don Coyote, one hundred yards away, running for his life. Our horses were fresh, and in a few moments we were on the flank of the silent pack that swept along like a single dog - a terrible menace to the dun-coloured thing growing nearer and nearer. There was madness in the race-the mastering of space by the dogs, the running of the horses that could not be stopped, the whistling of the wind, a desire to take desperate chances and be in at the kill-which sent the blood whirling through the veins.

The coyote ran directly over the back track and we gained every second. By chance and good fortune my horse carried me up with the hounds, and for the last quarter of a mile we raced to the finish, the young lady, 
the master of the hounds, and myself, the rest of the hunt on the hillside some distance away. Up to this time not a sound had come from the pack, and as we drew nearer I leaned down and spoke to my own dogs and the master of the hounds to his. We called on them for a supreme effort, and as the coyote turned they fell upon him, and our horses rounded up so suddenly that $I$, in the effort to dismount, went to the ground, but luckily upon my feet. Pandemonium broke loose: wild cries from the wolf and sharp staccato yelps from the hounds that now, and now only, gave tongue, while above all I could hear the sharp click of the coyote's teeth. Thin-coated or short-haired dogs are easily disfigured by a coyote, and every time that shining row of teeth clicked, a good dog was injured. As I reached the excited throng, to save them as much as possible, the master of the hounds plunged into the roaring, yelping pack, and seizing the wolf by the throat, lifted him high in air.

It was heroic, but heroic measures were needed; and the next moment my ordinarily quiet friend, Dr. J. de Barth Shorb, with a heavy crop, had given the coyote his quietus, and thrown him to the dogs. The coyote when attacked had thrown himself on his back against the hillside and met all comers with a resistance born of rage, desperation, and despair, and several dogs were badly cut by his savage snapping. Dogs, huntsmen, and coyote presented a sanguinary appearance as the rest of the hunt came in, some, nearly ten minutes later, to find the young lady wearing the brush. 


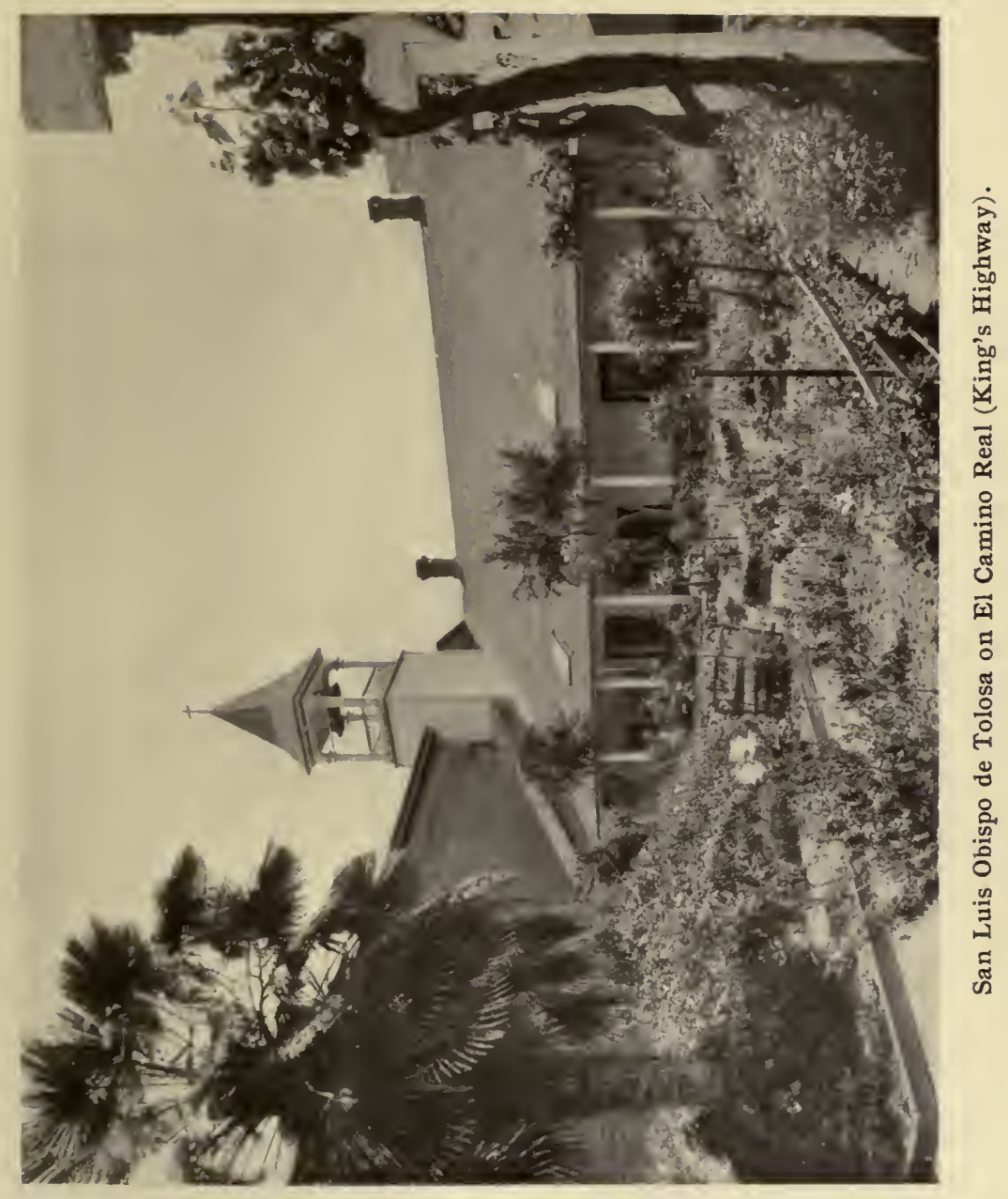





\section{Following the Lowland Wolf}

Such was a typical run across country of the Valley Hunt in the old days; a club which the author founded in I886 and which is still in existence, though the crosscountry riding is restricted about Pasadena and other towns, due to the settling up of the country. Where, or near where, the coyote was killed, is a forest of eucalyptus, and houses and fences stop the way; but there are thousands of acres beyond the towns where identical sport can be had to-day, coyotes coming out of the range every night and yelping singly and in concert.

As we rode out that morning a guest from one of the Eastern fox-hunting clubs remarked that as there were no fences to jump the sport must be "rather slow." I did not dissent, but some time after the kill our guest came in, and after congratulating the young lady who had made a ride which for daring, I venture to say, is seldom equalled by a woman, he turned to me and, laughing, said, "I take it all back about the lack of excitement; but that run was n't hunting, it was suicide. I never would have believed that a horse could go down such a precipice on the run."

It looked dangerous to a man habituated to the beautiful pastures and level stretches of country of the East where bad washes, badger and squirrel holes are unknown; but to a California horse with a soupçon of mustang in him, a horse that enjoyed sport and knew all about it, it was nothing, and even this was a bagatelle to some of the riding I have seen among the sheep 
herders who round up sheep in the steep cañons of Santa Catalina and Santa Rosa islands. The secret was that the wiry horses were as sure-footed as goats, even when running at full speed along the side of some cañon.

The country may be dangerous for indiscriminate hard riding, but not for those who know and are fond of it; and in ten or more years of cross-country riding with a large field, the Valley Hunt had no serious accidents, and few of any kind. One is worth mentioning for its extraordinary nature.

The hounds were chasing a coyote near this place one morning, possibly twenty ladies and gentlemen following, nearly all going at full speed; by that I mean many of the horses were almost beyond control. It happened that I was with the master of the hounds in the lead when we turned into a lane, which came out on to a new road which we supposed led to open country; but the barb-wire fence fiend had arrived unexpectedly, and we came on to his handiwork with a rush. I saw it and shouted back, and the hunt succeeded in stopping their horses; but the coyote squeezed under the lower wire, not ten feet from us. The master of the hounds could not stop his horse which struck the fence, which bent and threw him completely over. I had taken the left rein in both hands, exerting all my strength to either turn my horse or throw him, and the clever animal, seeing the extraordinary flight of his companion through the air, turned, settled back, as a cow horse will 


\section{Following the Lowland Wolf}

to throw a steer, and stopped, while I went on, landing on my feet in the soft earth in a wash from which I crawled through the fence to lift the master of the hounds, who was slightly stunned but wholly uninjured. But the horse-he was lying on his back with a double turn of barbed wire about his hoofs, holding him in the seriocomic position in which oxen are placed for shoeing in Mexico. He was immovable, but, remarkable to relate, almost uninjured. Some one hunted up a blacksmith down the road, who came and filed the wire, releasing the animal, which had but a few scratches.

$\mathrm{He}$ had turned a complete somersault, and was locked by the wire, head to the back track. Turning a somersault with a horse is a unique experience, a pastime which I have indulged in and described elsewhere, but I cannot commend it even in Southern California.

The coyote, as game, still holds its own in Southern California and the south-west in general. It is supposed to be a menace to the rancher, hence there is an excuse for the quest aside from sport; but accepting the latter as legitimate I can conceive of no pastime more exhilarating than this. An essential, at least to my mind, to true sport for large game is a sharing of chances with it. To go out with a rifle and shoot the coyote would be to descend to the level of the pothunter, but to hunt one of the swiftest of wild animals in the open, follow it on horseback, taking the country as it comes, is fair and honest sport to be commended; a sport in which the rider takes greater chances than the 
game which often escapes and leaves a worn-out hunt and pack to file home, while he, Don Coyote, watches from some elevated point with grim satisfaction, as some one in that cavalcade keeps turkeys, or chickens, and turn about is fair play.

I can frequently find the tracks of coyotes in the hills within rifle-shot of my house in a city of twenty thousand inhabitants; hear their insane laughing, yelping cry across the arroyo, and one coyote has so penetrating, so ventriloquistic a laugh that innocent people have been terrified, believing they were menaced by a pack of wolves; but investigation would have shown that all the noise came from one small, undersized coyote which sat on a rock baying after his fashion at the moon. The coyote is a wild dog that breeds with domestic dogs, and the big-eared issue is often seen in Mexican camps in the outlying districts. Hounds will often refuse to attack a female coyote. I once chased one several miles and after a long run worked my hounds to within twenty feet of the game and then called on them to go in. They closed in, and my best hound ran alongside the coyote - which snapped at him - refusing to attack. This was entente cordiale with a vengeance. I whipped the dogs aside and finally ran the animal down to discover the cause: the coyote was a female. There was but one thing to do; I could not be outdone in courtesy by my dog, so Donna Coyote and I parted company.

Southern California, or the best part of it, consists of small valleys and foothill mesas, intersected every- 


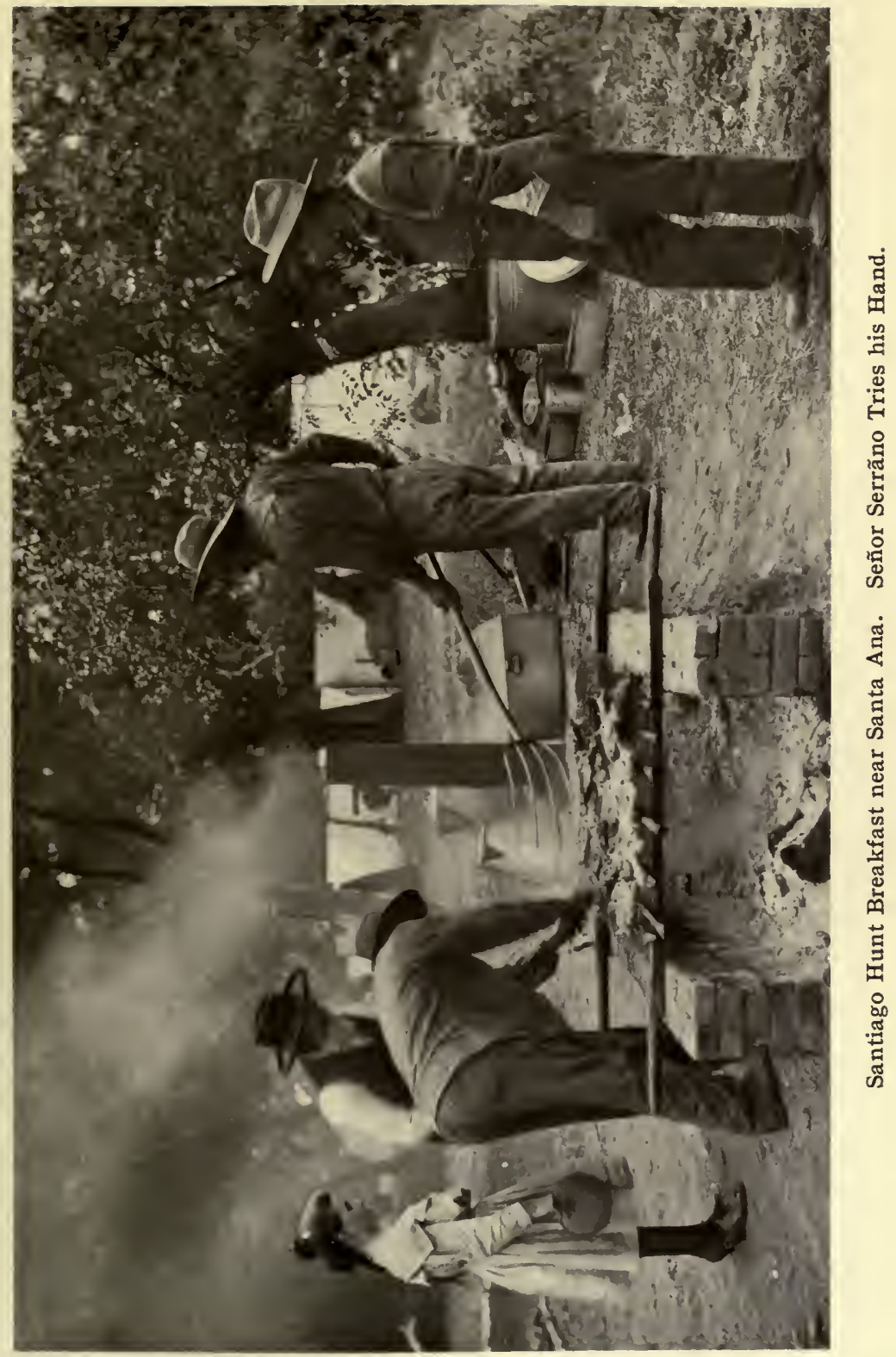





\section{Following the Lowland Wolf}

where or surrounded by hills and mountains, down the sides of which lead washes and runways from a foot to twenty feet deep. The coyote lives in the foothills and on the slopes. Here he has a den weathered out perhaps by the wind; here he lives during the day, looking down into the rich valleys and the haunts of men. As night comes on, and the shadows deepen and take on purple hues, when the heavy sea fog comes in along the Santa Monica range, or up the bed of the Santa Ana, he steals down the cañon and follows the shining sands out into the valley, where he takes up the scent of hares, and with his mate or mates runs them down; even a melon patch is game for him. He stands not on the order of going, but slinks about like a ghost; now sending out peals of demoniac yelping laughter from an orange grove, then heard half a mile away, setting the dogs of towns and villages barking and the cocks to crowing. In the morning I have visited the runs, the little and big washes that were smooth the night before, and in the round dog-like footprints have read the story of the night, the coming and going of not only coyotes, but wildcats and raccoons. The coyotes come out into the open at night, in cultivated places, returning at or before sunrise, and in hunting them it is well to begin at some foothill country, line up the hunt, and sweep out into the valley where some belated foraging coyote may be met trotting up the white sandy wash toward home. The Mission Hill range, which forms the boundary of the San Gabriel Valley to the south, is 
the home of the coyote, especially where it reaches to the south and east and approaches Mount Santiago; the coyotes having the San Gabriel, Pomona, and other valleys on one side, and the level country reaching down to the Pacific on the other. Here, twenty miles from Santa Ana, the Santiago Hunting Club holds forth, and on the San Gabriel side one may hear the musical baying of the hounds of the Maryland Hunt Club of Pasadena.

Orange County presents a very attractive hunting country, with an abundance of game, long reaches of well-wooded and sloping lands covered with live oaks, picturesque cañons filled with trees-all illustrating the charm of life in the open. Many of the hunts of this club cover the entire day, and at night they come into the big camp with coyotes, foxes, and wildcats hanging from the saddles.

The coyote has a wide geographical range, from Costa Rica to Athabasca, and from the central Mississippi Valley to the Pacific Coast, not being found on the islands. On this vast territory about twelve species have been recognised, and all over California they afford exciting and novel sport. 


\section{chore and Other Birds}
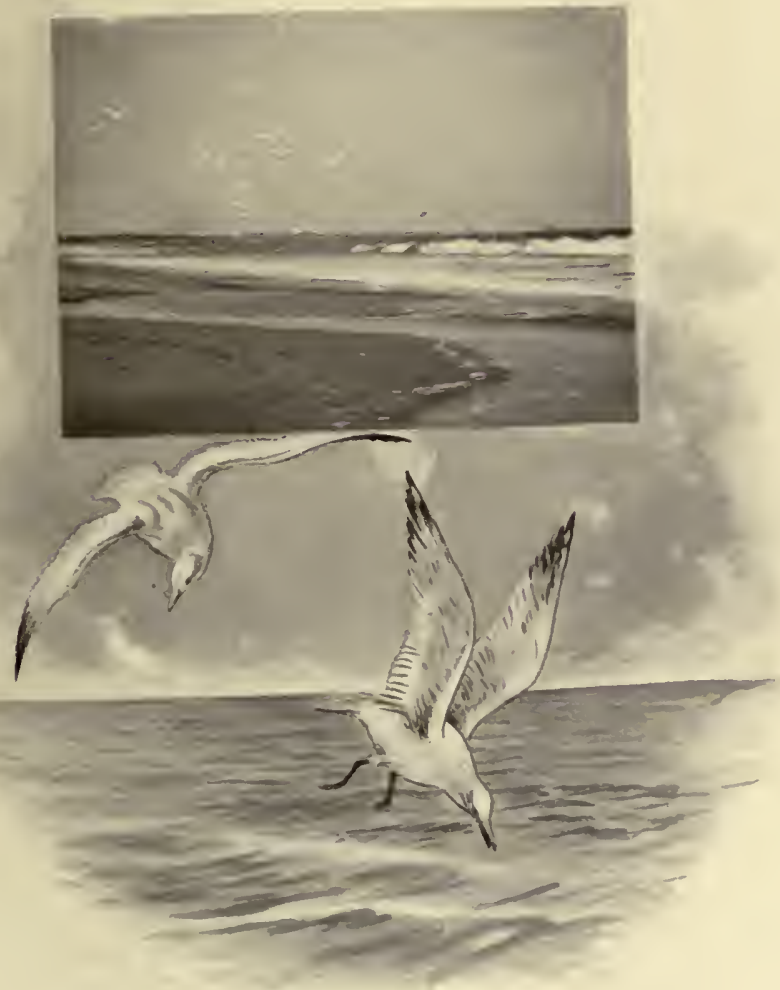



\section{Chapter VIII}

\section{Shore and Other Birds}

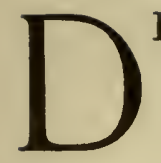

ESPITE the monotony of California beaches, the interminable wastes of sand and shifting sand dunes, they have a charm in their animal life. Near Santa Monica the mountains dip into the sea, and there rocks are seen, and again at Point Firmin; but from here until you reach the Laguna country, or below Newport, the long lines of white sand hold for miles, against which the sea pounds, tossing the spume high in air to be carried inland over fields of flowers.

The beach is worn by the wind into marvellous shapes and is ever changing. Look at it in early morning before the west wind rises; its surface is a biological record of the night. It is covered with footprints and mystic signs. Crabs have crossed it; snails have left a silvery trail; sea birds have stopped here, and this strange mark is the flipping of the wings of a laughing gull as it flew along just above it. Throngs of shore birds seem to have paraded along the sands, and 


\section{Life in the Open}

these big impressions have been made by a vagrant band of sea lions that passed the night here and went to sea at early morn.

But wait until the night wind drops and the great furnace of the desert begins to call the wind; every trace and footprint of the night is effaced. Little rivers of sand come running along the surface, filling every crevice, climbing up against the ice plant and verbena, and threatening the white flowers that lie along the sand. The pink faces of the shore verbena almost disappear as the wind rises; and so the story of the night passes and a new one is told.

The beach has a constant following of shore birds. Laughing gulls parade it, acting as scavengers, with gulls of several kinds ; just above is the least tern, eying us furtively, a delicate, beautiful creature like a spirit of the sand. Here I have found its nest along the dunes, and at one place, near Laguna, the bird had collected the richly coloured shells of the Donax, with which it formed a pavement and deposited its eggs upon it.

The California gull, the royal tern, Foster's tern, and many more catch the discerning eye of the stroller; and as he walks along the sands there is a constantly rising silvery throng of small beach birds that fly out a few feet and seem to become a part of the foam and disappear, to as suddenly come in and alight ; running along and dotting the soft yielding sands with their footprints.

Lying on the dunes near a point, one may see the American avocet, the black-necked stilt, and the marbled 


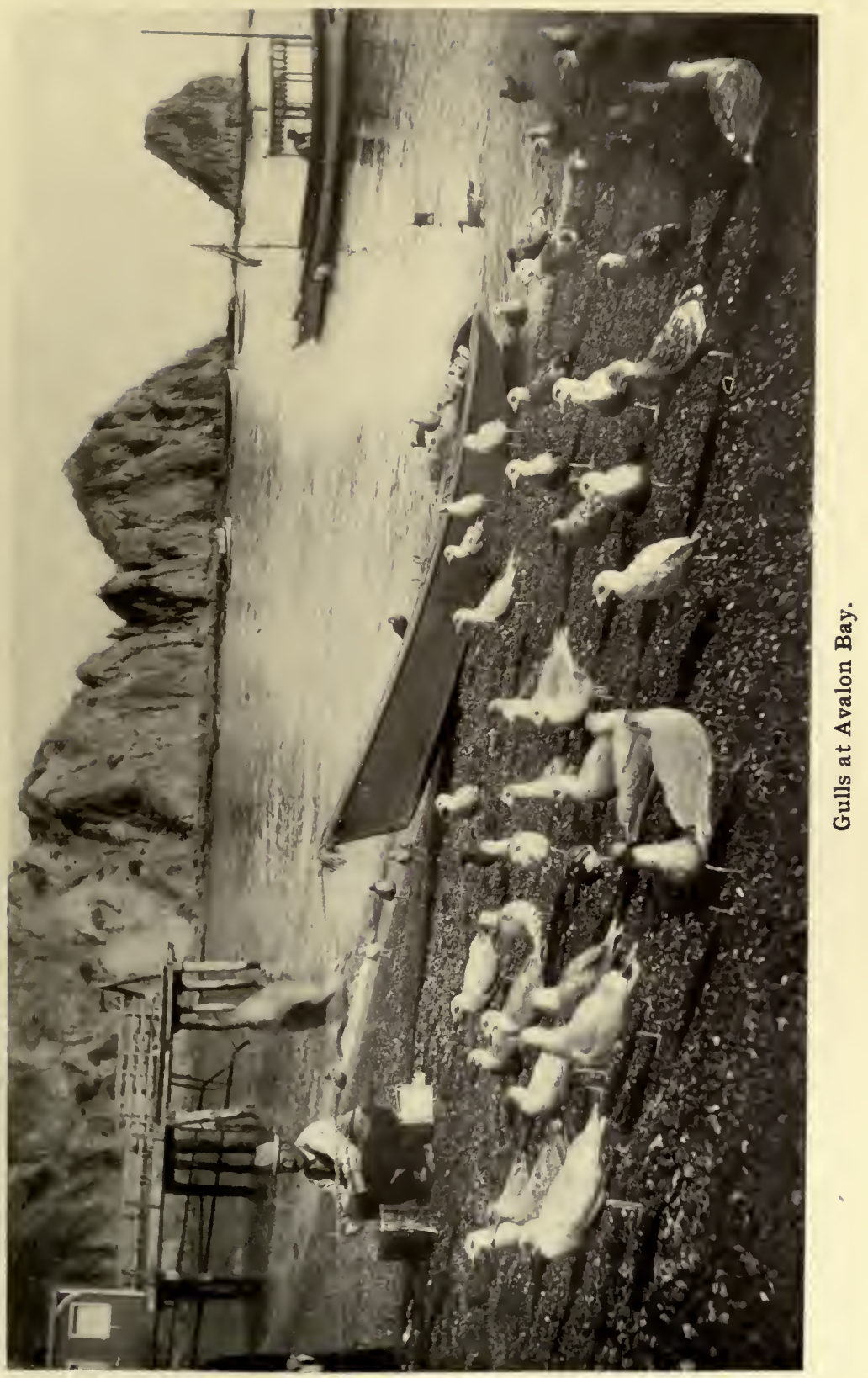





\section{Shore and Other Birds}

godwit; and over on the laguna side, Wilson's snipe and the long-billed dowitcher. The great flock that comes whirling along between the breakers and the shore, gleaming like silver, disappearing as it turns, is the western sandpiper. As they drop down, each bird runs along the beach a few steps, with wings lifted, as though posing for its picture reflected in the water. Here are the sanderling and the marbled godwit, standing by a mass of dead kelp; the western willet goes whirling by ; and among others you may recognise the tattler, spotted sandpiper, black turnstone, and several fine plovers; not all seen in one day, perhaps, but adding to the attractions of some wandering trip along-shore.

At San Clemente, Santa Catalina, and other islands you may see a variety of sea birds, attractive if not game,- - those which affect the island rocks and have no interest in the sands.

The best places for shore birds are where there are long stretches of beach and sand, behind which are pools and sea swamps, which afford mud flats for such birds to feed upon. Here one may see the great blue heron, the least bittern, and at times, farther in, the wood ibis, that has a penchant for barley fields and rolling mesas near the sea.

The cañons that reach away from the ocean afford fascinating nooks and corners for birds of many kinds, as here the valley quail comes almost to the beach; and around Santa Monica and the Malibu I have seen the great California vulture or condor, that nests in this 
range, and even as this is written the daily papers picture a renegade with his game, shot in this range near the sea, a splendid vulture, one of the last of the tribe, doubtless, in Southern California. In these cañons we see great flocks of mourning doves that flutter along the sands with musical flight, while at intervals bands of splendid band-tailed pigeons come down to breathe the soft air of the sea as it flows up the cañons.

If the sportsman wishes this game he should watch the mountains, and after a heavy snow-storm, when they are well covered down to the three-thousand-foot level, go to the great open ranches and fields at the base of the range, where he will see this fine pigeon, evidently driven out of the range by the snow. I have seen hundreds on the Hastings ranch, in the San Gabriel Valley, at such a time, and doubtless many such flocks could have been found far down the range.

Camping in the mouth of some big cañon, as the one at Santa Monica, Laguna, or San Juan, affords the lover of nature varied opportunities. A few steps up the cañon you find sycamores, cottonwoods, and live oaks in sight of the sea. In the chaparral are humming-birds; bright-eyed lizards glance at you from every stone pile, and the sly gopher pushes up his mounds as you look and ventures out of his hole perhaps to show you how he can run back and hit it, tail first. The fields are filled with ground squirrels that only take to trees in dire necessity; and at night a little leaping jerboa-like creature comes prowling about, while 


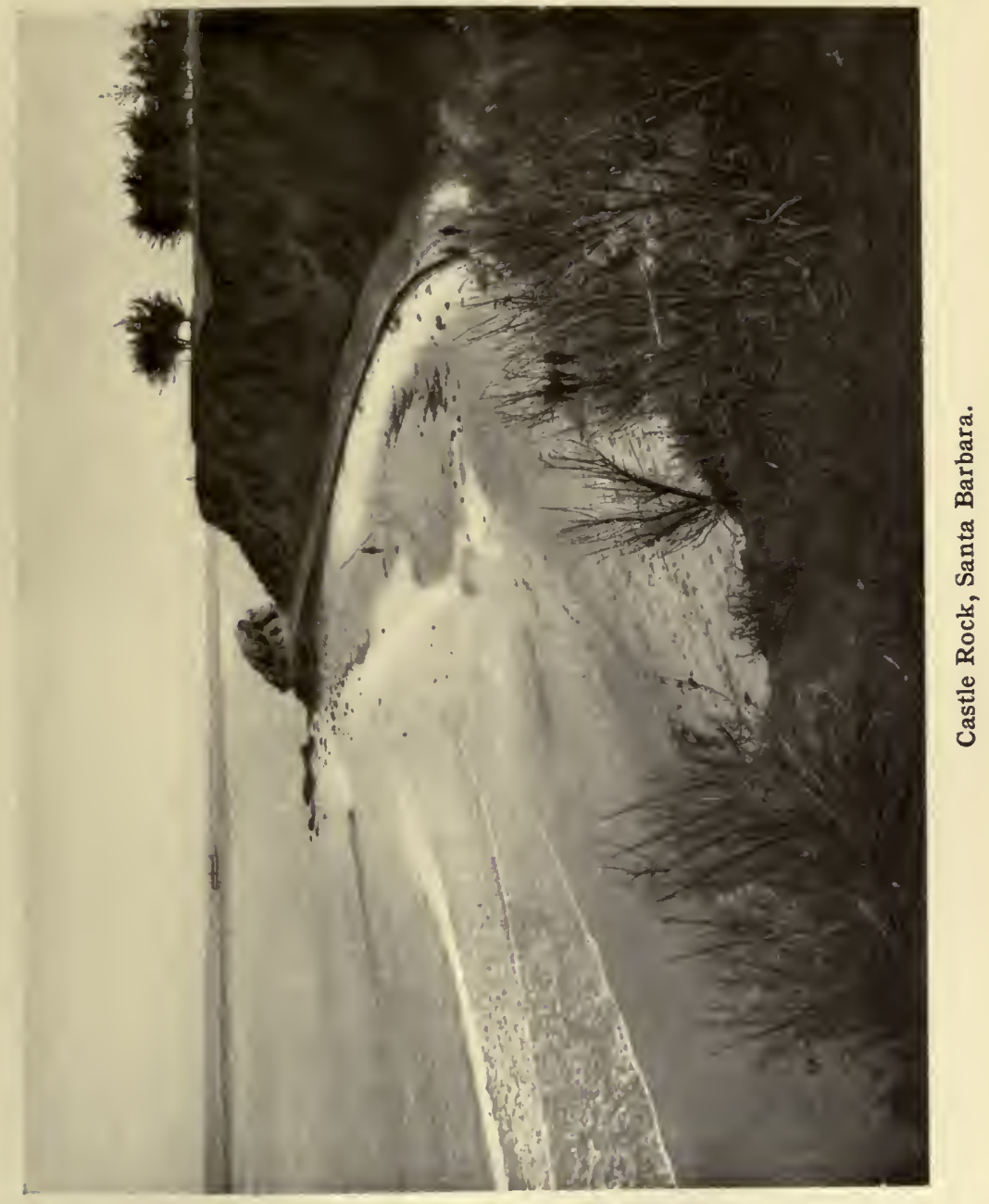





\section{Shore and Other Birds}

the wood-rat boldly ventures into camp or lodge and robs it by the light of the moon. In almost any cañon you may find the nest of this fascinating little creature; a mass of twigs and dead leaves, generally on the ground, but at times in trees. When chased and put to flight, the rat, which bears a resemblance to the common rat, takes to the trees, and leaps from one to another with perfect ease. A wood-rat which I kept as a tentative pet for a while would leap from a table to my desk, a distance of four feet, and a more inquisitive and thieving creature it would be difficult to imagine. Its robberies were bare-faced and open, and as I watched it one day it took a cigar from a box and hid it, then cut off a red rose larger than itself and pushed it into the hiding-place after the cigar.

On the beach near the cañon you may see the print of the raccoon, and possibly the clever animal himself. In fox-hunting the dogs occasionally catch them.

At night along the sands may be seen at the mouth of the cañon a beautiful little raccoon-like creature, the bassaris, with a bushy ringed tail and large expressive eyes. There are numbers of bats-one very large,-a great variety of small birds-thrushes, robins, orioles, kinglets, wrens, warblers, swallows, ravens, sparrows,an endless procession that fill the cañons with song, while the ranches with their orchards attract other and different birds. If game is hard to find along-shore, there is the compensation in a variety of beautiful forms always in sight. 



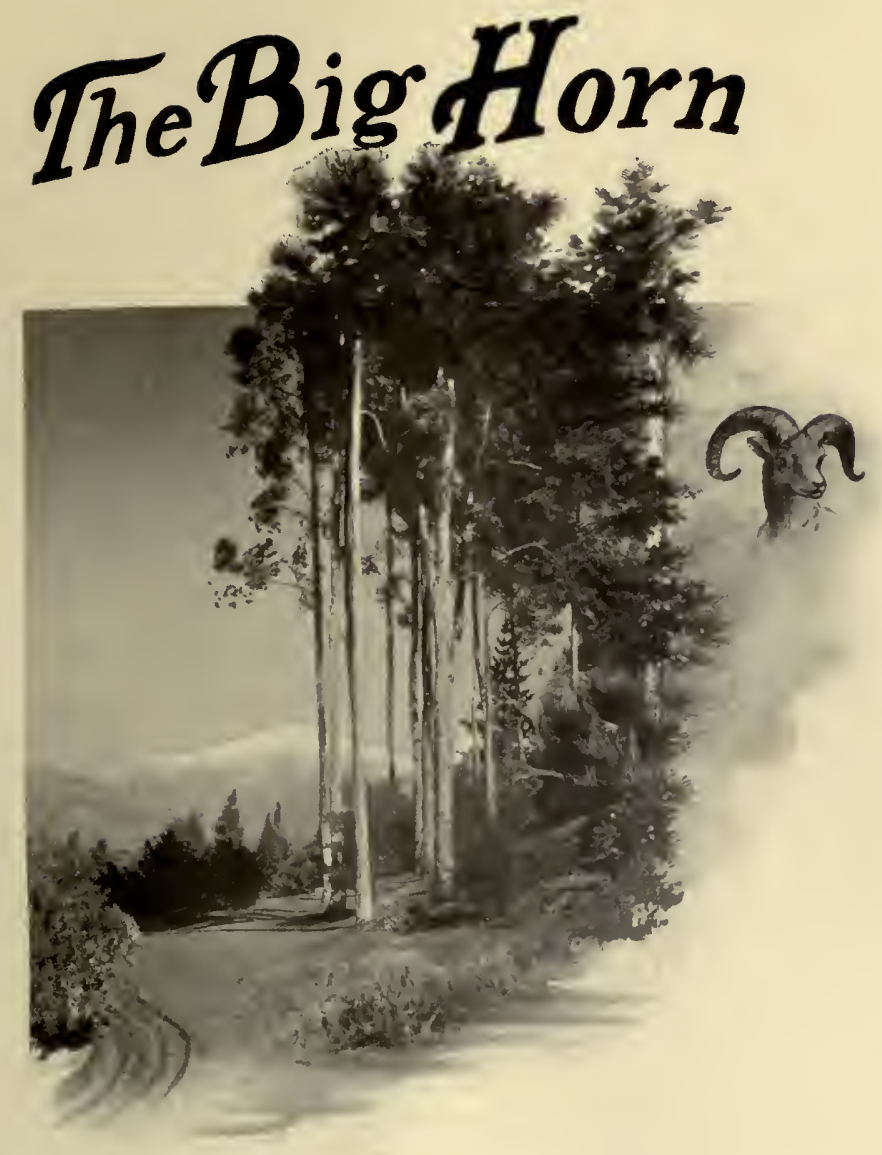





\section{Chapter IX}

\section{The Bighorn}

VU may at least look at bighorn sheep in California, and in attaining the glance you will climb some of the highest slopes of the southern Sierras. There is a band of bighorn sheep on the slopes of Mount San Antonio unless they have been killed recently; and others have been reported on Grayback or Grizzly peak, on San Jacinto, or other lofty summits from eight to eleven thousand feet above the sea. But they are protected by law, and, as I have suggested, can only be looked at or photographed, which, after all, is the most satisfactory method of hunting game that every intelligent American knows is being exterminated.

If the bighorn cannot be had in Southern California it can be found over the line on the peninsula, not many miles below San Diego or Coronado, where one may take the steamer for Ensenada and there procure guide and pack train for the lofty mountains which form 
the spinal column of the country between the Pacific and the Gulf of California.

Lower California is but an extension of Southern California, growing naturally warmer as one proceeds south; as Agassiz said when he visited it on the Hassler Expedition, "It has an almost perfect climate during the winter, being similar to that of Southern California, only milder."

The peninsula is a narrow, mountainous strip about seven hundred and fifty miles long, from thirty to seventy miles wide. For the convenience of the sportsman it can be divided into three areas : one on the north abutting Southern California, two hundred miles long, is a continuation of the Sierra Madre, a fine range rising from five to ten thousand feet in air, on which one can stand and see the Pacific and the Gulf of California in one sweeping glance. These mountains abound in fine pine forests and form the source of numerous springs and small rivers, and in the lower region are some beautiful valleys where grazing and ranching are carried on. One of the most attractive is the Maneadero Valley, not far from Ensenada. Here one may see typical California ranches of the old days. Beyond this there is a central region, made up of table-lands and flat ridges, with mountains isolated and in groups, running up to four or five thousand feet. This extends for four hundred and fifty miles, which brings us to what Gabb calls the third province, extending one hundred miles from Cape St. Lucas to $\mathrm{La} \mathrm{Paz}$ and beyond 


\section{The Bighorn}

to the cape, characterised by great granite mountains from four to five thousand feet in height, with deep and often fertile valleys.

It is with the northern province that the sportsman has to do, and the splendid mountains, wild and majestic, that form the backbone of the peninsula here, afford some of the best bighorn shooting in America to-day, while in the lowlands are deer, antelope, and a variety of small game. All the ranges, seemingly culminating in the fine peak of San Pedro de Martyr, afford game of some kind.

The bighorn sheep may be considered one of the forms that is gradually growing scarcer and which ultimately will disappear. When I reached Southern California in 1885 , hunting it was considered one of the sports of the country, and I recall seeing two fine heads brought into Pasadena about 1887 , in which year several grizzlies were killed in the mountains. The bighorns were killed on the north slope of San Antonio, about fifty miles from the city of Los Angeles, where the remnant of the herd still lives, protected by the game laws of the State.

The animal is a splendid figure, with its enormous horns, corrugated, scarred, and turned back, bending down and pointing to the front again. It ranges from the mountains of Mexico north to Alaska, and is one of the splendid game animals of America that is doomed to pass over the divide sooner or later.

I was once on very good terms with a tame ram in Colorado, an old-timer having one in a small corral 
cheek by jowl with a mountain lion, and I spent much time in watching both. The result of my observation led me to believe that in a fair fight the ram would win, but if it were a case of sneaking up in the dark, or crawling over a cliff to drop on the game unawares, the mountain lion would be the winner. The bighorn certainly scented the lion, as it appeared to be in a constant "state of mind," which was evinced by occasionally backing off and striking the corral on the mountain lion side with a force suggestive of sudden death and the breaking in of ribs.

What a splendid animal he was, and what a coward was the mountain lion! Yet I may do the latter injustice, though he started as though he had been hit whenever the ram struck his partition and jarred the very earth.

A fine animal is the mountain sheep. He is wild and loves the wild places. His home is on the lofty, wind-swept crags of high mountains. As I write, I can look over the tops of palms and orange trees in my garden and see his home-the bare, pallid rocks that form the summit of San Antonio, two miles or more above the sea. The gentle wind in the valley of the San Gabriel is barely sufficient to arouse the music of the pine needles, yet up the north slope of San Antonio I can sometimes see a mass of snow rolling on, like a great white diaphanous cloud, that rises higher and higher, a wraith of the mountains, telling of the rigours of winter in this home of the mountain sheep. 


\section{The Bighorn}

There is something in the personality of the animal which attracts one, and I well remember the old cowman who owned the Colorado bighorn and who intended 'sending him to some zoölogical garden in Germany. "There's game for you, gentlemen," he said. "The big sheep is every inch an aristocrat; he may be a sheep, but he possesses the attributes of goat, antelope, and elk, so far as game is concerned."

The bighorn stands about three feet in height at the shoulders, and in his best condition weighs three hundred odd pounds, and he has a coat of various shades and tints. That of the San Antonio specimens I have seen, Ovis canadensis, was a very light brown and drab, a colour that so resembled the great cliffs and washes in which it was found that, when standing still, it appeared to melt and become a part of the basic slopes of its home.

The crowning glory of the animal is its horns, which are massive, deeply corrugated, flat, and ranging from thirty to fifty-two inches in length and from thirteen to eighteen inches in circumference. There is something about these massive head ornaments which stamps the mountain sheep as the aristocrat of his kind.

I have never hunted the sheep in Lower California but am informed by Mr. Grosvenor Wotkyns and Mr. Nordhoff, who has a ranch below Ensenada, that good sport can be found there in the upper regions of the southern Sierras, which are so accessible that the 


\section{Life in the Open}

localities most frequented by this splendid game can be reached on horseback, which is not often the case farther north. Once in this Lower California hunting ground, the sportsman will find himself on the very backbone of the continent, and at a glance can sweep the Pacific, the mountain ranges, the Gulf of California, and the vast desert beyond, and here, among scenes of chaos and desolation, is the home of the mountain sheep, that is sometimes followed from peak to peak, over countless divides, and into deep cañons before it is shot.

The sheep are so common that a hunt is rarely barren, and several good pairs of horns will repay the not difficult trip into this part of Mexico. 


\section{The Home \\ Mountain Lsion}

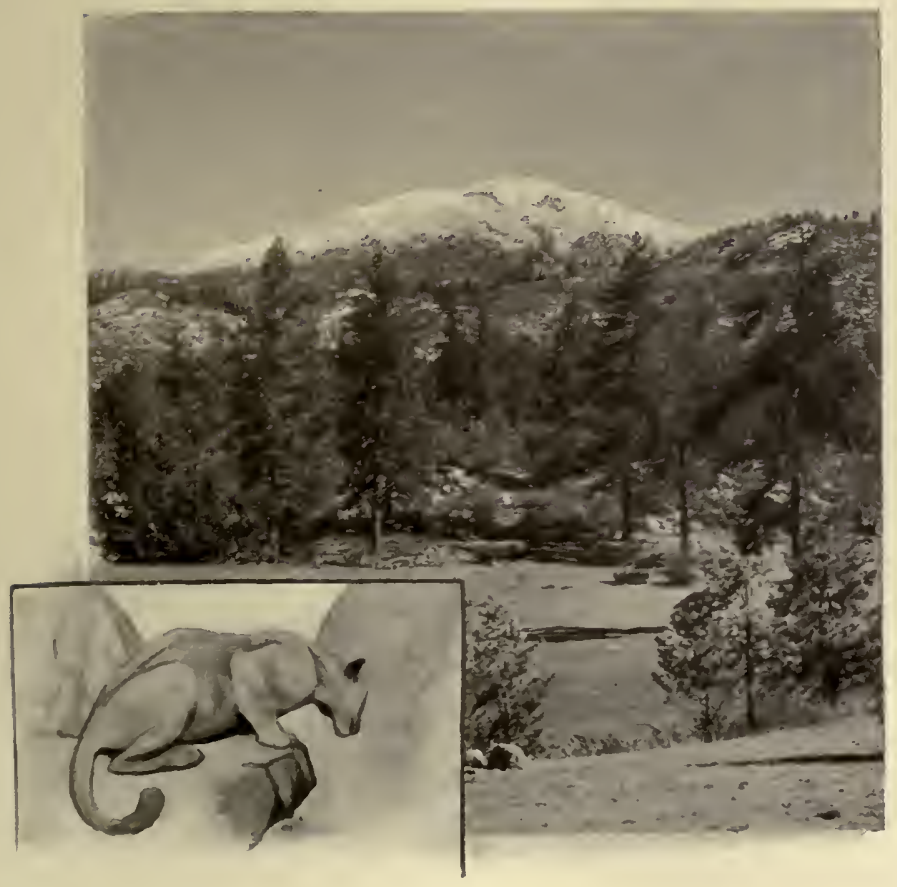





\section{Chapter X}

\section{The Home of the Mountain Lion}

AMPING out or living in the Sierra Madre in a rainy winter is not without charm and excitement. To look at the placid and wellwooded cañon that cuts off Las Cacitas from the mesa below in summer, one would never suspect the volume of water which often comes foaming down during the occasional winter rains. The river course is now dry; the summer sun has driven the water far below the surface, where it sweeps slowly along, the underground river that has given fame to Southern California. Yet I have been shut in by floods on this spur of the mountains for three days, and kept awake at night not by the roar of the waters, but by the deep, menacing sound of boulders rolling down the bed of the stream in a neighbouring cañon.

All these cañons, the arteries of the Sierra Madre, have not been made by a steady, regulated wear and tear, but by rushes of water, cloudbursts that suddenly wipe out the fixtures of years, carrying away whole 
mountain-sides, changing the face of the country, washing out more rocks and débris than the wear of five normal years would accomplish. The cañons are a feature of the country. The little stream foams down among the rocks and boulders capriciously. In the upper range there is a series of rocky basins, the water flowing from one to another over falls of deep green moss, while the face of the rock is covered with masses of maidenhair-ferns. Lower down, the stream flows over great boulders, leaping from one to the other, then out into long, pleasant reaches, to finally break away from the mountains and go swirling musically on to the sea.

In the cañon I have in mind I knew several men who preferred its solitudes. One day one came up to our camp, which was on a spur of the range, and said that a mountain lion had killed his burro and eaten part of it during the night, and he was afraid that it would return. A trip to the cañon camp, a rifle-shot away, showed the evidence of guilt : a small burro had been stricken down and torn and lacerated. Several hunters agreed to stay at the camp and see if the lion returned, but it did not, though its track was seen in various places, up and down the stream, testifying to its size. Not long after I was notified that a lion had been seen near the old Mission of San Gabriel, and one morning I joined the hounds in the shadow of the old pile and followed them over ten or fifteen miles of territory.

Some Mexicans reported that they had seen the 


\section{Home of the Mountain Lion}

lion creeping along at dusk. The next morning its tracks were found and the hounds readily picked them up near the old Mission tuna hedge, a mile to the east, but it was a forlorn hope. The country here was a mesa, without trees, overlooking a large vineyard some five feet lower, and every object could be seen for miles. The dogs took the trail and followed it down across country in the direction of Puente, where they lost it in the lowlands; and it was believed that the lion had made its way into the Puente Hills, crossing the entire San Gabriel Valley diagonally, so reaching the wild country about Mount Santiago.

In many of the mountain towns or those near the cañons, stories are current relating to the mountain lion, but the animal is rarely seen. One was killed near the Raymond Hotel in 1898 , and another was seen by a hunter on the old Mount Wilson trail, the animal slinking off into the chaparral. Doubtless a good pack of hounds taken up into the mountains near Barley Flats, or at the extreme head of the San Gabriel, would result in the finding of lions, but there are so few seen or heard of that hunting is rarely attempted. In the less frequented parts of the country, in the region back of the Santa Ynez, and between San Jacinto and the Mexican line, the deep cañons doubtless afford a home for many lions that are only occasionally heard of or seen.

The mountain lion is an interesting cat on account of its wide geographical range. My guide, years ago, entertained me with stories of the panthers he had seen 
in the Adirondacks, and I heard of the animal in Vermont hills near Lincoln as the catamount. In Florida the camp of a party of acquaintances was robbed by a cougar that took a pig, and though they watched all night the animal leaped into the pen and secured another pig, making off with the game amid a fusillade from the guns of a number of frightened negro servants. This cougar swam across a narrow channel to reach the key, or island. In South America, from Patagonia to Brazil, they will tell you of the puma and its ravages. I saw it first in the Rockies of Colorado, and the same animal appears on the coast from the far north, where it is known as the cougar, down to Southern California, where it is the mountain lion, and periodically appears, preying upon small animals, but mainly upon the deer, which in all regions appears to be the game of its choice.

In appearance the lion is a tawny cat bearing some resemblance to an Asiatic lioness, but much smaller : a typical cat, big, long of limb, muscular and beautiful. But here praise ends, as rarely will a mountain lion face a man, being by nature a cowardly animal, creeping upon its prey, and often intimidated by a single dog and hunter.

The big cat kills its game by stealing upon it,generally attempting, in the case of deer, to approach from above, hurling itself from an eminence upon the black-tailed or mule deer. In Arizona, California, New Mexico, and Montana doubtless many more deer are killed by mountain lions than by hunters. In some parts of Arizona 


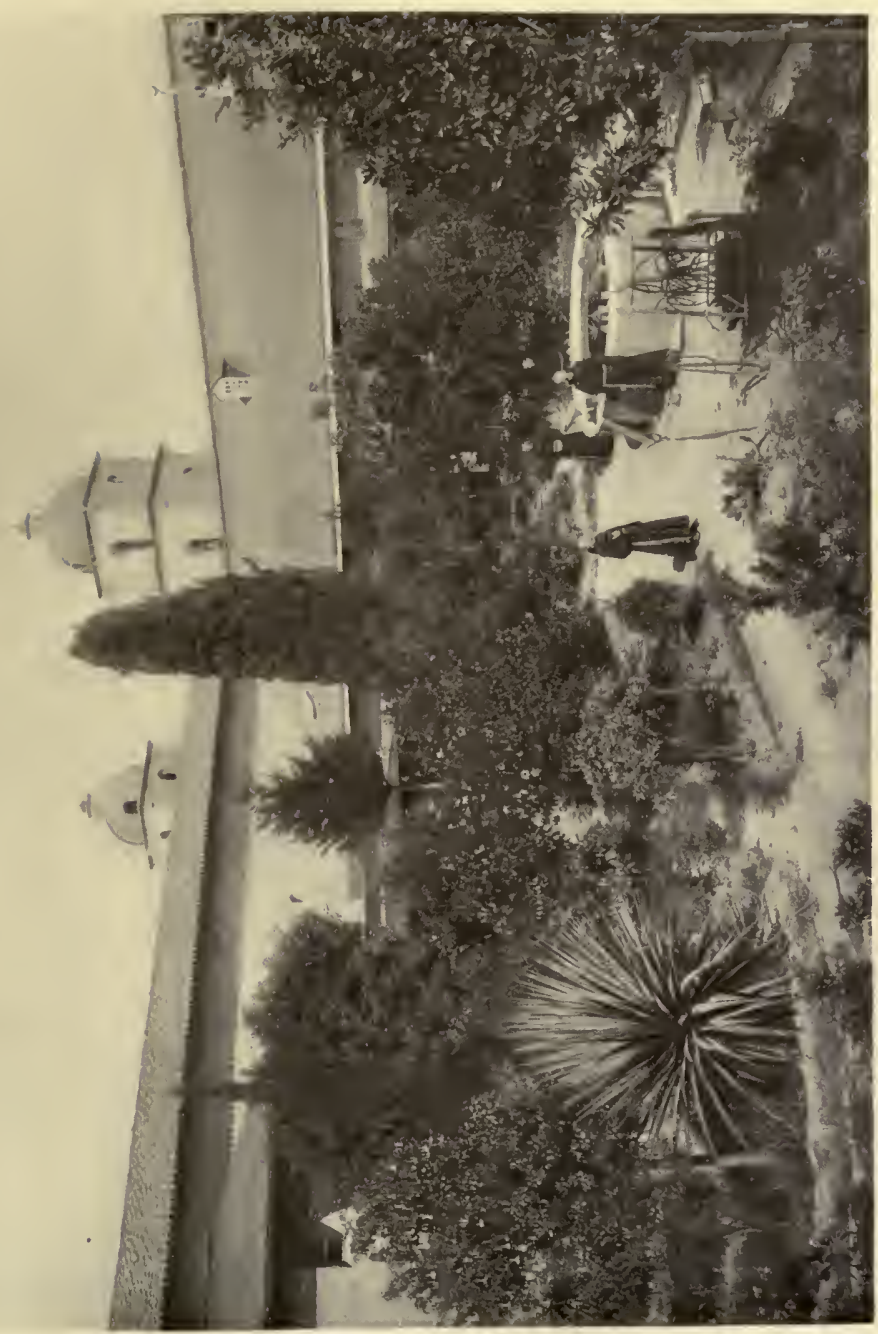

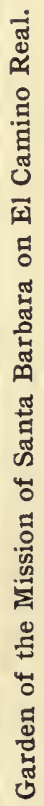



the mountain lions are so common, so much a menace to stock, that the cattlemen frequently combine and hunt them down with dogs. As a rule, the more difficult an animal is to take, the more eager hunters are to secure it, and I confess to many a ride up deep cañons and over narrow trails through the chaparral hoping to meet the lion of the mountain, and what I know of the mountains, their delights and pleasures, is mainly due to these quests for mountain lion and other game. I conceive, then, that the puma, call him what you will, is as good an excuse, perhaps better than any other, to induce the sport-loving reader to enter and know the Sierra Madre. $\mathrm{He}$ is there, but there is a more certain and definite game to be had : the impression and memory of mountain life, the personality and individuality of the mountains, that have peculiar charms and beauties of their own.

Mountain climbing is a sport, a pastime, a science, if you will, a science blending with the gentle arts and graces, as your real mountaineer is a poet; so I commend hunting the mountain lion in the Sierra Madre. No more fascinating hunting-ground can be found in the south than the great range, from the head of the Santa Ynez to San Jacinto. In this restricted area are some of the most interesting peaks in America.

These mountains face the Colorado desert on the east, one of the most desolate places on earth, at times a furnace: the hot air pouring upward in such volume that it leaves a pseudo vacuum, to fill which, the air rushes in from the ocean, explaining the 
steady breeze which continues in Southern California all summer. Mount San Jacinto has fine forests and streams and long, level stretches abounding in pines; regions that are covered with snow in winter and are gardens in summer. Here are numerous camps, reached by good trails and waggon roads-inviting to the lover of sport and camp life. The altitude is from five thousand to seven, eight, or even ten thousand feet, and the facilitiess are excellent. In the range opposite Los Angeles there are many good trails into the mountains. The Arroyo Seco is particularly available, a deep, well-wooded cañon, which can be followed into the range for twenty or more miles. In the cañon is a fine running stream that has been restocked with trout, and which will soon be open to the public. In the San Gabriel Valley, cañons open at short intervals for miles, many being famous for their beauty. Near Pasadena are the Arroyo Seco, Milliard, Las Flores, Eaton, and San Gabriel cañons.

The Mount Lowe elevated road takes one into the upper range to Alpine Tavern. Not far away, at Eaton's Cañon, is the beginning of the Mount Wilson trail, which, by an easy grade, takes the mountaineer up to Mount Wilson, where Martin's camp is stationed in a saddle just below the solar observatory of the Carnegie Institute, under charge of Professor George E. Hale. The pagoda-like observatory looks down into a deep cañon, a gulch of profound depths, the cañon of the San Gabriel River, one of the largest in the 


\section{Home of the Mountain Lion}

range. On the rushing trout stream are several camps, as Follow's, where lovers of mountain life and scenery make their home; and all along this stream private camps are found, outfitting in the towns of the vicinity or in Los Angeles, where there are houses which make a business of equipping hunting camps, providing everything but the game. The heart of the San Jacinto range is reached from Los Angeles on the Sante Fé road to Hemet, from which a stage takes one up the mountain trail, a mile above the sea, to Idlewild, where hotel, cottage, tent, or spreading tree can be had, trained mountain horses, and one of the most attractive regions to use as a base when mountaineering in Southern California, in what is virtually the heart of the California alps.

No more interesting mountain road can be found in California than the one from Hemet to Idlewild, or to the upper reaches of Mount San Jacinto, two miles above the Pacific. To reach this point, the top of the world seemingly, one passes by mysterious Mount Tauquiz, about which the old Indians say strange cries and groans are heard at times, weird tremblings which make the entire mountain shake. Here we find the Tauquiz meadows with running streams eight thousand feet above the sea; and at every rise new charms of scenery appear. The trip to the summit from Idlewild is about thirty miles over a good trail, and from here hundreds of square miles of California can be seen. The changes in forest flora alone repay the trip. From willow, sycamore, 
oak in the lowlands, the mountain-climber comes to spruce, firs, pine, and cedar. Farther on these become scarce and far apart, and near the rocky peak the trees creep along the ground, dwarfed, stunted, as though beaten down by a constant and relentless enemy. What the condition is here in winter one can imagine by watching San Antonio, seeing the dense snow clouds, hundreds of feet high, roll up its slope, rising above it like the white vapours of a volcano.

The mountain lover will find a delightful region about Seven Oaks, the head waters of the Santa Ana River, the point of departure being the city of Redlands from which a twelve-mile stage ride carries one to the half-way house. From here horses and guide are taken and the ride made up into the valley of the Santa Ana, famed for its trout streams and scenery, almost a mile above the sea. The country is well wooded with pine trees, and in the vicinity are Bear Valley and its well stocked lake, Barton Flats, South Fork, Cienega Seco, and other places of more or less interest.

The San Bernardino range affords many cañons and mountain retreats attractive to the mountaineer and sportsman, among which is Skyland above San Bernardino, five thousand feet above the sea. This country is reached by a good trail or mountain road, once the old Arrowhead toll road from San Bernardino. Here are many cañons-Devil, Sandpit, and Dark cañons,Squirrel Inn and Little Bear Valley, and reaching away in 


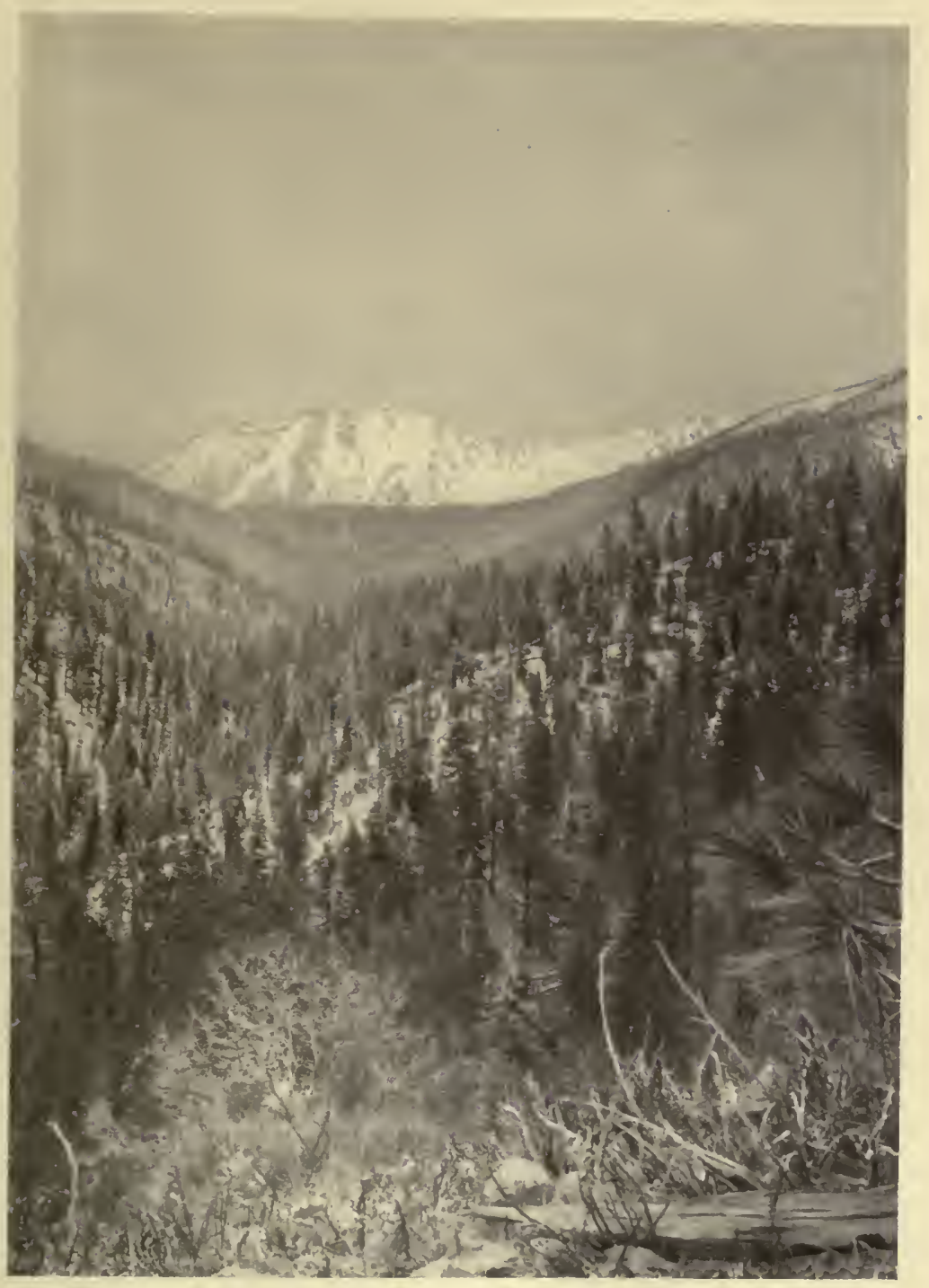

Haunts of the Mountain Lion, and Grizzly Peak (I I,725 feet high). 

many directions a richly wooded country that will tempt the mountain lover on into other delightful regions. All these places, particularly Fredalba, have summer camps and the amateur mountaineer can climb the range with ease, and have the comforts of civilisation; but recognising mountain climbing as a gentle pastime, I have in mind the lover of nature who would steal away from the roar of great cities and seek the solitude of the great silences of these mountains. I recall a friend who prefers to be alone in the mountains, who can be met in out-of-the-way places, generally unarmed, with a pack burro and simple outfit; sleeping where the fancy takes him beneath the trees. Others ride to the great upland mesas on the mountains in their own carriages or on horses, carrying the outfit. The mountains of Southern California are not often inviting to observers in the valleys; their south slopes have often been burnt over, are bare, rocky, forbidding; but the keen-eyed mountain lover will see a fringe of trees on the lofty divides that are mighty trunks. He will note the deep, blue cañons, and once in their portals and over the divide on the north and on well-wooded slopes, he will have discovered the charm of Southern California woodlands. Once the lower country was well wooded; the valleys abounded in oak forests; but vandal hands have cut them down, and the eucalyptus and other trees that grow rapidly have been planted by the new-comers.

In the cañons we shall find tall and picturesque syca- 
mores out of leaf hardly six weeks in the year; cottonwoods, willows, and the alder. A black and white live oak makes splendid shade in the bottoms where there is water; and down in San Diego County, in a restricted area near Delmar, grows the rarest tree in the world-Torrey's pine, a dwarf species not over forty feet in height. As we ascend the slopes the chaparral becomes a factor; a dense growth often covering the hills, the home of the mountain lion, deer, and mountain quail. It is made up of several kinds of brush, attaining the dignity of trees. This and two species of live-oak bushes and the Adenostoma or greasewood constitute the backbone of this foothill verdure. Then comes the Heteromeles, with its masses of red berries, the "holly" of the Southern California Christmas festival; the wild lilacs, with lavender and white clusters of flowers. Then the manzanita that here is rarely found on the lower slopes, though in the north I have seen it on sea level. This and the madrona, with several others, make up the forest of the approach to the Sierra Madre, a mimic forest ten or fifteen feet high, through which run quail, wildcat, and other game; a dense interlaced mass often almost impassable for man or horse. One of the most serious predicaments in which I ever found myself in California was when trying to make a short cut and ride down through the chaparral on a steep slope of this range.

Following up the cañons there is a succession of trees and shrubs. The little cañons and valleys are 


\section{Home of the Mountain Lion}

filled with ferns and brakes, alone a magnet to attract one again and again. The common brake is the most conspicuous form, everywhere rearing its graceful shape, and in damp places we find the bladder, shield, and chain ferns, cliff brake, the coffee fern beneath some scrub oak, and mimic plantations of maiden-hair, the lace and cotton ferns; and clinging close to the ground the showy gold and silver back varieties. Here will be a clump of the huge mountain tiger-lily, six, eight, yes ten feet in height, a splendid panicle of flowers, an orange patch against the background of green. The bay is common at an altitude of two thousand feet, a beautiful tree pouring forth an invigorating aroma when touched. Down the sides of the cañon roll acorns two inches long, in enormous cups, started by the gray mountain squirrel with foxlike tail, that eyes you from the dwarf oak on the slopes, and as you climb up the sides a flock of dark blue mountain pigeons take flight or the long-plumed mountain quail steals away. On every hand are evidences of the war of ages. Great slides of rock pour down like rivers and are, indeed, subtle slow-moving rivers of stone. Here the half of a mountain spur has dropped into the cañon, leaving a red and jagged wound. Part of the talus has been swept away by the winter's flood; part is covered by clustering ferns, while the young lilac and tall purple larkspurs tried to cover it with a mantle of colours.

Climbing higher the chaparral grows thinner, and 
hundreds of acres of titanic rocks stand bare facing the sun, with here and there trees fighting for life in the crevices. Higher yet comes the summit, 5000 or 6000 or 7000 feet above the sea. From Mount Wilson, which forms one side of the San Gabriel Cañon, one may, on a clear day, look on all the lofty peaks of Southern California. Yonder is Grizzly Peak, in the San Bernardino range, II,725 feet high; nearer, Gleason's, 6493; Cucamonga, 8529; Mount Conejo, $33 \mathrm{II}$; Argus, 6333; Brown's Peak, also in San Bernardino County, 5392. White with snow, and with snow clouds flying about its summit in winter, Mount San Antonio rises IO, I 20 feet into the empyrean, while Pilot Knob, far beyond, boasts of 5525 feet. Other sentinels to the east are Mount San Bernardino, 10, 100 feet high, San Gabriel Peak, 6232, and there are countless others, indeed Southern California is an alpine country by the sea; its valleys and level slopes are easier to enumerate than its ranges. The Southern California mountains have no Marathon to look down upon, but they have the sea, and from anywhere the blue Pacific with its outline of white surf gleams brightly in the sunlight.

Climbing up the mountains by the trails the scene is one of constant change. I have stood on the south flank of the Sierra Madre, four thousand feet above the Pacific, and looked down upon the San Gabriel Valley, one of the garden spots of the world. I saw its groves of orange, olive, and lemon, its palms and gardens stretching away for miles at my feet, resting in the green 


\section{Home of the Mountain Lion}

chaparral, yet in ten feet, by passing around a spur of the mountain, I reached the north side where the snow was a foot deep on the trail and every peak and slope was covered with snow as far as the eye could reach. Not only could one see winter and semi-tropic summer at a sweeping glance, but could leap from one to the other. This marvellous transformation is often seen lower down. On the upper slopes are found many pines, ponderosa, albicaulis, and monticola, false hemlock, white cedars, and juniper, up to five thousand feet the buckthorn, and beneath it the splendid wild fuchsia making or forming a forest garden in itself.

$\mathrm{Up}_{\mathrm{p}}$ to four thousand feet the great mass of the chaparral has been made up of Adenostoma, the "greasewood" of the Mexicans, and from the heights the eye sweeps over masses of this rich green vestment that rises and falls, dips into abysmal cañons, tumbling into the valleys like waves of the sea. We may pass through a narrow belt of madrona on the three-thousandfoot level, and now see the spreading, smooth, almost polished arms of the manzanita that reaches up to the greater heights; then, if on the higher mountains, come to forests and parks of pine, and then to the summits of bare and barren rock, crowned with snow in winter, and often bearing it far into the summer.

The highest mountain in the southern Sierras is Grizzly Peak, or Grayback, eleven thousand seven hundred and twenty-five feet, capping the San Bernardino section of the Sierra Madre, and remarkable as 
being the highest mountain in North America from its immediate base. Other peaks are measured from the sea level; but this stupendous shaft rises clear eleven thousand feet-over two miles-into the air from its immediate base, and affords one of the most profound and comprehensive views in the world. At a single sweep of the eye, the mountain-climber can face desert, ocean, and garden; almost every physical condition known to man is in sight. To the east lies the Colorado desert, its pallid yellow sands drifting into the distant haze. Here is the chasm of San Gorgonio, an abysmal gulf yawning nine thousand feet below. Beyond rises, sentinel-like, San Jacinto, with rocky flanks hiding groves of pine, beautiful glens and streams, a wonderland shooting upward ten thousand feet within five miles.

I have approached these mountains from the desert, where the stupendous masses of rock face a temperature menacing in its heat, and look down upon one of the most desolate scenes on the habitable globe. Nowhere is there a greater contrast than this heated wall of rock of San Jacinto looking down on Indio and Salton and the Salton sink, the bottom of an ancient sea two hundred and eighty feet below the level of the Gulf of California, and the region just over the divide that forms the splendid park region of San Jacinto Mountain, with its brooks, forests, and lakes. The most stolid mountain-climber is awed and silenced at the peaks, ranges, chasms, and gulches that stretch away before 


\section{Home of the Mountain Lion}

him. To the north lies the Mojave desert, to the south a maze of mountains, billows of eternal silence, rolling on into the distant haze to reappear far down in Mexico, rising in stupendous peaks, dividing the peninsula so that one can stand on its summit; on the eyrie of the mountain lion, and glance at the Pacific on one side, the Gulf of California and the mountains of Arizona on the other.

To the north-west, great ranges drop away to an altitude of five thousand feet, deeply wooded with pine, leaping downward like some living thing into the Cajon Pass to rise a green maze to Mount Cucamonga, tumbling away to the west, rising again in San Antonio to ten thousand feet, while far beyond are peaks which tell of the Sierra Nevada, taking one in imagination the entire length of this stupendous range that forms the backbone of California and stands a protecting barrier between the desert and the deep sea. 



\section{Valley ${ }_{\text {Quail }}^{\text {The }}$}

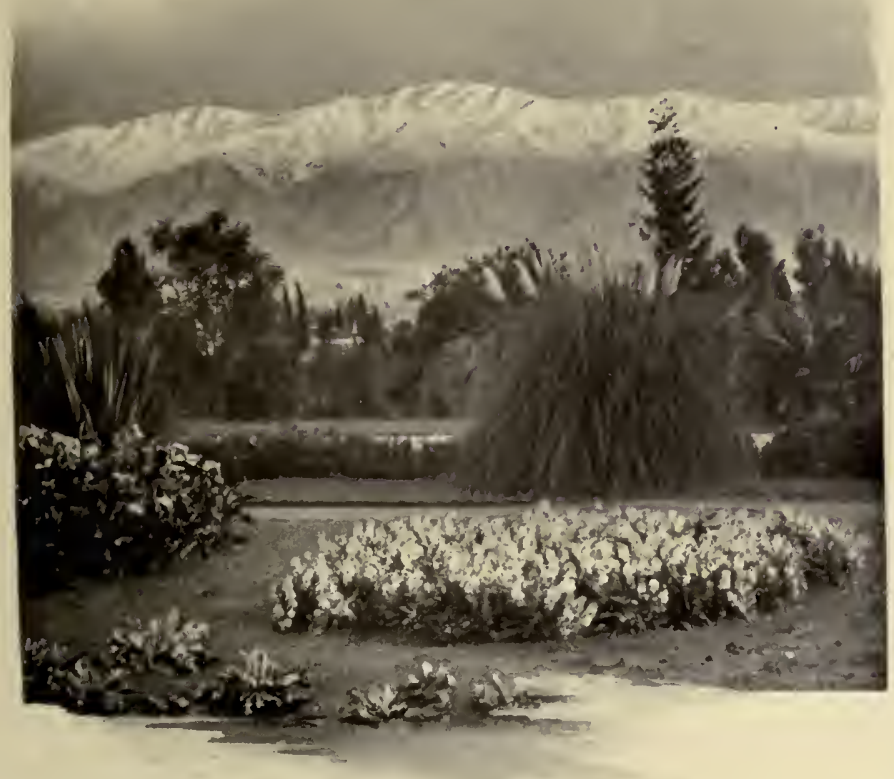





\section{Chapter XI}

\section{The Valley Quail}

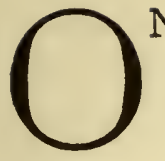

$\mathrm{NE}$ of the last quail hunts in which I participated led me over the San Rafael Hills, which rise to the west of the head of the San Gabriel Valley. Along the ridges I followed up the coyote trails to the summits, and looked down into a score of little valleys hoping to see a covey or hear the rich "po-ta-toe" rising from the green depths of the chaparral or see the birds in the open, but all to no purpose. As I wandered home in the cool evening I dropped over the edge of the Arroyo Seco, crossed it, and had climbed the opposite side, hardly a rifle shot from my home, when I walked into a large flock of quail; they were running across the dusty road into a field of dried burr clover, and, once there, stood and looked at me not fifty feet away, while I, returning from my quail hunt, also looked. This is what I saw-a flock of little birds, not quite so large as the bob-white, but each bearing jauntily a plume that fell over its bill to the front, giving the 
bird a most déconnaire appearance. In colour they were a mass of blue ash or slate, with striped chestnut hues below, with flashes of sun gold, white, black, and tan. The throat of the male was black, and he had a white "eyebrow" and a collar of white around his black throat, a radiant little creature, a pheasant in its colour scheme, and the incident of our meeting well illustrates the habit of the little bird. I did not fire; one cannot shoot down a neighbour in cold blood, if the laws do permit. Some of these birds nest in an adjacent garden, and I can often hear the melody of their notes in the Arroyo, or the thunder of their wings as they rise from the open and plunge down into the depths of the deep abyss. So, if one must have quail without compunctions of conscience, he goes away from home, out into the country in the unsettled districts where there is sport of the finest quality. When I first came to Southern California, plumed quail could be found every. where.' They lived in all the cañons and little valleys of the foothills, and held high revelry in the openings where the gravel of the wash spread out, fan-like, and merged into the low chaparral. Their flute-like notes could be heard at all times-whit-whit-whit-when you were near, and when far away the loud, screeching clarion challenge of the male-po-tā-töe, po-ta-toe, or ca-ca-cow. But the fencing up of the country, the growth of towns, has pushed the little birds out of back yards, and to obtain good sport the outlying country must be tried, where the dainty birds are found in vast 


\section{The Valley Quail}

numbers, and the vibrant whi-r-r-r-r-r-r-r-r often fills the air. No bird is so disconcerting. Recently, at Santa Catalina, in the off season, I was riding along when at a sudden turn my horse faced a covey of quail in the road. Did they rise? Not at all. The hens ran down the road a way, while the cock stood his ground, walking back and forth in a comical fashion, as though saying, "You know it is not the season and I am safe." These birds refused to fly and walked some distance down the road, then into the low bushes, where they watched me with many a notewhit-whit-whit.

Laguna and vicinity is one of the best quail grounds, and there are scores of localities all down the coast as good. You find the birds, perhaps, in some little valley shut in by hills, whose sides are covered with green Adenostoma and whose edges, perhaps, are broken with cactus patches. The air is clear, with a marvellous carrying capacity, and suddenly there comes woo-wha-ho, woo-wha-ho; and from another point or cañon rises o-hi-o, and many variants, possibly with a slightly different inflection. We are in the quail country, there can be no question as to that. They have not discovered you, and louder come the sweet notes, tuck-ca-cue, tuck-a-hoe, of the males, who are calling for the mere pleasure of it. Perhaps you are walking down the ridge and now look over; perhaps your gun has caught a sun gleam and tossed it into the next cañon; as up from the sage comes whit-whit-whit, 
the warning of the quail, and then perfect silence; then wook-wook, and from far away, wak-wha-who. You creep carefully over the divide to find them gone; indeed the flock is running off. The speed with which they make their way through the brush is marvellous; and by the time you reach them again they are ready to repeat the operation. After a big covey is met with, they will keep just out of range, and you gradually discover the secret, which is to throw Eastern diplomacy and strategy to the winds, and when a flock is sighted, walk, or even run, into it as fast as possible. The main body will rise ahead, but there are always three or four or more that stay behind and rise within range to afford you an excellent and often futile shot. In this way, hunting the flocks and advancing boldly and quickly upon them when found, a bag can be gotten in the easiest manner.

In point of fact, every ordinary rule is broken by the successful California quail hunter, and I well recall the amusement of a friend from the East when we were working up on a covey when I fired into the air over their heads. But he soon saw the philosophy of the movement. We were between them and the thick chaparral-covered hills, and they rose with a roar of wings and separated, going in all directions. And then our hunt began, as we moved on through the sage, the birds lying low and rising in the most unexpected fashion. One of my first experiences was in hunting over a descendant of the famous "Bang Bang." $\mathrm{He}$ 


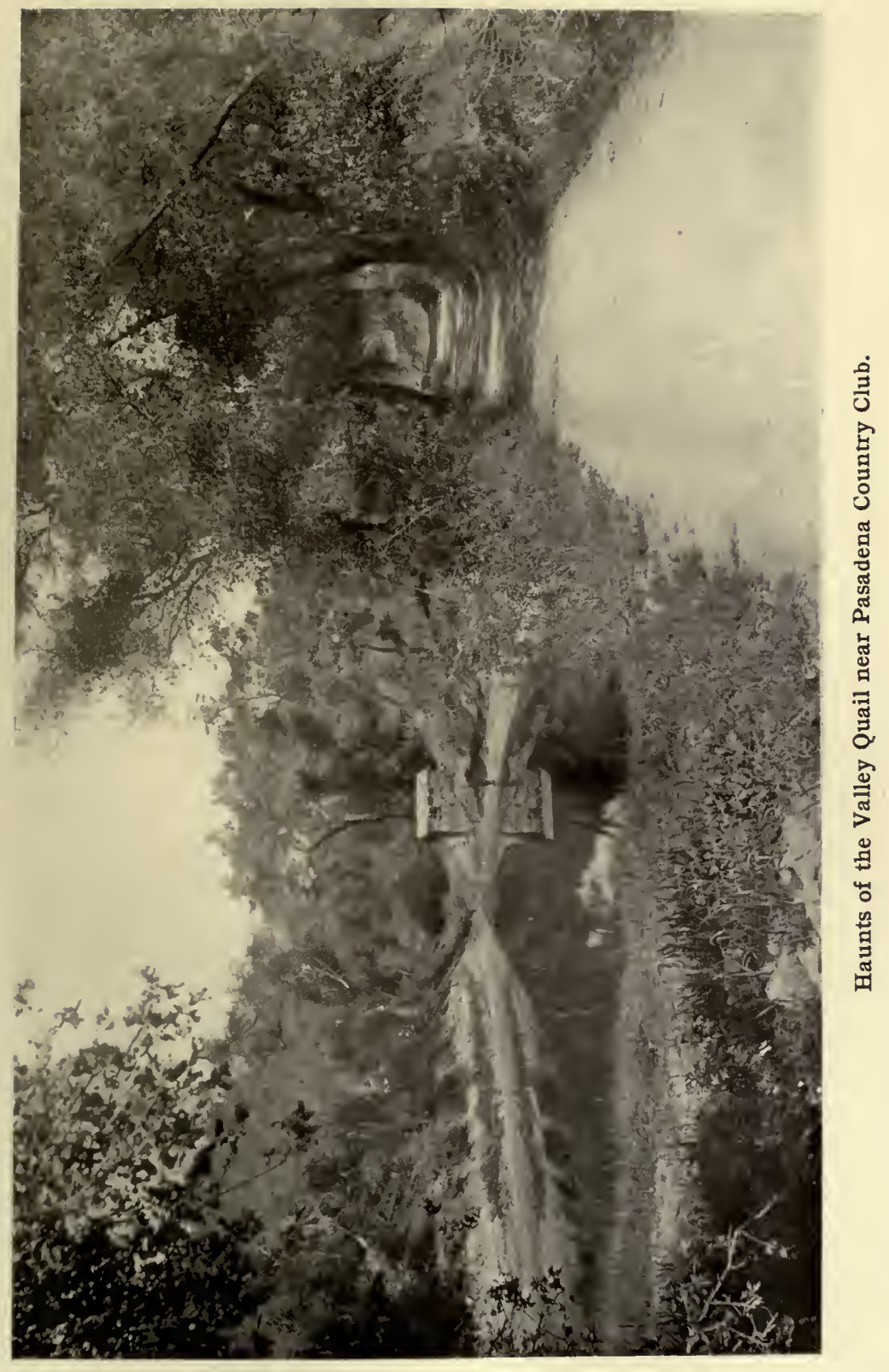





\section{The Valley Quail}

had never pointed a California quail, and the birds lay so close and long that he was fairly bewildered, but suddenly a quail rose almost under his nose, and came whizzing toward me, aimed for my head. I dodged, whirled about, and killed the quail exactly behind me almost out of range.

If the birds can be kept in the open in low brush, the sport conducted in this way is excellent, and the slopes of Laguna to the sea are an attractive place. Often the birds fly to the nearest hill, and you see them, with wings set, pitching over a divide and plunging into the chaparral like shots out of a rapid-firing gun. Then comes the whit-whit-whit, and if you were there you would see a few birds in the limbs watching you, while the others were walking upward with incredible speed, reaching the summit, perhaps, and leading the tyro a long and profitless climb.

Before the green has left the lowlands, and when the land is still running riot with flowers, early in April, the quail, or valley partridge, begins to nest, and the period extends far into the summer. The nest is often placed in an obscure place. It may be in your garden, or beneath a sage-brush, and I have found them in the Arroyo Seco, near water, hidden in a mass of vines, the bird darting out and trying every artifice to coax me away. From nine to twenty-three eggs have been found, but the average is from sixteen to seventeen. The young are able to run when a day or two old, and present an attractive sight, running in long lines. In a 
few days they fly, and later the valleys are filled with great flocks of grown and half-grown birds.

Quail hunting takes the sportsman into the open and affords him some of the most delightful glimpses of Southern California. If the San Gabriel fails there are countless valleys near Santa Barbara, in San Diego, Orange, Riverside, San Bernardino, and other counties which afford excellent shooting; or, one may go up the coast through Ventura or along shore above Santa Monica, or to Santa Catalina, where at the camp at Eagle's Nest, where the cañon dips down toward the sea, I have sat and watched the quail and listened to their continuous calls, kwok-kwoo-kwok-kwoo-or o-hi-o, $o-k i-0$, or $k a-l o i-o, k a-w a k-u p$, a medley of flute-like sounds and their variants coming from the high green slope of the mountains.

In February, when the charm of winter is at its height, the land is often ablaze with colour, and the sportsman may walk through little valleys carpeted with a cloth of gold, when the yellow and white daisy-like blossoms star the ground, and the yellow violet nods in the gentle wind, or he may emerge into a little valley where the painter's brush has drawn its colour scheme as far as the eye can see, while the low trees are covered with the brilliant red of the honeysuckle. Led on and on, he finds the golden mustard and later the indigo of the larkspur blending in the sun, and on the edge of the little wash trumpet-like flowers, a flame of colour.

In the wash, across which the birds now run, the 


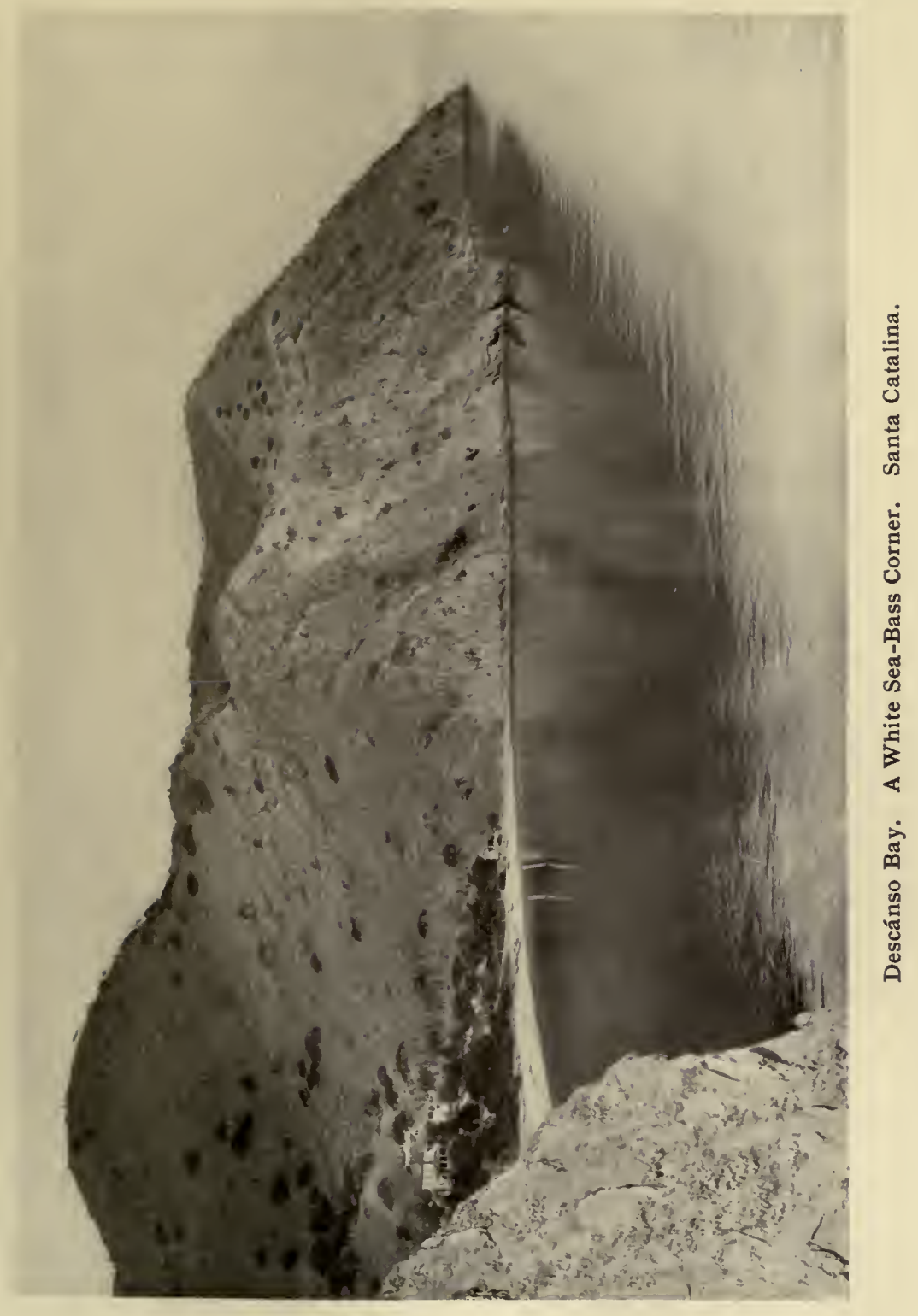





\section{The Valley Quail}

chilocothe hangs in rich green garlands and the little mounds are overrun with chlorizanthe, every portion of this winter garden having its charm, its scheme of colour and beauty. It is difficult to find the objectionable features which are a part of the hunter's or camper's life in other parts of the world, though I have heard critics denounce the sunshine as too monotonous, to which covert attack there is perhaps no reply.

I am free to confess that I have never shot a mountain quail, as I always feel that I never could find a satisfying excuse for destroying so beautiful a creature.

I first saw them on the north slope of a peak about ten miles back of Mount Wilson, in the, very heart of the Sierra Madre. I was lying under the thick branches of a wild lilac, resting after a hard climb, when through a leafy arcade, not one hundred feet away, came five or six mountain quail. I had just left a branch of the stream, and all about were brakes, giant ferns, and forests of the more delicate kinds, with here and there the tall stalk of the mountain tiger lily. A tree that had been thrown over in the long ago and covered with lichens lay half buried in the dense underbrush, and down this highway came the jaunty band, stopping every now and then, and uttering a peculiarly musical note that sounded like $c l o, c l o, c l, c l, c l$; then coming on until they reached a point hardly thirty feet from me, when they again stopped and eyed me with idle curiosity, then came ten feet nearer. A more dainty creature with its long plumes it would be difficult to imagine. 
A striking feature is the chestnut-hued throat, black banded, surrounded in turn with a pure white band and on the sides pronounced bars of black, chestnut and white.

I did not move, and they came on until within six feet of me, gazing with their gentle brown eyes, looking me over, examining my gun, and evidently deciding that I was some kind of a sportsman, but harmless. As they paused, I uttered a low whistle and they turned, each lifting its head, as though to catch the sound, and then like magic they melted away. If any one has the fancy for the hardest kind of hunting, in the hardest kind of country, I can commend this, as the birds while often seen in the foothills are found principally in the thickest chaparral of the upper ranges, and to follow them requires, at least did when I knew them, the most difficult climbing.

The nest of this quail has been found hardly a mile from my home, four miles from the base of the Sierra Madre; but the nests are not easy to find and are mostly in the heart of the great range where nature has afforded them ample protection.

There is still another quail in Southern California, the quail of the desert, or Gambel's partridge, found principally in Arizona, but also on the borders of the desert where it merges into the high mountains of California. In many ways the bird resembles the valley quail, and its habits are similar, though it has the desert habit and seems to love the regions that man avoids, the 


\section{The Valley Quail}

great washes where the heat is often like a furnace blast. All these birds are easily tamed, and within a short distance of my house an acquaintance has all three varieties in confinement. 



\section{The Theart $_{\text {of }}$ the
Desert}

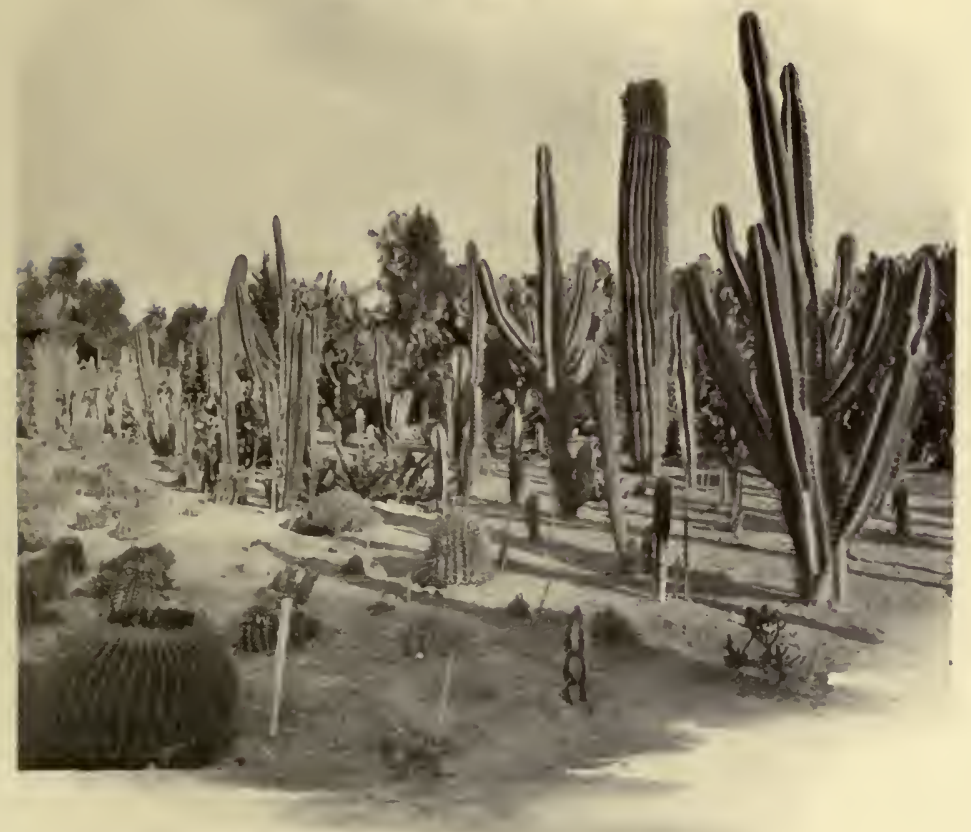





\section{Chapter XII}

\section{The Heart of the Desert}

\section{The Pronghorn}

$\mathrm{T}$ is among the strange anomalies of life that some men see a charm in regions that others describe 1 as God-forgotten; localities where Nature is at her worst, where the elements are abroad, searching for life, falling upon every living thing. I have crossed the great American deserts many times; have seen them in all their moods, have driven over parts of them when the limit of heat endurance was seemingly reached, and never found any one who cared to live there; yet it is rare to find one who fails to recognise the peculiar attraction of these sand wastes, the home of the mirage and sand-storm. I recall the sunset illumination of the Sangre de Cristo Mountains, which rise in what some might call a desert, yet far from it, and have since observed the same effect in the Sierra Madre from the desert to the east of Mojave. No more forbidding vista ever filled human vision than parts of this desert, consti- 
tuting the eastern portion of California. A curse seems to have fallen upon the very vegetation, which is weird and fantastic, befitting the surroundings. At mid-day the full force of the sun beats down upon rock and sand, the buttes assume a thousand shapes and to the eye are isolated castles which imagination garbs with romance and mystery. The vision is distorted, a wavy, nebulous mist rising from the ground, changing the form, colour, and appearance of all objects. The shadows have been driven from the land, and the glare of the sun is like the blast of a furnace, if in summer; yet the traveller can but recognise the strange beauty of the region, as nowhere can such pure colour or its complete absence be seen. There is apparently no life where the white sand sweeps on, but the drifting dunes have a weird life of their own and are ever moving, changing like some restless monster, and in the region of the Salton, reaching up to the Sierra Madre, present the appearance of a vast river flowing on eternally; even when the wind is in abeyance the sand is moving. All over its surface are small currents rippling on, cutting furrows, carving figures of strange design, the caprice of the wind.

The scene when the wind, developed into a sandstorm, sweeps down this vast pass, or el Cajon, is beyond description. The very earth appears to be lifted into the air and carried on, a wall of copper-coloured cloud. With even a full knowledge of this region it is difficult to select one portion which has not at times some feature that appeals to the imagination, yet is calculated to alarm the 


\section{The Heart of the Desert}

physical man; but, in my experience, possibly the strange valley which reaches north from Cochise in the territory is the most remarkable. Little wonder the ancient people had legends of giants and possible genii, as no desert region in America presents so weird an appearance. To the south the eye rests upon a vast lake, which can be seen ten or twelve miles distant from the slopes of the mountains, and when I first saw it, its beauty was entrancing. Away to the south, on its borders, were hills of purple, each reflected as clearly as though photographed, and still beyond rose the caps and summits of other peaks and mountains rising from this inland sea, whose waters were of turquoise; yet, as we moved down the slope, the lake was always stealing on before. It was of the things dreams are made of, that has driven men mad and to despair, its bed a level floor of alkali and clay, covered with a dry, impalpable dust that the slightest wind tossed and whirled in air. No more beautiful mirage can be seen in this country if one cares to visit the region in August. As I watched this lake of the imagination, I saw the rise of the genii of Cochise from its mirror-like surface. Like the giant of Sindbad, from the flask of the fisherman, they rose upward in weird and colossal shapes, then moved slowly off over the surface to the south. On my last visit to this valley in midsummer of 1903 , this marvellous scene was at its best, and from fifty to one hundred sand or dust-spouts or columns could be seen sweeping down this valley of 
horrors on to the lake of literal despair; some so high that they appeared to support the very empyrean, and so exact in their imitation of water-spouts that it was impossible to disassociate them from the sham water on the illusive lake.

Once while crossing this valley-which despite its menacing character is to be a desert reclaimed and a railroad point of importance in the future,-innumerable sand-spouts appeared to join forces, forming a gigantic column seemingly a mile in height. It was of a lurid, copper tint, menacing in shape and colour, sweeping along with the stride of the wind, its upper portion whirling about as though in a vortex.

Despite the disagreeable features of these desert phenomena, their beauties, the grandeur of the effects, more than repay one. What can be more beautiful than the view from the desert near Palm Springs? As night draws on, the tops of the mountains are tipped with the most brilliant vermilion, which grows deeper and more firelike as day shortens, and all the time, out from the countless cañons, cuts, and passes, creep deep shadows, like living things, venturing out as the sun loses its power. At first they flood the cañons, then flow down, spreading out in ineffable tints, stealing out upon the sands of the desert into its very heart until they fairly fill it, and the great waste is a purple sea, awash with the panoply of night. At sunrise this strange transformation scene is reversed. The tips of the range are again bathed in vermilion and the shadows slink away, 


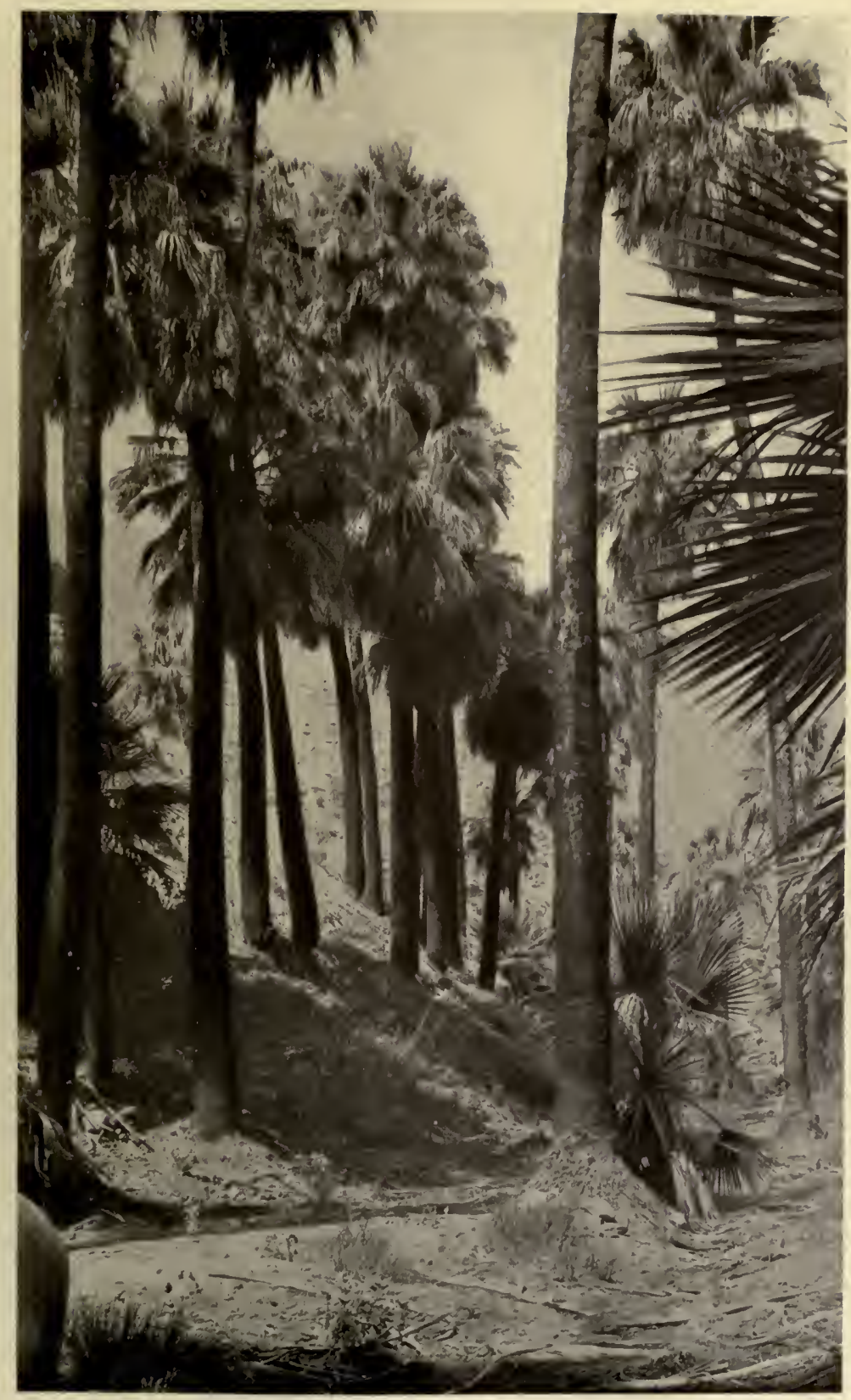

A Desert Forest. Native Palms near Palm Springs, California. 



\section{The Heart of the Desert}

retreating to the cañons, seemingly utterly driven out by the fierce rays of the sun.

No one can deny the charm of such a region, and the impulse to move on and into the heart of the desert is often almost irresistible, the strange buttes ever beckoning on. The vegetation of the desert, while forbidding, has its attractions. What might be considered the very heart of the desert, as the alkali plain between Yuma and the Sierra Madre, is apparently divested of vegetation, but careful examination shows something growing in the gullies, and even where the sand is tossed like snow, a grass appears fighting for supremacy, while a few bushes struggle upward. On the edge of the desert, in cañons which at times reflect the summer heat like a furnace and through which the superheated air rushes, are seen lofty palms, their roots deep in the rocky channel that the winter rains have made. In some of the cañons the palms grow in great numbers. Apparently the seeds are swept down on to the lower levels, and where the cañon opens out and becomes a wide valley groves of lofty palms are seen,- - among the most picturesque and beautiful forms of the desert.

It is doubtful if one can make a strong enough plea for the desert to induce people to visit it. Thousands cross its very heart every year to reach Southern California; indeed one cannot reach the Pacific by land except by the desert route; but the average tourist fails to see it, as the railroad has so arranged that the passage of this dry Styx is made by night; thus its varied 
attractions are lost. It may savour of exaggeration to some readers if I say that I have felt vastly more uncomfortable in Chicago, New York, or Philadelphia than I have when passing through the heart of the desert in midsummer. Not long ago I made the trip across what is considered the hottest part of the United States in the hottest time-or August,-crossing the California desert to Yuma, then on through Arizona and New Mexico to Texas, and so on to the Gulf near the mouth of the Rio Grande. Doubtless to some the land for the entire distance was a desert, and certainly it was not far from it, so far as appearance was concerned; a dry hot ride of several thousand miles; yet I have been far more uncomfortable from heat in the East, north of Cape Cod. This unpopular region, in parts, is truly a desert, particularly the eastern portion of California, but it has its compensations; it appeals to the lover of nature, its. very barrenness in places giving it a peculiar interest. The great beds of shifting sand, where there seems to be absolutely no vegetable life, are fascinating to some. They have a life peculiarly their own. They move, they seem to breathe, they change form and stature from day to day; now rising high ; anon low and flat; now creeping along in many streams or rivers; towering high in air - a spectral cloud to sweep along, shutting out the entire desert from view.

Few places are more desolate than the slope of the Sierra Madre as it rolls down into the Mojave country ; yet I have always been rewarded by the splendours of the 


\section{The Heart of the Desert}

sunset on the Sierras from this portion of the desert. Leaving the hills, we enter a forest of yucca, the weird distorted branches, seemingly stricken by the blast of death, reaching out at one; a forest of fearsome shape and feature that occupies a belt four or five miles wide, then melting into the sands of the desert with distant buttes on the line over the edge of the world; cities, temples, towers, minarets of the fancy, that lure one on and on.

But turn to the Sierra Madre at sundown and teil me whether the desert has called you in vain. Watch the purple shadows creep out of distant cañons and encompass the pallid desert. See the banners of encarnadine painting each cliff and peak until the entire range is suffused with a warm glow, as though some roseate lace-like film had been drawn over them as they sank into the deep gloom of the night.

But what have the deserts to do with sport ?-you will ask. I might reply that the study of the desert affords infinite pastime. Come down through the forest of yucca, where the mountains sink away to the sagebrush, when the winter has come, when the sky is clear, and the rain has washed from the air every scintillating atom; come into the shadow of this clump of desert brush on the edge of a wash. Your eye may see nothing in this vague landscape, this blaze of colour and tint, that Lungren knows and paints so well; but if your luck is with you and is of a specious quality, suddenly something moves far away in the centre of the 
valley. It might be a phantasm, the outline of a tall yucca; but out it comes, and resolves itself into a bit of the desert landscape, two, three, four pronghorns, the last of the Californians to hold their own in Antelope Valley, the rarest of California animals, with the great condor and grizzly, not to be hunted with rifle, but to be looked at and bidden godspeed and long life if you please. I conceive various kinds of hunting: there is hunting with the eye, watching the beauties of game, and its ways; and that it has its advantages is shown by the fact that you may repeat it indefinitely, and the more you hunt in this way, the better grows the sport, the more plentiful the game; and I bespeak for the little California antelope the hunter of this class, that his life may be long in the land that once knew him so well.

Not many years ago the pronghorn was among the commonest animals in the open country. Large herds lived in the vicinity of Elizabeth Lake, and the great valley that extends from the Mojave desert west, or north-west, was named for them. In those days they could also be found in the Mojave and along the mountains of California everywhere. They appeared to rise from the bed of the pallid silent sea of sand. But, like the buffalo, the antelope has been crowded to the wall in California, and a few small herds only haunt the great desert of to-day.

In his antelope range map of 1902 , Merriam recognises a few in the extreme north-west of California, and another herd near the Mexican line where Imperial and 


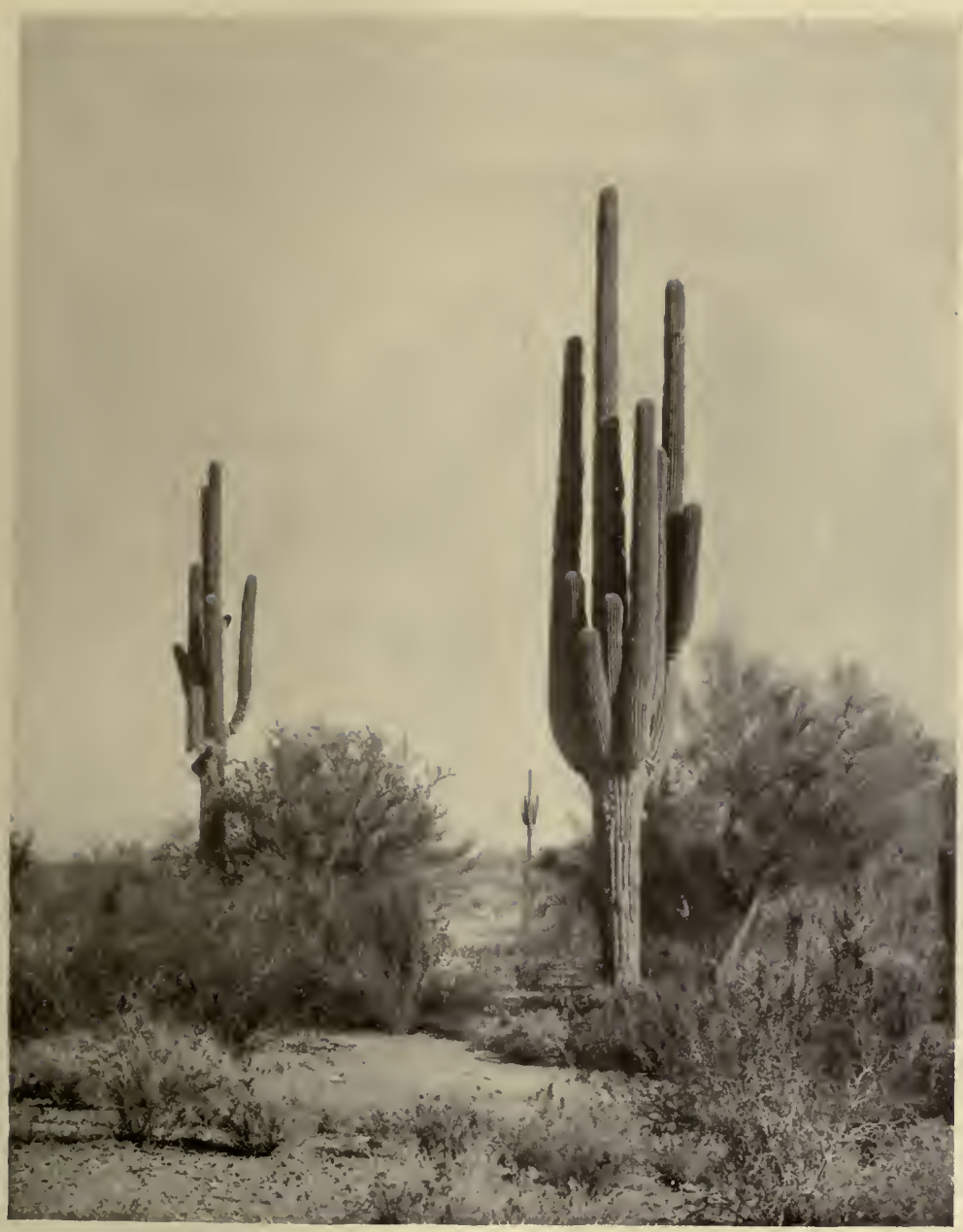

Candle Cactus, Lower California and Arizona. 



\section{The Heart of the Desert}

other towns now stand, or in the country west of the delta along New River. If one wishes antelope hunting he must go to Arizona, Sonora, Chihuahua, Montana, or Wyoming; or, nearer, take the steamer for Ensenada and hunt for the only American antelope in Lower California, in whose ranges the mountain sheep is also found.

Within fifteen years there has been excellent antelope hunting in the Mojave and Antelope valleys, which shows how suddenly this game has been driven out by the march of enterprise. On the Mojave desert I met an old Californian who told me that he had had the sport of his life before he got so "long in the tooth." His method was to follow the antelope on horseback; either run it down, or shoot it from the saddle at full speeda dangerous and sportsmanlike method in strong contrast to the fashion of some hunters who entice the little creature up to them by "ways that are dark" and shoot it down, a victim to curiosity.

The pronghorn is one of the most interesting of all American animals, and should be shot only with a camera. It is the only hollow-horned animal that sheds its horn sheaths-a feature that was long denied or doubted, and believed impossible. In the early days it roamed over the great plains and was essentially an animal of the open. Its hair is rough and stiff, its horns graceful, with a single prong half-way up, and near their base the large and prominent eyes which enable them to see an enemy for a long distance behind. In the 
north the herds migrate at different times of the year, but in the south, as in Mexico, they are found in the same general localities year after year. The young are born in May or June. For a few days they are helpless, and would be easily passed by as a stone or as brush, the little one stretching itself out, laying its head flat, and remaining perfectly quiet though a pack train passes within a few feet-unconscious mimicry that of ten saves it from enemies. By all means hunt the antelope on the California desert, and when it is found, let it pass. The compensation is a glance at one of the greatest deserts of the world, a vast dreamland, which some winters is a bed of flowers, and in summer is often a fiery furnace, a menace to life.

A fascinating part of the desert is that portion near Indio, where, in the present year, that spectre of this desert, the "Salton sea," rose and filled the Salton basin until the Indians, who took to the hills, could not see across. This strange phenomenon threatened various desert towns, and bridges were washed away. Boats were built in Imperial in this year when the Rio Colorado ran wild, broke through the intakes of the big irrigating canal, and found its way by old trails and new riverbeds to the Salton sink, two hundred and eighty feet beneath the level of the sea. The last time I rode into Indio the locusts were "stabbing the air with their shrill alarms," and one could smell the heat. It was too hot for originality, so I remarked to a native that it was hot, it being $110^{\circ}$ in the shade. He smiled and begged 
to differ with me: "It was cool; yesterday it was hot, $130^{\circ}$ in the shade."

In the vicinity of Indio one finds a palm forest, one of the things worth seeing; a forest of tall fan palms, which appear to be indigenous to the locality, reaching down into Lower California. They are found growing in the narrow heated cañons, their roots in the hot seeping water ; others out in the wash of the cañon's mouth - splendid examples of a desert forest which appeal to the imagination and the lover of the picturesque. Not long in the past this entire area has been under water; an old sea-beach may be traced a long distance from near Yuma to Indio, and a water line can be seen along the base of the mountains that form the barrier between the desert and the garden spot of Southern California.

Nearer the delta the land is being reclaimed, and ranches and farms laid out, and with the Midas-like touch of water the desert sands turn to gold; and where once sandy dunes drifted to and fro, vast fields of grain lie rippling in the sun, telling of the desert reclaimed and homes where some one may yet sing with Byron,

Oh! that the desert were my dwelling-place With one fair spirit for my ministerThat I might all forget the human race And, hating no one, love but only her. 


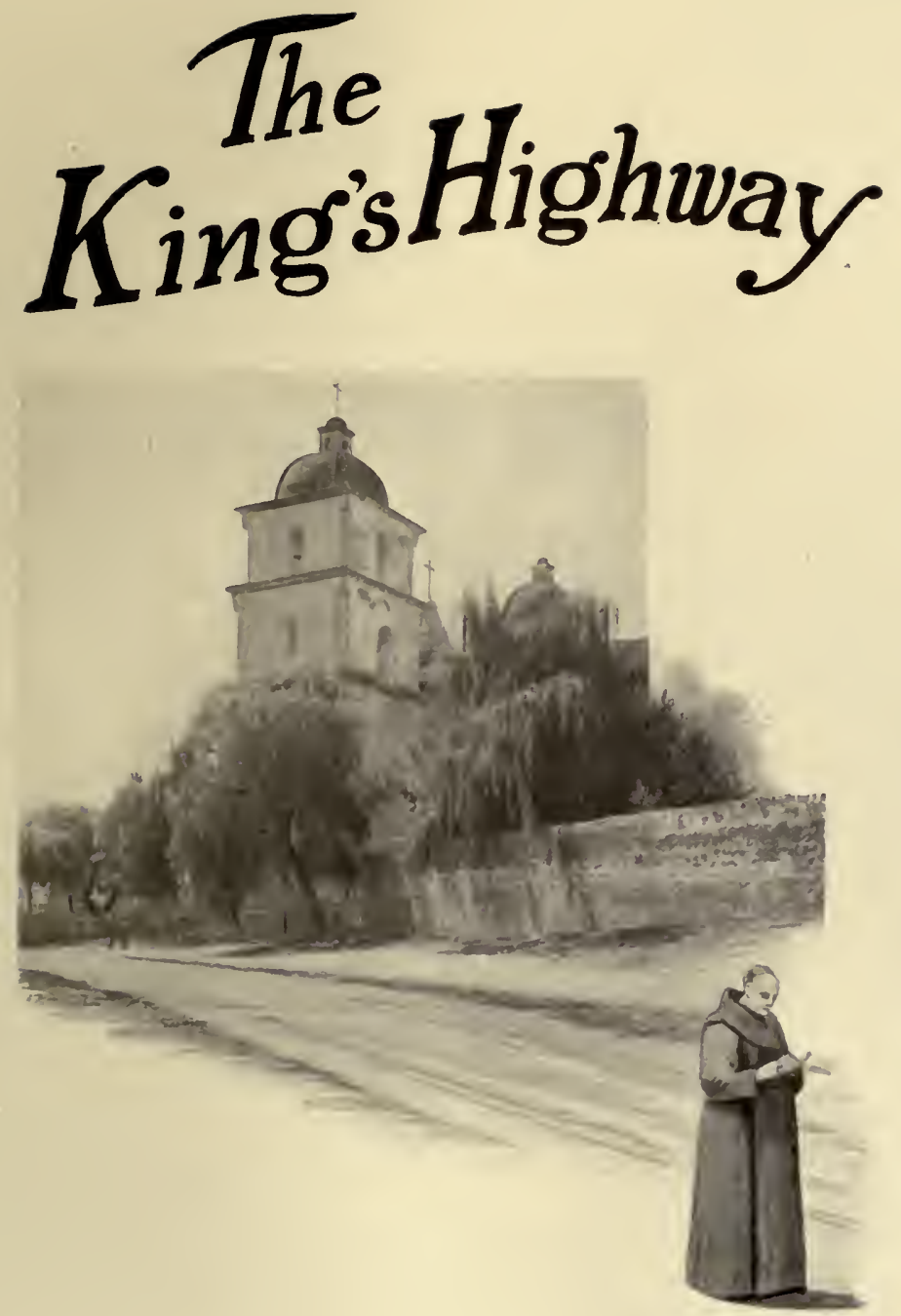



\section{Chapter XIII}

\section{El Camino Real}

\section{(Coaching or Automobiling)}

I OS ANGELES was the starting-point, the centre of radiation for many of our coaching and riding trips to Santa Barbara and beyond and through Southern California to the adobes of Tia Juana. To see Southern California effectively the trip should be made by coach, motor-car, carriage, or on horseback. Excellent roads extend all over the country, inviting one to the old ranches, cañons, ruins, and Missions which cannot be seen from car windows.

It was a mere conceit, perhaps, but remembering that in the olden time pilgrims and travellers in this fair country found a Mission at the end of nearly every day's journey from San Francisco to San Diego and be yond, along El Camino Real, the King's Highway, we determined to emulate the ancient custom and go over the old roads; not on horseback, as did the old Californian, but in a four-in-hand, making as nearly as possible a Mission every night, seeking the hospitality of its secularised walls in reverential fashion, as did the 
traveller of the last century, yet receiving it for obvious reasons, perchance, at the neighbouring inn.

The plan had not only an essence of romance and novelty to commend it, but was within the possibilities, the ecclesiastical chain being as follows, beginning at Santa Barbara:

Santa Barbara Mission, founded in 1786 , by coach to the Mission of San Buenaventura (1783). From San Buenaventura to Mission of San Fernando (I 797), then to the Mission of San Gabriel Archangel (177 I). From San Gabriel to San Juan Capistrano (I 776). From San Juan to the trio of Missions of Pala, Rincon, and Pauma. Pala to San Luis Rey de Francia (I798). San Luis Rey to the Mission of San Diego de Acala (I 769). Not only could these Missions be reached in a single day's journey, but inns or hotels were available. This with the guaranty of fair roads, good weather, and choice scenery made the trip one of more than pleasant anticipation.

The four-in-hand was not running on time; there were no relays to be met; hence the attempt to make a new Mission every night was not directly adhered to, though the ecclesiastical route was followed literally as outlined, with many an interesting side-trip to cañon, seashore, and mountain range. Under such inspiration a jolly party bowled toward the Santa Barbara Mission one morning, and reined up under its ancient walls. The "outfit" was a modernised California coach, the plethoric boot packed with hampers of good things; 


\section{El Camino Real}

rifles for the black-tailed deer, and shotguns for the valley quail, while four or five grey-and stag-hounds following were suggestive of hare and coyote as game.

According to a calendar which the young lady on the box seat carried, it was that thoroughly uncomfortable period midway the Christmas holidays and the first of March, when in the East thaws and violent freezes follow each other like avenging Nemeses; yet here nature seemed conspiring to impugn the testimony of the records. It was winter as the seasons go, but to all intents and purposes midsummer in Southern California. The cool breeze was coming in from the Pacific, sweeping up the mesa of the old town, bowling over acres of golden poppies, robbing the field of wild forget-me-nots of its perfume and carrying it over the Mission wall, to mingle with the floral incense of the old church garden. The driver called it a winter day; yet as he flecked his leaders and the horn gave an answering note to the meadow lark on the Mission wall, there was not one in the party who really believed that the Ides of March were near at hand.

From the highlands about the Mission the finest view of Santa Barbara is obtained. The Pacific is before us, stretching away to illimitable distance, the crescentshaped beach facing the south, from which reaches back the intervening town with its broad streets lined with palm, pepper, magnolia, and a wealth of semi-tropical plants and trees. To the north lies the Santa Ynez Valley, the blue ocean on one side, the mountains on 
the other, while to the south and east deep groves of orange, lemon, lime, and olive tell of E1 Montecito and Carpenteria.

It was at the Mission that the complete supremacy of man was demonstrated, as, after interviewing the courteous Fathers, the gentlemen of the party were invited into the Mission garden, while the ladies rested in the outer hall, consumed with curiosity. No woman -with one or two notable exceptions, as the Princess Louise-had ever entered the garden, so it was said; and the old gardener, gowned and cowled, laughingly told of the pretexts adopted by fair visitors, who evidently believed that the grim walls concealed some deep and unfathomable mystery.

The Mission of Santa Barbara is the only one that has never been out of Franciscan control, and is one of the finest in the State, standing as it did nearly a century ago when its bells rang the Angelus, their echoes calling the faithful up the deep cañons of the Santa Ynez.

The Father told us of the ancient splendours of the church, of its inception by Junipero Serra, its erection in 1786 by Father Antonio Paterna, and detailed its completion in 1794. In 1810-12, he said, it was almost shattered by earthquakes, but was ultimately rebuilt, then torn down and the present building founded in 1820 . We entered the old dormitories, the workshops once filled with native artisans, stood on the red-tiled roof, and looked down upon the broad, arched corridors where the Fathers walk and read; strolled among the 


\section{El Camino Real}

ancient graves of the founders, and tarried in the quaintly decorated chapel, while the Father whispered the history of the treasures upon the walls. He told us of the struggles of the Fathers; the acts of the Mexican Governor in 1827 , resulting in the destruction of the revenues of the Mission; of the desecration that accompanied the demand for secularisation, and various efforts at confiscation. In 1833 the government succeeded, and the Missions were converted into secular curacies. Later the Missions fell into the hands of commissioners, and in 1834 the public literally seized the Mission lands. We listened to the story of the successive phases of the struggle, of the times under Don Juan Alvarado, of the attempt in 1840 to restore the Missions to power, and of the act of Pope Gregory $\mathrm{XVI}$., in the same year, making California a bishopric, and many other moves resulting to-day in the Missions being, instead of centres of ecclesiastical power, more like simple parish churches.

This Mission as a whole is a delight to the artistic eye. The cell-like rooms, the ancient and worn stone pavements, the crude doors with huge iron trappings, the high windows, enormous walls, the odour of sanctity, all tend to complete a historical picture of deep interest. Without, the commanding front with its two towers of stone and adobe pierced with arched doors, the lofty façade with its finely cut columns, the timeworn statues of the saints above, make the pile at once striking and impressive. No little architectural and 
artistic skill was shown by the builders. Especially does the stone fountain in front, with its round basin and quaint carvings, attract the eye. Near here was an adobe bath-house, in the façade of which a lion's head was carved, from which once poured the clear water of the Santa Ynez. It is evident that the makers of the Mission were men of deep religious and artistic feeling; and the old building reflects credit upon their memory.

But we have tarried too long. A number of darkeyed penitents are waiting for the Father by the confessional, and after handing an ancient nail or spike of the old Mission as a memento to one lady, a photograph of the church and some flowers from the garden to others, the Father disappears to banish the past in the sins of the present generation.

Santa Barbara reminds one of some of the Mediterranean resorts, and has been compared to Nice; but the comparison is hardly just. The American resort has the advantage in climate, is always delightful, indeed perfect, winter or summer. Its winter mean is $54.29^{\circ}$, that of Nice $47.88^{\circ}$; its summer mean $67.7 \mathrm{I}^{\circ}$, that of Nice $72^{\circ}$; its difference between winter and summer $13^{\circ}$ to $24^{\circ}$ of Nice. Again, the Barbarian of the Saints, as the young lady on the box seat calls our host, tells us that the hot, burning winds of Southern Europe are never known here, that this is the only true paradise, the real land of dolce far niente, the home of the gods.

The quiet old town, with its fine hotels, long asphaltpaved streets, its miles of gardens and splendid drives; 


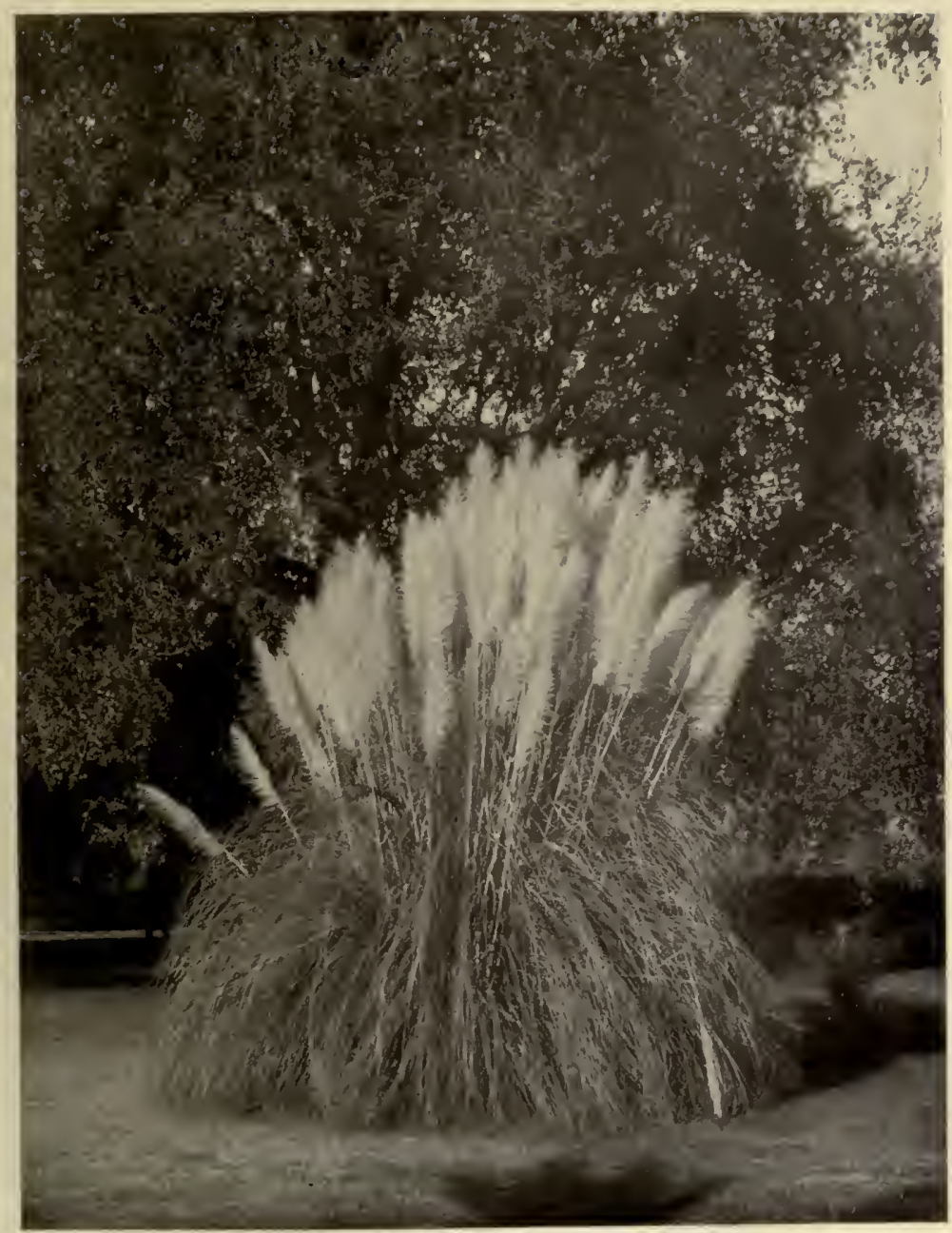

Pampas Grass, San Diego, on El Camino Real. 



\section{El Camino Real}

shops for the sale of curiosities; its Chinatown, where the odour of opium and firecrackers mingles with the perfume of flowers; its long wharf, yachts, and vessels, all offer inducements to tarry. Parts of Spanish-town still remain inviolate, and we are told of the glories of the old De la Guerra mansion, where Richard H. Dana witnessed a marriage festival in 1836 . The family is still living in Santa Barbara. We buy a reboso, an Indian basket, from an old Mexican woman, "for luck," the driver puts it, and are away up the fine, hard road to La Patera, where the Indians buried their stone mortars and household gods in the long ago.

Near here we drive through the fine ranches of Hollister, Cooper, and Stowe, the former known as "Glen Annie." "Ellwood," the Cooper homestead, is famous for its olive orchard, the largest in Southern California, also in America, with works the perfection of neatness, over which the courteous host takes us. The home is embowered with flowers from every clime, a garden the year round. From here we pass for several miles up the picturesque little cañon by the side of a stream and beneath trees that were young in the days of the Franciscan padres, and, finally, at the head of the ravine, halt for a consideration of the well-filled hampers which the coach is made to disgorge-for this is a feature of coaching in Southern California; the midday meal is carried, and a picnic is enjoyed in some nook or corner that may meet the eye.

From this region numerous trips can be made to 
glens and eyries which in their beauty compare favourably with those of European resorts : the Gaviota Pass, the Valley of the Santa Ynez, the mountains rising to the east, while to the west the ocean is seen here and there, a reminder of the extremes that Santa Barbara affords. Here the lover of the picturesque may spend weeks without exhausting its beauty. But we are off again, rolling down to the beach, with its long line of shining sands, calling to mind New England shores. But here, they tell us, the water on this February day has a temperature of sixty-one degrees, about that of Newport in June. Tourists are enjoying the surf ; the splendid palm-lined beach is gay with riders, while the castellated rocks on the north are dotted with strollers from the big mission-like hotel near by. Over beyond the blue stretch of water that forms the Santa Barbara Channel rise the Channel Islands.

We could have reached the Ojai Valley, thirty-seven miles south-east from Santa Barbara, through the Cacitas Pass, but preferred to go by the Mission of San Buenaventura, thirty miles away. This took us through the delightful suburbs of El Montecito-with its hot sulphur springs far up the cañon, thirteen hundred feet

- above the sea, where the Indians resorted years ago,--by nooks and corners of the Santa Ynez, the San Marcos Pass, and the Painted Cave and Rocks.

The stage road winds along the edge of the shore, gleaming sandy crescents succeeding one another in endless variety. Through the orange groves of $\mathrm{El}$ 


\section{El Camino Real}

Montecito we enter Carpenteria and its slopes. Here a peculiar patch of black ground being ploughed by a Mexican catches the eye of a scientific coacher, who pronounces it the site of an ancient Indian village. The Mexican stops work as the coach slows up, leans upon his plough, and while rolling a cigarette sententiously answers the questions thrown at him singly and in pairs. After much solicitation, he finally enters the adobe near at hand and returns with some of the results of his ploughing, ancient relics turned up in former barley seasons: a stone mortar, some abalone shells, the holes stopped with asphaltum, the dishes of the Indians, bits of soapstone with perforations, arrowheads of flint, and a flute that some ancient had manufactured from the wing bone of a bird. It is rudely made, and ornamented with bits of pearl from the abalone. Beads of shell and a flint knife complete the treasures of this collection.

"Who were these people?" asks some one.

"No sabe, señor," puffs the Mexican.

He might have said that his house was resting on a veritable kitchen-midden, a town-site of the early Californians, which Juan Rodriguez Cabrillo discovered when he sailed up the Santa Barbara Channel nearly three hundred and fifty years ago. He might have said that the adventurer found this land the site of many villages, where once lived thousands of happy natives. He might have told us that his ancestors were of the party, and that they buried the great captain, Cabrillo, 
on San Miguel, where he still sleeps. But in point of fact he said nothing and looked in stolid amazement at the volubility and learning of the American whip of the strange vehicle.

Our road follows the beach through Carpenteria, past graceful sand-dunes where rich grasses grow, where the faint track of sea-birds is seen and the roar of the surf breaks gently on the ear. Beyond lies the ocean, as smooth as a disk of steel, with beds of kelp floating lightly on its surface-the resting place of the gull and otter; and here the sail of a Chinese junk, the green slopes of the Santa Ynez on the other side, and little cañons reaching down to the shore, playing a veritable game of hide-and-seek with the gleaming ocean. Now an adobe ranges into view, with its barren, well-worn door-yard, its ramàda, and garlands of chillies, red and glaring, its hairless dogs, and dark-eyed children who have never seen a red and yellow coach and who stare hard and long, silent at the melody of the horn.

Down we plunge into the little arroyo, splashing across the clear brook that, with its sparkling sands and dashing trout, comes gurgling down under the arcades of alder and willow; up the bank with a rush, winding through a grove of live oaks where the tap-tap of the woodpecker echoes, and the gray squirrel flashes his foxlike tail; out into the fields again, on to the road lined with yellow violets, bluebells, cream-cups, daisies, poppies, bluettes, and other wild flowers that seem to reach far up to the manzanita forests of the upper slopes. 


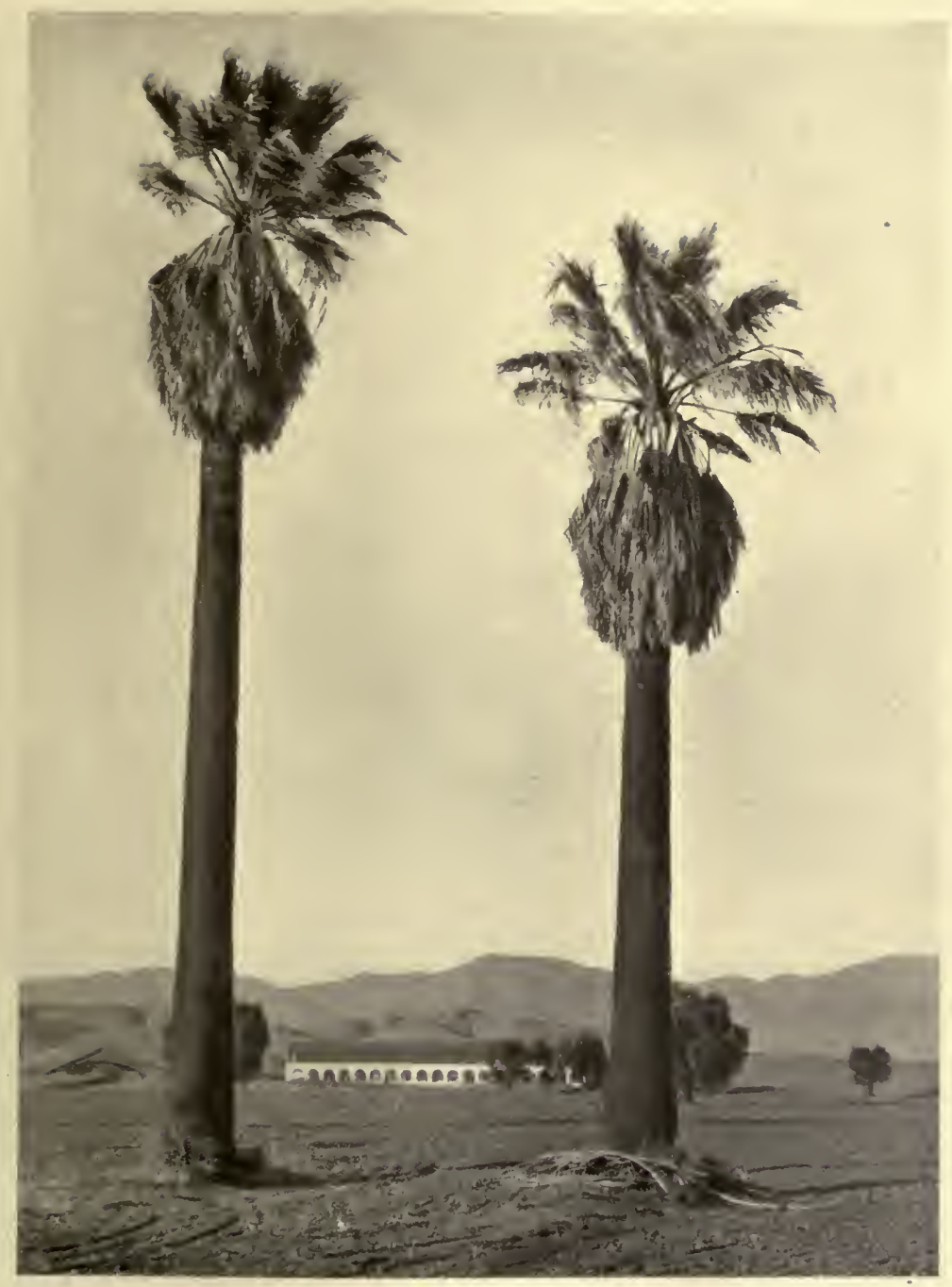

Palms of the Mission of San Fernando Rey on the King's Highway. 



\section{El Camino Real}

From the hillside comes the note of the valley quail, then the roar of its wings. The nest of the wood-rat hangs on a limb; the air is filled with insect life dancing lightly in the sunbeams, all on this winter day.

And so on we go, over the same road that Father Junipero Serra and Governor Felipe de Neve with their guard of sixty soldiers passed when marching to found the Presidio of Santa Barbara one hundred and nine years ago, and with a final burst of speed, ride bravely into the old town of San Buenaventura, cross the shallow river that creeps lazily out from the grove of alders and willows, round the big hill that divides the town, and passing the shadows of the old Mission of San Buenaventura seek the more material comforts of the Inn of the Roses.

In and about San Buenaventura there are rides of no little interest. The Ojai Valley is but a few miles away along a seductive trout stream that successfully woos the coacher; but the old Mission is the piece de résistance, and one cannot contemplate these old piles, almost the only historic ruins in America, without being impressed with the energy, courage, and faith of Padre Junipero Serra and his followers, who built this chain of Missions up and down the coast for six hundred miles; a region infested with Indians, and at that time with wild and dangerous animals.

The San Buenaventura Mission, which was founded in $178_{3}$, is small, but well preserved. It has a large belfry or bell tower, a large enclosure, but lacks the 
more pretentious Moorish architecture which characterises some of the other Missions. Yet the padre tells us that early in the nineteenth century this was one of the wealthiest of this great chain, possessing vast flocks and herds under Padre Francisco Dumetz and Vincente de Santa Maria.

From San Buenaventura the road pitches down into a wide valley, and we ride by the sea, which has a long fine beach from which can be seen the jagged points of Anacapa Island. We pass through Hueneme, then turn to the east, passing Camulos and so on to San Fernando.

Up through a delightful country we roll along, stopping for the night at Santa Paula, the following day reaching San Fernando Valley, and the Mission of that name, that has long been one of the attractive ruins of the State. Here we see some of the tallest palms in Southern California, the remains of the old Mission olive grove, and a long line of splendid Moorish arches and tiled roofs, preserved from utter destruction by the Landmarks Club of Los Angeles. The padre tells us that Lasuen dedicated the Mission in 1797 , and that the present ruin dates from 1806 , being named after King Fernando III. of Spain, who was canonised in $167 \mathrm{I}$ by the Pope.

At this time of the year San Fernando is a garden. The chaparral is rich in greens, and the songs of the mocking-bird and the meadow-lark are heard on every side. Rising to the south are the green slopes of the Sierra Santa Monica Mountains that finally leap into 


\section{El Camino Real}

the sea. The old Mission is deserted. Bats flit about its beautiful arches at night; the strong west wind sweeps through its adobe rooms unobstructed, and one tries in vain to reconstruct the principality of eighty years ago. Yet it was the centre of great groves and extensive vineyards; it had flocks and herds, and \$9o,ooo in cash; but in 1846 it was sold by Governor Pio Pico for $\$ 14,000$ to carry on the war against the United States. San Fernando is still picturesque in its decadence; the resort of artists, poets, and lovers of the beautiful.

Los Angeles is but a few miles distant, but the coach keeps to the left, along the foothills of the Sierra Madre, and enters the Cañáda through a series of fine ranches, and so passes out into the San Gabriel, crossing the Arroyo Seco above Pasadena, a charming and modern city, the centre of tourist interest in Southern California, abounding in fine hotels and drives, and remarkable for its climate, winter and summer, the best test of which is the long list of well-known men and women of the East who have made their home here.

Pasadena is but four miles from the wall of the Sierra Madre, nine miles from Los Angeles, and tl see from the old Mission of San Gabriel, in the town of that name. Of all the valleys of Southern California, the San Gabriel is the richest, the most beautiful ; and climbing to the summit of Raymond Hill, which the genius of Walter Raymond has made famous, the coachers are confronted with what is doubtless one of the most 
remarkable spectacles in the world,--winter and semitropic summer face to face. The Sierra Madre are white with snow, a long range as high as Mount Washington, and farther to the east Mount San Antonio, ten thousand feet in air, and Mount San Jacinto, still higher, -domes of purest white against the azure of the cloudless sky.

Drop the eyes and they rest upon the garden spot of this country: thousands of acres in the highest state of cultivation, groves of orange, lemon, olive, walnut, and nearly every fruit; great vineyards; groves of eucalyptus and live oak, telling the story of life in the open in a land of balmy airs and eternal summer. Here are some of the notable California ranches, as Sunny Slope and Santa Anita, with their fine reaches of forests, their lofty palms, and seemingly endless lines of orange trees, ranch houses embowered in tropical verdure, and the ranch property reaching away for miles toward the distant sea.

The coach rolls through great vineyards, and everywhere evidences of the highest cultivation are evident. Later, at the vintage, gangs of Mexicans, men and women, can be seen picking and filling their boxes with fragrant Mission grapes; no more delightful region for coaching or automobiling can be imagined than this.

Pasadena is a city of 25,000 inhabitants, recruited from among the wealthy and cultivated people of the East, and is said to be the wealthiest town of its size in the world. It stands in the literal heart of an orange 


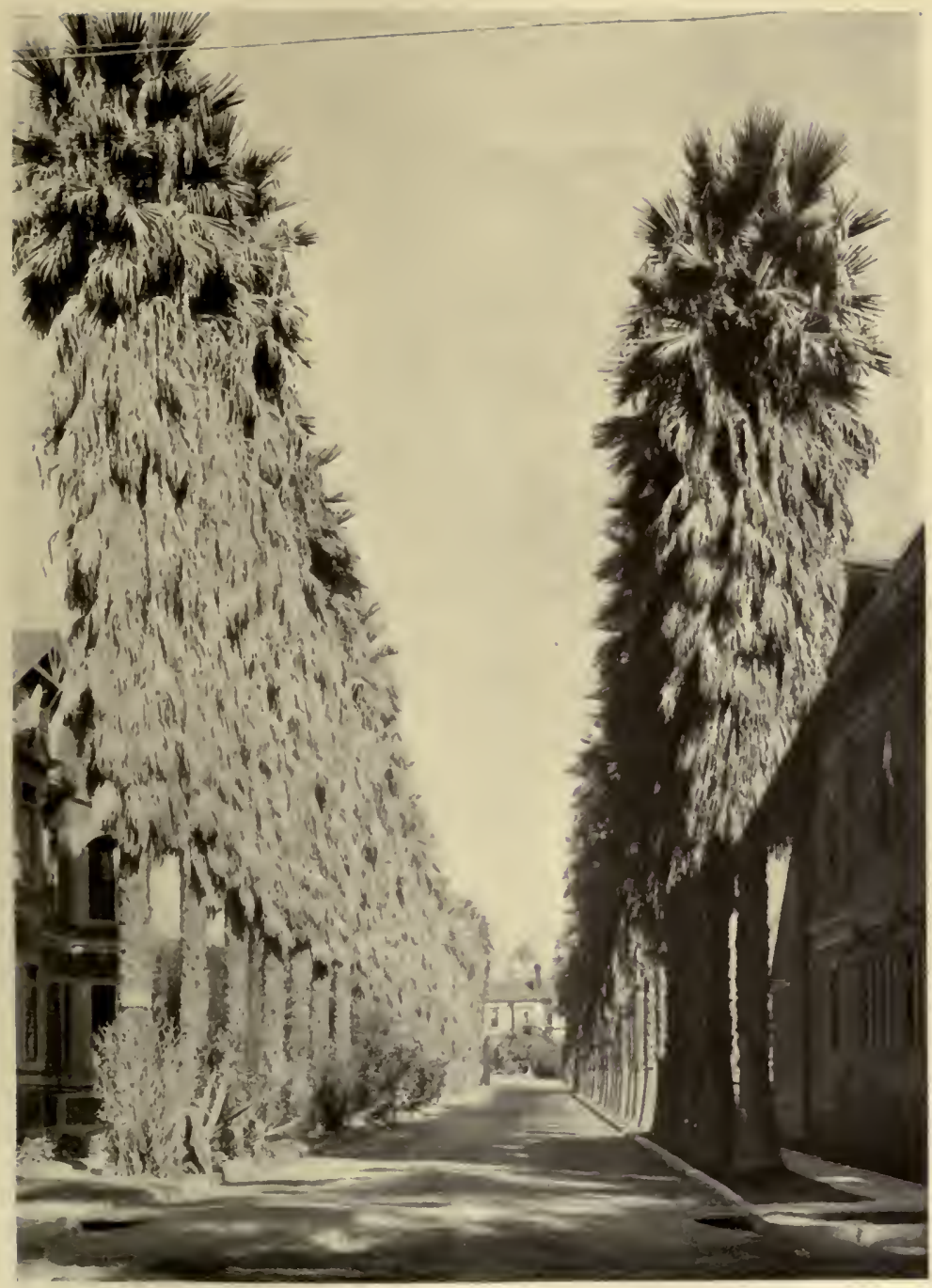

An Avenue of Palms, Los Angeles. 



\section{El Camino Real}

grove, and in winter is a garden environed by snowcapped mountains, and its present size and fame are due to its beauty of situation and its singularly perfect climate. Thirty miles from the ocean, on the slope of the Sierra, it commands the sea: receives its winds by day, and mountain air by night. Pasadena exemplifies life in the open in Southern California. Its country clubs, golf links, fine roads and drives for motor-cars make it at once the centre of delightful life in what is fast becoming a fashionable winter resort comparable to Nice, Florence, or many cities of the Riviera, and exceeding them all in the perfection of its climate.

As the coach turns to the south and passes through the long orange groves something comes down the wind from far away,- the bells of San Gabriel Archangel, the same tones that rang out the Angelus years ago and invited the savages of the valley to a better life.

There is a variety in this out-of-door life that lends an additional charm to the country, seen from the top of a coach. The yellow splendours of the meadow-lark's breast blaze for a moment on the mesa; plumed quails run into the road, stop and eye us, then hurry along, with nodding plumes, to rise almost under the leaders' heads, and fill the sleepy air with the thunder of their wings. Early in the morning cotton-tails, fluffy and tender, may be seen darting in and out among the cactus; or in some wash, in the shadow of the sage-brush, sits a longeared hare, which darts away, bounding into the air as though on springs. Little gray owls nod at you from 
the fence-top as you pass; and on the hillside, through some cañon, a monkey-faced owl stares stolidly and refuses to move, charmed or fascinated, mayhap, by the rattle and clank of the coach. In the fields are groundsquirrels, living underground, and on the edges of the laguna blackbirds make merry-some standing on the backs of pigs and riding about. Rolling through the chaparral, the attractive paisano or road-runner, with fiery eye, runs ahead, refusing to take to the brush, until nearly caught, then rising and flying low to plunge down again. Countless small birds fill the air with melody; a big bluebird cries loudly as it dashes into the wild lilac or sumac; and at all the ranches the finches or linnets swarm, devouring the fruit, and often silencing the rancher with their marvellous song.

We follow up the sound of clanking bells and enter the narrow streets of San Gabriel, with its adobes, and stop in the shadow of the old Mission that to-day stands like a fortress defying time, an imposing and picturesque monument to the devotion of the early padres to the cause of Christianity.

San Gabriel Archangel, which was founded in I77I by Padres Cambon and Angel Somero, was originally one of the finest and wealthiest of the Missions. Its long buttressed building is suggestive of strength, and, it is said, repelled many an Indian attack in the early days. It is the second building of the Mission, begun in 1775 and finished about twenty-five years later. Still 


\section{El Camino Real}

to be seen are remnants of the great tuna hedge that once surrounded the Mission property-an impenetrable barrier against enemies.

The padre takes us into various rooms in the Mission, reverently displays the rich vestments and old records in Padre José Maria Zalvidea's handwriting, from which we learn that the first Indian was baptized in $177 \mathrm{I}$, and in the first twenty-five years of its history over four thousand Indians were baptized there. San Gabriel once owned hundreds of acres and vast herds of cattle. The belfry is picturesque, and has four bells which still call the faithful down the valley of San Gabriel. The old Mission was repaired by J. De Barth Shorb, several years ago, and is still in use by the people of the vicinity, who, despite the American invasion, cling to San Gabriel and its memories.

In all probability El Camino Real extended down the San Fernando Valley to Los Angeles, from here to San Gabriel, then possibly through the break in the hills near Whittier, so leading to San Juan Capistrano Mission. But the coachers propose to diverge and reach Pala Mission by the mountain or upper road, regaining the King's Highway upon the return trip along-shore.

Down the valley, by Monrovia, Duarte, and Azusa, the coach bowls, passing through a continuous garden, stopping at Pomona for the night, then on by Ontario, Cucamonga-famous for its wine,- - to Colton and Riverside with its splendid vistas of orange groves, its long rows of palms and magnolias. We tarry in this splendid 
semitropic garden a day or two, and one morning take the road to the south-east for Pala. The road carries us to the east of the Temescal range ; crossing the San Jacinto River, that rises in the great mountains to the north.

The night is passed at Perris, and then we move on to Lake Elsinore, backed against the green hills. From here the road winds along to Murrietta, at the base of the Santa Margarita range, where a great ranch rests on the top of the mountains, well repaying the climb. From here a magnificent view over Riverside and San Diego counties is had,-mountains and hills everywhere tumbling away toward the sea.

The drive from Murrietta to Pala is of much interest and takes the coachers through little valleys of wild oak, past Temecula and the great ranches of Gonzales, Santa Rosa, Pauba, Wolf, and others. These and the picturesque tule houses or huts of the Pachango. Indians enliven the miles as they slip away. Then there are the stops for luncheon beneath great live oaks, new vistas of old and familiar mountains that rise, colossal barriers, against the heated desert.

Soon the coach turns down the road by Mount Palomar, part of which is hewn out of the solid rock. Here is coaching indeed, and everywhere are found evidences of the tremendous forces of nature which have rent and torn this mountainside. We pitch down from the highlands and come out into the little valley of Pala, in which is Pala Mission, and the home of the Warner Ranch Indians. 


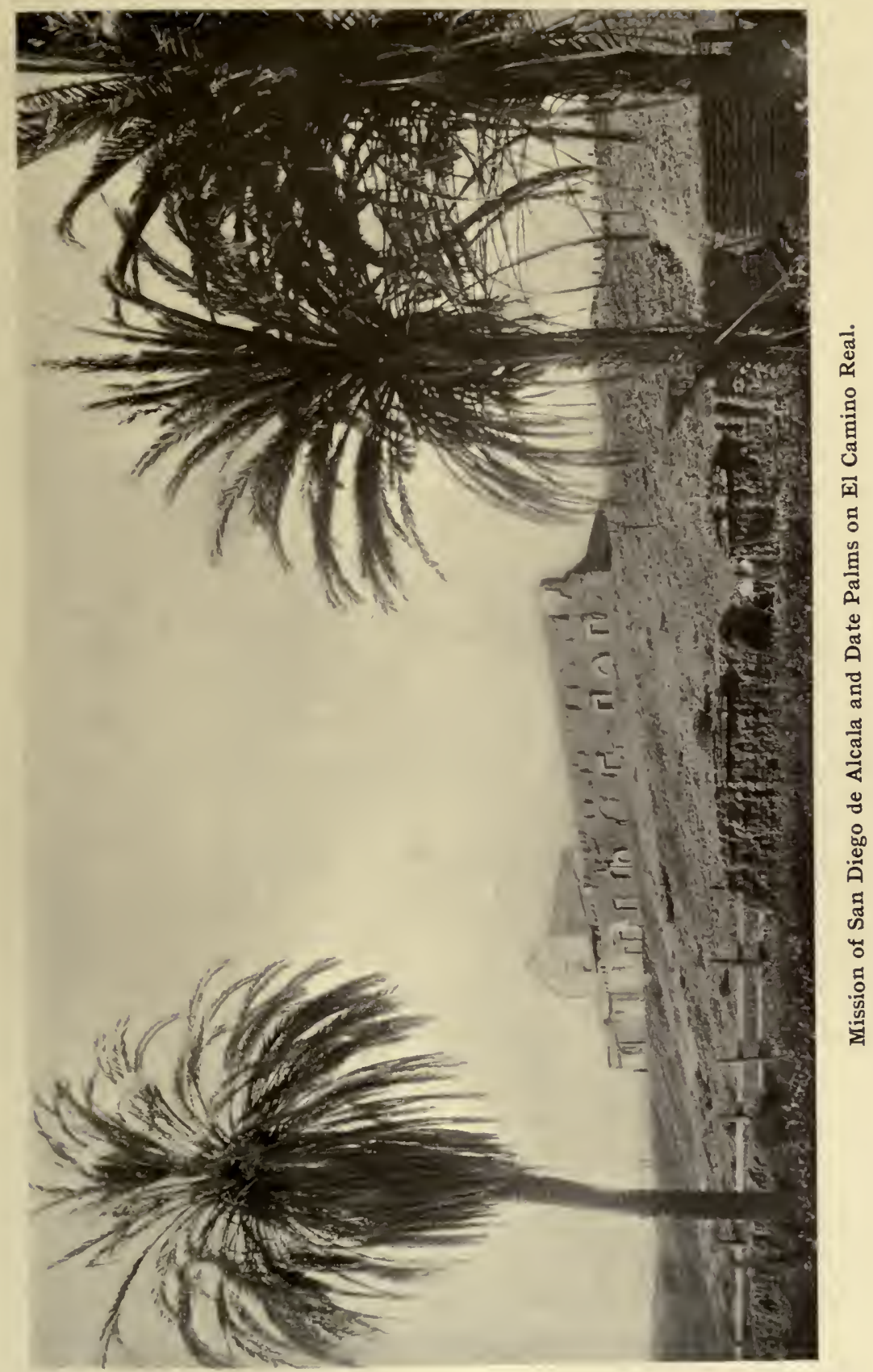





\section{El Camino Real}

I first visited Pala and Pauma, ten miles nearer the desert, to see the Fiesta of San Luis Rey. A ramáda had been built, an oblong shelter of brush, arranged with booths along the sides, in the centre of which was the dancing-floor. All the country people, the first families and all the rest, for miles around, had come in, mostly Mexicans, and a scattering of Indians, who were camping in the vicinity. During the day there were horse-races and games of various kinds. The old Indians danced and sang, but the chief display was at night when the ramáda was lighted with lanterns. It was " on with the dance, let joy be unconfined," in the most solemn fashion. The ramáda was a miniature village. One booth was a butcher-shop. The owner of the next sold fruit; then came a barroom, where "dago red" and poor whisky were retailed. A monte "outfit," or the wheel of fortune, followed, or roulette; and in the next the national game of poker was exploited by several gentlemen of fortune from Los Angeles.

As darkness grew apace, the young Mexican women took seats around the dancing-floor, and a violin and guitar began to pour forth the melodious strains of La Paloma. A young man would steal up behind the woman of his fancy and break a cascarón on her raven locks-they were all raven-and over them would fall, like snowflakes, masses of gold, silver, and coloured paper, which had filled the egg. It was a Spanish invitation to dance, and the lady thus decorated rose, 
bespangled and blushing, and accepted, the two beginning an interminable whirling, often confined to a few feet. I watched this báile most of the evening, but in all that joyous period I did not hear a laugh or see a smile; surely the Mexican takes his pleasure seriously, at least at Pala. When the dance was over the maiden was released and took her seat, the gallant going out to smoke, play, or drink alone. Let us hope that he quaffed to one of the serious maidens left silent and alone on the floor of the ramada.

The old chapel Mission of San Antonio de Pala, now an interesting ruin, was founded by Padre Peyri, and is an excellent example of the crude early Mission. The long chapel is of stone or adobe, and contains a life-size statue of San Antonio de Pala; also one of St. Louis, King of France, which is borne up and down the plaza on feast days by the devout Indians. Pala was founded in 1816 , and differs from all the Missions along the King's Highway in having a disconnected or isolated belfry which stands out distinct, alone.

From Pala the road turns to the west, and we follow the creek toward the sea. It is impossible to convey an idea of the charm of riding through this land of dreams in the dead of winter. The country is carpeted in tender greens; great masses of star-eyed flowers cover acres, and roll away like the waves of the sea, lost in the distance. Here the red of painter's-brush lends a flush to the mesa, and the air, soft as velvet, fans the cheek, an elixir of health. The flute-like song 


\section{El Camino Real}

of the meadow-lark comes with ringing notes from every mesa; among the eucalyptus leaves, long and fragrant, the golden oriole is singing, and in the live-oak grove are heard the tender notes of the mourning dove. The sun has a golden radiance, the sky is azure, but not more blue than the distant sea that gleams brightly somewhere far down the cañon, where wild geese dot the laguna, and sand-hill cranes stand like sentinels along the tall sea grasses.

We pass the San Luis Rey River, Fallbrook, and finally the coach rolls into San Luis Rey de Francia, and is again on the King's Highway, as in all probability it once ran up and down the coast, having made the inland tour as described. San Luis Rey, while a ruin, is a sumptuous pile, and originally was one of the finest Missions in Southern California. It was dedicated in 1798 by President Lasuen and Padres Santiago and Peyri. Contemplating the ruin to-day, it is difficult to believe that the Mission once owned 200,000 acres of land, over 40,000 head of cattle, and raised yearly 20,000 bushels of grain, not to mention the making of 200 barrels of wine.

San Luis Rey was a principality in every sense, and the traveller along the King's Highway years ago received a gracious hospitality from the padres, who blazed the trail of civilisation from Mexico to San Francisco, and beyond, establishing a chain of Missions that are monuments to their energy and purity of purpose. The splendid pile was one hundred and fifty feet long, fifty 
feet wide, and sixty feet high, its walls, like those of San Gabriel, being four feet thick. A fine tower graces the south side, and is pierced for eight bells. The corridor has two hundred and fifty-six arches. Its fine dome, its groined arches, the Byzantine pulpit, the long corridors, appeal to the imagination, and make the old Mission one of the really beautiful pictures of Southern California, whether seen against the green slopes of winter or on the barren mesa in summer, when its tints and shades seem to blend with the soil.

The Mission has been repaired by the Franciscans who now occupy it and tender visitors a courteous reception. They relate fascinating stories of the days of Zalvidea, of the Indians saved; and one is glad that the old Mission is rehabilitated and not allowed to go to decay.

San Luis Rey is about eighty miles from Los Angeles and four miles to Oceanside, from which the coach turns away to the south along El Camino Real, or as near it as possible; a trail along which Serra and hundreds of the padres of old and the soldiers of Spain walked. The run to San Diego Mission is about forty-seven miles along-shore, passing towns and hamlets, through great ranches, and over a charming country, in its coat of green. Off to the east are the San Ysidro Mountains and lofty Cuyamacha and Santa Margarita. There are countless little lagunas along-shore, often filled with ducks. The roar of the wings of quail fills the air, and the delights of life in the open are emphasised in the 


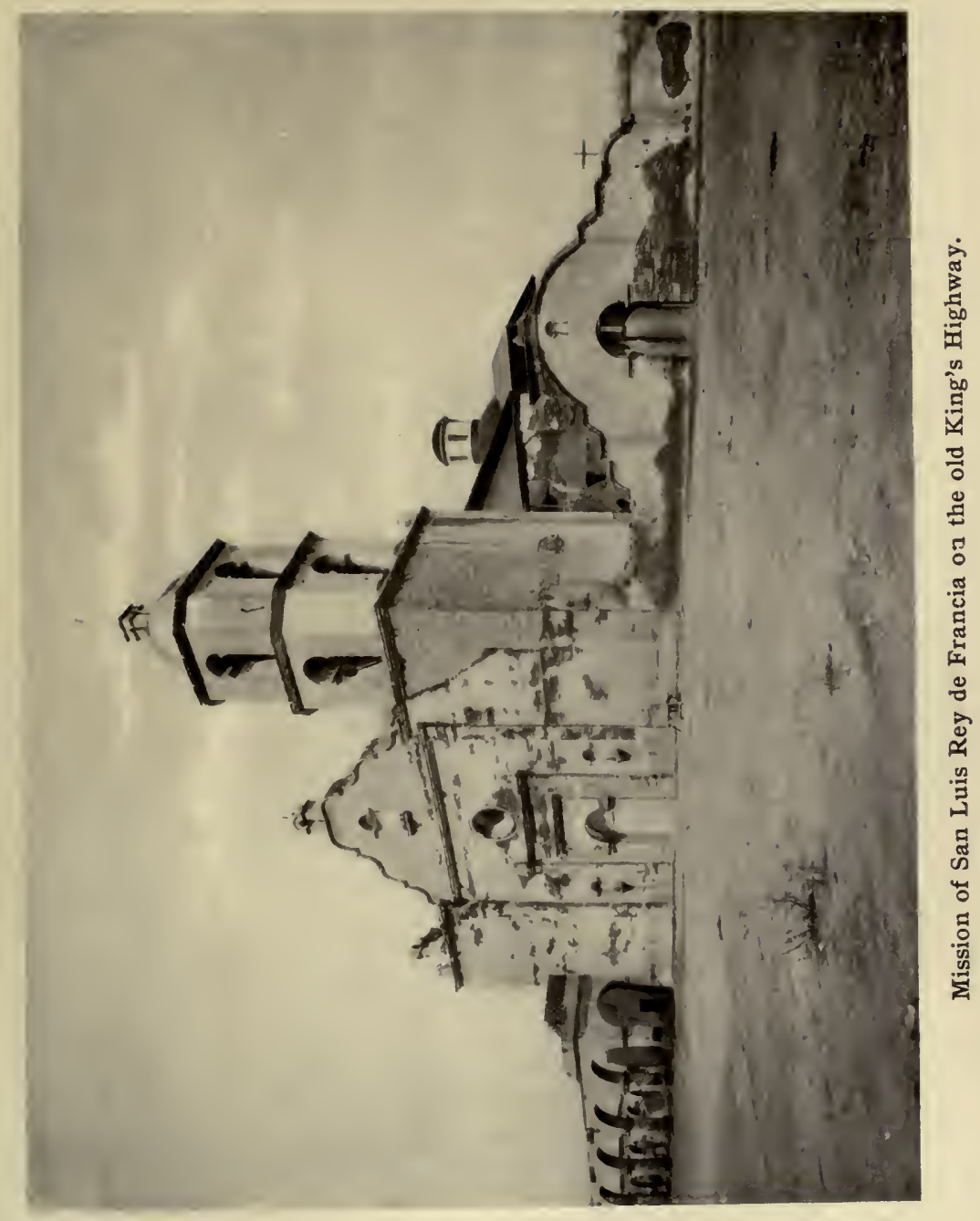



very joy of living in this land of soft winds and perfumed air. Then there is the charm of the roads themselves, running up over mounds of green, winding down into little cañons that tell of the sea; not always smooth or like a real King's Highway, but full of promise and possibility, and consistent in the realisation. Now we are led by a long-necked paisáno that paces like ecstatic; now blocked by a flock of quail that cry "Hands up !"wook-wook-wo-you can translate it yourself. There is always some siren of the road to lure you out into the fields and far away to distant mountains that lie faintly on the edge of the world to the east.

We exchange opinions with the passers-by and the owners of the ranches who come out as we pull up at the slightest excuse. Then there is the fund of wisdom drawn from the country store, and its habitues, all adding to the charm of coaching or automobiling in the land of the setting sun.

Slowly we move down the coast; now crossing some little river-bed near the sea, again high on the mesa; stopping at Carlsbad - a strange name for a California King's Highway; at Encenitas and Del Mar, which are better, enjoying the fine beaches, the quail and duck shooting; and one fine day we reach the end or the beginning of El Camino Real-the Presidio of San Diego.

Here is the first of the Missions of Upper California, founded by Padre Junipero Serra in I 769 , and while once rich and prosperous it is a complete and sad ruin to-dasy ; adobe walls and old palms alone tell the story 
of the thirty thousand, or more, head of stock it once owned, even as late as 1827 . Near the old crumbling walls are two ancient date palms, which must have been planted in the days of Serra.

Crossing the bay we roll up the fine road to Coronado. San Diego is a delightful country for coaching ; there are good roads everywhere and climate of the perfect variety. We go to Tia Juana and cross the line; then to La Jolla and the home of theosophy; spend delightful hours in the famous patio and garden of Coronado-which may be considered the beginning of El Camino Real in the year of our Lord 1905. They will show you at San Diego the man who came to stay a day and who refused to leave under any circumstances. He telegraphed for his family, and at eighty is growing up with the country. We easily see how it is possible.

The return to Los Angeles, 127 miles north, is over the King's Highway as near as we can make it, and about forty miles from San Diego we dip down into the opening of a river or cañon in Orange County and follow it up to the old Mission of San Juan Capistrano, which stands on high land with the Santiago range behind it and lofty cliffs or mesas between it and the sea. We follow the cañon slowly, passing through ranches of walnut and groves of trees, coming out at San Juan with its ranch houses, its quaint inns, and the fine old Mission, half ruin, where one might wish to tarry indefinitely. The Mission was founded in 1776 by Junipero Serra. Of all the ancient piles this appeals most to the poetic 


\section{El Camino Real}

fancy. Its vast enclosure, its long line of arched corridors, the belfry, its tiled roof, the artistic chimney, the great dome, half fallen in, razed to the ground in the earthquake of 1812 , are all fascinating parts of the whole. It is impossible to more than suggest the charm of San Juan, but the coachers found it irresistible and tarried at the little inn. Portala, the first Governor of California, is said to have named San Juan Capistrano, having been impressed by its beauties of location, its restfulness, its tranquillity. San Juan is not only the land of mañana but of the day after, and then the air which brings the music of the sea up the cañon-but you must know it.

The coachers might have kept on the road to El Toro, Aliso, and so to Santa Ana over a good and fair country and through a region abounding in great ranches and olive groves, but they left the King's Highway again for a detour along an attractive beach, passing Arch Rock, reaching Laguna, on a little bay, at the mouth of a big cañon that comes plunging down to the sea from the upland mesa. Here there is a little hamlet and hotel, and the coachers have converse with a motor party who have come down from Santa Ana in one hour. The climb up Laguna Cañon to the upland mesa and the valley is one of the features of the trip, and then en route Laguna affords some of the best quail shooting in California, while the beach fishing for rock bass is sport of no mean quality.

Laguna has a charming rocky shore, to some extent unusual on the mainland in Southern California. Here 
the sea takes on marvellous shades and tints in the sunlight, and at sundown no place along-shore so appeals to the artist as this land of soft airs, sea odours, and melody.

One afternoon the coachers entered Los Angeles from the south. Perhaps they had lost the King's Highway; perhaps they were in the very footsteps of the old padre who walked up and down the coast, blazing this trail in the hot sands or yielding adobe. Who knows? Then, or in 1820 , when the old Plaza chapel was half built, the town boasted of but 650 souls; but this city up whose fine streets we pass has over 200,000 inhabitants in I g06. One can make Los Angeles in a day from San Juan, but the coach tarries at Santa Ana, Orange, Tustin, and El Toro, and their famous walnut groves and ranches of all kinds are visited.

I have hoped in this brief recital, an enumeration of some of the Missions along the old Highway, to suggest the charm of coaching and automobiling in Southern California, and the review of the Missions has been made merely to provide a motif or objective. A small party can make such a trip in a carriage or automobile, or even on horseback. Inns and hotels are scattered all along the old Highway, and the journey can be made with ease and comfort and the true charm of the country in the open enjoyed.

The old Missions of California are among the most attractive features of this country to the average person. They are typical California ruins and, like wine, will increase in value as time rolls on. Many of the old 


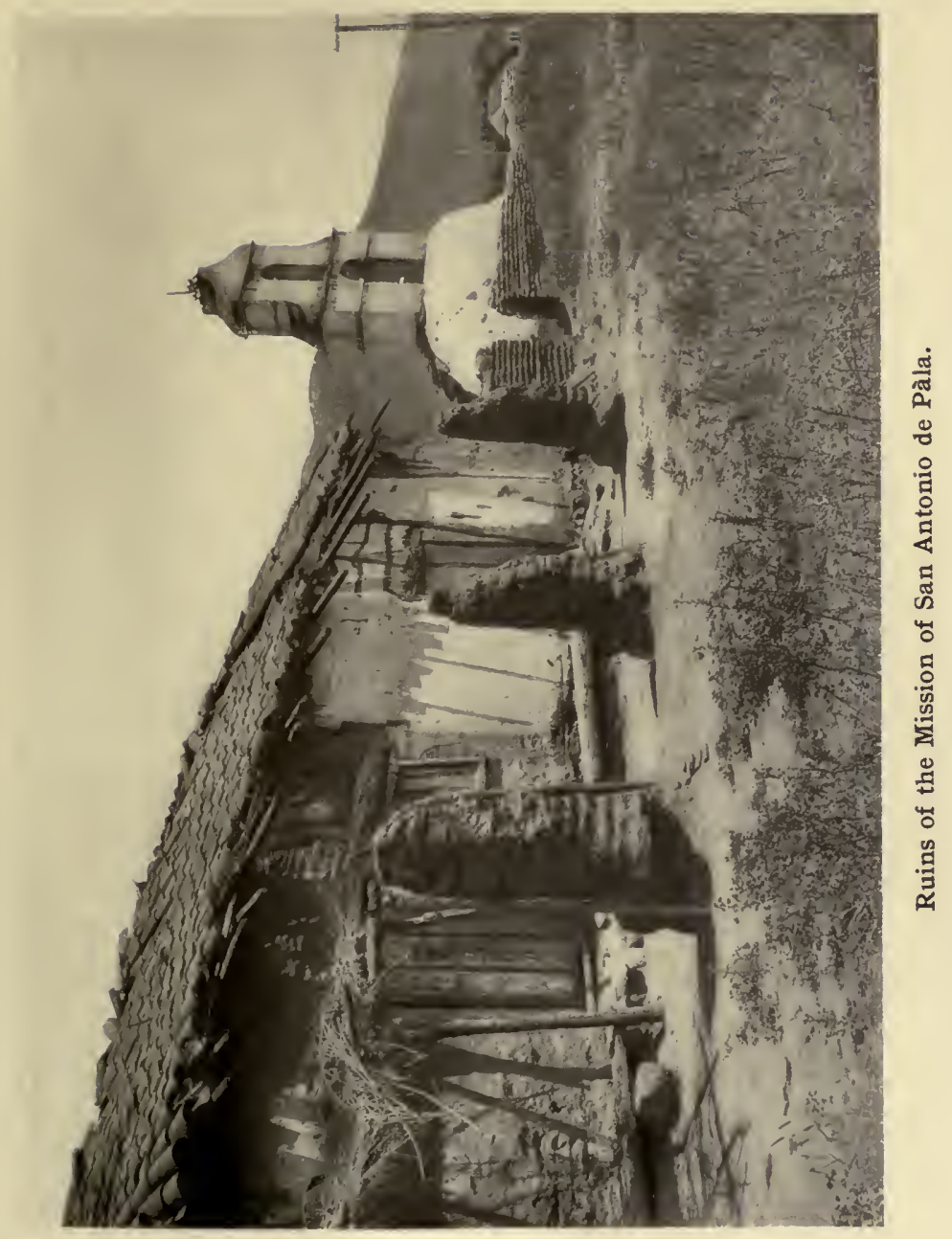





\section{El Camino Real}

Missions a few years ago were rapidly going to decay, but the Landmarks Club of Los Angeles has accomplished good work in preventing their destruction. The decay of San Fernando, Pala, San Juan Capistrano, and San Luis Rey has been arrested, and travellers through the fair country will now doubtless have the old Missions for all time, as their historical value is thoroughly appreciated by the present dwellers in the land of the setting sun.

I have made a coaching trip of another kind, in which hotels were not considered. The six-in-hand oldfashioned California coach was followed or preceded by a team loaded with the camping outfit. Captain William Banning was the whip and host; the best driver of a six-in-hand in California. The route was laid out in advance and six or seven tents were pitched every night, a cook and provisions being taken. This proved a delightful experience. Attractive locations for camping were selected along the route, the coach making the run from Los Angeles to San Francisco in about thirty days, no effort being made to make time. The following year this coach was shipped to San Francisco and the drive made about five hundred miles north; and on another season through the Yosemite. California can be seen from a car window, but to get in complete touch with the country it should be seen at close range, either in a coach, the saddle, automobile, or carriage. 



\section{Life in the \\ SierraMadre}

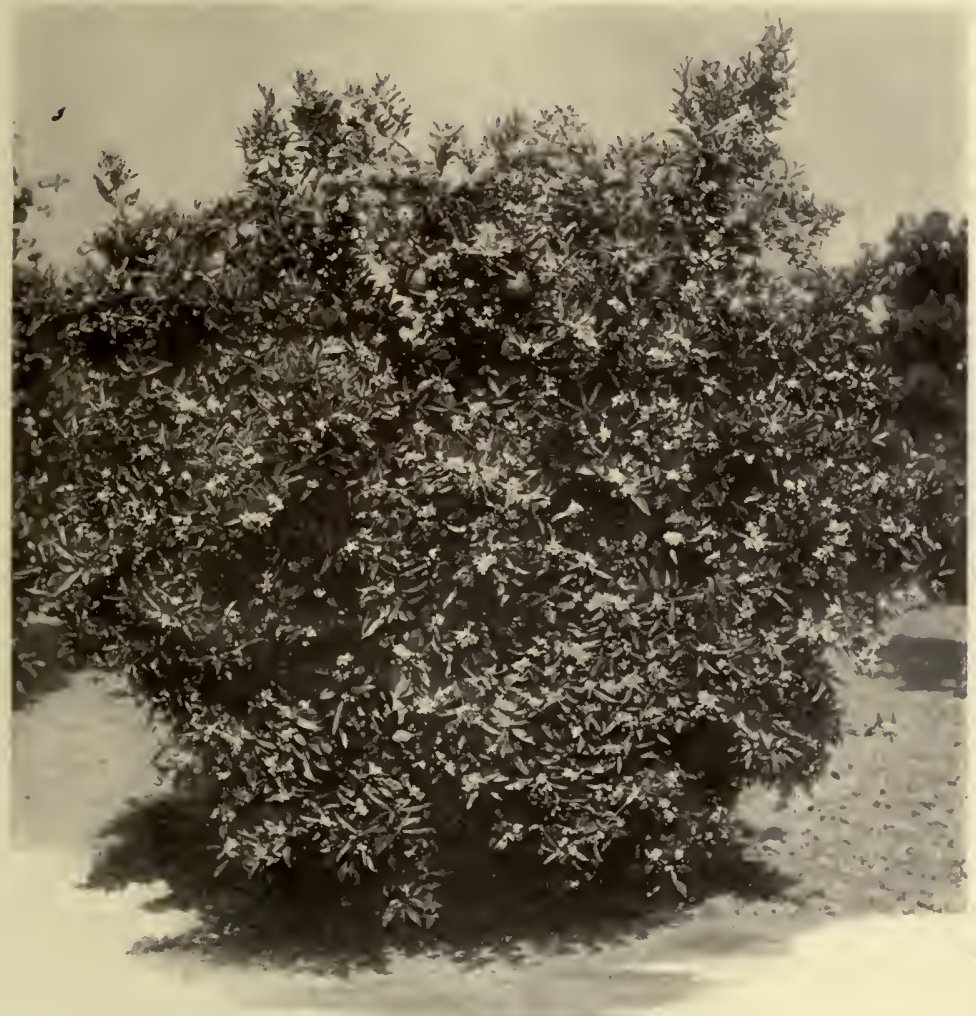





\section{Chapter XIV}

\section{Life in the Sierra Madre}

$7 \mathrm{HE}$ charm of continuous mountain life has given nearly every cañon in the lofty range one or more residents. When I first knew the Arroyo Seco Cañon, in 1885 , it had a dweller for nearly every two miles of its winding course. At the entrance, where he could look out into the broad wash, a bee-keeper lived; and over on a little mesa a miner, who sometimes showed me colour. On another mesa lived the Brown brothers, sons of John Brown of Harper's Ferry, and often as I sat in their cabin at night I heard stories of the Underground Railroad; and Owen Brown, pacing the floor, told of his escape along the mountains, lying in the brush for days, living on corn and travelling by night. The two brothers, Owen and Jason, were typical mountaineers, and for mere love of it would go up into the mountains, five thousand feet above the sea-for what? "To look out upon the earth and to think." Owen Brown told me that his father had this habit, and it was strong in him; a passion to climb above the 
world and look down upon its beauties. They built a trail nearly to the summit, that others might enjoy the mountains.

Half-way up the cañon lived one Judge Brunk, who held court where the trees formed a green arcade over the trout stream; and ten or twelve miles beyond you would come to Commodore Switzer's, who kept a little inn or camp where one could idle away the days in the very heart of the mountains.

This cañon was typical of nearly all in the range; mountain lovers being scattered up and down, fully satisfied with the isolation. I remember asking one if he never wearied of the life there, and his reply was "No." He referred to the trout stream that ran by his door, and the voices of the leaves that rustled music all the day. He understood it and loved the life, and so there are hundreds who like it all the time, and thousands who like it at times. I once lived six or eight months in the Sierra Madre, the location being a little plateau which sloped down, forming a cape between three deep and beautifully wooded cañons; there was no approach except by descending one of the cañons and crossing the stream; the locality being particularly isolated during storms. The place had many charms. The upper portion was at this time covered with chaparral, Adenostoma always green and in many tints, banks of sage, groups of wild lilac and ironwoods, while on either side the deep, abysmal cañon was filled with these and many more, alders, live oaks, sycamores, cotton- 


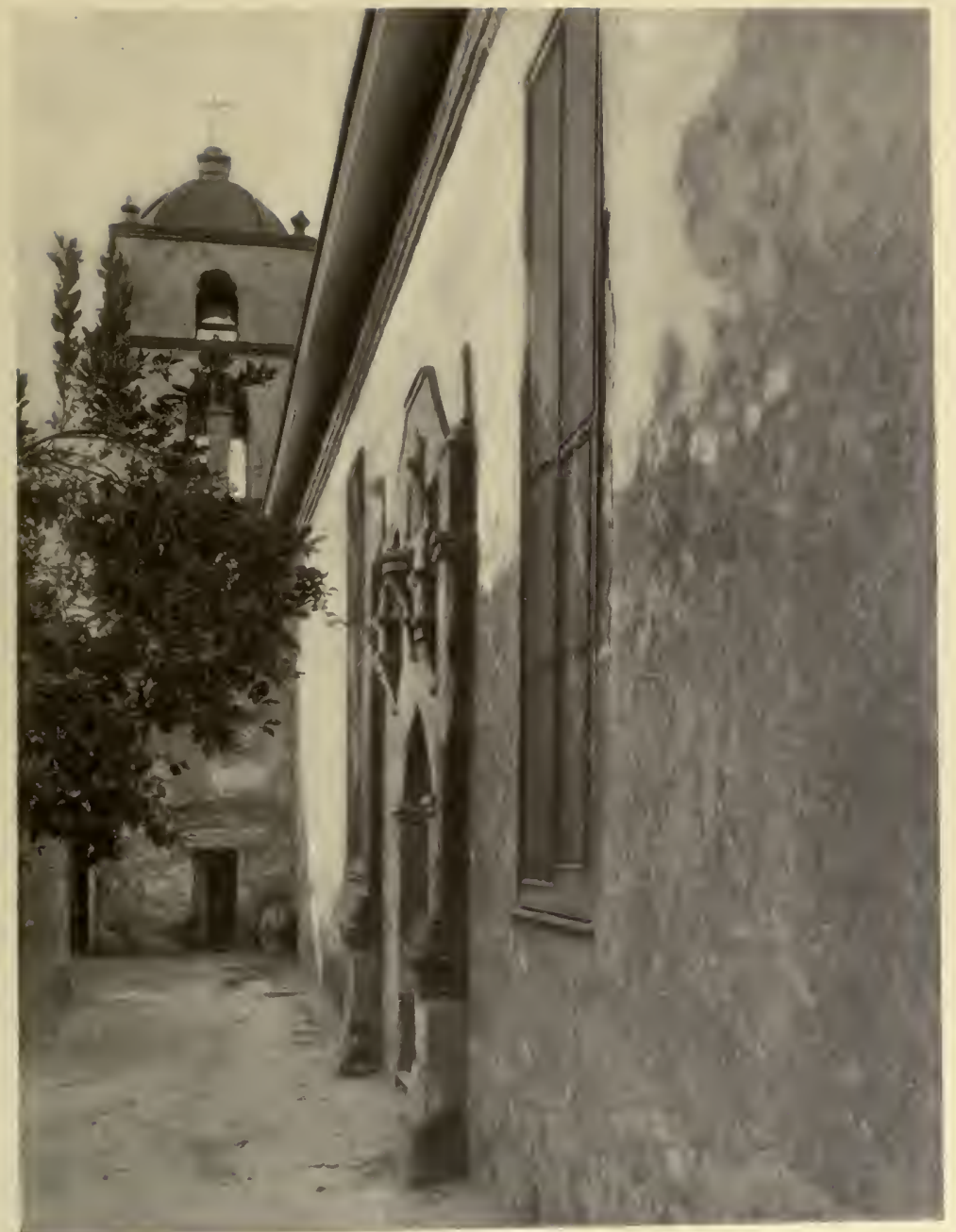

Mission of San Buenaventura on El Camino Real. 

woods, and bays, forming a silent river of green that wound down from the upper range, a river sinuous and beautiful. I could see the islands of the Pacific fifty miles away, and in the foreground the ranches, vineyards, and gardens of the San Gabriel Valley, merging into green hills to the right, and to the east melting away into other and more distant valleys, telling of Pomona and Chino.

Directly behind me rose the wall of the Sierra Madre, five thousand or six thousand feet in height, the first range of the mountains that for forty miles reached away to the desert. I could climb on to its face in a few moments and lose myself in its dense investment of chaparral, or I had the choice of three gateways immediately at hand-Millard's to the south, Negro immediately behind, and the Arroyo Seco to the west. In rainy seasons these cañons bore raging streams of water. Millard's was famous for its waterfall, and up the arroyo for twenty miles or more there were long stretches of rocky walls and mountain ranges merging into dark and distant cañons that seemed to wind away like living things, to be lost in other ranges far beyond. These mountain passes and the contiguous country became my range; I learned to know them well, and the fascination of the life, its absolute quiet, its tranquillity and peace, the beauty of the scenery, took a strong hold upon my imagination, and I could understand how some men could turn their backs upon the roar of great cities and live in the mountains. 
There was something restful in the quiet of the deep cañons; the music of the rippling stream as it eddied around the rocks, the rustle of the leaves, the high green walls and sinuous, deep blue sky river above, gleaming like a turquoise mosaic through the cañon branches, all appealed to the finer senses. The air was sweet, pure, vibrant, and cool, but never damp or humid, and in the summer months rarely too warm for comfort. In the winter, after the rains, each cañon became a garden of ferns and brakes, and the great halls of the mountains rang and reverberated with the resonant melody of falling, rushing water. Moving up the cañon into the higher areas of the range, its beauties increased, the trees became larger and more plentiful, and the sinuous trail wound and curved through pleasant arcades of green and graceful leaves which moved gently, softly in the wind.

At every step some new and charming vista appeared, now down into some little potréro where the sun sifted in, bathing the ferns with a golden light, or up some dark green branching cañon. Now the trail dipped down, and I looked far ahead into a green tunnel, formed by the cañon trees, or again came upon the sheer face of the fern-lined cliff, the abrupt wall of the Sierras, the trail rising higher and higher until reaching a little divide I could look out on to a great maze of tumbling mountains rolling away in every direction, an arabesque of cañon, valley, and chaparral.

There is something in the smiling face of mountains 


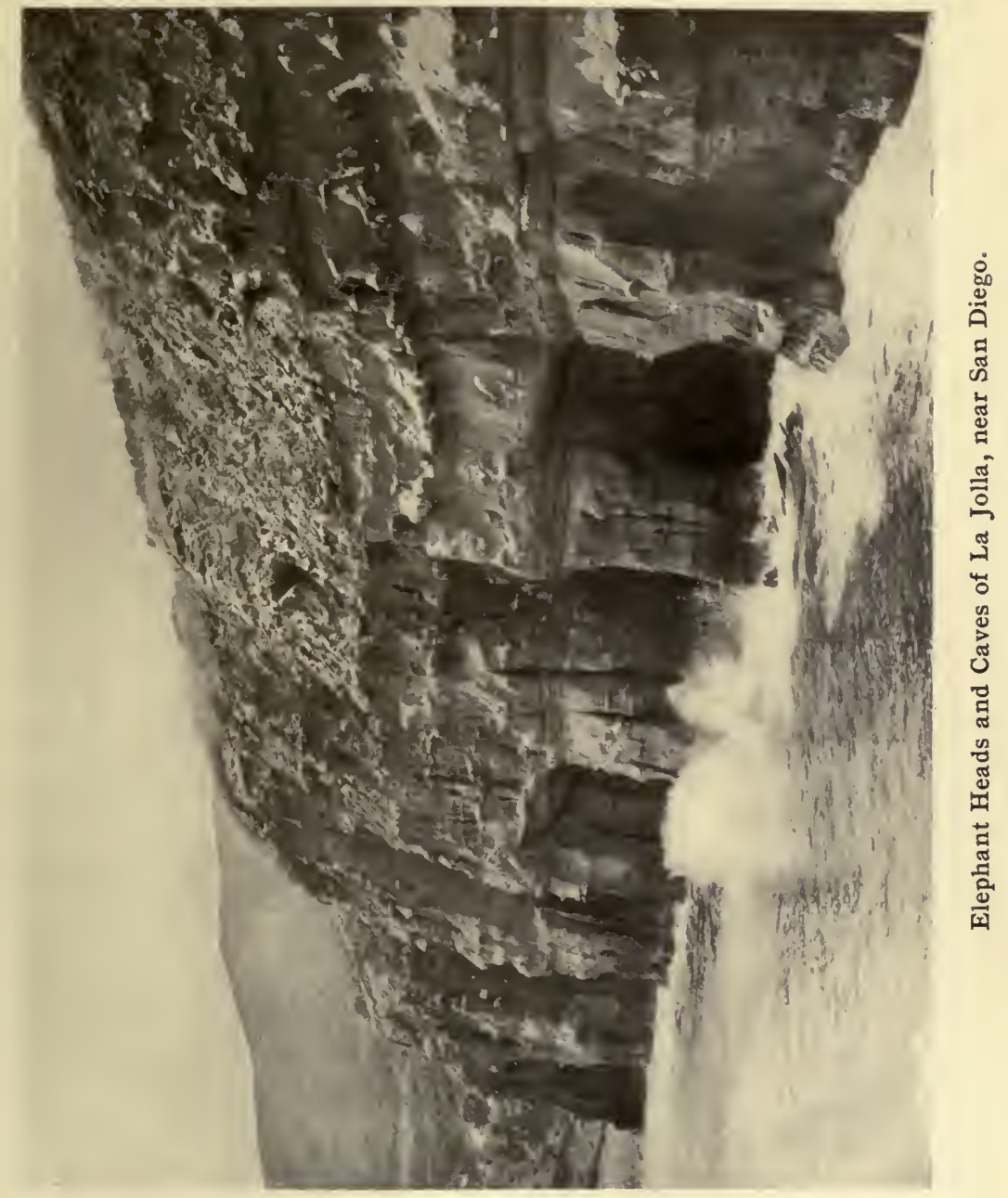





\section{Life in the Sierra Madre}

that takes strong hold of the fancy and imagination. There is an impulse to stop and bare the head before the works of the Infinite Designer of all these mountains, hills, and valleys.

In following the trail or the stream bed up some lateral cañon, there is a constant change. Shadows and lights flit, come and go; now the trail is through some dark green abyss, then broadens out into glorious sunshine, or again where deep shadows ripple down through the interstices of the leaves and dance and play across the trail.

Crossing the stream perhaps a hundred times, we reach the upper range and camp in the very heart of the forest. The arroyo flows by the camp, and up from the green abyss half a mile distant comes the vibrant roar of the fall, the joyous melody of the waters that are plunging on to the distant sea.

I have often walked down these cañons at night, when the tone of the wind is different; all day long it has been from the sea, now it blows from the mountains themselves, and from far away comes the murmur of the forest borne softly on, like the voice of the ocean. Now it is among the pine needles, rising and falling, a harp of a thousand strings, the soul of melody in its cadence. The cañon is deep in purple shades, and where the trail opens out the upper line is marked by stars, scintillating in intense brilliancy. The lateral cañons are of inky blackness, and the rush and melody of the water comes from mysterious and distant points. 
Over the divide is heard the laughing, yelping howl of the coyote and perhaps the mournful cry of the mountain lion. The air is cool and like velvet on the cheek, and has a remarkable carrying quality; the falling branches, the rolling down of mimic avalanches or slides of rock or gravel are distinctly heard, though far away, and every sound has its peculiar individuality.

I have stood on the high peaks at night and watched the fog cone stealing in from the sea, until it spread out an opaline vestment, filling all the valleys with seas of silver, through which the tops of hills and lesser mountains protruded like islands; a sea of marvellous lights and shades. In early morning it is vermilion or violet or silver, a splendid spectacle, as though the very air had frozen and filled the lowlands with a rolling, billowy sea of ice that stretched away to the horizon and wound its way around the limitless world. At other times the full moon rises clear and beautiful, flooding the valleys with silvery light, while the darkness of the cañons is so in. tensified that they can be traced for miles. The valley becomes a world of shadows, and weird shapes form and re-form, advance and retreat, as the moon rises and floods the land with light.

The mountains are not always peaceful. At times they are rent by fierce northers, when pandemonium seems to have broken loose, and the scene is made more terrible by the fact that it is blowing in a cloudless sky. Such a night was clear and brilliant; the stars, due perhaps to the electrical condition of the atmosphere, took 
on a more brilliant glow and blazed like electric lights. The trees in the upper ranges bent and bowed before the blast, branches were beaten to the ground, and occasionally the crash of limb or trunk came down the wind, or the roar of some avalanche of gravel where the rain had loosened the soil, and sent it crashing down the mountainside. Reaching its climax with roar and wild acclaim, the wind suddenly ceased, to come on again with renewed force. Such winds are the most dangerous and blow in a clear sky without rain; they come in over the ranges from the north, sweep in through the passes, as the Cajon, and in the form of sand-storms fill certain sections with dust that is carried miles out to sea, where I have seen it coming on, a vast, ominous deep-red cloud.

The rain-storms in the mountains fill the streams with melody and the forest thrills with ten thousand vibrant notes. The roar and cadence of the greater falls, the ripple over rocky beds, the wild sweep and surge of rain or sheets of water against granite cliffs, and the wail of the wind as it rises and gives rein to its fancy, sweeping over the ridges, rushing down into the cañons, through the chaparral, on in sheets and rivers, bending great trees and snapping off the dead wood, are all features in the splendid setting of the forest stage.

By such a storm I was isolated in the mountains for several days; the ordinarily peaceful streams became violent rivers; Millard Cañon, the Arroyo Seco, and Negro Cañon were impassable, and at its height I 
expected that our cabin would blow over into the cañon, and suggested to the owner that it would not be a bad plan to rope it down to a neighbouring tree. As it did blow over in a later gale it was evident that my halfjoking request was not unwarranted. It had rained heavily and steadily for three days; the wind came in a series of gusts, and when they passed and went whirling up the cañons, the silence was profound by contrast; but it only made audible another roar. At first I thought it the rush of waters in the cañons; but it had so weird and ponderous a note that I went out and made my way to the cañon's edge on the north and found that it was caused by the rolling of big rocks down the steep bed of the cañon. So strong was the flow of waters, that the rounded and polished boulders began to move and came rolling down the bed of the stream, creating a vibration that filled the air with weird and ominous sounds.

On the fourth day provisions gave out and a volunteer was sent down, but the stream caught his horse and swept it away. The following day the clouds melted, the sun broke through and filled the valley, caressing the mountains with its rays, and a week later the face of the land had changed to lighter and warmer tints.

Once in a fierce storm in the mountains I faced from a divide a fall on the distant slope. At ordinary times it was a slender line of silver, a cord of the mountain lute, but now every cañon, every lateral branch, was running full and the fall was a splendid thing-strong and resonant. As I crouched in the saddle in the 


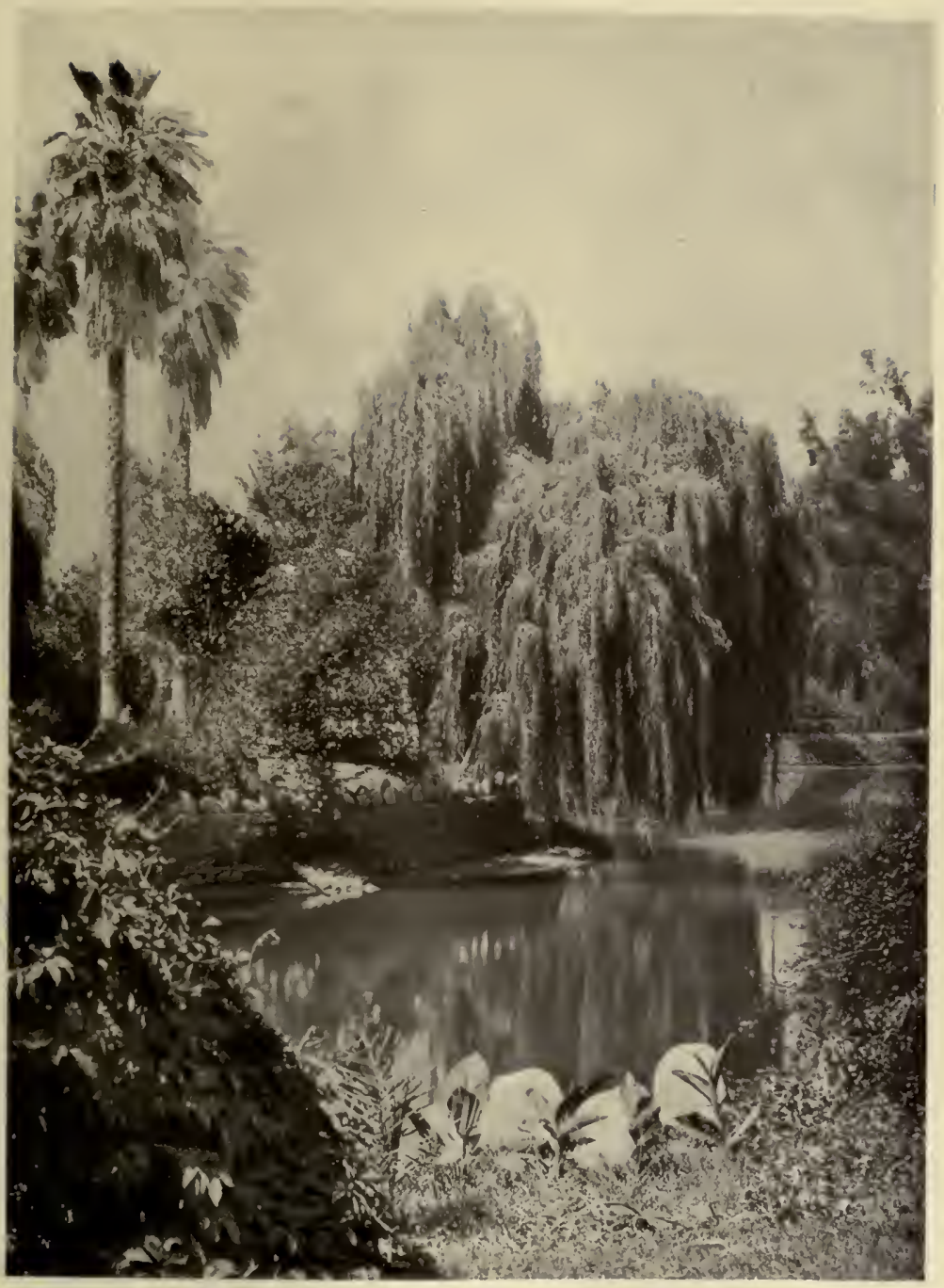

Palms at Santa Anita Ranch, Arcadia, San Gabriel Valley. 

friendly shelter of a big rock, I saw the fierce gusts of wind strike the falling water, lift it from its course, toss it in air like hair, whirling the strands so high that for a moment they seemed lost; then as the wind passed on they took shape and form again. Then the storm would gather its forces and sweep into the rocky and polished bowl worn away by time and eternity, and swing the silvery mass like a gigantic pendulum, from side to side, tossing it here and there as though in play, to creep away and go roaring on through the forest, up the slopes, raging into lateral cañons, until I could no longer hear it and only trace it by the bending trees silhouetted against the leaden sky on the edge of the range.

The southern mountains have not the vast and extended forests that symbolise the Yosemite region, but they have a wealth of trees in the mountain laurel, buckthorn, lilac, the wild cherry, madróna, manzanita, pines of several kinds, false hemlock, white cedar, juniper, oaks, and many more.

All the cañons are filled with verdure; each is a park, with all the glories of ferns and wild lilies and a host of flowers that lure the stroller on and on into the maze of gulfs and rivers of green which make up the forests of the Sierra Madre.

He who views the mountains from the valley fails to appreciate their size; the wall of bare rock is perhaps disappointing, but here is a range whose exact prototype does not exist in any land - austere, 
burnt out in places, gaunt and grim, it symbolises the war of eternal ages. Mother Mountains indeed, well named by some mountain lover, as all mountains are the mothers of the land at their feet, and Southern California is the child of its ranges, and the fertile valleys are the washings of its deepest cañons and loftiest slopes.

Here is range after range as high as Mount Washington. The Adirondacks, Alleghanies, and all the peaks of New England could be thrown into the maze of cañons of this range, and the addition not be suspected. No mountains in America rise so abruptly from their base, none present such an array of deep cañons and precipitous slopes, such long and narrow divides, such stupendous reaches from summit to valley. I am familiar with many mountain ranges, but do not recall any such wall, or sudden rise, as that which confronts the pilgrim from the East as he crosses the Colorado or the Mojave desert and ascends to the California divide. He stops near Salton, where at the deepest point the valley is two hundred and eighty feet below the level of the sea, and climbs to the divide nearly a mile above it amid stupendous peaks which tower from ten to eleven thousand feet in air, the heart of the Sierra Madre.

In strolling through the cañons or on the upland mesas you obtain a glimpse of the life. There are countless birds; you may see the California condor, as I have in the oak forests of the San Gabriel. The 


\section{Life in the Sierra Marde}

ordinary buzzard soars over the cañons, and the roadrunner, or paisáno, garbed in splendid colours, runs along the trail. In the open, the ground-squirrel lives in burrows, uttering a peculiar cry, "spink, spink," resembling the blow of a blaster boring a hole in hard granite. You may occasionally see a badger, and countless little blue-throated lizards bask on the rocks, while beneath them you find one with a turquoise-blue tail.

Southern California is remarkable for its freedom from disagreeable animals. In my travels I have never encountered an adult rattlesnake, though they are here, and rarely have I seen snakes of any kind, except the gopher snake. Tarantulas and scorpions are indigenous to the soil, but are rarely seen. The horned toad is the common lizard, harmless, and an interesting pet. The variety of birds is endless, and the chorus of song: about the homes at sunrise in early spring is one of the charming features of a remarkable country. 



\section{Orizaba \\ On the Slopes}





\section{Chapter XV}

\section{The Wild Goat on Orizaba}

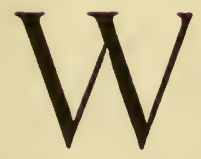

HEN Cabrillo came up the California coast in 1542 , he sighted a large island with two prominent peaks, and from almost anywhere in the mountains of Southern California they can be seen rising from the sea.

Cabrillo named the island, after one of his ships, La Vittoria, but the name given it by Viscaino, in 1645 , Santa Catalina, from the saint's day of his arrival, has held down through the years. One of the peaks is called Orizaba, and the other Black Jack. They are not high; though from a distance they might be considered in the five-thousand-foot class, twenty-two hundred would be nearer the truth; yet Orizaba and Black Jack have summits and slopes that in steepness might belong to the top of some wind-swept peak ten thousand feet in air. I say this, as I have been to the peaks of both mountains on horseback, and, with some knowledge of trails in California, never found myself in quite so disagreeable a position as one afternoon when trying to 
lead my horse down the south side of Orizaba, sliding just ahead and trying to keep from under him. I had unadvisedly left the trail, and was trying to reach a goat, when I found myself in a maze of fallen rock that had been breaking off and rolling down the slide for ages. Nevertheless, I commend the mountains by the proper trail to the lover of mountain climbing and hunting, as, should the goat elude him, he will bag one of the most attractive and enduring views in all Southern California.

The mountains rise very nearly in the centre of the island, and from any point present the appearance of great volcanoes, surrounded by lava-like rocks, yet all about rise hills covered with chaparral, and verdant rivers wind away here, there, and everywhere. My starting-point had been a camp at Middle Ranch, that lies under some cottonwoods at the base of the Cabrillo Mountains, where they form the north slope of the cañon. It was the dead of winter, and the island was carpeted with alfileria, wild grasses, and clover. The cañon stream ran merrily on, coming from some mysterious place and gaining in volume, rushing in beneath arcades of cottonwoods, willows, and alders, whose tops were often draped with masses of wild clematis, and so reaching the sea, at a little beach on the south coast two or three miles down the cañon, up which the strong west wind came, bearing the sound of breaking waves, and the soothing melody of the sea.

The wild goat was said to be in force at or near the head of Cottonwood Cañon; so, with rifle-scabbards fast- 


\section{The Wild Goat on Orizaba}

ened to the big Mexican saddles, we rode across the hills to the north, and gradually rose, entering the chaparral, coming out on the edge of a wood-lined cliff covered with ironwood, manzanita, and scrub oak, while over all the slopes, blazing in deep reds, were Heteromeles, or "holly" berries, that are in a way as famous in Southern California as the cherry blossoms of Japan. A deep cañon swept up to the right, partly filled with cactus and chaparral, and opposite rose Orizaba. As we stood, taking in its beauties, the bleat of a wild goat came on the air, and soon after a herd was seen winding around the slope, then turning slowly up a trail. I never made a better miss in my life, putting a bullet from the saddle four or five feet this side of the big buck in the lead and sending the herd up the slope on a run, where they looked like small dogs, so far away were they.

We soon found the trail, a precipitous plunge down through the chaparral, frightening scores of valley quail, coming out into the cañon with its patches of cactus, then turned up the slope, finally reaching another trail which led up the rocky side of the mountain, a goat and sheep trail, over which the wiry horses slowly made their way, by adopting the zigzag method, literally beating up the slope in short tacks, I leading my animal, my comrade riding. The trail was like one, described by some wag, that led into a tree, and for an hour we worked our way up the side of the almost impassable mountain, gradually rising above the hills and cañons.

Finally, reaching the summit, we fastened the tired 
horses to the rocks and crept slowly over the rough surface, and then, out on a mass of seeming lava, three hundred yards away, saw the herd, a large buck standing out in bold relief. I had disgraced myself, so insisted that my companion take the shot, which he did; but whether it was the strong wind or the peculiar pulsating atmosphere, he missed, and the animals plunged down the side and disappeared. We followed, and reaching the spot, heard them somewhere far down the slope, so returned for our horses, stopping for a few moments to take in the splendid vista that stretched away. We could see the ocean on all sides, an ineffable tint of old Persian turquoise, and below and all about cañons, peaks, and ranges that formed the most remarkable jumble and maze it was ever my good fortune to look down upon.

The island was an emerald in a setting of azure, its green intense-the green some of the French realists paint,- - and on this background the cañons were darker, melting one into the other. Opposite were the Cabrillo Mountains and Middle Ranch Cañon, and to the west the hills went tumbling away to the sea, to meet it in lofty rocky cliffs, against which a light-blue haze seemed to play. To the east rose the snow-capped mountains of the Sierra Madre, San Antonio, San Jacinto, and San Bernardino, ten and twelve thousand feet high; their white summits standing out against the blue sky in strong relief, across thirty miles of the blue Pacific and as many more of green hills and vales. All Southern 


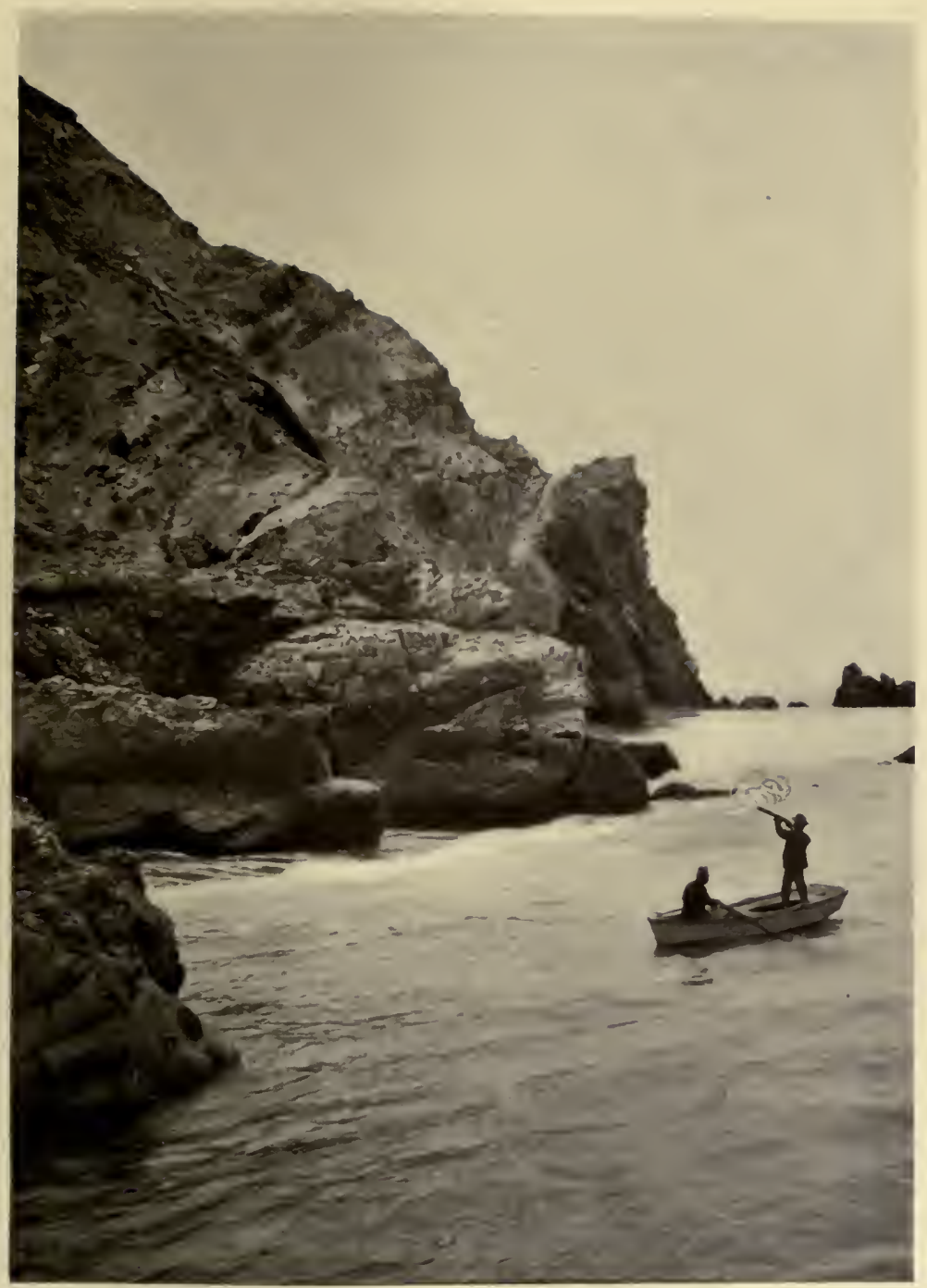

Wild Goat Shooting from a Boat, Santa Catalina. 



\section{The Wild Goat on Orizaba}

California was before us and the islands of the sea.

Perhaps you have led a horse down the rocky slope of a mountain where the trail is a matter of fiction, a trail by courtesy, where the horse slides and you are continually stepping aside to allow him to pass, then rounding him up by the riata which you have fastened about his neck to anchor him by. If so you know its difficulties and delights. Half-way down we came to the end of navigation on a bed of broken rock, and it was by a special dispensation that we got out and down, the dispensation being clever horses.

We followed up the cañon to its head, climbed Black Jack, and on the way up got the shot that gave us the big head as a trophy, shooting the goat across the gulch by mere good fortune. It was two o'clock that afternoon when we secured the game and started home down the cañon, after a series of seemingly endless climbs, taking six hours to secure one pair of horns.

Hunting the wild goat is not always so difficult. I have run upon them in the lowlands, and there are places well known to Mexican Joe and Joe Adargo, the guides, where they can be had with less difficulty. But I believe the sportsman will not care for the easy places, as the climb over these mountains, the wildness of the scenery from the summits, the beauty of the cañons and their verdure, will well repay the effort. A fine hunting-ground is that on the south-west side of the island, where it rises and faces the sea in cliffs often so precipitous that even the wild goat cannot crawl down. 
Riding out on some of these points the cliffs for miles can be seen. A fine road extends the entire length of the island from Pebble Beach to Avalon, from Avalon to the Isthmus at Cabrillo, and then on for five or six miles, any part of which will repay the lover of nature.

The following day we took the trail up Cottonwood Cañon, visiting an ancient stone cave dwelling on the divide, a great spur of Orizaba, where the ancient Santa Catalinans lived centuries ago. At the entrance a huge clump of cactus grew over piles of gleaming abalone shells, which the natives had carried up the long hill from the sea several miles distant. On the way up the cañon we found traces of ancient occupation,-bowls or mortars partly worked out in the solid steatite, or stone implements; and at night rode into camp at Empire, where verd-antique is being quarried. This ledge is an ancient olla manufactory, and the marks and scars of the work are still to be seen. Here all the bowls or mortars of soapstone found in the graves of the Southern Californian Indians were made, shipped over the Santa Catalina Channel in canoes, and exchanged for deer skins and other products.

The next morning we started for Avalon by the north coast, following a narrow trail skirting Black Jack, now along cliffs so precipitous that a misstep would send the horse rolling down a thousand feet into the deep cañons, always on the coast, until the head of the trail was reached, where we followed the windings of 


\section{The Wild Goat on Orizaba}

the cañons in and out until we entered the vale of Avalon. I commend this ride on horseback to the hunter who enjoys wild and picturesque situations in mountain and cliff climbing.

I have hunted the wild goat in boats, the boatman rowing along shore, the animals being found high up on the face of cliffs, and I have often seen them between Pebble Beach and Seal Rocks, where the island shores rise in splendid cliffs. Thousands pass this front, this fortress of rocks, in the course of the year, but it is only when some man is stranded on the beach and cannot climb the cliff, and so reach the town of Avalon, a few miles away, that one realises how impossible it is. I have seen a goat come down the face of this precipice several hundred feet high and find itself unable to get back. It is possible to climb it in places, but the human climber is then often confronted with a series of steep cañons that are menacing and dangerous to a novice.

The wild goat of Santa Catalina is the common goat grown wild, which some one placed upon the island years ago. It has multiplied so that several thousand are to be found, affording excellent sport; at least I have always had to earn my game in long climbs that well repaid the exertion, if not in game, in the experience and a certain charm of isolation.

The wild goat has developed certain peculiarities: the horns are often larger, and the bucks sometimes have a heavy development of hair over the chest not seen in the tame goat. The kids are excellent eating, 
especially when barbecued by some of the Mexican past-masters of the art on the island.

On one trip to Middle Ranch, the barbecue was held in the evening around a big camp-fire. The Mexicans had stripped off long poles of willow, and impaling big joints of meat, held it over the coals, turning it around and around until done to a turn; then there were chili con carne and chili colorado and frijoles, and then, over the cigars and pipes, tales of the old times, by the oldtimers, tales of the days when Santa Catalina, according to legend, was traded for a horse.

Middle Ranch Cañon, which almost cuts the island in two, is remarkable for its climate. In summer a cool breeze sweeps in from the sea, coming up the long winding river of verdure, making the conditions almost perfect; indeed the climate of Santa Catalina Island is worthy a treatise by itself, so peculiar is it, so perfect from the insular standpoint.

Hunting is what it is made. One may coop a jackrabbit in a large corral and watch greyhounds run it down, and imagine it sport ; so, too, the hunter may at times corral the goat of Santa Catalina in some corner and slay it without trouble with the aid of a guide, who is also seeking minimum physical exertion; but the hunter who will go out into the open and climb the crags of the big mountains or peaks will, I venture to say, in the majority of instances, have hunting and climbing that would be considered all-sufficient if for "wild goat" had been substituted the term "bighorn,"- "What's in a 


\section{The Wild Goat on Orizaba}

name?" Some of the heads that are brought into Avalon by goat hunters are remarkable for their spread of horn, and there are several patriarchs that have for years defied hunters of high and low degree.

In riding over the island after wild goats or quail, one occasionally sees foxes, while the whir of the valley quail fills the air at times. For years there was a herd of mysterious burros that had run wild and defied capture. This may seem incredible, but those familiar with the gentle burro of the mainland have little or no idea of the speed attained by the same animal when he returns to nature.

I once rode upon these animals on the west side of the island, and, mounted on a good horse, made the attempt to catch them. There were three, one taller than the others. They stood and looked at me for a moment, the next we were in a whirlwind race over a bad country strewn with rocks. I certainly gained on them, but I was surprised to see how long it took. In the end I ran the burros down, and could possibly have roped one, when they dashed headlong down a steep cañon and disappeared, relieving me of the embarrassment.

To see this interesting island with its rare flora, in some instances unique, its wealth of archæological lore, its wild and attractive scenery, one should become a goat hunter, take a man like Mexican Joe, the oldest guide and inhabitant, who knows the island thoroughly, a good saddle horse, and a single burro, and make the trip from one end to the other, sleeping in the open. 
Two weeks or more can be spent in this camping trip; typifying the attractive life in the open on the Channel Islands. 


\section{The Rise of \\ DonAntonio}

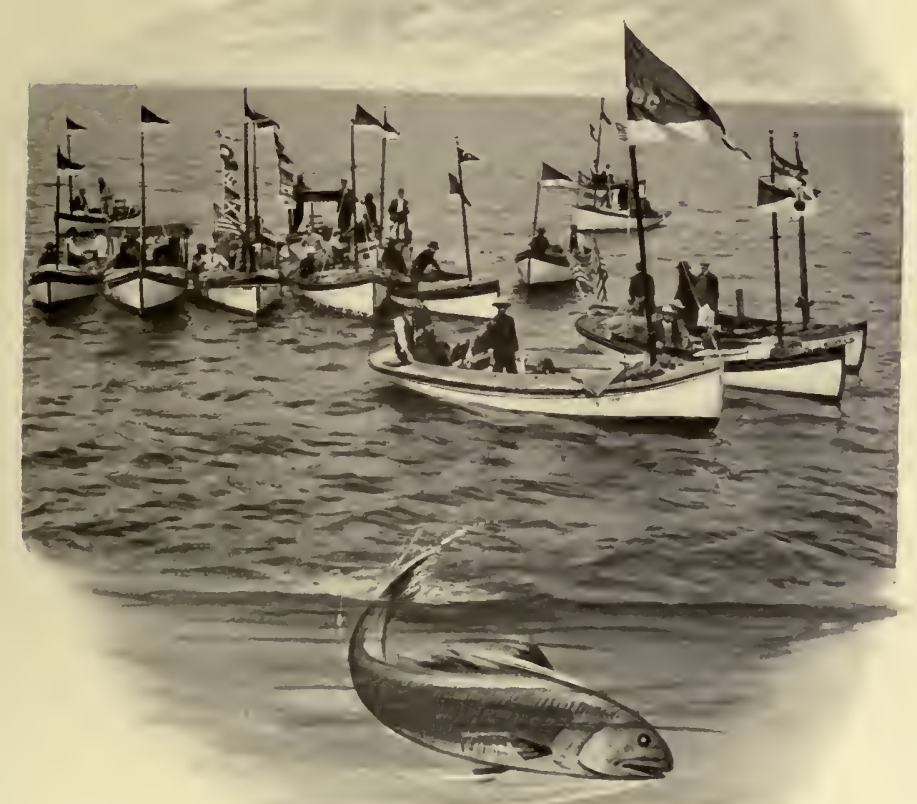





\section{Chapter XVI}

\section{The Rise of Don Antonio}

X ITH few exceptions the coast of Pacific $^{\text {ITH }}$ North and South America is protected by a fringe of peculiar seaweed known as kelp, a long, rich, olive-green marine laminarian vine which rises from the bottom to the surface, in thirty or forty feet or more of water, and droops or hangs in festoons, forming a beautiful floating garden with a life peculiarly its own. On the rocky islands of the Pacific Coast from San Clemente to the Farallones this vine is particularly abundant, and on the lee shores it may be examined with ease from the glass-bottom boat.

At mid-day, at half tide, is the best time to visit these hanging gardens of the sea; then the bottom can be seen plainly, the water a vivid turquoise blue, gleaming brightly through the interstices of golden branches, which, when illumined by the sun, take on hues of old gold and amber. The leaves are twenty or thirty feet in length, about twelve inches in width, richly fluted, and hang in a thousand positions of grace and beauty, 
so that in peering down from above one looks through innumerable halls, arcades, and parterres that extend away to infinity.

In South America, especially about the Falkland Islands, the kelp (Macrocystis) attains encrmous proportions, sections estimated at one thousand feet in length having been taken up and used as anchors for vessels, which thus were saved the trouble of lowering and hoisting anchor. On this desolate coast the kelp forms a protecting fringe for fishes which otherwise would be unable to exist, owing to the constant and heavy surf that is always piling in, and thus incidentally the miserable Fuegians are saved from starving, subsisting almost entirely upon the fish, the barren, half-frozen land producing little or nothing. Everywhere along-shore this forest of hanging vines constitutes shelter for many animals. It is a forest of seaweed rising from great depth, rolling over and over in strange but graceful convolutions in the surf or tidal currents, a menace to swimmers and often to vessels.

Along the California coast at extreme low tide the kelp lies in such thick masses that it forms an almost impassable barrier; so much so that once in making a port we found it almost impossible to force a sixty-ton power yacht through it. The entrance of the harbour was made ultimately by stationing a man on the bowsprit to pass the word how the helmsman should steer to avoid the enormous leaves that, in tangled masses, blocked the way. These huge vines do not indicate a 


\section{The Rise of Don Antonio}

rocky coast, but fasten themselves to small stones anywhere in water of medium depth from a few yards to half a mile from shore, and when thrown up show the short roots coiled about small objects with a vise-like grip.

These hanging gardens of the sea afford a home for a multitude of strange animals, which have a singular protection - that of mimicking the tone or colour of the leaf. These animals include crabs, shell-less mollusks, and fishes. One of the crabs, which is nearly two inches across, is so perfect an imitation of the kelp that when lying directly before the eye, it is difficult to see, unless it moves. It has peculiar points and spikes which further intensify the resemblance. Lying on the great leaves are numbers of slug-like creatures, "shells" without shells, tinted a rich green, safe in this protection from nearly all intruders.

But the most remarkable resemblance is seen in a fish called the kelp-fish. It is about a foot in length, of the exact colour of the kelp, with a long continuous dorsal fin frilled exactly like the edge of the leaf. Did this fish dart about or comport itself as other fishes, it would be observed at once, but it does nothing of the kind ; it lies at the bottom or near it, standing literally upon its head, with its tail extending upward, with the shorter kelp leaves, and in this position, hanging in the gardens, waves to and fro with every surge that sways the ocean forest. I have looked for these fishes for a long time, watching every leaf, and finally found that the elusive 
creature had been under my eye all the time, but had escaped careful scrutiny. I have examined dozens of them through a water-box or glass-bottom boat, and in every instance they were holding themselves in some peculiar position which made it almost impossible to distinguish them from the green masses of weed that folded and unfolded in the mysterious currents.

In calm weather the kelp leaves lie dormant like sea serpents upon the surface, unfolding and folding listlessly; but when the wind rises and the sea comes in, it appears to be filled with waving monsters that, gripped in fierce embrace, are rolling over and over.

The waves are coloured a deep golden-brown hue by them ; they fairly fill the water, and coil and re-coil in a manner particularly dangerous to an unfortunate swimmer thrown among them at such a time. Often in fierce gales the entire kelpian growth of a locality will be wrenched out and cast ashore to form a pile or windrow for miles along the beach; but in a marvellously short time the kelp again appears in luxuriant growth.

These gardens of the sea have proved so interesting that a so-called glass-bottom boat has been invented at Avalon, Santa Catalina, where a fleet is in daily operation. Almost every visitor to the island goes out to drift over the floating gardens of the sea and gaze down through the big glass window at the strange animals of the kelp. Among the fishes is a giant bass six or seven feet in length, which occasionally swims across the window-which recalls to some anglers along the 


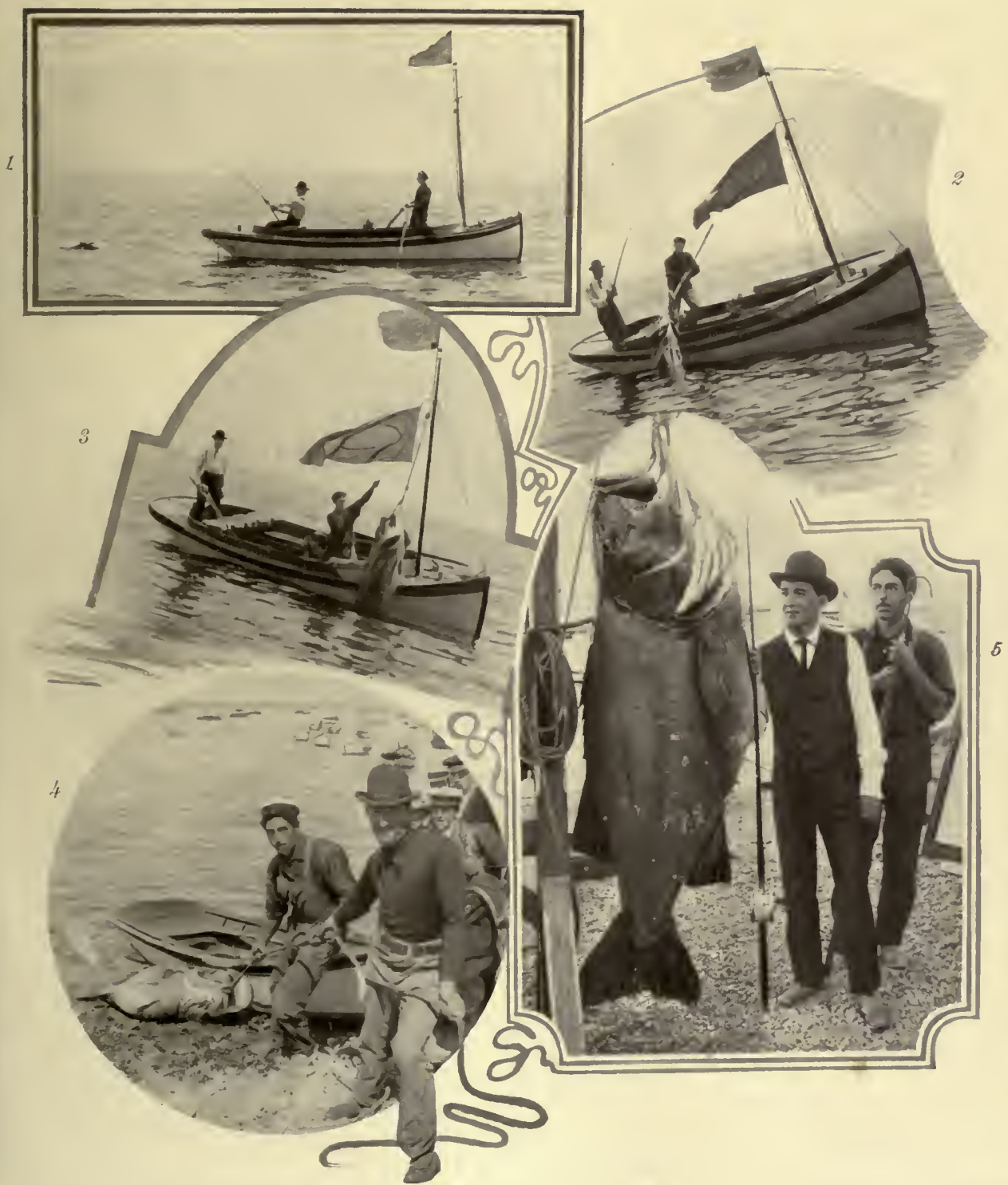

Catch of a Black Sea-Bass with Rod and Reel by Ernest Follon. George Johnson, gaffer. Santa Catalina.

(1) Playing the fish. (2) Gaffing. (3) Hoisting the 35o-pounder aboard. (4) Hauling the bass to the scales. (5) The proud moment. 



\section{The Rise of Don Antonio}

channel the incident of one Tony Oromo, now the captain and proud owner of a glass-bottom boat.

He was a very superior person, this "Don" Antonio Oromo, and interest in him was accentuated by certain legendary wraiths, possibly of the imagination, that drifted in and out, and were common talk about the gaily decorated boat-stands of Santa Catalina. Don Antonio certainly never claimed to be a descendant of Montezuma, or that his ancestor was a great captain of Viscaino's fleet, which visited the island in 1602 ; in fact, nothing could be traced to him except a statement that his grandfather once owned the island and traded the property, now worth millions, for a white horse; why white no one knew. I had fished with him, as the guest of a friend, on divers occasions, and the only words he uttered were, "Si, señor," in a mellifluous voice, in response to the stern demand for more "chum," when possibly he had fallen asleep. Yet despite this, Don Antonio had "an ancestral reputation," which a certain manner, suggestive of romance, lent colour to. No one had ever heard of him as a boatman or fisherman until my friend discovered him; indeed, a Mexican rival in the gaffing line, of no particular ancestry, laughed loud and long when he learned that "Tony" was going to row during the tuna season.

"What, him!" said Nicola. "He never see a gaff in he life. He fish? Why, he don' know a tuna from a skip-jack. He mak' me tired, he do, there's a fac'. 
Tony rowin'? Eh! who say he 's a Don? He better be up Middle Ranch grubbin' cactus; there's wha' he b'long."

Don Antonio must have heard these and other criticisms, but he said nothing, and whether deep in his Aztec heart he was determining to give back these taunts, blow for blow, no one could tell; but the fact remains that he was another example of what opportunity will do for latent genius. He was born to fame, and at the end of the season, not long after the midsummer solstice, still silent and imperturbable, he stood a prominent figure in one of the greatest feats in the world of angling, overshadowing and silencing all his critics among the boatmen, gaffers, and chummers of the island.

It came about as follows: The tuna season at the island closes for some mysterious reason on or about August first, though specimens have been reluctantly caught in the middle of that month, and their high and lofty tumbling may be often witnessed far into the fall. The ending of this season of muscular conclusions with the greatest of game fishes finds a small army of expert anglers, who delight in the excitement of this big game, with summer but partly gone and the tuna retired from the field, its season being May, June, and July. It is now that the resources of nature, so far as they relate to big game at the Southern California islands, become apparent, and instead of putting away the split bamboo and green-heart rods and big tuna reels, the angler, 


\section{The Rise of Don Antonio}

who perhaps wears the blue button of the Tuna Club, turns to the black sea-bass, that giant of the tribe, that is peculiar to the Kuroshiwo, where it flows by the kelp-lined shores of Southern California. A fierce war has always raged in the vale of Avalon, where it opens into the summer sea, over the respective qualities of this bass, ponderous enough to be the Atlas of the fishes and

Sustain the spacious heavens

of the sea.

A few choice spirits, doughty knights of the rodand I will not gainsay their skill and prowess,--bear the standard of this fish on their escutcheons and claim that it is the hardest-fighting game of these waters, the superior of the tuna or any of the great conquistadores of the angling arena. In the Tuna Club they have their black sea-bass cups, on which their winning names and the ponderous weights of their catches are engraved; their linked gold badges, worn proudly at annual banquets; and, like all minorities, they claim the world as theirs. As each season larger fishes in both classes-tuna and black sea-bass-are caught, the tension becomes more acute. The boatmen side with their employers, and so, by virtue of his patron, Don Antonio became an advocate of his big bass, and in his way fought its battles with the tuna gaffers, and bore their gibes and scorn with easy philosophy. "Los paises del sol dilatan et alma," he once retorted to his disputant, 
whereby Don Antonio implied that those born in this land of the sun-down sea, as Joaquin Miller has it, have so much expansion of the soul that such things do not worry them; and so he met the knights of the tuna, held his peace, and blew the blue smoke of his cigarettes out over the vermilion-tinted waters of Avalon.

If one were to take a small-mouthed black bass, build it up until it was six feet long, and stuff it until it weighed anywhere from two hundred to five hundred pounds, some conception of the appearance of the black sea-bass (Stereolepis gigas) of Santa Catalina might be formed. It is nearly a perfect bass in form and feature. Its eyes are blue; its upper surface tinted old mahogany, and its under surface gray - a mighty creature of solemn mien.

Deep in a cavern dwells the drowsy god, Whose gloomy mansion nor the rising sun Nor setting visits, nor the lightsome moon; But lazy vapours round the region fly, Perpetual twilight, and a doubtful sky.

Ovid might well have had the great bass in mind when descanting upon the home of the god of sleep, as while the tuna frequents the high sea, now blazing its way into the sunlight, the black sea-bass lives in the canopied forests of kelp, whose long leaves form caves and retreats of fantastic shape, ever changing with the current that sweeps along the rocky coast in whimsical and erratic measure.

It has been my fortune to take many of these fishes 


\section{The Rise of Don Antonio}

weighing from one hundred to three hundred and fifty pounds, with a hand-line, to have lost many with the rod, and once to have been fairly beaten in a short-rod trial of twenty-two minutes. Taking the fish on the hand-line (though I would not be understood as commending it) is not without its excitement, as my capture of a three hundred and forty-seven pound specimen off the rocks may illustrate. We rowed around the south end of the island, passing the long Pebble Beach, by the sea-lion rookery, whose inmates stared at us lazily, roaring and barking hoarsely, by the Sphinx's head that gazes eternally into the west, where

\section{Tempestuous Corus rears his dreadful head,}

then turned to the north-west and, over the long groundswells, moved up the island to the restless kelp beds, the home of the bass. The shore here is precipitous and wild, beaten by the winds of centuries, and coloured with all the tints that mark the sunsets of this isle of summer. There is no shore line in rough weather; the pitiless sea piles in, buffeting the very base of the mountains, and is tossed high in the air in white flocculent masses amid the booming and crash of contact with seen and unseen rocks.

Directly back of Avalon, a half-mile offshore, in sixty or seventy feet of water, lies a vast submarine forest of kelp, for which the bass invariably make when hooked inshore. Within one hundred feet of the beach is another kelp bed, whose leaves lie along the surface 
and repel the waves, the feeding and spawning ground of the bass. In one of the little bays formed by the kelp we anchored, hauling aboard one of the great leaves for the purpose, which could be tossed over at short notice. It is a sport in which the angler must at times let patience possess his soul, and I have sat for hours feeling the throbbing line without a strike; but this is the exception. Our line, baited with a sevenpound whitefish, was tossed over and allowed to sink within four feet of the bottom, and with a turn about the rowlock we waited, fishing betimes for sheepshead with the rod, a gamy creature ranging up to fifteen pounds.

So engrossed were we in this sport, taking the big red- and black-banded fellows as fast as they could be fairly and honestly played, that the object of our trip was all but forgotten. But suddenly the sheepshead ceased biting, there was an ominous pause; it was either sharks or bass, but which? I reeled in my line and took the bass line in hand. The current running to the south played upon the line with a gentle musical rhythm. Now a marvellous jellyfish fouled it, and was rent asunder, or a mysterious olive-green kelp frond swept along like a living thing, its dim shape faintly outlined against the blue.

The ocean was as smooth as glass, the wind gods were resting, and the only break on the clear surface were the fins of yellowtail, that glistened in the sunlight as they patrolled the kelp, or the fairy sails of the 


\section{The Rise of Don Antonio}

silver and blue velella as it rose and fell, an idle ship on a windless sea. Suddenly I felt the line tauten, as though the coming flood had increased in intensity. How it thrilled and imparted to the nerves a tingling sensation! Greater and greater came the tension. I dropped over the anchor of kelp and paid out a foot of line, then two, very slowly, gradually increasing until it was gliding rapidly over the side. The boat, that by actual test weighed but 125 pounds, whirled gently around; then, having given the unknown ten feet of line, I stood up and struck home. Down on my knees, almost overboard I went, jerked by the fierce response, and through my unyielding hands hissed the line, churning and cutting the water, slicing it into great crystal sheets.

I had the coil amidships, and it fairly leaped into the air as the fish made its rush, twenty, fifty, one hundred feet. I seized it and braced back. Nearly elbow deep went my arms in the water; down went the boat, my companion sliding into the bow to offset it ; down until the water was dancing at the rail; down until the man in the bow seemed to be up in the air; down so deep that my face was so near the surface that I could hear the mysterious crackling sound against the keel. I was about to give way to this doughty plunger when he turned. I sprang to my feet and took in the line. In a great circle he surged around the boat, and I gained by desperate hauling, not moving the fish, but pulling the light boat to him, in this way making thirty or forty 
feet. Then, without warning, he jerked me to my knees again, and with steady lunges strove to take the boat under water, and I was content to give, inch by inch, foot by foot, until he calmed down.

The bass was now headed for the offshore kelp bed, half a mile away, towing the boat so rapidly that the foam rose under the stern in an ominous wave. The secret in this fishing is to fight the game continually, for, does the man at the line rest, the bass recovers in an equal ratio and the contest may be kept up until the bass reaches some retreat offshore and plunges into the kelp, breaking the line. To prevent this I played it constantly, hauling when I could, and slacking only to prevent foundering; now flat on the bottom, bracing to withstand a desperate rush; now taking in the line, receiving savage blows, never stopping, until, fifteen minutes from the time of the strike, I saw a gigantic black and gray form coming slowly out of the blue. When the fish saw me it plunged down in a vicious rush, but I turned it up again, and by strenuous effort brought it near the stern. The boat was so small and light that my companion lay in the bottom to preserve the equilibrium, and I attempted to gaff the monster by holding the line in my left hand, gaffing it amid a terrific flurry. Once the iron in, it was jerked from my hand repeatedly, and I nearly followed it overboard. For half an hour I manœuvred, and every time the fish was brought within five feet it either plunged down or rushed around in a manner that boded ill for our safety ; 


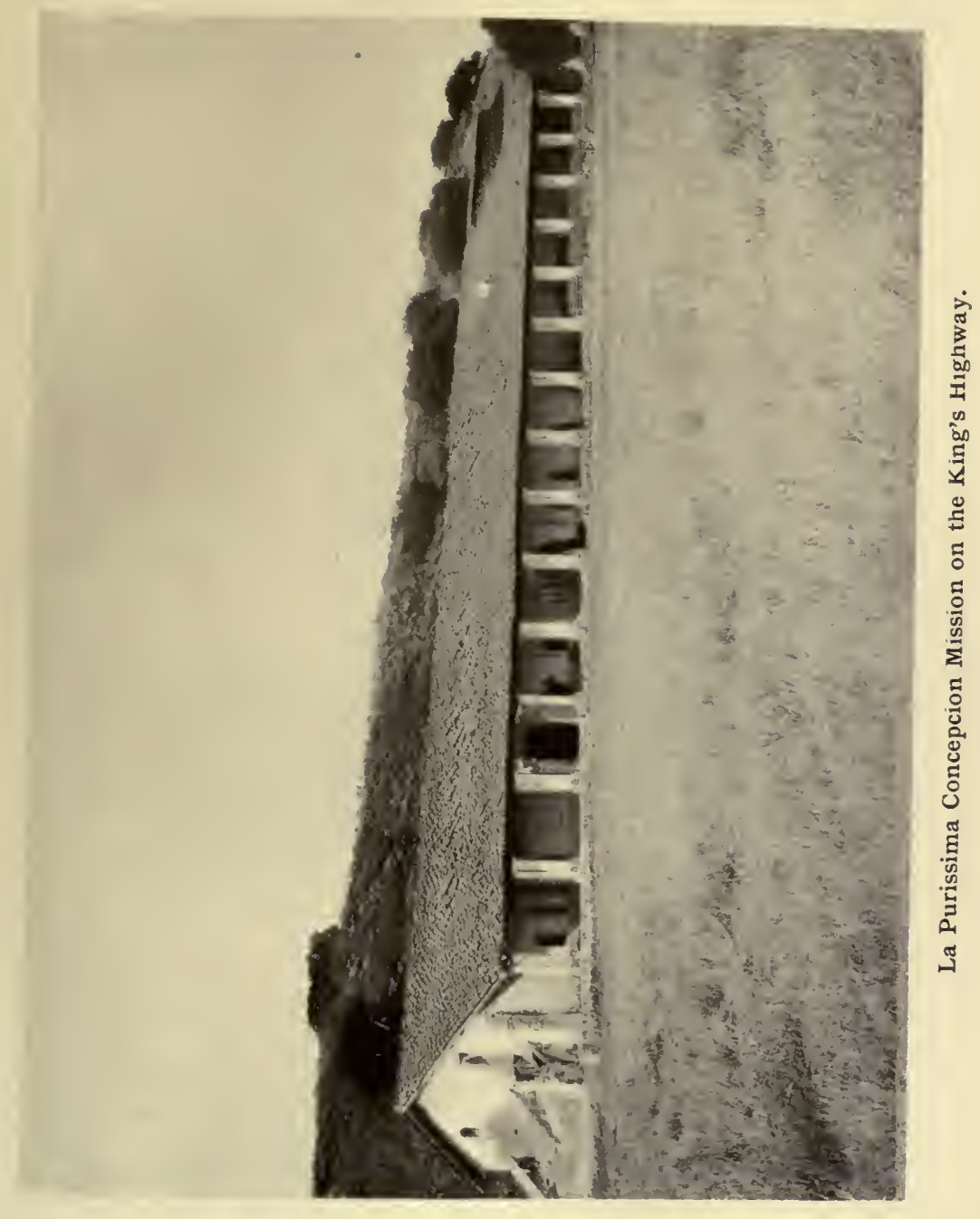





\section{The Rise of Don Antonio}

indeed, twice the boat almost foundered. The wind was now blowing fresh from the north-west, and the sea had picked up in a surprising fashion, adding to the difficulty; but the bass was brought alongside, and after many efforts a rope was passed through its gills and mouth and lashed. Then we sat back to breathe and eye the rising sea. The boat, instead of rising on the swell, was held down by the fish, and it was evident that a breaker might sink her.

It was impossible to get the fish aboard, and to tow it around Church Rock, where there was a heavy sea, seemed inviting disaster; but we attempted it, and after running the gauntlet of the Sphinx, in an hour's pull, had the fish in smooth water. Five miles we towed it, finally meeting some fishermen, whom we hired to aid us in hauling the fish aboard. It almost filled the boat, and I sat on my game while my companion rowed. But we were so low in the water that the least sea would have foundered us, so we engaged the men to convoy us in, and finally entered Avalon Bay masters of the situation.

Similar experiences characterised other catches, and induced the belief that the big bass could be caught with a rod. It remained for General Charles Viele to demonstrate that this could be accomplished. I accompanied him to the same locality one morning, anchoring undoubtedly over a school of fish, as they bit fast and furious. The launch was anchored inshore, and the General opened the campaign by casting from the 
small boat alongside. The moment he hooked the fish the boatman pushed off and rowed after the game, adopting the method so successful in tuna fishing. The bass took him one hundred yards or so to sea in the first run. In the meantime I had cast from the launch, and hardly had the bait reached the bottom before my reel began what proved a requiem for lost tackle. I was firmly anchored, and the bass took my line and tip; then more line and two tips, and after I had hooked four fish and used up my rods, demonstrating that I could not stop them from an anchored launch, I threw over a handline and presently landed a bass of Ioo pounds; then one of 248 pounds, the latter with the aid of the General, who, singularly enough, left his fish after two hours' fight and came aboard for lunch and reinforcement. The bass had towed the boat about, giving them a battle royal, and had finally reached kelp and fouled, but it was still hooked. The line was tautened and the rod lashed to a tin oil-can and left floating. Later a grapnel was successfully used to tear away the kelp, and in half an hour the bass was gaffed, and with two other large fish we steamed for port. The General's bass weighed 227 pounds, while my handline catches weighed respectively roo and 248 pounds. I had timed him at the strike, and he brought his fish to gaff in two hours and thirty-eight minutes.

This was in I894. Then came the catch of Mr. S. M. Beard, of New York, who took several large fish with rod and reel, and finally that of Mr. F. V. Rider, 
formerly of New York, now of Pasadena, who in 1898 startled the angling world by landing in fifty-five minutes with rod and reel a bass weighing 327 pounds-a feat accomplished only by a determined and continuous fight. During this time the fish towed the angler several miles, making a series of furious rushes before it was brought in, giving its captor the record of the largest fish ever taken with rod and reel. During the Tuna Club tournament every effort was made to break the record. Col. R. A. Eddy, of San Francisco, an enthusiastic member of the Tuna Club, took five black sea-bass weighing respectively $240,246,322,227$, and 196 pounds. Mr. F. V. Rider landed three fish weighing 175,182 , and 151 pounds; Dr. Bently three of 150 , 184 , and 165 pounds, and Mr. George B. Jess one of 145 pounds. These catches are quoted here as being very remarkable when it is remembered that each was made with a twenty-one-thread linen line, little larger than many anglers use for a five-pound small-mouth black bass. ${ }^{1}$

During these days Don Antonio was rowing. I frequently saw him in the afternoon, when the purple shadows were creeping out from the lofty cliffs along shore, near the tuna grounds; or he would be seen riding a heavy swell in the lee of the Sphinx, looking as imperturbable, as he chummed for his patron, as the great face bathed in the spray of the restless sea. On

${ }^{1}$ Since this was written, many much larger bass have been taken, and the record is held by Mr. L. G. Murphy, with a bass weighing $436 \mathrm{lbs}$. 
such a day I hooked a bass off the kelp beds and lost it, then with a camera photographed a more fortunate angler, whose boat was rushing away with a wave of foam beneath her stern, despite the vigorous efforts of the boatman. Again I hooked a bass that with a brilliant burst of speed took three hundred feet from the reel and carried the boat on with surprising force. It is always the largest fish that escapes, and this is usually the "record-breaker." I could hardly move it, and the, line sang and hummed like a lute touched by some mystic fingers deep in the sea. It was a question of stopping the bass before it reached the kelp bed, half a mile offshore. For twenty minutes I vainly lifted and essayed to reel, each moment the fish nearing the dreaded kelp forest.

The approved and only possible method of procedure was to raise the rod gradually with both hands, then lower it quickly, reeling as it dropped, but I believe I never swayed this monster far from the even tenor of its way. Exhausted, I handed the rod to a companion; he too failed, and the great fish, now but a memory, dashed into the kelp, and passed out of history, leaving a dangling line alone to tell the story.

It was near the end of the season that Don Antonio crushed his rivals among the boatmen of Avalon. The long days of summer were growing shorter, the cool winds that had made the island an ideal spot for angling were dying down, and day after day the sea lay like a mirror, its surface cut by shoals of innumerable fish. 


\section{The Rise of Don Antonio}

The sea-birds were coming down from the north, long, undulating lines of shags passed north and south, clouds of gulls followed the bait catchers, and the west at night became set in autumnal splendours and ineffable tints of gold and red. The delightful fall fishing season, September, was on, with two more fishing months to follow. A rain had cleaned the sleeping air ; the blue haze on the distant mountains softened the rugged outlines; the chaparral and trees took on deeper tints of green, all telling of the waning summer and the coming of the island winter, the season of flowers.

One morning when great bands of vermilion shot upward from the horizon, cutting deep into the sky, Don Antonio rowed his patron out from the vale of Avalon. The channel was calm, and the rhythm of the tide gave a gentle undulation to the kelp leaves that lay glistening in the rising sun. The tide was low, and all along shore the black beard of kelp brought out the rocks in strong relief. On the points eagles stood preening their feathers for the day; a school of sealions was making for the rookery after a circuit of the north shore, and as the boat rounded the point and entered the light green water a fair and smooth sea stretched away. Don Antonio dropped the anchor near the beach, half a mile above the rookery, in sight of the sea-lions that lay basking on the black rocks, arranged his rope to cast off at a moment's notice, placed his oars in position, baited his hook with three or four pounds of albacore, and while the angler made the 
cast began the chumming which is supposed to aid and abet the capture of fish in all climes.

The equipment of this black-sea-bass angler may be of interest. His rod and reel were designed especially for leaping tuna and black sea-bass; the silent reel was equipped with heavy, patent, anti-overrunning brake and leather thumb-brake, and held perhaps six hundred feet of twenty-one-thread linen line. The rod was a split bamboo, seven feet in length, with long butt and single joint mounted with agate guides. A six- or seven-foot bronze wire leader was attached to the line, the hook being the Van Vleck pattern-a singularshaped silvered hook in high favour among tarpon experts.

A light wind sprang up and swung the boat to the east, gently rippling the water. As the moments slipped away the angler leaned back in his chair, with rod across his knees, the line overhauled and between his fingers, as the big reel had no click, and glanced over the San Clemente Channel at the long, low island that loomed up in the blue haze. It was not a day of waiting. Presently there came an ill-defined tightening of the line; it might have been a drifting kelp leaf, possibly the shifting current; then it slackened, and the angler took his rod in hand, his right clasping the butt, the left caressing the cork grip above the reel, as he well knew that the largest of game fishes in the bass tribe are the most delicate biters. There was no mistake here; Don Antonio dropped his cigarette, threw off the 


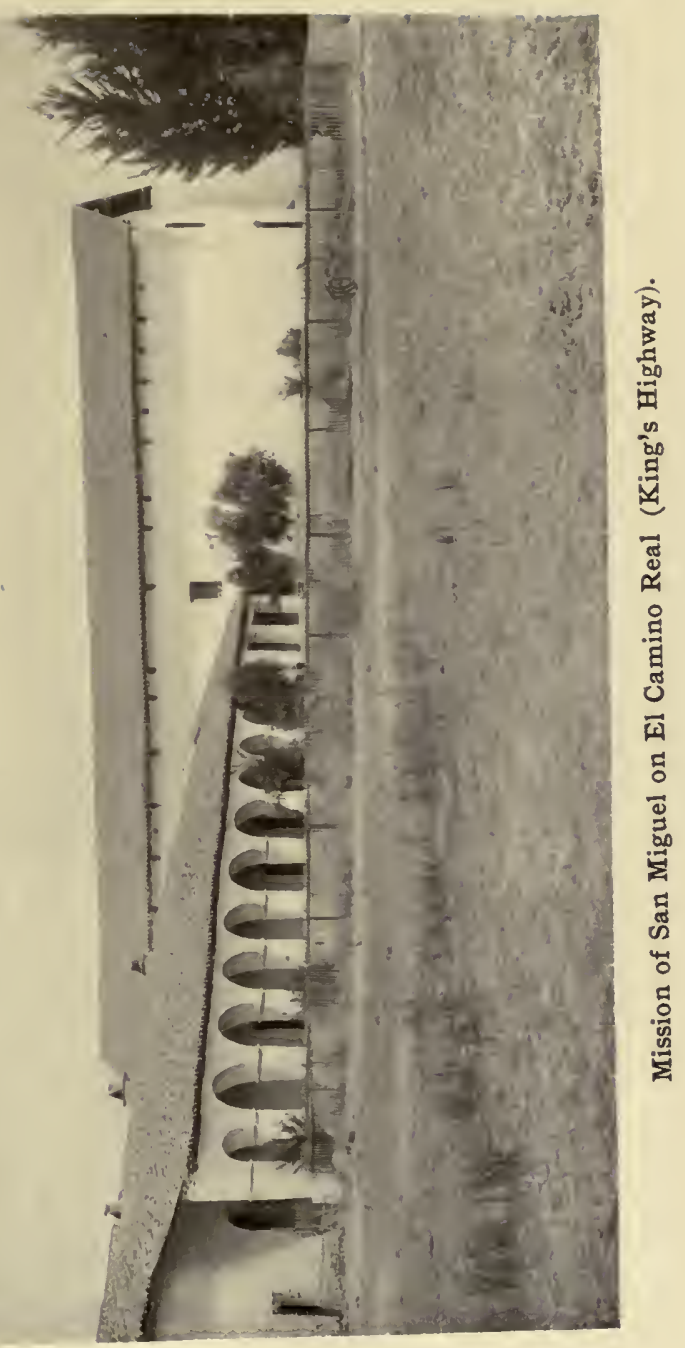





\section{The Rise of Don Antonio}

turn of the anchor rope, and held the buoy in his hand.

The line was slipping through the smooth agate guides, and Don Antonio, dropping into Catalina Spanish in his excitement, whispered hoarsely, "Ahora, ahora!" But not yet; the bass might have the heavy bait merely between its lips, to be jerked out by a too hasty strike. Another foot, until ten or twelve had gone, then the rod rose in a strong, well-directed strike, and the game was on. Stse-stse-ceese-ceese! went the line, hissing through the water, the silent reel unburdening itself to the measure. Over went the buoy, around whirled the boat, and bravely they were away. Stern first it surged, with Don Antonio holding back gently at the oars.

The rod pounded the air with terrific jerks and the xepert handling it was almost lifted from his seat by the impetuosity of the rush. Directly out to sea the fish went, headed for deep water, and as at this particular point there was no kelp, the combat was to be on its merits. In a few seconds the boat was rushing stern first into the swell beyond the lee of the island, a big wave beneath the combing stern. Ten, twenty, thirty minutes slipped away, and the boat was well offshore where the wind and sea were rising, and the angler meantime had accomplished little but hold the rod, vainly pumping with seven hundred feet of line out, the fish ever boring down. After a desperate effort it was turned, when it rushed inshore, and at the end of an hour was again towing them seaward. Sometimes a few feet of line would be gained and as many lost, the fish 


\section{Life in the Open}

adopting tactics designed to wear out the unsuspecting angler : rising suddenly to plunge down with irresistible force, to circle the boat, then run in.

Don Antonio all this time held the oars in silence, backing water, offering all the resistance possible, and keeping the stern of the boat to the fish. The sea was rising under the north-west wind, and to sit in the stern of the boat rushing against a heavy sea was to invite disaster. Once a big comber came surging in, and rein had to be given the wild steed, that fortunately turned inshore again, overrunning its former course. But it was presently a question of cutting away the fish or foundering, when the angler, in an inspiration, bethought him of a bottle of oil in the boat, and a moment later Don Antonio was pouring it over the side. The change was magical; the fluid mysteriously blazed a spot to the windward of the boat perfectly smooth, and presently the singular spectacle was witnessed of a low boat in the centre of a heavy sea, yet in a zone of perfect calm ten or twelve feet across. Here Don Antonio held the boat while the angler renewed the struggle, and, two hours from the strike, reeled the fish to the boat.

$\mathrm{Up}_{\mathrm{p}}$ it came, slowly swimming around in decreasing circles, and as its full proportions dawned upon him, Don Antonio made a fervent appeal to the saints. The bass seemed as long as the boat-a giant-and as it turned, its huge tail deluged the men with oil and water. It was then that Don Antonio reached out and gaffed the heaviest fish ever taken with rod and reel, gaffed 


\section{The Rise of Don Antonio}

it well. But what then? It struggled like a wild bull, threatening to carry the anglers down, and it was only after a contest that the bass was securely lashed astern; even then it could not be towed, as they were three quarters of a mile offshore. A passing boat, whose oarsman was a rival of the Don, was hailed and came down to them, and, with the camaraderie of sportsmen the world over, offered their services. By the combined efforts of five men the bass was hauled into the boat, the fish filling it, the crew taking to the other. In this way the bass was towed into Avalon, where it was forthwith triced up on a huge crane and weighed. "Three hundred and seventy pounds, señor." Little wonder that it had towed the boat eight miles and had been saved only by pouring oil upon the water. Very much after this fashion did the record pass to an angler from Philadelphia.

As Don Antonio walked through the little town that night, he was followed by Mexican boys who said in hushed tones: "It is he; he gaffed it." His victory was complete, and on the record book one may read after the entry of his patron's catch, "Don Antonio Oromo, boatman ; the largest game fish ever gaffed." 



\section{Royal atch}

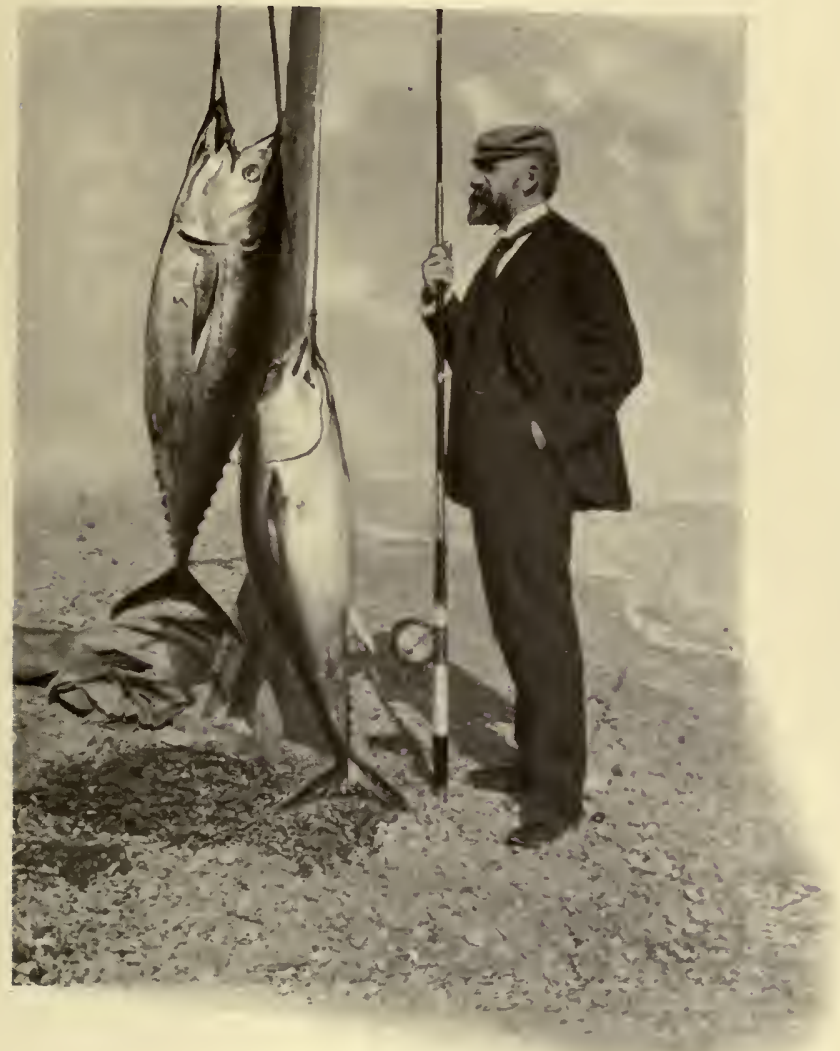





\section{Chapter XVII}

\section{The Royal Catch}

X ${ }^{\mathrm{HEN}}$ the early spring of California melts into summer, when the west winds freshen and sweep across the great current of Japan, the Kuroshiwo, the island of Santa Catalina, in Southern California, stands like an emerald in a setting of turquoise. Its crest is a vivid green; the deep waters that bathe its rocks and leap and foam in the shadow of its mountains are a steely blue, and they environ a fishing ground of many and varied delights.

Winter has. passed - a winter of wild flowers, of soft winds; and summer has come. You may know it by the gathering of the clans at Avalon, the little port and town of the island, where congregate in June anglers from all over the world, to await the coming of the leaping tuna, the great game fish peculiar to this place - or the big Japanese yellowfin albacore, Hirenagaso far as its capture with the rod is concerned.

Los Angeles is the point of departure for the tuna grounds; and twenty miles distant, reached by several 
railroads, is San Pedro, from whence the Cabrillo or the Hermosa, large ocean steamers, take the angler across the Santa Catalina Channel, thirty miles, to the island of that name, a great mountain range lying in the purple haze to the west.

Avalon is a miniature Naples, with the charm of colour in sky, water, and rocks that makes up the Italian resort. There are good hotels, from one to three steamers a day in summer, and one in winter, wireless telegraph, and a variety of sports and pastimes, from fishing for a remarkable assortment of big game fishes to hunting and riding over the mountains and cañons. But above all it is an angling community; the entire southern portion of the bay is lined with the fishing stands of the boatmen, each of whom has a certain number of feet of beach line, out from which extends a string of rowboats, tuna-boats, glass-bottom boats, and sailboats, - so many that the bay is filled with them. This bay is so clear and still, so glass-like, that the angler can hardly realise that he is not in some loch in Scotland, or on the St. Lawrence.

If one does not bring his tackle with him, the best can be purchased from any of the shops along the bay, and all the boatmen provide it. Tackle is a subject of vital importance here. The Tuna Club has established a sportsmanlike code as to tackle, and every year gives a tournament, offering valuable prizes to encourage the use of the rod. As a result, the giant fishes of these waters-the tuna, black sea-bass, yellowtail, albacore, 


\section{The Royal Catch}

white sea-bass, ranging from fifty pounds to four hundred-are taken with light lines and rods, the deadly handline being almost unknown. Good tackle, in fact the very best made by old and reliable makers, is essential, since a poor line or rod will often lose the day after a struggle of hours. The reel is known as a tuna reel, of rubber and German silver. It is large enough to hold six hundred feet of wet line. Such a reel costs from \$1 5 to $\$ 75$. It has a patent anti-overrunning arrangement, a brake or click, and to the cross-bar is attached a rubber or leather pad that can be pressed upon the line. This is the brake par excellence. The line is a 21 or 24 cuttyhunk. There are a number of makes; the $2 \mathrm{I}$ is large enough, and it is in this connection that the remarkable feature of this angling is seen. The number $2 \mathrm{I}$ is not much larger than the cord used for eyeglasses, yet a four-hundred-pound fish has been killed with it. The line costs from $\$ 3.50$ to $\$ 4$, and there must be no question about it; it must be true every inch of its length. The hook is a matter of fancy. I prefer the old-fashioned O'Shaughnessy, number Io/o, to my mind a perfect all-round hook, but the Van Vleck is one in good favour on the tarpon and tuna grounds. The leader is of piano or phosphor-bronze wire in two or three links, each connected by a brass swivel-in all, six or seven feet long. The line above this for ten feet should be doubled or quadrupled, for the gaffer to grasp, if necessary, after the gaffing, and for security against chafing when the tuna is boring down into the channel. 
The tuna rod is identical with that used for tarpon,seven feet in length, in two parts, a one-piece tip and a short butt. The latter is often of rubber, mounted with German silver, with the tip of noibwood, bethabera, or green-heart, weighing about twenty-five ounces. The rod may be of split bamboo. Such an one costs from $\$ 20$ to almost any price, but the typical $\$ 22$ or so tuna or tarpon rod is best.

The tuna is the king of the mackerel tribe, the royal catch, Thunnus thynnus of the scientist, a fish that attains a weight of fourteen hundred pounds and a length of fifteen feet; a world-wide rambler on the high seas, yet, so far as is known, all attempts to catch it with rod and reel except in Southern California have failed. On the Pacific Coast the tuna is rarely seen inshore or near the mainland, and of all the islands which are strung like jewels from Santa Barbara to San Diego, Santa Catalina is the one where the tuna is seen in greatest numbers. This is probably due to the contour of the island, which affords nearly twenty miles of lee calms and sheltered coves into which the tuna can drive its prey, the California flying-fish. This fish appears, and the tuna with it, anywhere from May first to July, though the latter is often an uncertain quantity. From May until November, sometimes December, a storm or squall of any kind is unknown. So pass the days away waiting for the tuna, days of dolce far niente. One morning some one looks out over the bay to the east where, across the channel, the snow caps of 


\section{The Royal Catch}

San Antonio and San Jacinto stand ten thousand feet in air against vermilion clouds, - looks and sees a mass of whitecaps in the midst of the calm, sees black objects leaping from the sea, and then Avalon goes mad.

"Tunas!" "Look!" "The tunas have come!" are the cries in "dago" Spanish, California Italian, HispanoMexican, and English. Every angler rushes for his rod and boat, and in a short time several trim tuna launches are darting out across the bay, while less fortunate anglers are hurrying hither and yon hunting for boatmen, boatmen are hunting for patrons who perhaps are playing golf, baitmen are rushing for the seine, and the whole fishing community is thrown into great excitement.

Meanwhile the boatman is baiting the hooks with the large-twelve-inch California flying-fish, the natural food of the tuna, impaling it so that the bait will move through the water in a natural position and not twist. The school of tunas is moving north and the boatman steers the launch to cross them. All being ready, the anglers wet their lines to prevent any burning off when the leather brakes are applied, slack out fifty or sixty feet, and sit with rods across the lap, one to port, the other to starboard, the tips at an angle of forty-five degrees, left hand upon the rod grip above the reel seat, and right thumb upon the leather pad which the skilled angler plays upon to kill the game.

On nearing the school, the fishes become more distinct and the splendid spectacle is afforded of large 
tunas feeding. A stretch of perhaps twenty acres is a mass of foam. Some of the fish are playing along the surface, churning the blue water into silver. Some are leaping high into the air, going up like arrows, eight or more feet. The boatman is bearing off and is several feet ahead, but suddenly slows down to half speed. Big flying-fishes are speeding away in every direction a foot or more above the water, looking like gigantic dragon-flies. Now the bait is in the line of march of the school. The boatman stands like a statue, his hand on the little engine, ready to stop and reverse. Suddenly he whispers, "Look out, sir!" his voice hoarse with what should be suppressed excitement, and two or three flying-fishes cross the exact location of the baits. He knows that a nemesis, one or more, is directly behind. Then comes a rush of something, a blaze of silvery foam along the surface, tossing the spume high in air, and two rods are jerked to the water's edge, while the reel gives tongue in clear vibrant notes like the melody of an old hound that one angler had known in the Virginia fox-hunting country long ago.

Zee-zee-zeee-eee! rises the music, the symphony of the reels; now a duet, both joining and giving out longcontinued notes as the line is jerked away in feet and yards, in veritable handfuls. In the meantime the school is closing about the boat and there is fear that the lines will be cut by the crazed fish. Fisherman's luck! one breaks-perhaps too much pressure was put upon the brake, perhaps the sharp fin of a tuna cut it. 
So one angler slowly reels in, and watches the play of his more fortunate companion.

The boatman has stopped the launch at the sound of the reel, and is now backing her slowly, so that the angler may not lose all of his line. The slightest mistake, a fraction too much pressure on the thumb pad, a little overdue excitement, a mild attack of buck or tuna fever, any condition away from the normal, and the game is up, as the line can be snapped by any jerk, and is seemingly an absurd thing with which to fight so powerful a fish.

But this angler is an old tarpon fisherman. He has seen the silver king vault into the empyrean, has seen it flashing, coruscating, caracoling in the sunlight, so that he seemed to be playing a fish in mid-air. He has his nerves well in hand, and slips the butt of his rod into the leather socket, and follows every move of the game by the agate tip. Down it goes, fairly into the water, as though struck by repeated blows. Zee-zeeezeee-e-e-e-e! the music of the gods, the echo from the strains in the dark, unfathomed caves, perhaps, where this wild game has plunged.

Every hundred feet of line is marked by a "telltale" band of red silk, and the angler has watched three and a green one, indicating fifty feet, slip through the silver trumpet guides, and still the fish is going; yet but a few seconds have passed. Four hundred feet, and a little shower of leather filings has collected in the reel near the pad. The launch is going at full speed 
backward, the angler is pressing upon the brake and lifting with all the power the line will stand. Five hundred feet as a red dot flashes up the rod; then the pressure stops, the first rush is over, and the angler slowly lifts the slender rod, which is bending to the danger point, yet holding. The boatman has stopped the engine and that angling miracle is seen, a tuna towing a heavy launch by five hundred feet of a number twenty-one thread line. It is asserted by some who have not seen it that this is an impossibility, yet it is done every day when the tuna are biting along the isle of summer.

The fish is slowly rising; the school has passed on, and the singing of distant and other reels is heard. Enthusiastic, but less fortunate, anglers pass by, and rise to give the sportsman cheer and wish him good luck; they are warned by the boatman, who considers social amenities totally out of order, to keep away from the line, as any man with a fish hooked is entitled to the field. Up comes the tuna, imparting to the line a quivering motion until it reaches the surface, when it turns and comes along the surface like an arrow.

The angler springs to his feet, that he may see the splendid move, and reels for his life. No power, no multiplier, could eat up the line to match this racing steed that comes on and on, a blaze of silver, gold, and blue, tossing the water within ten feet of the boat, where it turns in a miniature maelstrom and is away. But the angler meets it, stops it again: and so the battle goes on, and an hour slips away. 


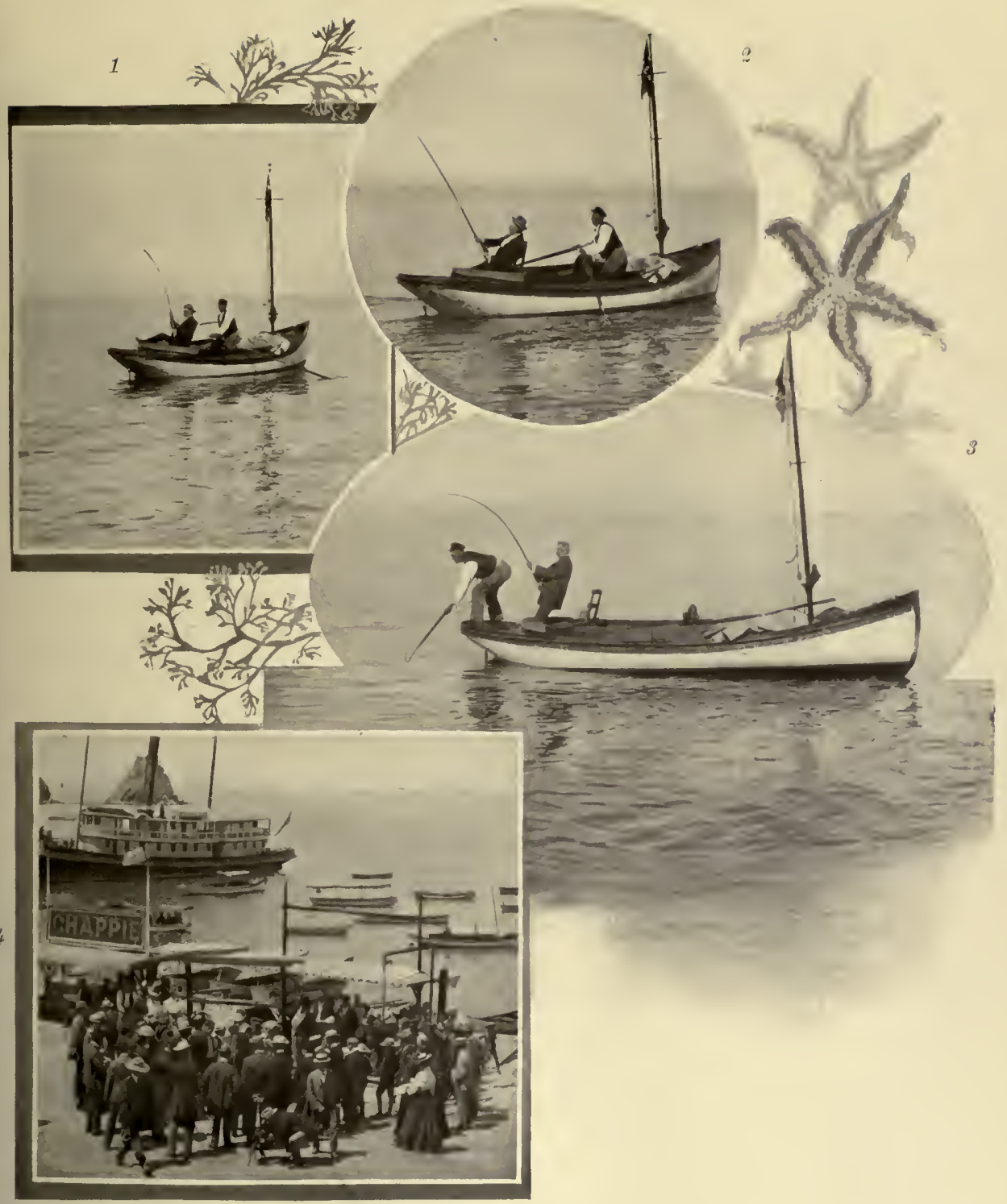

Landing the Leaping Tuna.

(1) The strike. (2) Rushing in on the boat. (3) Boatman Neal at the gaff. (4) Weighing a Tuna. 



\section{The Royal Gatch}

The fish repeatedly rushes in, trying to take the angler at a disadvantage ; then plunging to the bottom, to rise like a bird to the surface, and circle the boat, then towing it a mile to sea, where it turns and literally goes crazy in a series of evolutions, at the end of which it has been brought within a few feet of the boat. Again and again this has been accomplished. Again and again the angler has felt himself going under the tremendous pressure, but hope shines like a star somewhere in his heart; he has determined to land that fish at any cost, and never relinquishes his hold upon the rod or reel. Almost an armistice is called. It seems wellnigh impossible to bring the fish nearer. Seeing the boat, it breaks into a frenzy, bearing off with such violence that disaster hovers about, too near for comfort.

Lifting, reeling, pumping, holding fast, the fisherman always feels the continued strain which tells that the tuna has never lost a scintilla of its strength and vigour, is still fresh, while it long ago began to tell on the man, indeed on the nerves of one looking on. Suddenly, after three hours and a quarter, the fish turns and swims away to the south, dragging the boat, occasionally stopping to rush in; but at the end of four hours, within three hundred feet of where it was hooked, and after a last run of four miles, the tuna is brought to gaff. Ten or twelve miles it has towed the boat up and down the coast, ten miles of fighting. ${ }^{1}$ The

1 The author's record fish, the first large tuna taken, weighed $183 \mathrm{lbs}$. It towed the boat, against the boatman's oars, ten or twelve miles in four hours. 
weary angler stands and leads it into the field of the gaffer, and as the steel sinks into its silvery flesh below the jaw, it makes a supreme effort and plunges, shattering the gaff, making fifty feet. There 's many a slip between gaff and line in catching tunas!

Again the angler rallies and a fresh gaff hits the mark; the angler slacks away, and all stand upon the rail as the gaffer slides the splendid fish into the boat, a monster in gold, silver, and azure, which later on tips the scales at one hundred and fifty pounds. A few ponderous blows on the flooring, a strange, penetrating quiver, and the king is dead. Up runs the flag of victory, bearing the blue tuna, shattered nerves and weary muscles are forgotten, and the boat runs in amid the cheers, whistles, and salutes of the lookers-on in boats who have been watching the catch and the often heartbreaking struggle.

That afternoon the angler wears a little blue button. He has taken tarpon, perhaps the weird rohu and mahsir that Kipling sings about ; but he would not exchange his experience with all these for that four hours' battle with the leaping tuna along these placid waters.

So delightful are the conditions of the sport at this isle of summer that they become compensations even for occasional poor luck, as even tunas are uncertain and seasons have been known to pass when the fish, over one hundred pounds in weight, absolutely spurned all lures. The winter here is the time of flowers, or from the coming of the rain, from November to April, 


\section{The Royal Catch}

during which ten or twelve inches will fall; a rainy season in name only, for from May until November, and sometimes December, a storm of any kind is unknown on these fishing grounds, while extreme heat is a stranger to the vale of Avalon. Day after day the bays and coves are disks of steel, and the angler drifts along in the shadows of the lofty cliffs, in the enjoyment of absolute relaxation, and the best of sea fishing.

There is another feature which makes rod tuna fishing possible here. The tunas at Nova Scotia and other localities on the Atlantic Coast average six or nine hundred pounds. Large fishes predominate, at least this is my experience. I have collected data from I 850 on, and such game is doubtless beyond the field of the rod angler. On the Pacific Coast very large tunas are rare, the record rod catch of Avalon, held by Col. C. P. Morhouse, weighing but two hundred and fifty-one pounds, the average tuna seen being one hundred and fifty down to seventy pounds. This accounts for the number caught, a number large when the agility of the fish is considered, but small in reality.

It is these conditions, the absolutely quiet water of the Kuroshiwo as it flows down the coast, which have produced this tuna ground, a veritable paradise for good anglers. The angler who has fairly killed a tuna weighing over one hundred and fifty pounds after a constant fight of four or five hours has accomplished, in my opinion, a feat more difficult than shooting a tiger from the back of an elephant or a lion from cover. I 
have always had a fondness, more or less unreasonable, possibly, for large game of the sea, and have taken almost every hard fighter from tarpon to the giant-ray, but award the palm of hard fighting to the tuna at its best. Some weakened by spawning or other causes can be landed in ten minutes with a club-rod, and strong women have landed this fish, but the one-hundred-and-fiftypound tuna in the best condition is game for men in their best form, and such a fish will fight until its heart stops beating. 


\section{Goaching Santa Gtalina}

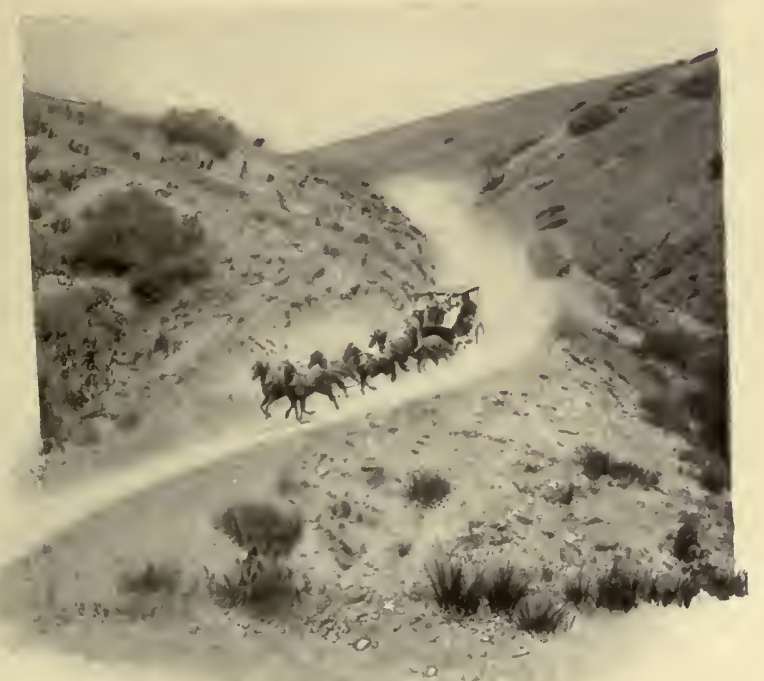





\section{Chapter XVIII}

\section{Coaching at Santa Catalina}

7 HE Pacific coast of North America has long been famous for its coach lines and the men who held the lines. Before the advent of the railroad six-in-hand coaches carried passengers all over the State. One line ran from San Francisco to Los Angeles, five hundred miles; from here another ran to San Diego and over the desert to Yuma, Santa Fé, and the East. This difficult service developed a peculiar class of men or drivers, noted for their courage ; daring men who would take a mountain road at full speed where there was not a foot to spare. The early pages of California history are filled with stories of the marvellous exploits of these men. The coming of rail and electric roads has almost driven the stage out of business in Southern California. There is a notable exception at the island of Santa Catalina. The island is really a spur of the coast range, separated from the mainland by the Santa Catalina Channel; a jumble of picturesque peaks running in every direction and worn into thousands 
of deep picturesque cañons by the rains of centuries. At most points the shores are abrupt, no beaches appearing; the mountains rise directly from the ocean, affording but a shelf as a vantage ground. This is particularly true of the south-west side, where no landing can be made for miles, except where a cañon has formed, its mouth marked by a sandy beach of pure white against which the surf piles in. The one town, Avalon, is made up of hotels, cottages, shops, and a large fleet of boats for the benefit of anglers from all over the world. It is situated in the mouth of Grand Cañon, one of the largest of the cañons at the south end of the island; the only other settlement is Cabrillo, at the Isthmus, about fifteen miles away, a maze of mountains intervening. The two places have long been connected by a trail by which wild-goat hunters made their way up the sides of the mountains to the interior; but as the population grew it was evident that a perfect road was necessary, so several years ago a stage road with a low grade was begun, started at both ends, winding up the mountains from Avalon to the Isthmus, one of the most extraordinary pieces of road engineering, in all probability, in the country, owing to its sensational features and the apparent difficulties in the way of its completion.

Lovers of coaching - and by this is meant mountain coaching-doubtless form a class by themselves, but it is difficult to understand how any one fond of sport that has an essence of daring in it cannot enthuse over this 


\section{Coaching at Santa Catalina}

splendid road, that in point of insular scenery and contrast between mountain and ocean has no equal.

The start is made at Avalon, the coach pulling up to the hotels in the morning, the passengers booked taking their places soon after nine. The drivers are characters; all have histories. One was a driver in the Arizona mountains for years-his stories of hold-ups and adventures would fill a volume; another is an old Yosemite driver, familiar with curves, precipices, and dizzy trails-men who never get "rattled," and who thoroughly understand their business. The road takes us up a street of the little town, turns sharply, rounds a point reaching into the sea, and in a few moments we are high above Avalon, its crescent bay standing out in relief, the blue Pacific stretching away in every direction. A sudden turn is made and the road is seen climbing a shelf on the side of Descanso Cañon that reaches the sea parallel to Grand Cañon, separated from it by a spur of the mountains. The road is perfect, and the horses are obliged to walk slowly to the summit, perhaps three miles by the winding road. At every turn the driver has a story to fascinate the tenderfoot on the box seat.

"I call this Rattlesnake Point," said the driver, flicking his whip at the place which appeared to hang over the ocean, one thousand feet below.

"Why?" asked the young lady who had the box seat.

"Why," echoed the driver, glancing at her, "as I 
was coming down one day I saw a big rattler in the road, and pulled up the team just in time to save it. The next trip, there was the same snake in the same place, and as we went by it crawled after the stage; so I got out and put it in a box and took it down to Avalon. That snake was the gratefulest creature you ever heard of ; tried to follow me all over. You see, I'd saved its life. When I went to Los Angeles one day I took it along and left it in my hotel when I went out. When I went back I heard a noise, and looking up to the window I saw that rattler's tail hanging out and rattling so you could hear it a block. I went up as quick as I could, thinking the window had fallen on it, and what do you s'pose I saw ?"

"I can't imagine," said the young lady from the East, with a look of horror on her face.

"When I pushed in the door," continued the driver, "there was a burglar lying on the floor. The rattler had the thief by the coat, and its tail was out of the window, rattlin' for the police. And yet," the driver added, glancing out of the corner of his eye at the young lady and tossing the long lash at the leaders, "some folks say animals don't think, and snakes is cold-blooded.'

Every foot of the rise gives the rider a new vista of mountains and ocean. We are now half-way up, making a sharp horse-shoe curve. The deep cañon drops completely away or the right; we can toss a stone that will roll a thousand feet. The trees at the bottom look like 


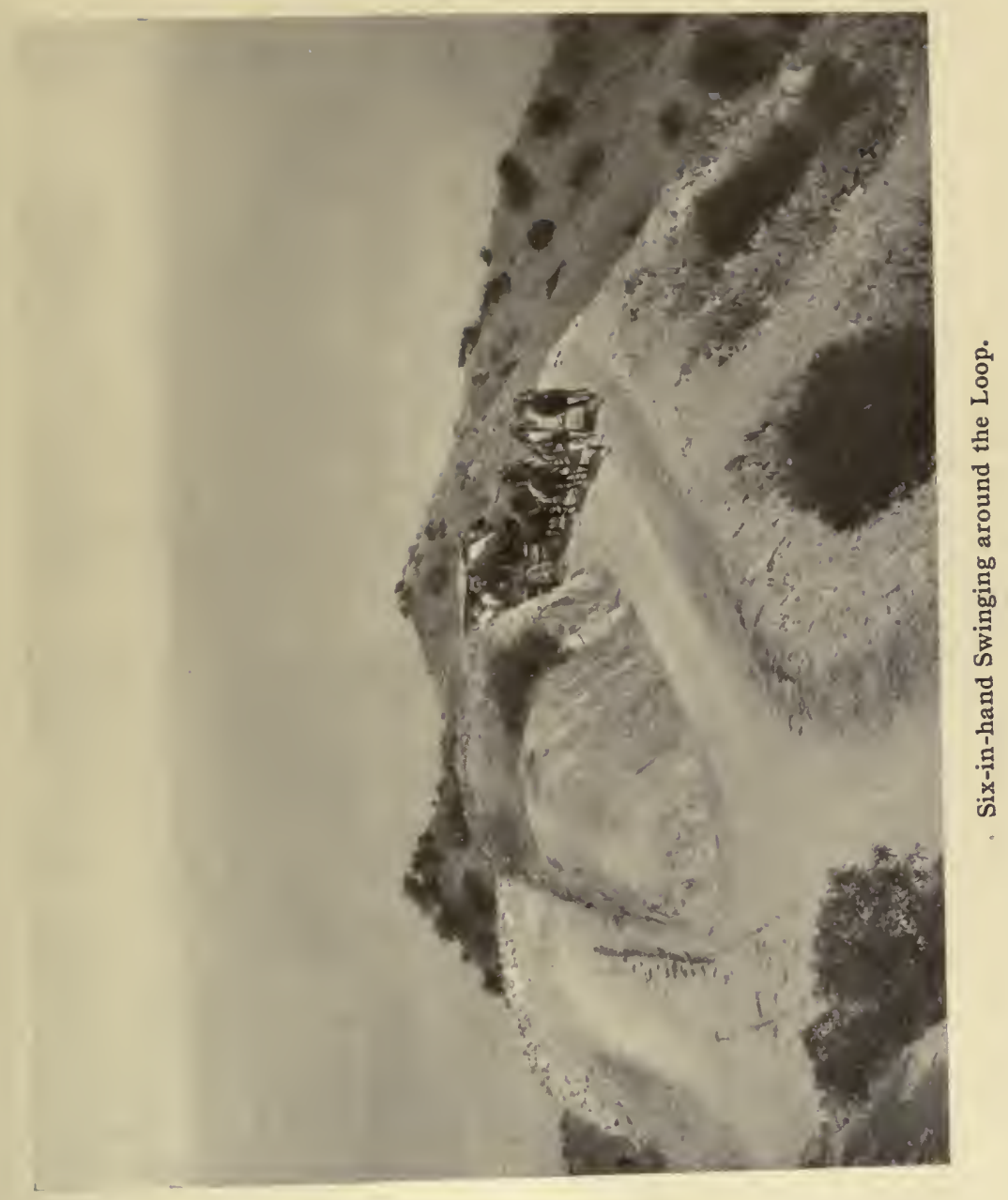





\section{Coaching at Santa Catalina}

bushes and the sails of vessels are like gulls below us, while facing us are the lofty Sierra Madres, capped with snow, forming the edge of the world.

The coach is always following the indentations of the cañon. This road is but a shelf fifteen feet wide, cut out of its side. Now we are facing the mountains, now seemingly walking into the ocean, or about to drop into space. Ever rising, new peaks come into view, new points; ranges of purple mountains, silvered with flecks of gray; and so on, until the horses step out upon the loop-a clever turn, where the lady on the box seat looks into space and practically sees the two leaders coming toward her, so sudden is the curve.

Higher the horses climb, finally stepping out upon the hilltop at the summit, fifteen hundred feet up, where they face the sea, commanding a view perhaps without peer in America. The entire island is seen, a maze and jumble of peaks and ranges so high above the ocean that the ships below appear like chips floating on its surface. The walk up of the six horses has taken possibly an hour and a half. You can if you wish go down in eighteen or twenty minutes, if it happens that you are in the stage that does not go through. I have taken it many times, and am prepared to award the palm to this splendid ride as the most exciting in my experience. It is the acme of coaching possibilities, exhilarating and perfectly safe. The regular drivers are only allowed to make the descent at a certain speed, but I have taken it a number of times with Captain 
William Banning, one of the owners of the island, and one of the most skilful amateur whips in America. Then the six horses were "let out," and thefull delights of mountain coaching were realised. With the driver's foot on the heavy brake, lines well in hand, the coach would start, the horses gaining speed until all six were running down the incline, not prancing, but on a dead run. Nerves were left on the summit, or packed in the boot, so there was nothing to interfere with the complete enjoyment of the scene.

I was impressed by the splendid handling of the six horses on a road where a fall, a break, or a wrong turn meant something. The driver had them absolutely in hand, and the spirit was infectious. We were literally running down a mountain cliff at full speed. Now the horses would make a sharp turn, the wheelers disappearing around the bends; but so deftly was the brake used that the coach turned safely, gradually slowing up at the right moment. Then on the long, steep incline, the horses increased, if possible, their speed. Now they turn at the head of the cañon, rising on the incline; now rushing out onto the loop, the leaders seemingly in the air, but turning so quickly and suddenly and easily that the wheelers are going one way and the coach another; but this is for only a moment. The coach crosses its own track, doubles on itself, and plunges down the road or shelf, seemingly into the blue waters. One feels like taking off his hat and cheering; it is like dropping out of a balloon, the sky and mount- 


\section{Coaching at Santa Catalina}

ains seemingly moving upward, the horses rushing into the sea. There is a roar of wheels grinding over hard roads; a musical clanking of buckles and trapping, the snap of a long lash; words from the driver that the horses understand. They appear to be running away, yet it is merely as clever a piece of driving as one could well imagine; all six horses are running loosely in the harness, and the coach is being managed by the brake. No words can describe the sensation of this gallant run, this exhibit of skill that is all too short. The horses dash out onto a point seemingly into space, then wheel around the lower trail, sending clouds of dust over the edge of the precipice, and roll into Avalon town amid the cheers of the observers who have been watching the descent.

"Eighteen minutes from the summit," some one says, and you think it must have been a mistake. It surely was instantaneous, a John Gilpin dream.

If the return ride is not taken, the coach moves on from the summit along the north face of the island; crossing some of the deepest cañons, affording a series of fine views of ocean and abyss. Suddenly the road turns at the head of what is called Middle Ranch Cañon, and the horses gallop down into the heart of the island. The cañon deepens and a brook appears; now running through an arcade of willows, between masses of the wild rose, if in early spring, which fill the air with perfume. Flocks of the plumed quail rise here and there, and countless numbers run along the road before the horses. 
Deeper grows the cañon, the road winding in and out, now in a wide valley with the Cabrillo Mountains on the left and low foothills reaching up to Mount Black Jack and Orizaba's rugged rocks and peaks, about whose summit the wild goat makes his home. The cañon narrows again, and tooling, bowling down a sharp descent, the coach reaches the Eagle Nest Inn, beneath a clump of cotton-woods. Here one may sit in the door-yard and listen to the musical notes of the plumed quail that fill the glades, and the rush of the brook after the winter rain, or the booming roar of the ocean that comes up the long cañon from the south shore.

Here is refreshment for man and beast; we listen to the tales of the goat hunters, who are making their headquarters here, then again take our seats, and the coach winds away out of the Middle Ranch Cañon down by the big spur of Orizaba which is an island divide. About five miles from Eagle Nest we come to Little Harbour Inn, where two perfect and diminutive harbours face the west, affording a fine view of the rocky coast up and down the island. The cliffs are precipitous in the extreme; but the feature which will perhaps attract the attention of the man on the box seat or in the saddle will be the succession of evidences of prehistoric occupation pointed out by the driver. To the south of Little Harbour a level plateau rises above the sea, the site of an ancient Indian town, hundreds, perhaps thousands of years old. I found it fifteen years ago, and there are many interesting evidences of human occupa- 


\section{Coaching at Santa Catalina}

tion on the beach. Below the inn, at Little Harbour, are several shell mounds left by the ancients in which have been found many articles in stone, shell, and wood; and from here eight miles, to the Isthmus, there are many evidences of similar remains. The stretch of road remaining is interesting as it plunges into the centre of the island again; now climbing the hills, passing through groves of dwarf oak or by vast areas of cactus, yellow with blossoms. Climbing the mountain slopes, the road affords views of the Pacific to the west in the direction of San Nicolas and San Clemente; then suddenly crosses the divide five hundred feet above the Isthmus at Cabrillo, with its crescent-shaped beach, its groves of palm and eucalyptus.

Here the driver has a fine descending road in which to entertain the lovers of fast driving. It happens that all the passengers wish to be so entertained, and they request him in a body to "let them out." To say that he responded is putting it mildly. The old driver outdoes himself, and in a few seconds the fine team that has been changed back at the inn is galloping down the road at fuil speed. The skill of the driver, the manner in which he sends the six running horses around impossible curves, is beyond description. A moment ago we were standing on the divide where we could almost toss a stone into the blue water, five hundred feet below; now we are rushing down the incline and round up in gallant fashion at Cabrillo. Tobogganing cannot be had at Santa Catalina. but in this stage ride you have a 
substitute without any of the discomforts, and the ride down either end will linger long in your memory.

Cabrillo is the site of one of the largest ancient Indian towns in California. It is a vast kitchen midden. Houses and stables are built over mounds of bones and abalones, and here tons of stone implements have been dug up, and taken to the British and other museums in England and America. As a pleasant diversion the coach ride ends here; the party may return by coach if they wish, but the trip includes a trip back by launch, fifteen miles down the north coast to Avalon, which affords the coacher a complete view, near at hand, of the attractive and picturesque coast, and enables him to see the coach road over which he has passed from the ocean; caves which cut deep into the rock; lofty cliffs, fair reaches of mesa, lofty peaks and jumbles of hills, winding cañons forming little beaches here and there, make up the panorama as the yacht dashes along near the rocks, over the famous tuna grounds that are known to anglers the world over, finally reaching the vale of Avalon in the afternoon, after a round trip of perhaps forty miles through a region that has a most romantic interest, being in 1540 the home of a vigorous race, which, like the buffalo and other original inhabitants, have long ago been wiped out of existence.

This stage road has been extended five or six miles north of Cabrillo, reaching. Howland's, an attractive little bay on the north-east coast near Ship Rock-the finest fishing ground about the island. Another fine 


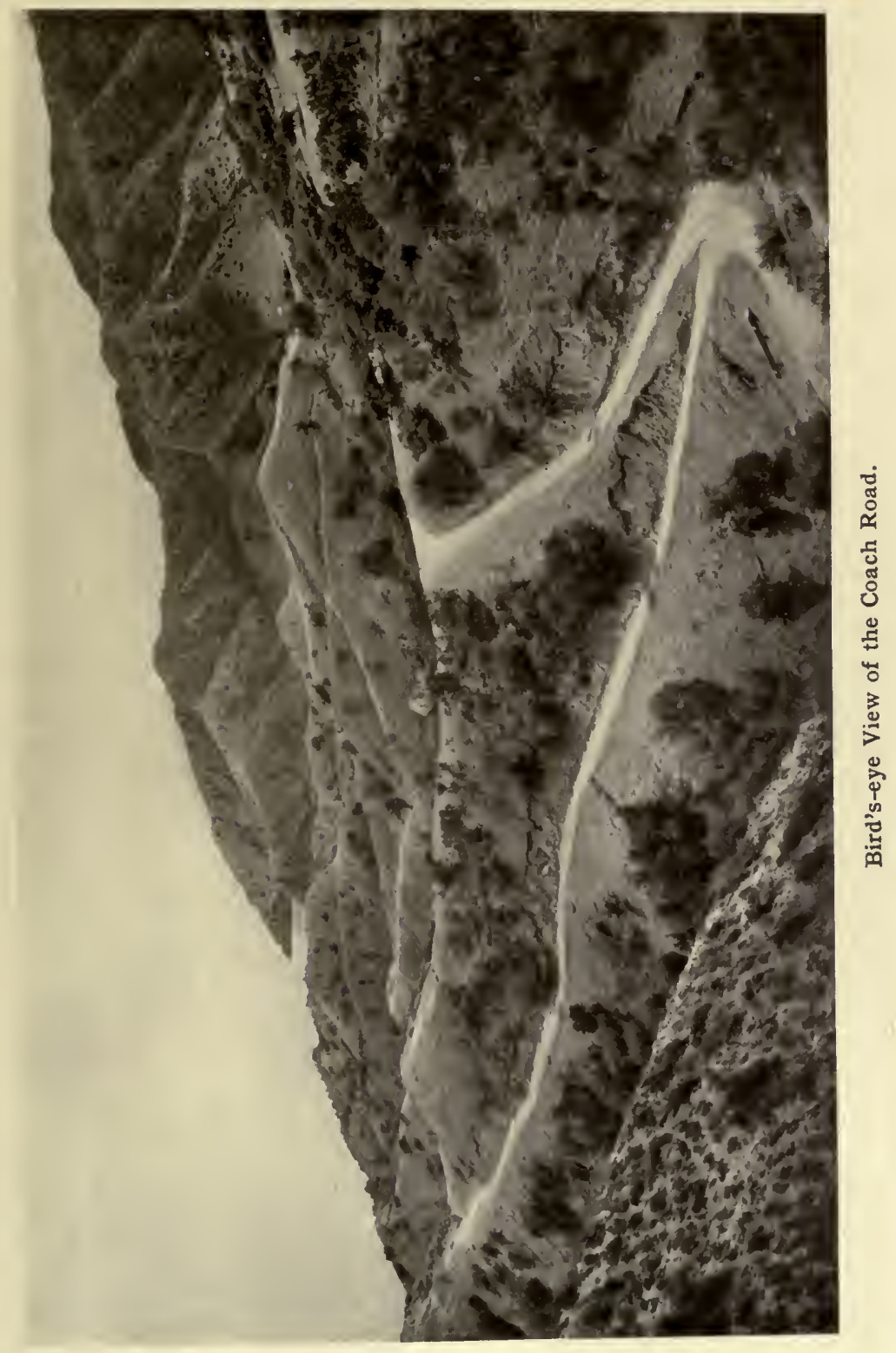





\section{Coaching at Santa Catalina}

road leads from Avalon south to Pebble Beach ; all these roads are available by carriage, saddle horse, or automobile, all of which find place on the island. Some day, perhaps not far distant, the electric car will supersede the coach, and the tourist be whirled along the mountain trails; but even this cannot rob this marvellous road of its beauties.

The stage line does not run at all seasons, but to the wild goat or quail hunter the road and trail are always open, and on horseback the mountain lover will find the trip to in every way repay the effort. The stage driver is a luxury, but not an essential. 



\section{The \\ Sea Lion's Den}

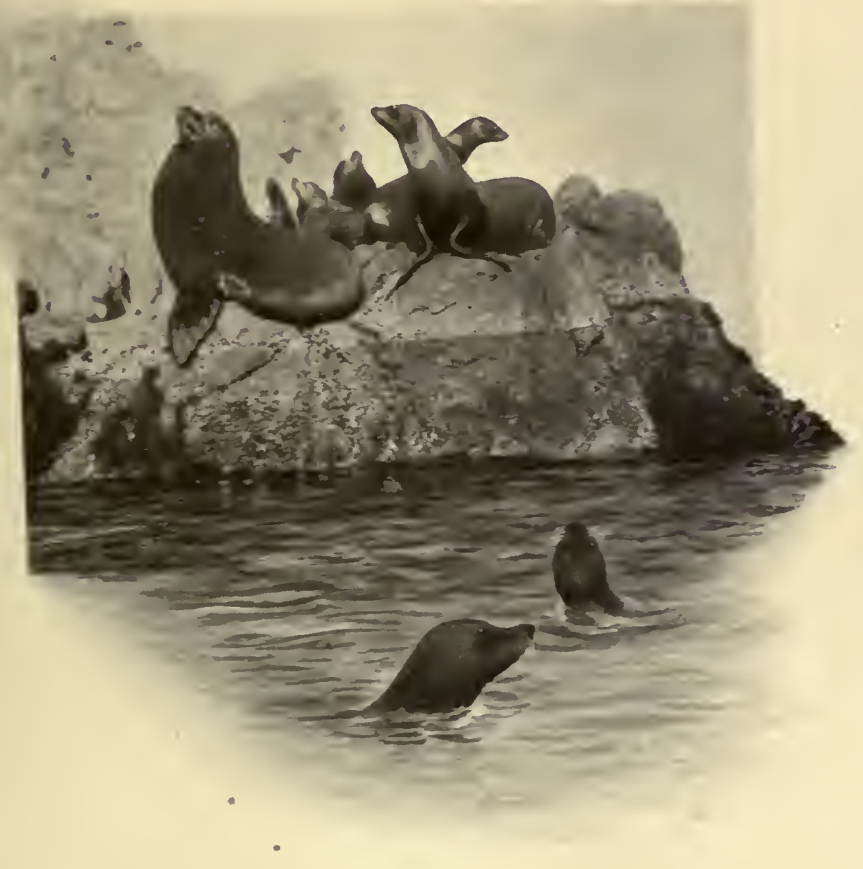





\section{Chapter XIX}

\section{The Sea-Lion's Den}

HE Pacific islands off Southern California abound in sea-lions, which afford excellent

1 sport, but not with the rille. The hunter must satisfy himself with the camera, as the animals are protected, but the hunt is exciting, owing to the close proximity of the game, and in some instances its absolute fearlessness. One huge bull, weighing nearly half a ton, comes out upon the beach at Avalon to be fed at times.

In riding over the mountains of the islands, from Santa Rosa to Santa Clemente, one may hear roars and bellowing coming from hundreds of feet below. If one has the curiosity to locate these sounds and find out what they mean, he may follow down the deep, rocky cañons that reach to the sea, or crawl down the face of the cliffs to come suddenly, perhaps, upon the rookery of the lions of the sea, that can be found along-shore in isolated places.

In years gone by these islands gave shelter to I9 289 
myriads of these animals, but they have been gradually decimated; driven from pillar to post, until the great rookeries are reduced to a few. Fifty years ago, at what is known as Catalina Harbour, there was a herd of sea-elephants, animals doomed to extinction, but they were so tame, and at that time so valuable for their oil, that they were mercilessly destroyed, and to-day it is very doubtful if a single sea-elephant could be found on the western coast of the United States, the last few specimens having been killed off in Lower California during the past five years.

On the island of Santa Catalina the sea-lions have been protected, and on the south end of the island is the finest rookery known, when the tameness of the animals is considered, as they permit visitors to approach within a few feet of the rocks and photograph them. The bulls here are of large size, and they have recently divided and formed a rookery near Long Point, on what is known as White Rock. These lions are several times as large as a common seal, and while the latter has a short neck, that of the former is long and snake-like, and the animal has a ferocious mien. The big mouth is filled with sharp teeth, the animals being very active, appearing like huge black slugs.

The sea-lions go ashore in June, and the young soon appear on the sands at the base of the great coloured cliffs, taking to the water when approached; but easily tamed. At this time the entire herd leave the 
rocks, where they lie in the sun and keep up a barking that can be heard a long distance.

The sea-lion is a very clever animal, lying on the rocks during the day, basking in the sun; and as the latter disappears, he tumbles overboard, often swimming twenty or thirty miles up the coast, going at a rapid rate, entering the bays, especially those where fishermen make their headquarters. In Avalon Bay the barking of sea-lions can sometimes be heard all night, one or more remaining there until all the fishes thrown overboard are removed. They are so tame that fishermen, in washing fish, have had it snatched from their hands, and they will often follow fishermen about and steal the bait as fast as they can put it on, yet never appear above water, the angler thinking it a fish, the sea-lion just bringing the tip of his nose to the surface to breathe. Sometimes during the day you may find them lying in the kelp beds, and they rarely venture far from shore, as there the big orcas and sharks chase them. An orca was killed up the coast at Soquel some years ago that contained five sea-lions.

In all probability, one of the most remarkable sealion rookeries in the world is in the Painted Cave, at the island of Santa Cruz, one hundred miles north of Santa Catalina, where boats can be chartered for the trip, or at Santa Barbara, directly opposite. This cave leads in under the mountain at Point Diablo. As I tried to land on the slippery ledge of a rookery not far from here, intending to go ashore, the sea-lions came 
rushing down the rocks, one big bull charging me with mouth open, thinking to drive me off; but as I stood my ground he sheared off, and plunged into the ocean with the rest of the herd and swam off with wild barking roars.

The opening of the Painted Cave, from the sea, was an arch about fifty feet in height, leading into a large room beautifully coloured red, pink, blue, green, and yellow from the staining of the rocks by salts. From this we rowed the boat into what was really another room, thirty or forty feet high, the water being ten or fifteen feet deep, as clear as crystal, the bottom a mosaic of colour. We were rowing into a sea-cavern, and when possibly about two hundred feet in we came to a small opening about the size of our boat, there being just room enough to float in after a wave, from which came roars, screams, and demoniac sounds sufficient to raise the ancient dead of Santa Cruz. Every few moments a wave would come rolling into the cave, passing from room to room, and on reaching the small orifice, or entrance, in front of which we drifted, would close it completely and part of it go into the unknown with a roar of sounds that was appalling. Waiting until a wave had passed we pointed the boat in and ran her into the den of lions, coming out into a room of large size where absolutely nothing could be seen. Lighting a flambeau only made the darkness more profound. We struck two planks together, producing a sound like thunder, the noise rolling away off into 
what appeared to be other rooms, echoing and reverberating from passage to passage, until lost in the distance, suggesting that the cave had endless ramifications. The roar from sea-lions came from all about us, and from seemingly distant caves, producing a series of sounds that one might believe issued from the bottomless pit. Cries of fear, rage, pain, horror, and despair were easily imagined. I can give no better illustration of the effect those cries had upon the human ear than to say that my companion and host, the owner of our yacht, failed completely in trying to induce some of his crew to enter the cave; they refused point blank, and could not be ordered in; so we rowed ourselves and the men remained aboard.

I felt around the edge of this cave, and found a sort of shelf on which the sea-lions evidently rested. I could hear them plunge over as we approached, and could see the flash of phosphorescence as they dashed through the water adding to the uncanny nature of the situation.

Some of the cries or barking of the sea-lions seemed to come from a long distance under the mountain, and, while it was mere conjecture, I should say four or five hundred or more feet, seemingly carrying out the idea of the men who believed that the cave ran completely under the mountain and was a den of not only sea-lions, but other creatures of the sea. All the sealions dashed for one starlike spot in the cave, the opening through which we came; and as we passed out I saw 
some swimming beneath the boat, joining a herd beyond the entrance, when they swam away to Point Diablo, with necks out of water, hurling at us literal yelps of fear and rage. The story is told of two boatloads of men who went in here to capture sea-lions. One boat remained at the entrance to keep them in, while the other went into the cave. As a result the lions rushed at the opening and, finding it stopped, clambered into and over the boat, sinking it and injuring some of the men.

At the present time the place where sea-lions are mostly caught is on the south-west side of the island, where the sea often makes a breach against the high cliffs. In an isolated cleft of the rocks is a large rookery impossible to reach in rough water, but so situated that the herd cannot well escape when the men go ashore. The latter are skilled cattlemen, who go over on a power launch, anchor off the island, and wait for a day when the lions are all on the rocks. Then the boats work carefully in, watching their chance, the rowers backing water and holding the boat on the big waves until the sea-lion hunters have an opportunity to jump ashore. Generally two or three men make the attempt at one time, and drive the lions back for some distance into a cul de sac.

When the animals find they are cornered, they turn and charge the men, and it requires no little nerve to stand and face the open mouths of the roaring animals, which come on with a curious galloping, menacing motion. It is at this psychological moment that 


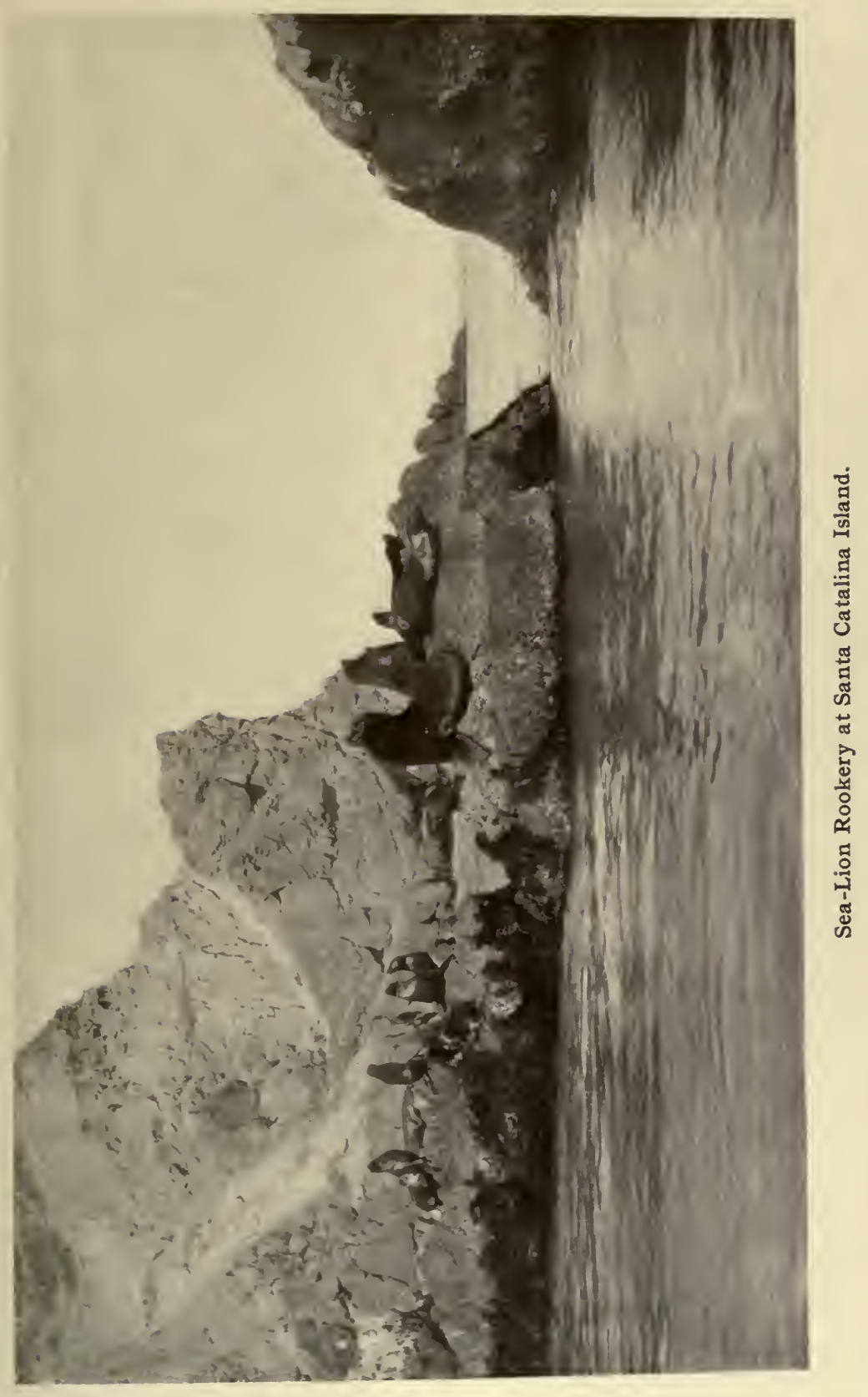



the men use their riatas, and thus rarely miss the lions, who hold their heads high in the air, presenting an easy mark for the roper. The moment the riata falls and the game is caught, the men dash for the rocks, where they can take a turn with their ropes. The lions make a desperate effort to escape; some break away, bite off the rope, or slip it over their heads; others reach the water, and the men have to be active to escape the horde of crazed animals, some of which weigh a thousand pounds, which come sliding down the kelp toboggan. After a long struggle the sea-lions are mastered; the most troublesome are gagged and bound, thrown over and towed to boxes into which they are placed, later being hoisted aboard the launch and carried to Santa Barbara, from which place they are shipped to museums or zoölogical gardens all over the world.

On Santa Rosa Island, which is twenty miles or more in length, there are several rookeries where many sealions can be found in winter, and at San Nicolas, about eighty miles from San Pedro, there are a number. San Nicolas is a region of fierce storms, and to hear the roar of the sea-lions combined with that of the sea, to watch the flying clouds and wild waves piling in, is something I will long remember. We had tried several times to land here, and had been driven off time and again; but one morning we gained the long sandy spit that like a miniature Cape Cod is reaching out into the sea from San Nicolas. It was on the lee side, but a strong dangerous current was setting along 
the island, and the sea rushing in in big rollers from the west, while others came around the point of the island and joined them, making the landing particularly dangerous. On the rocky point we could see the lions, and their roars came in muffled notes as the wind swept over this deserted spot seemingly destined to go into the sea.

For some time we rode the breakers watching for an opportunity, and when the waves came in less menacing size we rowed in on the top of one, leaped over as the boat struck the beach, and dragged it up the sands. One man lived on this wind-swept place; and he was on the beach to meet us. Probably in all America there is not a more desolate spot, or a more windy one, yet here was a man, monarch of all he surveyed. He told us that he had built his home down among the rocks so that it would not be blown into the sea. I noticed great stones on the raof; these he said were to hold it down, as the wind was terrible. He also seemed to fear the sea-lions, and said that during heavy storms they came up around his hut and roared and barked.

This great rookery was on the south end of the island, low and rocky, and the herd was on the main beach. Some of the lions here were very large, especially the bulls, but they paid but little attention to us.

About forty miles south of San Nicolas lies the large island of San Clemente, twenty miles long. I found a number of rookeries here, with many sea-lions ; in nearly every instance in isolated places. 
At Santa Catalina the largest rookery of sea-lions is in the immediate vicinity of the best fishing ground, many kinds of fishes abounding within a few hundred feet of the place, and while the sea-lions are increasing there is never any discernible decrease in the fish supply. The greatest cause of complaint against the sealions comes from the net fishermen, who claim that they visit the nets with great regularity and take out the fish.

I observed this on several occasions. A sea-lion stationed itself near a net in the kelp, and every few minutes dived down and swam along the net, biting off the body of any fish that became gilled. This was done despite the fact that I was near the net in a boat, with the Italian owner, who hurled imprecations at the sealion when it came up from the net with a large rock bass in its mouth and deliberately tossed it into the air, as though to irritate the fisherman, who, while robbed in the grossest manner, was prevented by law from shooting the animals. No more interesting feature of wild life can be seen on the Pacific Coast than the sea-lion rookeries, and the ease and comfort with which one reaches them render the sport of bringing them down with the camera very enjoyable. 


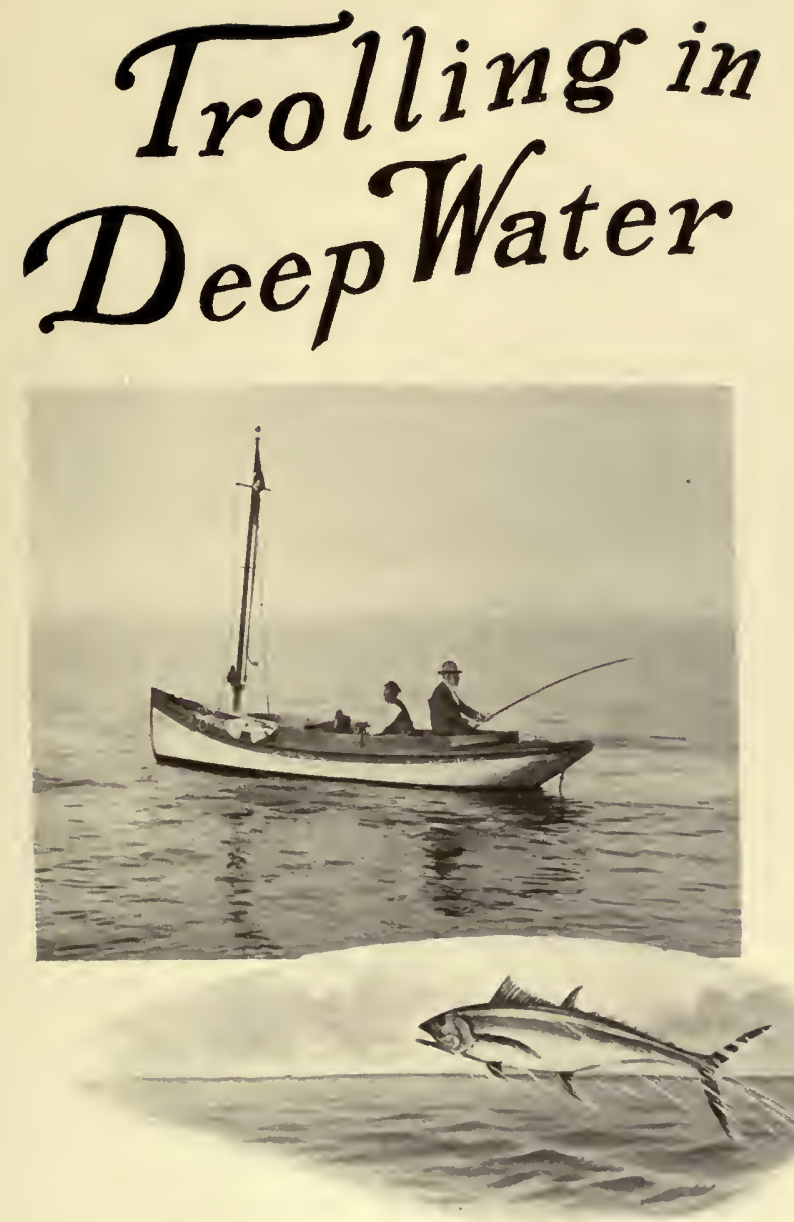



\section{Chapter XX}

\section{Trolling in Deep Water}

I sailing down the Santa Catalina Channel one may often meet several trim launches flying gay 1 flags, several miles off the bay of Avalon. The boats are models of comfort and utility; about twenty feet in length, with an eight-horse-power engine, and two seats astern and facing it for the anglers, whose rods point to port and starboard. The boatman is engineer, gaffer and steersman, and sits behind them as they cruise up and down the blue water, which may be a thousand or more feet deep and doubtless is.

The game here is the bonito and albacore, the latter a large mackerel-like fish allied to the bonito ; big-eyed, stout of body, coloured a rich blue, and provided with a pair of side fins that are so long they look like sabres hung to the side of this doughty swashbuckler of the sea.

The albacore is found here almost the entire year, preferring the channel, away from land, though I have taken it inshore along the kelp beds. The average 
catch weighs ten or fifteen pounds; and in the San Clemente Channel, to the west, albacores have been caught that weighed one hundred pounds and were doubtless the equal of any tuna of the same size.

Another albacore, ranking with the tuna as a game fish and weighing about fifty pounds, is the yellow-fin, or Japanese hirenaga (Sermo macropterus). This fish, common at Nagadaka, appeared at Santa Catalina in September of 1905 , affording rare sport; all the catches averaged fifty pounds.

The albacore is always on the move, and going fast ; it stands not on the order of going, but appears to be on the constant lookout for game or victims of some kind; hence it is easy game for the angler, who rigs his lure with a big smelt or a flying-fish, and moving fast has a continuous series of strikes-the fish making a very gamy play, though, like nearly all deep sea fish, inclined to sulk, although taken on the surface.

The most remarkable rod catch ever made in these waters was of albacore. The Avalon boatmen who took out anglers and looked on, but never fished, one day decided to go a-fishing; so they refused work and every launch went out with its owner and a friend in the seats, bound for the trolling ground offshore. They had agreed on the terms of the tournament, had prizes and cups, and at the end of the day about thirty rods reported about an average of ten albacores each ranging from ten to thirty pounds, the aggregate making a 


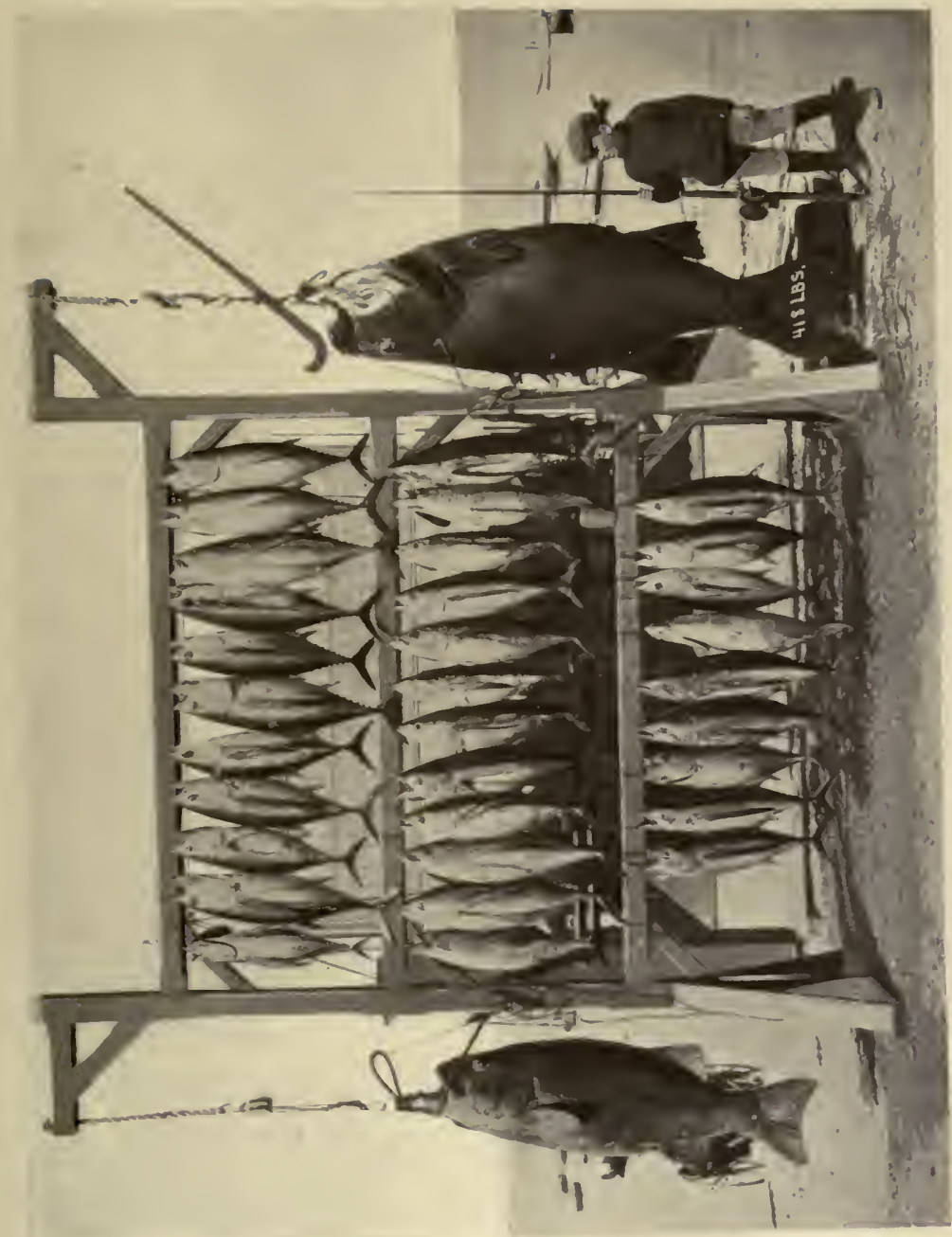

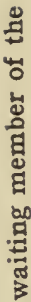





\section{Trolling in Deep Water}

remarkable display. The catch was given to the townspeople.

The boatman baits the line, and the launch moves on, now inshore, but still in deep water that is an intense blue to the very cliff, showing that the island is a mountain out at sea. The ocean is like glass, and so clear that the big leaves of olive-hued kelp can be seen, sixty feet or more below, slowly waving in the current.

We slack out forty feet of line and are watching the charming panorama of lofty cliffs and silvery gates to deep cañons which wind upward into the mountains, when $z e-e-e-e-e-e, w h-r-r-r-\gamma-r$ ! goes the line and reel, and something with fierce energy jerks the rod almost clear of the angler's grip. The novice turns pale, perhaps flushes, amazed at the ferocity of it all ; then rallies and gives the butt to one of the gamiest of all the fishes of the sea. Watch the marvellous play, the rush clear away of two hundred feet despite the play of the thumb on the heavy brake. Then it turns, comes swinging around in half a circle; now at the surface, now plunging deep into the blue of the channel to make the rod bend and groan.

Now he is gaining, reeling for life, the big multiplier (and it must be big to hold all the line this fish will take) eating up feet and yards as he reels and reels. Now it is away, a plunge into the sea, and the angler is forced to "pump" it up, raising the rod on high to drop it with a quick motion, reeling all the while, and gaining four or five feet at every effort, until finally a 
glint of silver and green is seen against the blue, and along the quarter, circling the boat, bearing off bravely; flashing in the sunlight, is a splendid bonito (Sarda chilensis).

Minutes have crept away, and twenty have been captured by the fish that, mad with fear, turns and plunges downward to the cry of the reel-ze-e-e-e-e! music that makes the watery welkin ring, sounds that stir the blood and flush the face. The rod and reel is plied deftly, and the game is brought to gaff. What a fish it is the boatman holds up! three feet long if an inch, with black stripes fore and aft ; blue or green on the upper side, silver below; and an eye of gold and blue, a gem in itself.

Twenty pounds is the verdict, and taken on a sixteen-thread line in just twenty minutes. Here is joy enough, one would think, but while the anglers are admiring the fine points of the fish, the other rod gives tongue, and a blare of sounds strikes the air, while the rod nods, bends, and swings up and down as though mad. Away go feet and yards, until the spool seems to be melting into the sea, and the boatman whispers, "Stop him, sir, or he'll get away with you altogether."

Stop him! aye, that's the question, but how ? You are pressing your right thumb on the line with all your force. Your hand is numb, and the rushing, grinding cord, a mere thread, is throwing a fine spray of powdered leather in every. direction. You press the line 


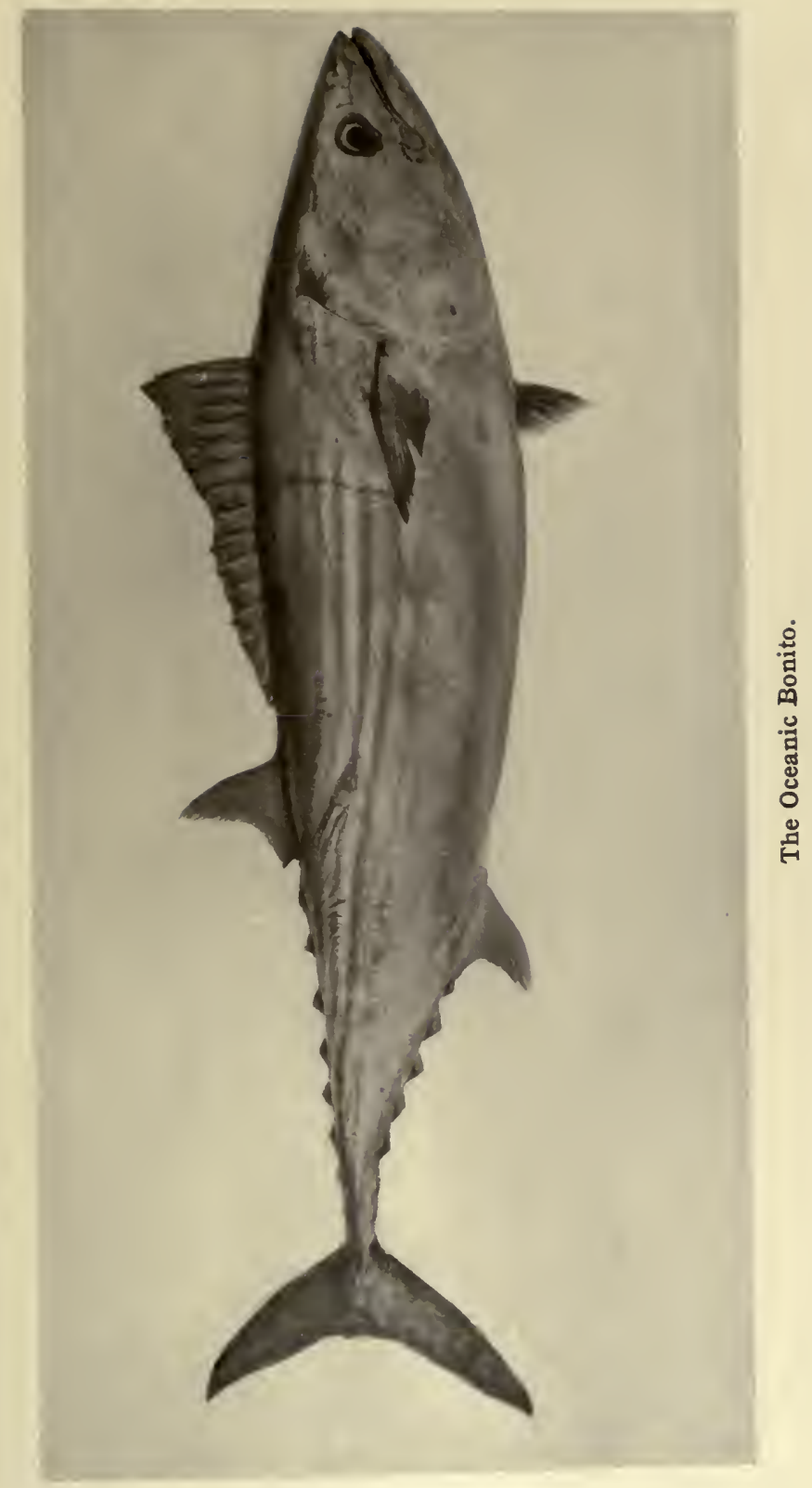





\section{Trolling in Deep Water}

upon the rod with the left hand and give the unknown the butt to the very danger point, until the rod creaks, groans, and threatens to buckle, and then the unexpected happens-the fish stops of its own accord; stops somewhere down in that blue abyss three hundred feet away, to turn and come bounding up.

All the tricks of the salt sea trade are his : circling, sounding, sulking, bravado; all are tried in turn. Every effort is made to break the line or rod, or take the angler unawares; but all to no purpose, and in fifteen minutes the gaff slips beneath it, and a fifteen-pound albacore (Sermo alalunga) is taken in "out of the wet," according to the boatman.

Out go the lines again, and in a few moments another bonito is hooked; this time the "skip-jack" (Gymnosarda pelamis), smaller, but quite as gamy as the large bonito. When taken from the water it is a veritable humming-bird in its beauty of colouring scintillating in iridescent tints of all kinds.

These fishes are ocean travellers, and found out around the islands nearly the entire year. Off Santa Cruz I have seen schools which fairly covered the surface for acres ; and from the Coronados, north and south, they are the common fish offshore, running with the albacores and tunas, all at times forming a devastating army ; charging the schools of flying-fishes, and in turn being chased by the orcas, or killers, that parade up and down the deep channel all summer.

There is a fascination about this fishing ground not 
hard to explain. The mainland shore is swept by the constantly prevailing west wind, and by ten or eleven o'clock, earlier or later as the case may be, it works up a sea that makes angling not always a pleasure; but to the south-west of Santa Catalina or San Clemente there is a lee, which extends many miles, in which the small launches can ply nearly every day in very smooth water, much like that of Lake Placid, the St. Lawrence, or some mountain stream; then if the wind springs up and comes down the channel, they can run inshore, where it is always calm, and still find good fishing. There is hardly a day that some one does not make a novel catch. It may be a giant sunfish, or a dolphin, the same beautiful fellow of many colours found on the Atlantic Coast, or it may be some rare fish from Hawaii, that has made its way around in the great current of Japan ; sword-fishes, the king of the herring, or opah, and many more make up the season's bag, with rod or spear.

The play of the albacore is much like that of the bonito, only harder, and is a revelation to the rod fisherman who has never taken large game, and I have known a fish weighing not over sixty-three pounds to tow a heavy boat and fight for two hours. 
The
California

WeakFish

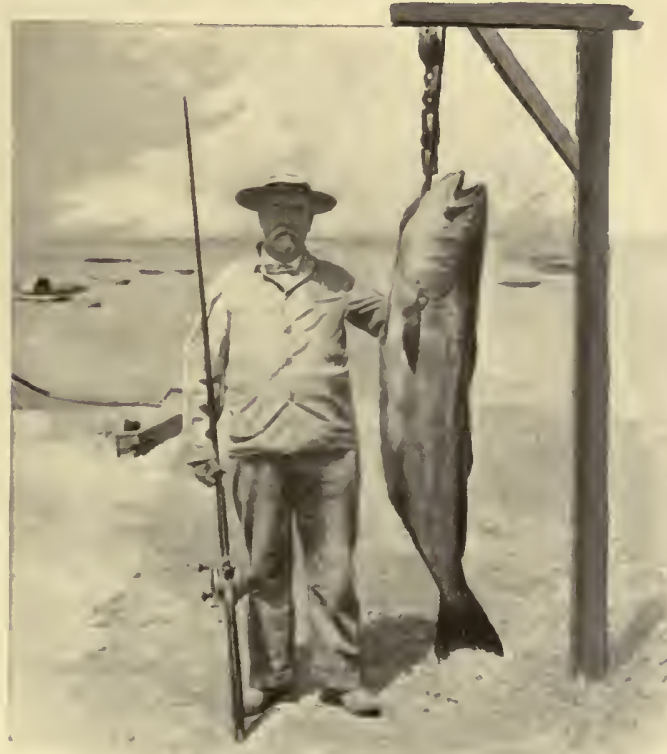





\section{Chapter XXI}

\section{The California Weakfish}

T $\mathrm{N}$ all probability more men go down New York Bay for weakfish than for any other denizen of the 1 shallow waters, and thousands have sat in the hot sun on the edge of the flats at the mouth of the river and felt well repaid with a four- or five-pound weakfish.

What would such an angler say to a fifty-pounder, not one but a dozen, or to see an eighty-pounder towing a boat across a placid bay? This can be seen in Southern California, or from the Gulf to San Francisco, as the Californians have a weakfish that is a giant, ranging up to one hundred pounds or more.

The fishes of the largest size are found in Lower California in the Gulf of California. I have been told of fine sport on the coast north of Tiburon, where the tide falls very low and comes in with a bore like that of Hang Chow or the Bay of Fundy. On the crest of this wave comes the white sea-bass, as it is called, a typical weakfish; and down in the Gulf it is taken by standing on the beach and casting into the surf, in which 
way fishes weighing one hundred and fifty pounds have been landed.

This is out of the world and on the edge of a desert, but the same fish comes in on the Californian coast in April and affords a short season. All those I have caught weighed over fifty pounds, this being about the average size of vast schools of the splendid game. Santa Catalina and San Clemente islands appear to be in the line of migration of the schools, and they are taken at Port Hartford and along the coast. They first appear, so far as known, at the south end of the island, and move slowly north, entering the bays and lying under the schools of sardines and smelt that congregate here. Thus large schools will enter Avalon Bay, Cabrillo, and others, and can be followed up as the fishes pass north.

I once ran into a large school at San Clemente Island, which is about fifty miles offshore. We were lying in a little bay when a ripple on the surface told of a large school of fishes of some kind, and pushing off we entered the largest school of bass I have ever seen. They were fishes of the largest size, and were so tame that they paid little or no attention to the boat. I could easily have grained or speared them.

We had some flying-fishes, and my oarsman hooking one on, I cast into the school thirty feet away. Down they dropped, then a whirl of flying water, a miniature maelstrom, and a fish had it. Here mark the difference between game of one kind and game of another. The 


\section{The California Weakfish}

fish seized the enormous bait and poised like a big barracuda, gulping and trying to swallow it. This occupied several seconds; then, when the gastronomical feat was an accomplished fact, it felt the slender wire leader and suspecting that something was wrong, turned and zeeee-zeee-zeee! sounded the click, like a blare of silver trumpets. One hundred, two hundred, three hundred feet of line went hissing, screaming from the reel before the rush was stopped, and then the fish came dashing around the boat in a great circle on the surface, presenting a fine spectacle of strength, beauty, and size.

There are those who do not care for large game-a fifty-pounder does not appeal to them,-and I confess that a four- or five-pound small-mouth black bass meets my fancy best; yet there is a fascination about taking a large fish; if this were not so it would not have passed into song and history that the largest fishes always escape. As I held my rod stiff and played gently upon the leather pad, mentally figuring on the chances, I half believed my fish was one of the "biggest" and would escape, as I was experimenting with a very fine line not equal to the task. The Chinese fisherman has an especial god for fishing. You may see it : a bunch of red firecracker-like paper, pinned to the cabin or its wall; and I fancy something of the kind was around about, as the particular saint that has charge of all anglers was very kind to me and I saved my catch. He made a brave fight and had I forced him the line and I would have parted company long before; but I handled him 
with care, gave line when he wished it very decidedly, played him with caution, and kept down what ebullition of spirits I might have had until the game was in the boat. For nearly an hour this gamy fish fought me, nearly always on the surface, gradually reaching offshore, coming to the gaff in a blaze of glory, and tossing the water and the spray over the boat in a last defiance. It was nearly five feet in length, an ocean peacock; its head ablaze with prismatic tints, its sides a rich grey, the belly silver, looking very much like a typical salmon and known to many anglers as the sea salmon; yet every inch a weakfish, and a fifty-pounder. ${ }^{1}$

It would be interesting to see such a fish played on a typical salmon rod, to try the relative qualities of the game. I do not know positively, but I fancy that the white sea-bass would wreck the salmon rod, or make the catch so long that the most patient angler would be wearied.

There is no more fascinating spectacle than a large school of bass swimming near the surface-types of dignity, strength, and reserve force; and the angler should never allow the opportunity to pass, as they are extremely fickle and the season a short one.

There is still another weakfish in Southern California, called the sea trout, that does not grow so large, found along the mainland shore where the larger bass are rare, evidently giving the surf a wide berth. 


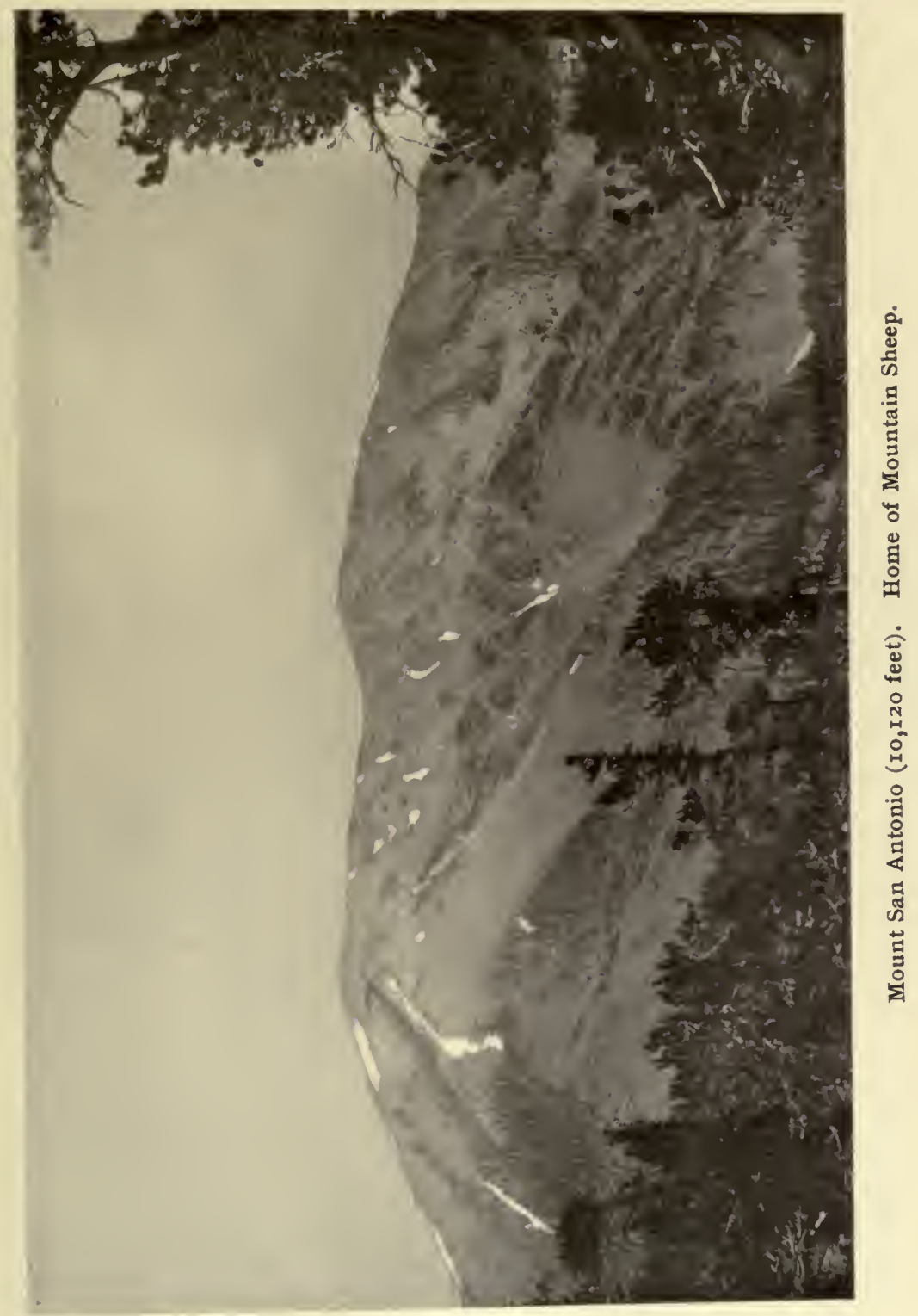





\section{The California Weakfish}

The young of the large bass are also called sea trout; gamy creatures rarely caught except in the gillnets of the professional fishermen. The latter have an interesting calling at the channel islands, but particularly in the Santa Catalina Channel, where all the market fishing of Los Angeles County is done. The men, mostly Italians, go out in their typical lateen-rigged boats and troll for the barracuda, that schools in these waters and constitutes a favourite market fish. With four or more hand lines boomed out, these boats sail up and down the channel and catch barracuda by the score.

Then there is the sand dab fisherman, who goes out three miles from Avalon to a sandy-bottomed country where he lowers a line three hundred feet down, with a dozen hooks on it, allowing it to remain for half an hour, then winding it up with a wheel. The catch, a little fish resembling a sole, is considered a feast for the gods.

Over in the San Clemente Channel we may see still another fisherman. He has a long trawl with several hundred hooks, which is set in six hundred feet of water, coming up with deep-sea groupers-strange, big-mouthed fishes of deep red and crimson tints.

With them come small sharks and various strange fishes, and enormous hammer-heads haunt the region, preying upon the groupers and other denizens of deep water. The gill-net and seine fishermen ply a profitable trade. The gill-nets are set at night out in the channel, and a variety of fishes are taken-Spanish mackerel, 
bonito, barracuda, flying-fish, and many more; and at times a thresher shark or a big tuna swims against the barricade. The former at once whirls over and over, involving the net in ruin, while the tuna dashes through, making a round hole. The seine is hauled in the surf on the mainland in various places, and surf fish, halibut, and others taken.

The surf fishes are particularly interesting, as they belong to a peculiar group in which the young are born alive. The latter, which I have kept in a tank, are most interesting little creatures, very tame, feeding from the hand, and schooling like sardines. No more interesting locality in which to fish and study fishes can be found than in the waters off the coast of Southern California, as it appears to be a sort of neutral zone where fishes meet from widely separated regions, from Hawaii to Mexico and beyond. It is also the breeding ground for many fishes, and the resort of countless wild sea roamers, as bonito, mackerel, tuna, sunfish, dolphin, and many more which can be found here in the various seasons. 

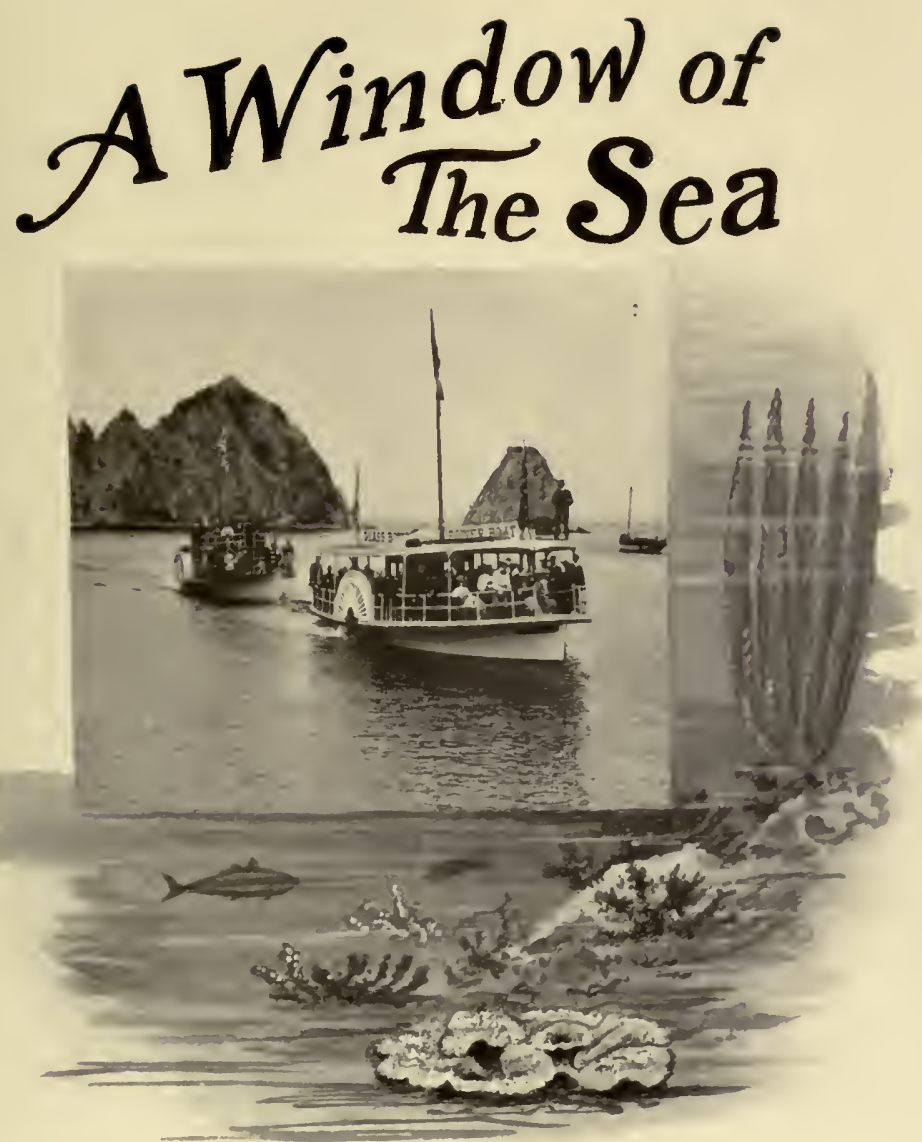



\section{Chapter XXII}

\section{A Window of the Sea}

T the old days of Roman supremacy it was the custom of epicures and gentlemen of cultivation and well ripened tastes to have the surmullet or the maigre served that day introduced on the splendidly appointed table in an aquarium, where its freshness was demonstrated beyond question to the assembled guests.

The angler can now go a-fishing in Avalon Bay, sit in the boat and fish while looking down through a window of the sea; not only see his game slightly magnified, but watch it take the lure in water from ten to fifty feet deep, thus observing what has nearly always been a mystery to the fisherman.

Where this pastime is possible, twenty miles out at sea, due to the clearness and absolute stillness of the water, a fleet of glass-bottom boats is found; ranging from a rowboat with a window for a single, or two anglers, to a steamer holding fifty or more passengers who drift over the kelp beds to enjoy the vistas of 
marine scenery and watch the myriads of strange animals seen there. The channel islands of Southern California are the tops of offshore Sierras, rising out of the sea; and could we see them divested of the ocean they would look like gigantic needles rising from the bottom. All have a peculiar beard or protecting growth of weed that constitutes a forest about them, a gigantic sea plant rising from water sixty or more feet in depth and forming a natural wave-break and a home for countless marine animals. The vines are often one hundred feet in length, vast cables with broad crimpled leaves of a rich dark olive hue, which assume graceful shapes in the tide, and when one peers down into the blue water the scene is often a revelation; a new world is opened up, and the real beauty of oceanic or submarine scenery is appreciated. The great leaves are carried by the fitful currents that sweep these islands in every direction. Sometimes they are extended at full length and appear like a horde of green snakes; again they lie at the surface, listless and drooping, forming myriads of halls, parterres, nooks and corners of much beauty, the real dark, unfathomed cave of the ocean.

So attractive are these kelpian forests, so fascinating to investigate, that the glass-bottom-boat voyages to them have become a pastime so well defined that thousands indulge in it, and the fleet with windows in the bottom cruises up and down the smooth waters, by the sea-lion rookeries, affording one of the most pleasing and novel experiences to be enjoyed on the Pacific Coast. 


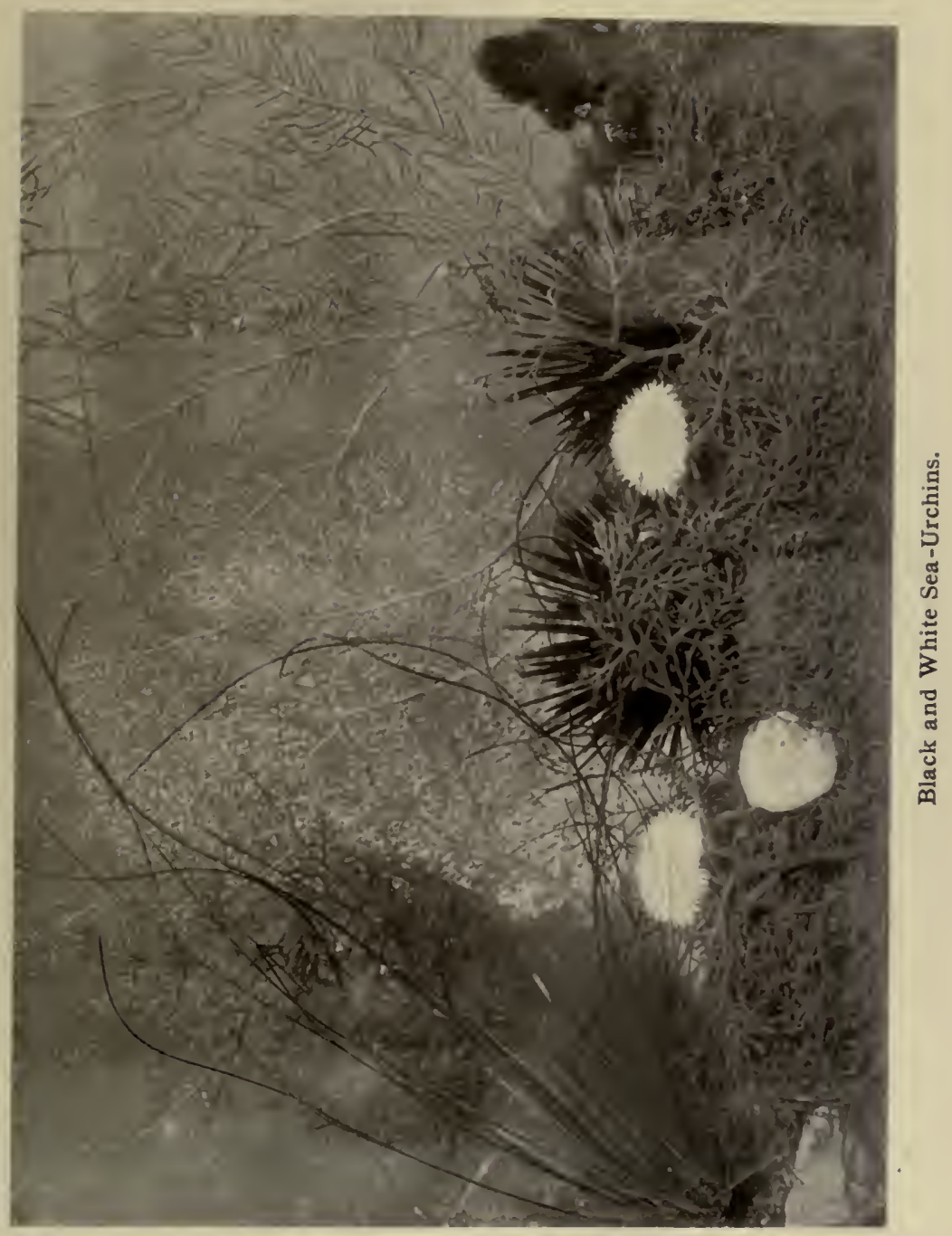





\section{A Window of the Sea}

At Avalon there are no hackmen; it is a sort of mountain Venice, where carriages are at a discount, except for mountain climbing. One takes a sea automobile, numbers of which lie in the bay, and the captains of the glass-bottom boats replace the hackmen of the mainland and cry the merits of their strange craft, each of which claims to the knowledge of some especially beautiful sea meadow or glade which he will take you over for the small sum of two bits.

These crafts are of all sizes and are significant of the attractions of the gardens of the sea, and doubtless the study of marine zoölogy never had more patrons than at this isle of summer where thousands of persons yearly make the safe and picturesque voyage.

The glass window in the boat is set in a few inches from the bottom so that when the boat grounds the glass does not. A large oblong well is built in the boat, its edges being padded; and about this from one to fifty observers can sit and gaze down at the passing throng a succession of ejaculations expressing the delight and satisfaction of the voyagers. The skipper of the craft discourses learnedly and always picturesquely on the strange creatures that pass in view. The captain of the glass-bottom boat is generally a character: amiable, courteous to a degree, replete with a marvellous, sometimes fearsome store of facts relating to the wonders of the deep, which he shares with his guests, affording a most interesting divertisement.

The voyager when the glass-bottom boat starts 
is first regaled with the sandy beach, in three or four feet of water. He sees the wave lines, the effect of waves on soft sand, the delicate shading of the bottom in grays innumerable; now the collar-like egg of a univalve or the sharp eye of a sole or halibut protruding from the sand. A school of smelt dart by, pursued by a bass; and as the water deepens bands of small fish, gleaming like silver, appear; then a black cormorant dashing after them, or perchance a sea-lion browsing on the bottom in pursuit of prey. Suddenly the light grows dimmer; quaint shadows appear on the bottom, and almost without warning the lookers on are in the depths of the kelpian forest.

The fitness of the term hanging gardens is apparent, as the great leaves appear to rise near the surface, then droop over, forming graceful arches and loops and conveying the impression of being suspended at the surface. The colour is a deep olive, grading to yellow ; the leaves a foot or more wide and very long; their edges crimpled. Each one is seen to be covered with a lacelike network of great beauty. Delicate plumes wave to and fro, telling of worms or minute sertularians. Here the tracery is white, like frosted silver, the limy deposit of some animal, while others are of rich lavender hues, all plainly seen as the great leaves are brushed across the glass window. The vagrant beams of light which strike the surface bring out the tints and shades in high relief. Through a green loop of kelp is seen the turquoise blue of deep water, and poised in it an 


\section{A Window of the Sea}

angel fish of vivid golden yellow, a tint that persists in taking black through the camera. A school of these fishes swims into view, turning their gorgeous shapes upward and eying the strange window in which are mirrored many faces. With them are smaller ones of a vivid blue iridescence, suggesting the strange vagaries of nature, as the very young are almost entirely blue, and called by our skipper "electric fishes." But as they grow the blue merges into orange, and the adult fish blooms out in its perfect coat of gold.

On the leaves are seen singular crabs, red and olive, with square shells, and deeper in the crevices of the moss-covered rock are gigantic spider crabs a foot across, mimicking the rocks in shape and colour. The nature of the forest is ever changing. Now great pompons of a rich dark weed appear, in splendid tints, born of the deep sea. It waves gracefully as the slight swell comes in, and as it turns aside displays the very giant of the star-fishes, a huge creature garbed in red, with white spikes or tubercles scattered over it, a most conspicuous object among the greens. The star-fish is twelve inches across, and slowly moves along by the aid of its myriad feet. In the crevices are smaller stars ; some a vivid red, others dark, with arms like snakes.

The bottom changes now to a finer moss or weed, a deep velvet green here or there, changing to iridescent tints ; and in it lie big, slug-like, brick-red sea-cucumbers ; and then-presto ! the captain of the glass-bottom boat transports us to a deep glen in which lacelike plants 
rise and poise - a tracery of ineffable delicacy and beauty, forming a natural canopy for numbers of longspined black echini, or sea-urchins; formidable creatures, sea-porcupines, that recognise the presence of some possible enemy, and attempt to hide by plunging deeper into the maze. Splashes of white tell of a white sea-urchin, and almost every nook and corner of this sea-forest is inhabited by these aggressive creatures.

The bottom of the sea along this rocky shore is a colour scheme of marvellous beauty. Green is the predominating hue, but green in countless shades, tones, and expressions. Sometimes a short wiry weed covers the bottom, but it is constantly being waved aside to display other and more beautiful colours : weeds in purple, brown, rocks of lavender encrusted with a flaming red sponge or a mass of pink serpulæ, from which rises the delicate mauve tracery of their breathing organs. This sea tapestry is constantly in motion, so has the appearance of changing light and shade, tint and colour, every moment displaying some new creature to the voyagers of the curious craft with windows looking down into the sea.

As it glides along, the bottom seemingly slipping away, a strange pointed snakelike head appears, projecting from the algae. It turns, glides forward with a singular motion, and displays itself; an eel or moray, four feet or more in length and proportionately robust. It is a dark brown colour, spotted here and there with yellow, and should it open 


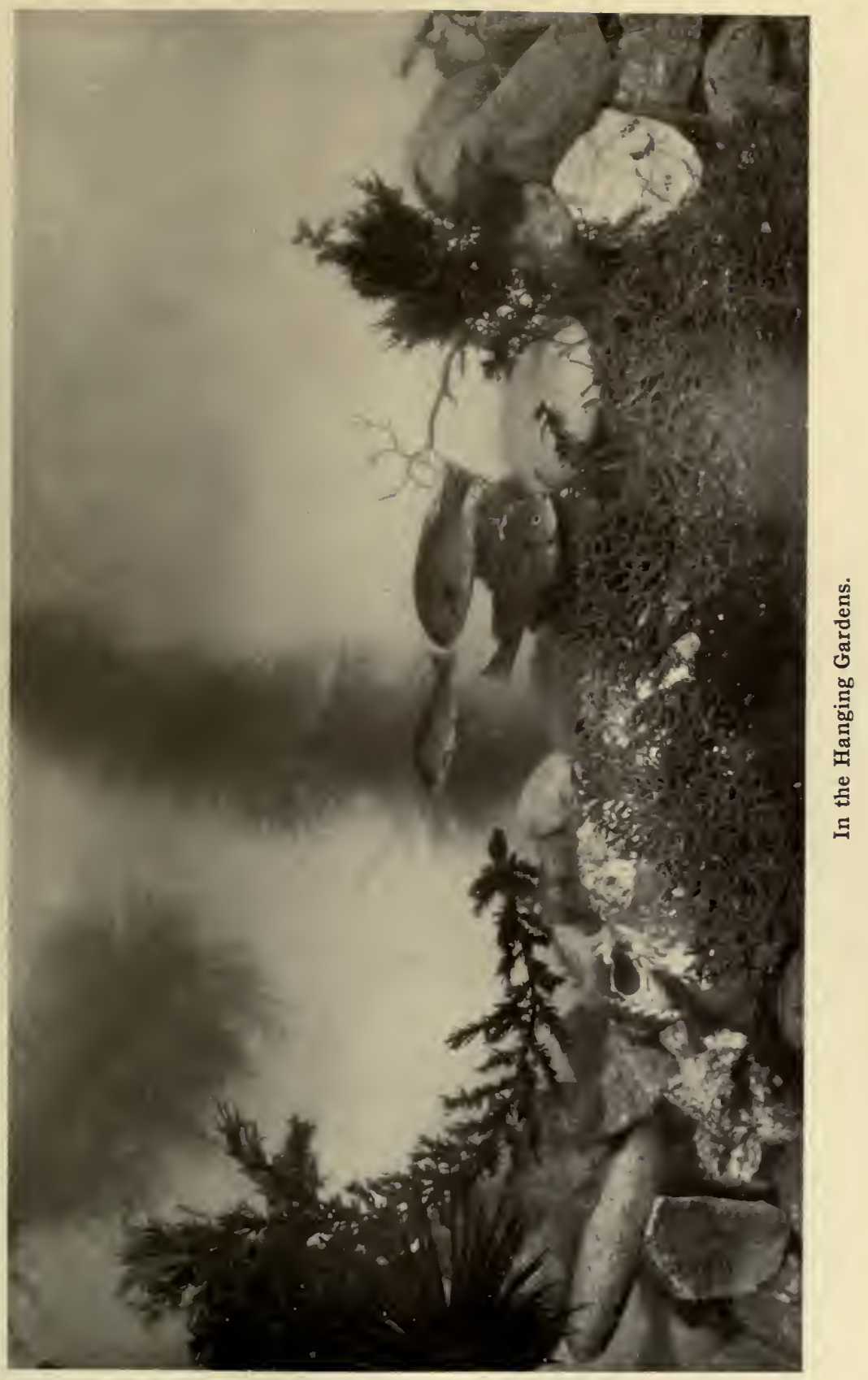





\section{A Window of the Sea}

its mouth it would display menacing fanglike teeth.

The glass window is now poised over a group of forms which must be the flowers of this marine forest. They are gigantic sea-anemones, four or five inches across and several tall, while radiating from the circumference are innumerable mauve and purple petals which give the lowly animal, a cousin of the corals, a startling resemblance to a Burbank daisy, or some large flower of that class. Some are fully expanded, standing firm and erect; others are closed, the petals drawn in so that they appear to be mere mounds of mauve on the rocks. Near them are true corals, which appear to be anemones, the delicate pellucid tentacles rising above the limy tube. Moving offshore, huge comet-like jellies may be seen, twenty to thirty feet in length, with dark lavender markings, or more delicate and fairy-like living traceries drifting in the current, standing out against the deep blue of the sea. Large fishes poise in the lower depths, the large sea-bass mimicking the folds of the great kelpian forest that rolls and sways above them in the current.

Nature is a very clever masquerader, and has apparently so bedecked several large fishes that they find abundant protection in the resemblance to the crimpled leaves of the kelp. None of the lookers-on can see the kelp-fish which the skipper assures them is directly before their eyes. But suddenly the leaf, or what they thought was a leaf, stirs, unbends, and resolves itself 
into a fish, marvellous in its resemblance to the leaves among which it lives. The mimic is a foot in length, of a delicate green, tending to yellow, the exact tint of the kelp, even the paler whitish spots being simulated; not only this, but the kelp-fish poises in the hanging gardens either on its head or tail, or partly recumbent, so that it has assumed the exact position of the leaves it so closely imitates. It is long, slender, with a high fin extending its entire length; a pointed mouth, and eyes having the strange faculty of following one around, after the fashion of the eyes of old portraits.

The window drifts past a slug-like animal lying on painted rocks, the bêche de mer of the Chinese, in which lives the strange glass-like fish fierasfer. Here is a colony of mimic flowers, serpulæ, with crowns of red, blue, and seeming gold. The lightest jar on the boat and they are gone, to appear slowly unfolding like flowers. Near them are other tube-building worms, with similar organs; and out from beneath a richly-coloured rock wave the "whips" of the spiny lobster or crawfish -a lobster in all but the large claws.

The animals of the hanging gardens are not confined to the kelp or to the rocks of the bottom. The blue water where the sunlight enters brings out myriads of delicate forms, poising, drifting, swimming, the veritable gems of the sea. Some are red as the ruby; others blue like sapphire; some yellow, white, brown, or emitting vivid flashes of seeming phosphorescent light. Ocean sapphires they are called; the true gems of the 


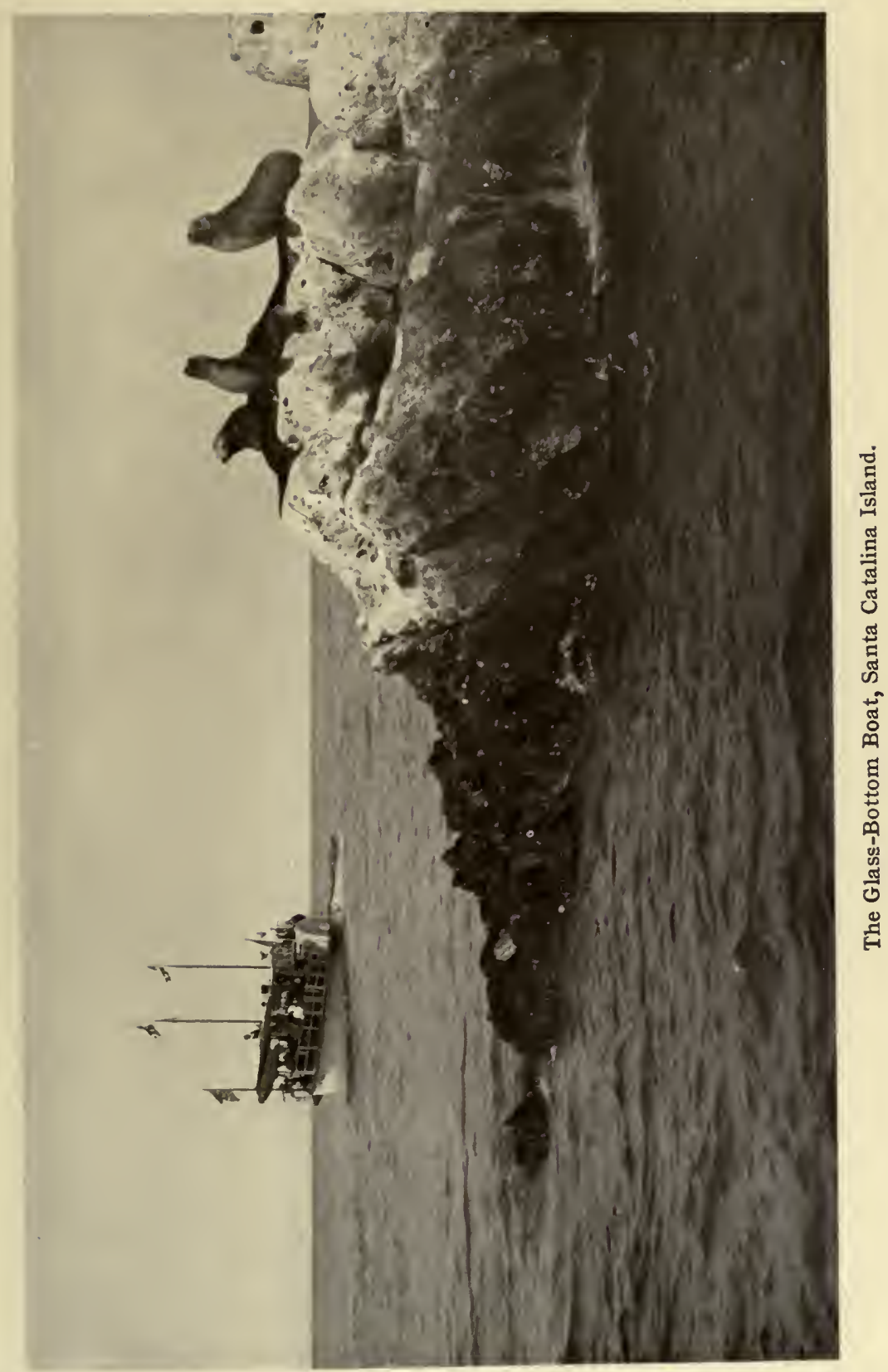





\section{A Window of the Sea}

sea, thickly strewn in the deep blue water. Sweeping by, poised in classic shapes, are the smaller jelly-fishes; crystal vases, so delicate that the rich tone of the ocean can be seen through them, changing to a steely blue. Some are mere spectres, a tracery of lace; others rich in colours and flaunting long trains.

Nearly all these pellucid crafts move by slow flapping of the umbrella-like disk; but here is a jelly, the Physophora, which has a series of pumps by which it shoots along through the water. No more beautiful object can be conceived than this; ablaze with colourspink, white, blue, and quicksilver; darting through the azure waters that form the atmosphere of the floating garden.

As the boat moves out into deep water the purity of this aqueous sky is seen, as fifty feet below the rocks are plainly visible, and the dim shapes of kelp leaves faintly outlined far beyond. Here large fishes float: the graceful sheep's-head, peculiar to the region, the male having enormous red and black stripes, a blunt forehead, and the lower jaw of pure white. The female is a radiant creature, with beautiful eyes, and often red, brown, or white. These fishes are easily attracted to the boat by a judicious display of bait, where their graceful forms can be plainly observed.

Now the window is over deep water, to see the passing school of barracuda: tens of thousands of long, slender, pike-shaped fishes, all headed in one direction, swimming slowly, a picture of a thousand staring black 
eyes dotting the sea. Suddenly they disappear, as though some shutter had been snapped, and into the field dash a school of large sea-bass, the splendid game fish of this region. Again the window approaches shoal water, and for several miles it follows along this fishes' highway, providing the voyagers with an ever-changing panorama of marine scenery. Now it will be a shoal of blue perch, a fish that affects the kelp forest and presents a sharp contrast to it in its vivid tint.

These fish like to bask and sport near the surface, and the window appears full of them as it moves along. Rock bass, singly and in schools, are seen poised in alcoves of the kelp, richly striped brown and black; and here the radiant "white" fish, as blue as the water, with long and beautiful fins, while in the depths below other and interesting forms are seen, all slightly magnified by the glass.

In and out, now in shallows where the velvet-like rocks are near the surface, now offshore, following in the trail of some vagrant shark, the shallow steamer moves, affording strange vistas of the sea and its secrets, and emphasising the fact that a new method of study has been found in the field of popular science that is at once a pastime and recreation. 


\section{Gruisinglimong \\ Channel Islands}

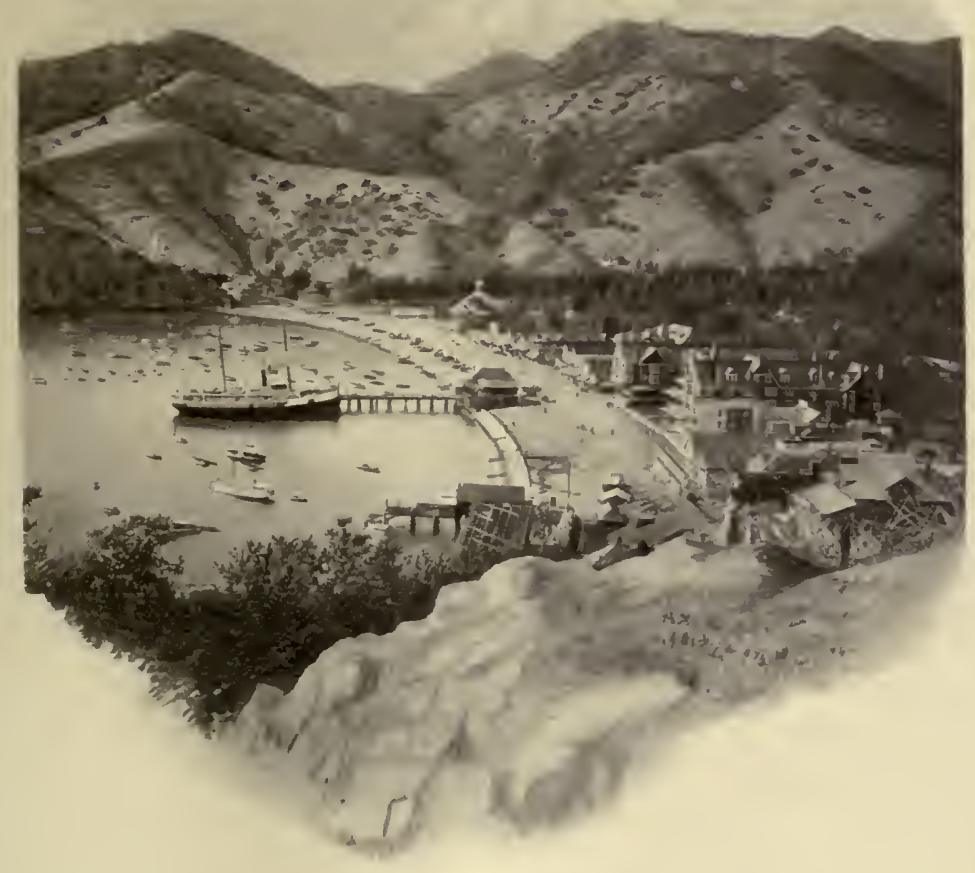





\section{Chapter XXIII}

\section{Cruising Along the Channel Islands}

TRUNG along the coast of Southern California are several groups of islands: the Coronados of San Diego, the Santa Catalina group, off Los Angeles County, and the Santa Barbara Islands, opposite the Santa Ynez Mountains, that rise in graceful lines over the old Spanish town, one of the few in Southern California still possessing strong individuality.

The Coronados are small, and have no permanent residents. The Santa Catalina group consists of four islands : Santa Catalina, eighteen miles offshore, twenty-two miles long and sixty around; Santa Barbara Rock, twenty-five miles north; San Nicolas, eighty miles out at sea, to the north-west, and San Clemente, nearly as large as Santa Catalina, forty miles to the south-west from the mainland. The Santa Barbara Islands lie on the channel of that name, about twenty miles offshore, and are four in number: Anacapa, Santa Cruz, Santa Rosa, and San Miguel, all but the former being of large size. 
Nearly all these islands are peaks of an offshore coast range, thrust up here ages ago, and we can imagine them lofty isolated peaks rising from a ridge that doubtless runs along shore far to the south.

Only one of these groups, Santa Catalina, has a permanent settlement, the town of Avalon. This is the only inhabited island open to the public and having regular daily boats. Avalon is a fully-fledged and wellequipped community, with hotels, cottages, homes, and what is without question the finest rod fishing for large game fishes in the world. This and its singularly perfect climate have given Santa Catalina a wide reputation.

The town stands on a miniature crescent-shaped bay from which a deep cañon reaches away, stopped by a mountain range two miles to the west. The vale of Avalon is a romantic and beautiful amphitheatre, surrounded by ranges of hills which rise one above the other in a jumble of peaks. In winter it is green, a marvellous contrast to the deep blue of the sea, in which the island rests in peace and tranquillity, almost the only object that is "pacific" in this sea of Balboa. The harbour of Avalon is a miniature Naples, and the climate is so singular that from April to November, and often December, a storm or squall of any kind is unknown. Nearly every day there is a stiff breeze a short distance out, but along the rocky coast, near shore, the high mountains ranging up to twenty-two hundred feet produce a lee so that small boats are perfectly safe. 


\section{Cruising Along the Channel Islands 33r}

Twenty miles out to sea, the island is perforce a yachting centre, and the only port in Southern California, except Santa Barbara, San Pedro and San Diego, where there is an exensive boating and sailing contingent, safe at all times; and the little bay is filled with craft of all kinds, racing auto boats, fleets of glass-bottom boats, while launches extend out from every boatman's stand, filling the south end of the beautiful bay and forming an attractive colour scheme.

Here is often the rendezvous of the South Coast Yacht Club. The yachts cruise among the islands, San Clemente, twenty miles distant, being an interesting point for its fine fishing and the fact that, like all the islands, it had at one time a large and vigorous native population whose strange implements are found buried in the shifting sand dunes that are constantly changing shapes. San Clemente is government property, and is rented to sheep herders, from whom permission must be had before landing.

An interesting cruise can be made to San Nicolas, about eighty miles from Avalon. The island is in the region of eternal winds. I made three attempts to reach it in a sixty-ton yacht, each time being driven back by heavy winds, or having to lay to in the heavy sea. Approaching it, the island is seen to be low-lying, about seven miles long, with mountains or hills in the centre, and over it a cloud bank that is bombarded by the wind, which apparently is never quite able to drive it off. To the east a long sandy spit reaches out, 


\section{Life in the Open}

and by this we anchored in a treacherous sea, the tide rushing up and down, the sea running in and around, and the wind whistling a mournful dirge through the rigging.

The landing is through the surf, and dangerous. Another anchorage is at Corral Harbour, several miles above. The wind-gods hold San Nicolas, and a more uninviting spot it would be difficult to find. The wind seemingly never ceases, lifting the sand into the air, whirling it along like wraiths, filling great cañons, emptying others, and every day changing the landscape. I crossed a plain as level as a floor, covered with small pebbles that at times the wind hurls through the air. Despite its interesting features, San Nicolas is a good place to leave behind. In 1836 , we are told, the last Indians were taken away; but as they were leaving a squaw swam back to get her child, and for some reason was left and abandoned. In I856, twenty years later, George Nidever of Santa Barbara landed there, on an otter hunt. To his surprise he found huts of whalebone, and near one an old woman, dressed in a garb of skins and feathers. She presented a weird appearance; her language was unintelligible. Nidever took her to Santa Barbara, where every attempt was made to find some one who could talk to her, but without success. The "lost woman" died three months after her rescue, and was buried by the mission fathers.

In striking contrast are the Santa Barbara Islands, 


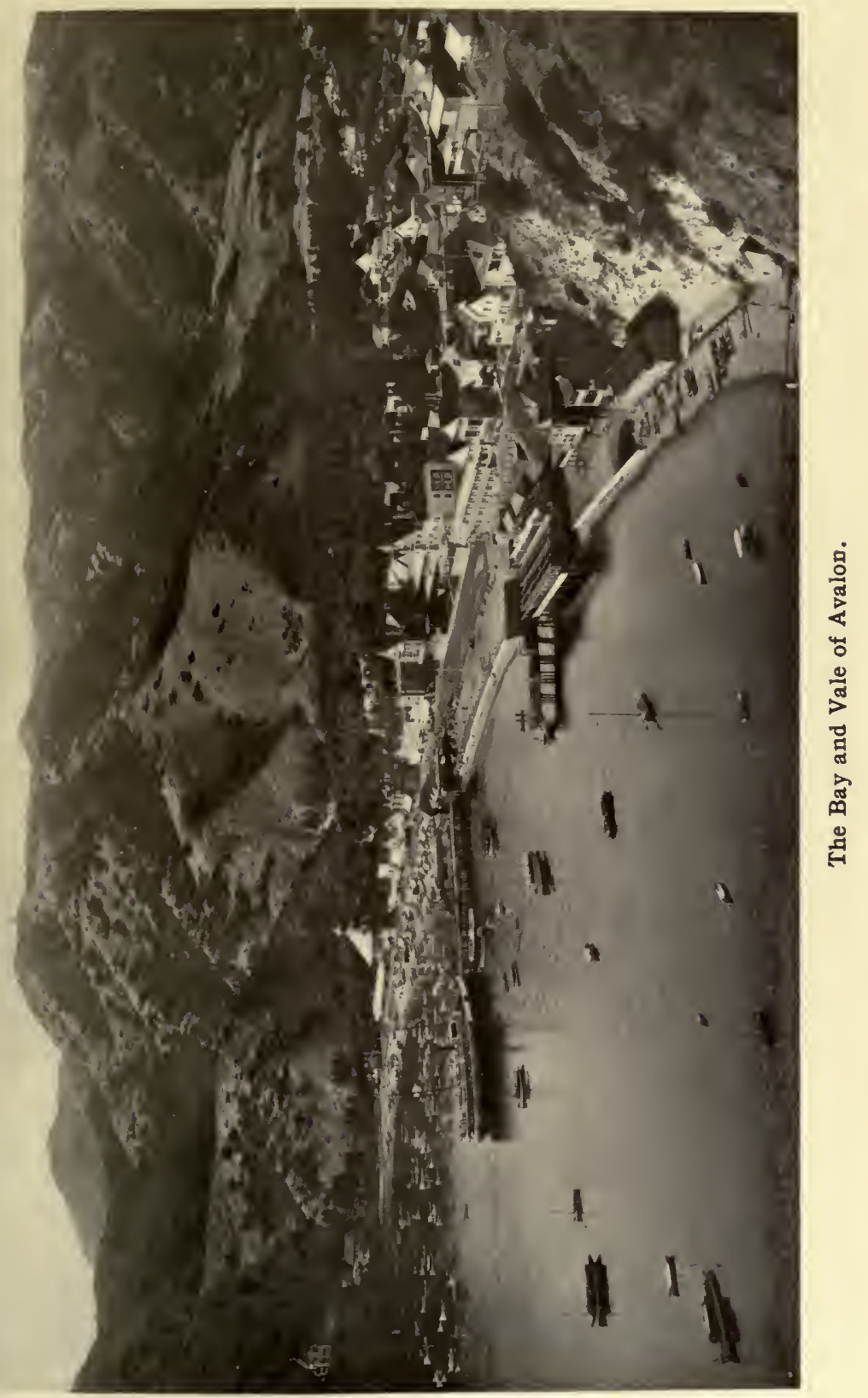





\section{Cruisiug Along the Channel Islands 333}

about one hundred miles north of Santa Catalina. The winds are often heavy for a small boat here, and for perfect comfort and safety a commodious yacht is needed. Anacapa lies to the south, a long rocky spit, changing at every point of view. Over a small channel lies Santa Cruz Island, nearly as large as Santa Catalina, well wooded, hilly, and very attractive, in the interior of which is a vineyard, the property, as is the entire island, of a Swiss-Italian wine colony. The interior is reached up a narrow but beautiful oak-lined cañon-the bed of a stream winding upward and leading into the little valley of grapes. The harbours at Santa Cruz are more or less open, but good anchorage is to be had, and strong winds for sailing are met with every day.

Santa Rosa lies farther out, and is a large island used as a sheep and cattle ranch. Portions of San Miguel, which lies to the north, it may be said, are being blown into the sea. With San Nicolas it represents the undoing of an island, and the view of white sand dunes flowing over mountains is an interesting phenomenon, and the island is worth visiting if for nothing else than to witness the vagaries of the winds which come in from the west and toss the sand aloft where clouds and wraiths go whirling through the air, borne upward to drop like snow upon the waters. Three hundred years ago this island was discovered by Cabrillo, the Spanish adventurer, who died and was buried here. At that time the island, it is said, was covered with verdure, trees and brush, 
as are parts of it to-day; but the sand in the course of years has encroached upon it and reduced the former productive portions to the state of a mere desert, and to-day it presents a most desolate appearance, and those who land here have to wade through the deep sand that is ever piling up and is destined to completely fill the harbour or reduce it to a shallow.

Some time ago a schooner was thrown ashore on the beach, and-to show the remarkable movementof the sand-the vessel is now some distance inland and nearly buried out of sight by the insidious advance. It has covered the deck, run down into the hold, partly filled the craft, so that from a distance she appears to be riding on a sea of sand, hard pressed and desolate. All about, as far as the eye can reach, sand is coming down the hills or going up, covering the rocks and gullies, sweeping into cañons and forming vast slides by which one can slide from the summit of a hill fairly into the bay.

As a picture of desolation and the rapid movement of sand, San Miguel has no equal. It works like snow, the slightest obstacle being an excuse for piling up; and along the beach are seen a succession of sand waves, so high in some instances that the stroller is lost to sight as he moves slowly along. There is no better place than this great amphitheatre of sand in which to observe the action of the wind, which at one point carries it up a steep slope, and not far away it is pouring down.

The advance of sand is often subtle and unobserved; 


\section{Cruising Along the Channel Islands 335}

even when the wind is low it is moving, and by lying down on the dune it can be seen coming along the surface in well-defined rivers. I noticed this particularly on the outer islands of the Texan coast, where the sand rivers in numbers of instances were blowing a distance of a mile or more from the gulf across the flat to the inner bay. They moved at about the same rate of speed that a man would walk, and were incessant, and had been for centuries; yet the island retained about the same shape, the loss of sand being equal to the supply. The prevailing wind at San Miguel is north-west, and wing and wing we fell away before it, leaving the inhospitable shores to make the harbour of Santa Barbara with its splendid beach and tiers of houses rising one above the other to the mountains of Santa Ynez. Yachting ${ }^{1}$ is a delightful diversion in Southern California, and between the various resorts from Santa Barbara to Coronado, or to San Diego, and the attractive and beautiful islands offshore, the yachtsman has ample choice.

The climatic features of Southern California lend themselves to produce very favourable conditions for yachting. During the entire season, from May until November, there will be no storms, squalls, cyclones, thunder-storms, rain, or any of the conditions that hold on the Atlantic Coast. Every day there is a west wind that can be counted on, sometimes strong, sometimes

\footnotetext{
${ }^{1}$ None of the habitable islands of Southern California are open to the public except Santa Catalina; but permission to land can doubtless be obtained from owners or lessees.
} 
light, and always cool and delightful. Pasms fringe the shore at Santa Barbara and are seen everywhere, but it is never hot in a tropical sense; there is rarely uncomfortable weather in port or out to sea.

The lee of the large islands often produces a dead calm, and for this reason auxiliary yachts are popular, being able to go into the nooks and corners of the coast. All summer there is a delightful, fresh, stiff breeze; heavier in the Santa Barbara Channel, lighter off Santa Catalina, and lighter still between San Diego and the Coronados. As summer wanes and September comes, the wind all along shore dies down, diminishes in force, but the same delightful conditions hold far into the fall. In twenty years' familiarity with the sea here, I have never run into a day fog similar to that which drifts inshore off the New England coast. The fog is always high during the day along the Santa Catalina Channel. The heavy bank can be seen offshore to the west, oftentimes stationary, holding its own by some mystic power against a ten-knot breeze; but at about five o'clock in the afternoon it will begin to move in, as clouds, from four to eight hundred feet up, coming inshore in long lines, creeping up the river beds, as the Santa Ana and San Gabriel, following along the Santa Ana and Sierra Santa Monica ranges and filling the valleys; but out at sea it is clear. The high fog of Southern California nights and days is one of its blessings.

The winter season is equally delightful for yachting. All the islands are then rich in greens, literal wild-flower 


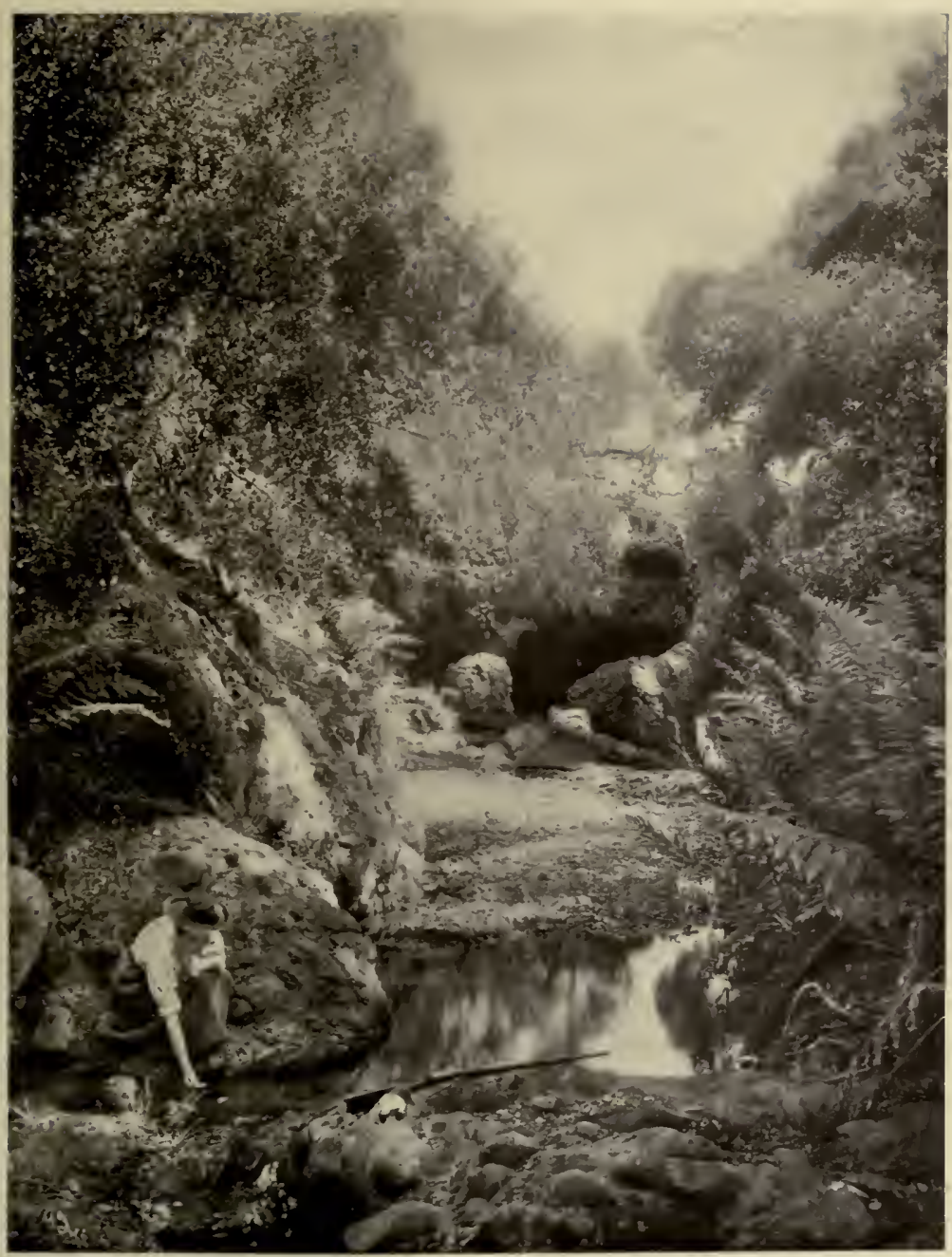

Fern Cañon, Santa Cruz Island. 



\section{Cruising Along the Channel Islands 337}

gardens in the sea, with a most interesting flora. Professor T. F. Brandegee, of the California Academy of Sciences, says : "It has been suggested that these islands are the remnants of a western Atlantis. The botanical arguments in favour of the theory are drawn principally from the flora of the island of Santa Cruz, and consist mainly of new species." The list of plants, according to this authority, includes about five hundred and twelve species, twenty-six of which have not been found on the mainland, and only twelve of the latter being known on the islands of Lower California.

Among the interesting plants to be seen here are Catalina dogwoods, five-leaved oaks, the rare MacDonald's oak, and a yellow Heteromeles. At Christmas time this island is ablaze with colour, the beautiful red berries of the holly, or Heteromeles, being seen everywhere. Over the slopes, with Adenostoma in vivid green, is the Catalina apple, Crossosoma californicum; not an apple at all, but a bush about fifteen feet high, which looks very much like it.

Here blooms the Malva rosa, the wild lilac, while the glossy and delicate green of the wild cherry flashes in many cañons, a contrast against the deeper greens of ironwood. The silver tree, Eriogonum, is seen along the slopes, while later a fringe of radiant blossoms in clusters depends along the edges of lofty cliffs, telling of zephtosyne.

The island-and I take it as a type, as it is the only one available to the public by daily boats-seems filled 
with rivers of verdure flowing in all directions, and in winter the vale of Avalon becomes a charming picture with its setting of green hills which might well delight the eye of artist or poet. In January, February, and March, wild flowers follow in rapid succession over the hills and dales, and the days are like the cool days of the late eastern fall. Perhaps the most remarkable feature is the dryness of this island, twenty miles out at sea. The relative humidity for the year is $67^{\circ}$; that of Asheville, N. C., is $72^{\circ}$; Jacksonville, $70^{\circ}$; Philadelphia, $80^{\circ}$. The average heat for July at Avalon is $65^{\circ}$. In August, I892, a typical year, the highest mean temperature at six in the morning was $72^{\circ}$, the lowest $68^{\circ}$; the highest at noon $78^{\circ}$, the lowest $69^{\circ}$. The highest at six in the evening was $74^{\circ}$, the lowest $68^{\circ}$; the lowest ocean temperature was $69^{\circ}$ at six in the morning, the highest $76^{\circ}$ at noon. Frost is practically unknown at Avalon. The comparative mean temperature for the six cold months is $58^{\circ}$; the average for the same period at Nice in southern France is $48^{\circ}$, or $10^{\circ}$ colder, yet Nice is the most famous health resort along the Riviera. The average temperature for January at this island is $54^{\circ}$, making the difference between mid-winter and mid-summer $\mathrm{II}^{\circ}$; a most remarkable feature, which I wish to emphasise, as it shows that the vale of Avalon has an almost perfect climate, of interest to those who desire such conditions and propose cruising along the Pacific Coast. For these figures I am indebted to Mr. H. Elms of Avalon, who kept the records for six or seven years. 


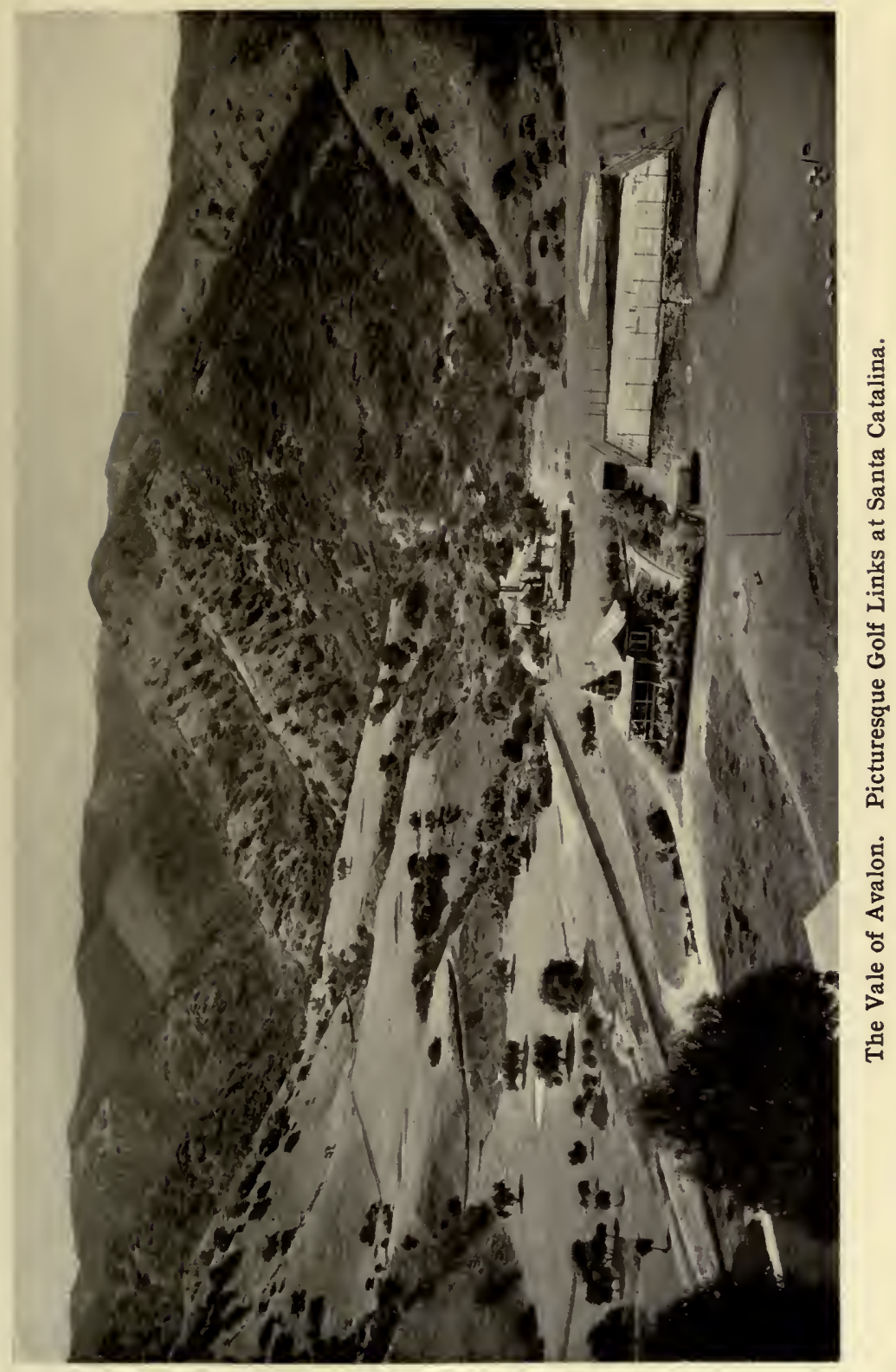





\section{Cruising Along the Channel Islands 339}

The resorts of the world famous for "perfect climate" are those in France and Italy along the Riviera, visited by thousands of Americans who travel across seas and continents in search of a mild climate, not realising that in three and one half or four days they can reach from New York an American Riviera, the coast line of Southern California, far surpassing any locality in Europe in its climatic perfections. To emphasise this the following table may be referred toshowing the difference between the monthly mean temperature of the resorts of the European Riviera and Southen California, January and July:

\begin{tabular}{|c|c|}
\hline ome, Ita & Nice, France... \\
\hline Naples, " ... & Cairo, Egypt \\
\hline acksonville, Fla. & $\cdots 33^{\circ}$ \\
\hline ad, N. Z ..... $19^{\circ}$ & Avalon, Cal........ \\
\hline pronado, Cal. . & arbara, Cal. \\
\hline
\end{tabular}

No records are available as to the islands of San Clemente, Santa Cruz, and Santa Rosa, but doubtless very similar conditions hold, as the climate from Santa Barbara to Coronado, including the near-shore islands, is as near perfect as can be found, being invariably milder than the interior.

In cruising among the channel islands in winter, the yachtsman will occasionally experience north-westers and south-easters, but the rule is a succession of clear and beautiful days. Santa Catalina Island has a good harbour in Avalon except when a south-easter blows; 
then the land-locked Catalina Harbour affords perfect anchorage. The new breakwater at San Pedro has made a harbour for the navies of the world, while the inner harbour is where yachts winter. Terminal Island has no harbour, relying on the protection afforded by the San Pedro breakwater; but here in summer many races are held. Off Coronado is the course of the Corinthian and the San Diego Yacht Clubs, the inner harbour being one of the finest in the world, with an ideal climate winter and summer. Here are held the yearly contests for the Lipton Cup, a splendid trophy presented to the former club by ${ }^{\circ}$ Sir Thomas Lipton. The race is often entered by yachts from the northern clubs. Nowhere in America are the conditions so nearly perfect for this sport as along the coast of South. ern California, especially among the channel islands, where the long, cool summer days imperceptibly melt into winter that is still summer under another name. 


\section{The \\ Stillfingler}

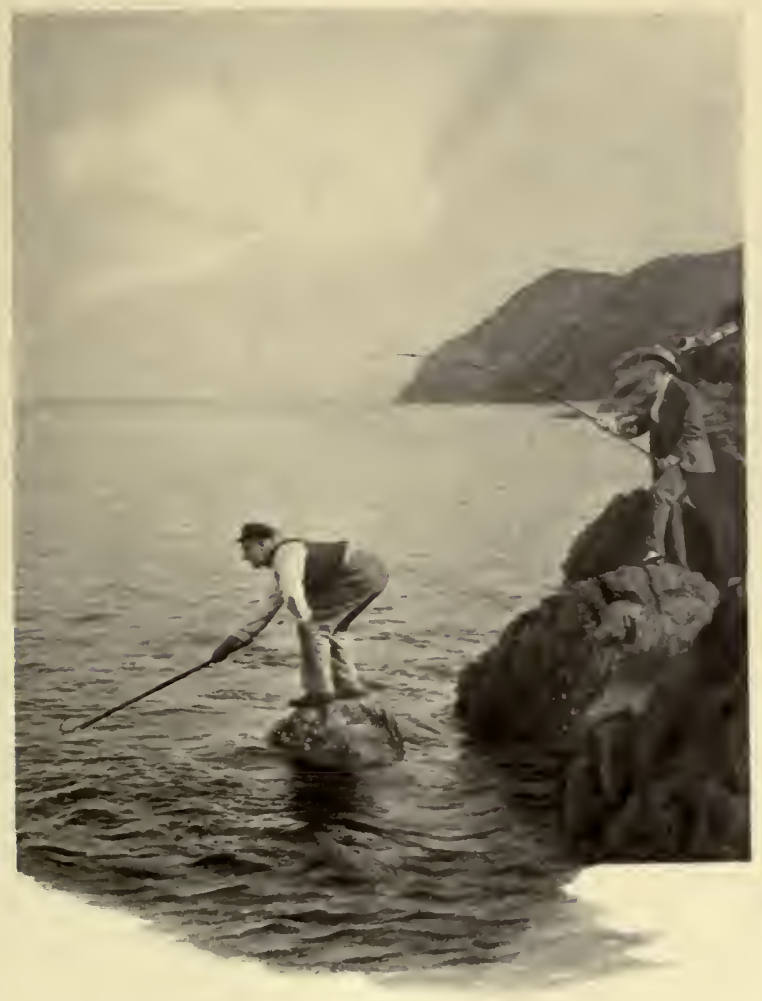





\section{Chapter XXIV}

\section{The Still Angler}

NE would look a long way along the New England coast, or possibly anywhere else, to find a municipality that would spend thousands of dollars in extending one or more splendid piers out into the sea for the sole benefit of anglers who might come that way; yet nearly every Southern California town on the sea-shore has such a pier, or several; not makeshifts, but fine affairs, leading out over and beyond the breakers, and in the main for the fisherman, the still angler, the philosopher of content, who comes from the interior and the East and fishes from the stringpiece to his heart's desire.

These begin at Santa Monica, and reach to San Diego, where a long pier reaches out from Coronado. Possibly the culmination is found at Long Beach, where the pier is a double-decked affair, with a ballroom, concert hall, and a town, so far as shops are concerned, all out at sea.

At Venice the pier is equally remarkable, having a 
vast hall, music room, or dancing pavilion far out over the water, not to speak of a hotel in the form of an ancient galleon. Here is an imitation of Venice, Italy, and one may enjoy the delights of the gondola, as well as go a-fishing. At Ocean Park and other places these piers are seen, all patronised by anglers, who seem to possess all the qualifications of Walton, patience, sobriety, and a peaceful mind. The game is usually though not always small: the surf-fish of the coast, smelt, rock-bass, and occasionally halibut, yellowtail and white and black sea-bass. But the smallness of the game does not discourage your real fisherman; it is not all in the game, but the art of fishing, the anticipation.

The pier is high above the water, to clear the long rollers that at times come piling in ; hence the majority of the anglers use long stiff bamboo rods and big reels by which the fish can be lifted, and the renting of rods and the selling of bait is a remunerative business alongshore. One may see the sides of these long piers crowded day after day by anglers-men, women, and children; a remarkable demonstration of the universal fascination which angling has for mankind. There is nothing quite like it, except along the Thames, where at times hundreds of men may be seen patiently and philosophically holding a rod for game of the smallest size. Doubtless the anglers hope to land a five- or sixpounder, and without hope and patience there would be no anglers. But the secret is that these fine piers with 


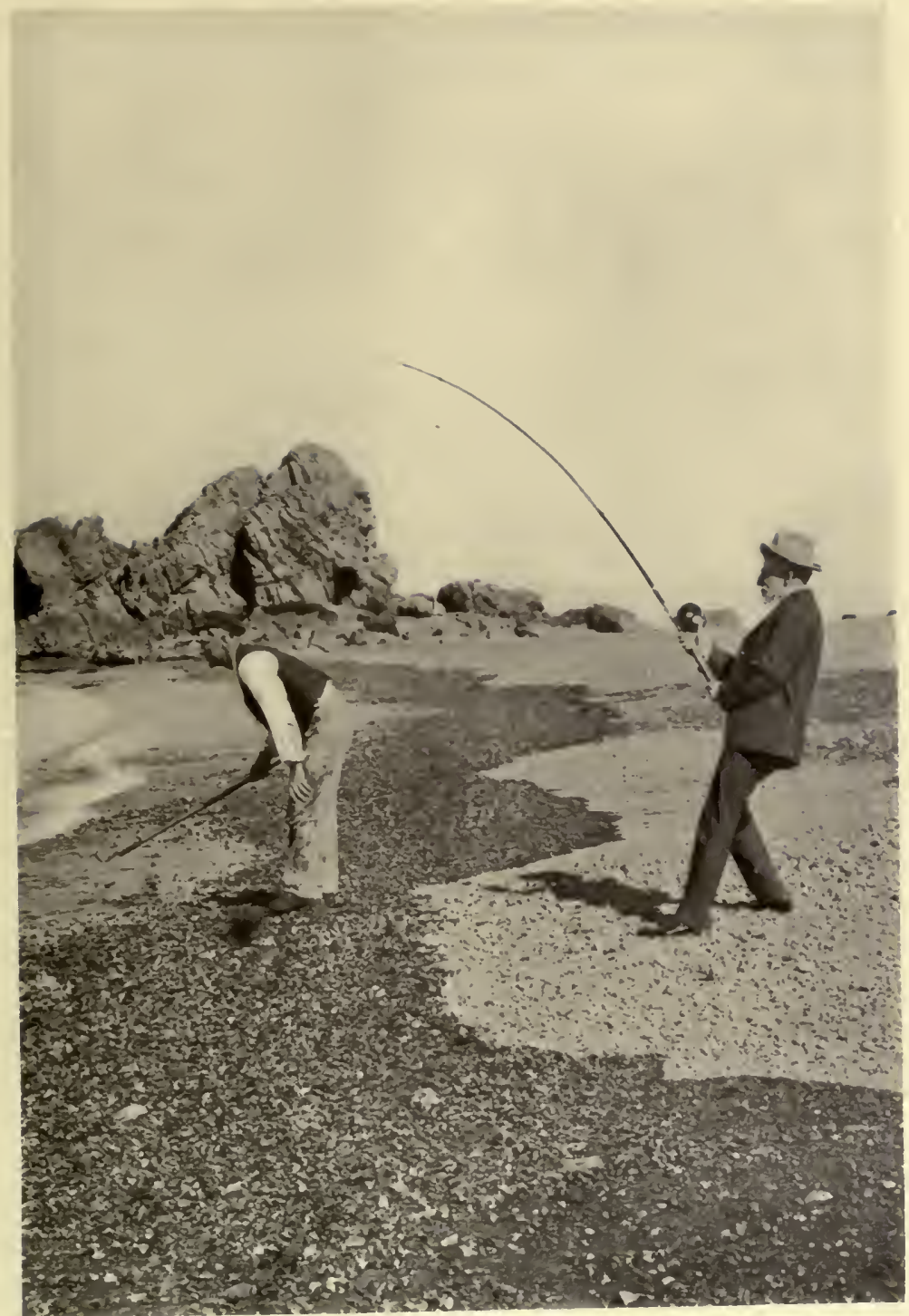

Beach Fishing for Leaping Sharks, Catalina Harbour. 



\section{The Still Angler}

their bands, dancing halls, lectures, organs, and ship hotels, afford the people a voyage at sea, its delights and pleasures, without any disadvantages. The green sea comes piling in in tidal measure, the surf high, a delightful spectacle as it breaks, affording the angler the perspective, the spume and dashing spray, all free as air, and the angling thrown in. I do not know who invented the angling pier, but he was a wise man in his day-a public benefactor.

While the majority of the game is small from the pier, there are fishing launches near at hand, and you may go outside and troll for barracuda, bonito, or yellowtail; or you may anchor in deep water and fish for the big black sea-bass. These boats and others take you to the great breakwater of San Pedro, a harbour which cost five million dollars, and to Point Firman and Portuguese Bend, the home of the mainland abalone fisheries. At the former point can be seen at low tide during or after a storm some of the most remarkable waves on this or any coast, well worthy a visit even if a winter gale is blowing. Off the point a rock rises out of the sea from a great stratified platform; as the sea comes piling in it strikes the rock, and is sent whirling, it is said, three hundred feet into the air, the dome of water assuming many beautiful shapes as it rises and falls, at its climax or maximum height resembling a splendid fountain, or some terrible explosion which has forced tons of water into the air in the shape of silvery pompons.

At night, when the darkness is intense, this 
marvellous flocculent mass becomes a pillar or fountain of fire, due to the remarkable phosphorescence of the water, which at times has assumed so fiery a hue that thousands were attracted from the interior towns and cities.

The still angler occasionally varies his sport by going out upon the beach, and with a long rod and heavy sinker casting for surf-fish or other game. You may see the long stretch of sands dotted with these monuments of patience, these advocates of philosophical reflection and the peaceful arts, who face the rich strong wind and salty spume, and are happy if they do not get a gudgeon.

Along the laguna shores I have found good beach fishing for large rock-bass, standing in the water and with a fairly stiff rod casting fifty or sixty feet from the sands. I have caught sheepshead from the rocks, yellow-tails from Avalon Beach, in the old days, and have seen the little beach lined with anglers, all of whom ultimately became involved in unutterable confusion as the big and gamy fish crossed the lines and amused themselves at the expense of the anglers. At certain beaches at Santa Catalina there is fair leaping-shark fishing, particularly in July and August, at Catalina Harbour. The heavy bait is carried out by the gaffer, who stands by on the beach and gaffs the game as it is reeled in. This is the luxury of angling. You do not leave the dry sand-that is not necessary, your gaffer does that-as there is no surf, the harbour being as smooth as a lake. A strike comes, and as you hook 


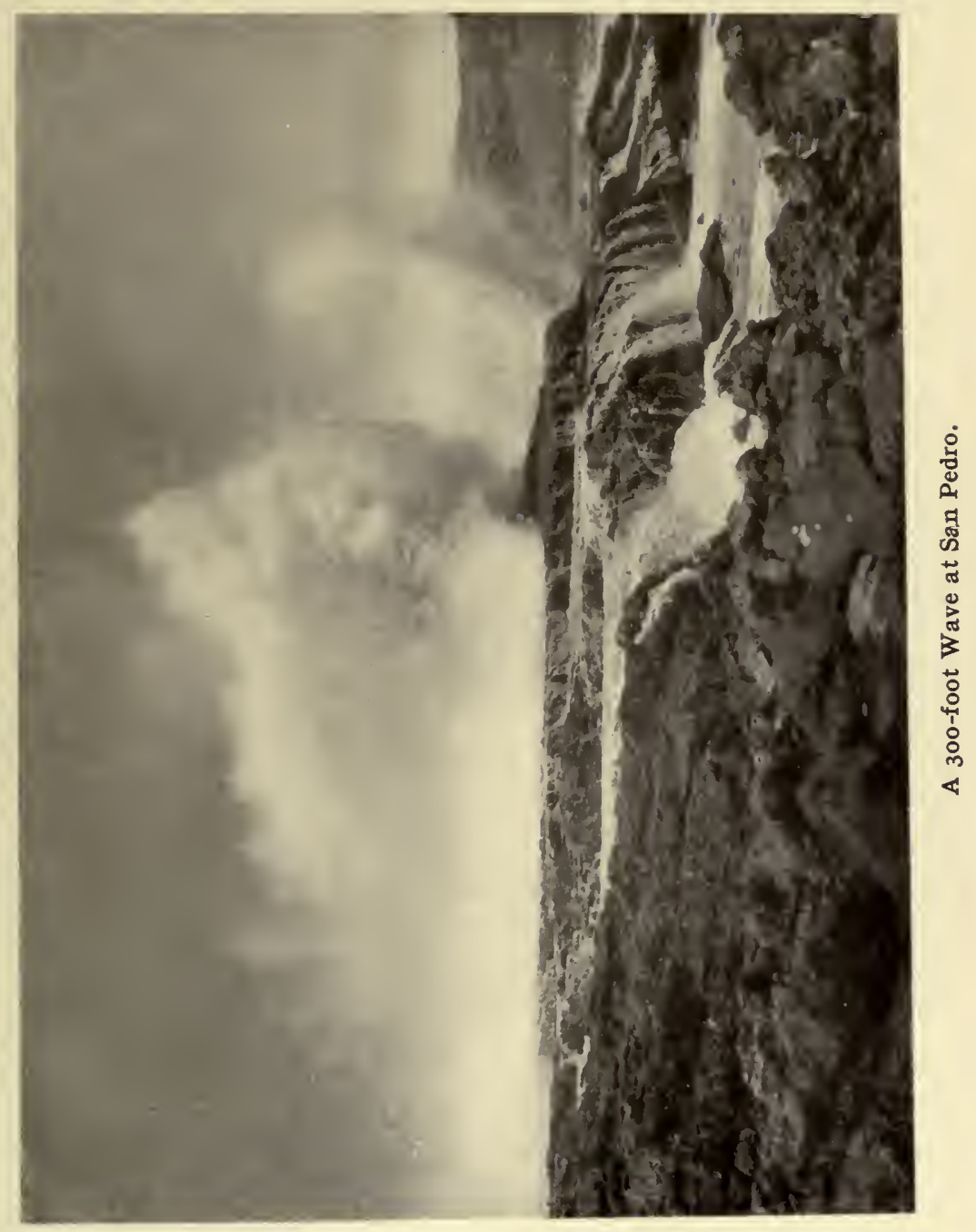





\section{'The Still Angler}

the game it leaps two or three feet into the air and often repeats it; a sixty-pound shark (my own record), striped gray and black, like a tiger. He carries you up and down the sands, and affords excellent sport for those who like the more robust piscatorial indulgences.

You may see the still angler, on the inner bay, sitting on the sands at Alamitos, while over on the sanddunes is his family listening to the music of the sea; or he is stationed at intervals on the outer beach down in the direction of Newport, his rods thrust in the sands and tagged with flags. Again you find him at the great railroad pier at Port Los Angeles, or at Redondo, where the deep sea cuts in, at times bringing large fishes. 



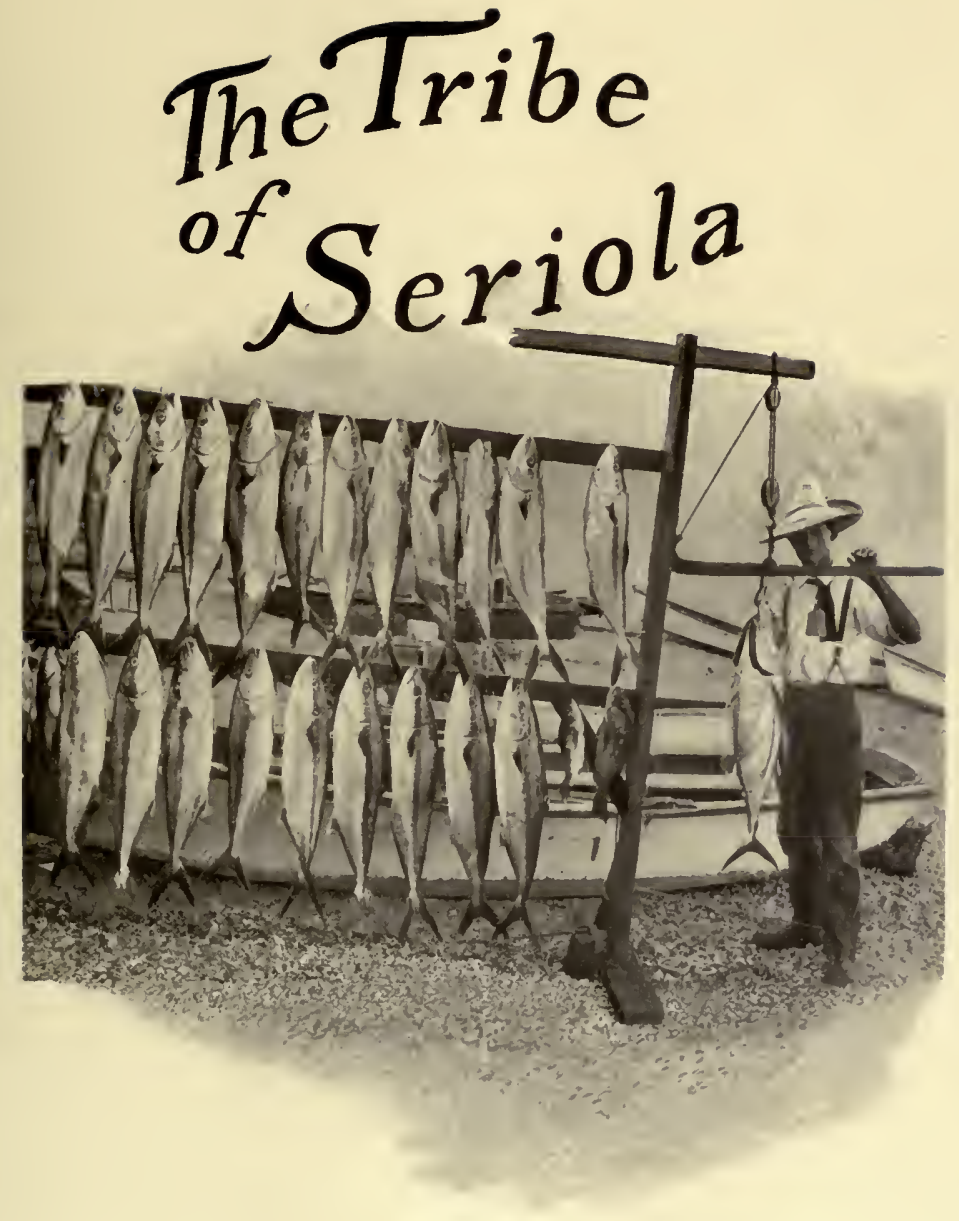





\section{Chapter XXV}

\section{The Tribe of Seriola}

$7 \mathrm{HE}$ angler who has fished in Florida from Palm

Beach to the Gulf has an especial pride in

1 his amber-jacks-one of the gamiest fishes of the Gulf Stream, running up to eighty or more pounds. clad in splendid vestments of colour, silver, gold, or amber; a type of matchless cunning and strength. On coming to the Pacific slope, or to Southern California, he finds a cousin of this fish; not so thick-set, longer and a little more slender, but a near kinsman of the royal family, a Seriola, known here as the amber-fish, and by many other titles best known, perhaps, as yellowtail. It ranges from ten or fifteen pounds up to thirty or forty, and doubtless reaches one hundred pounds in its old age and best condition.

The amber-fish—call him what you will—comes from some mysterious realm offshore in March or April, increasing in numbers, as time goes on, until June, when he often throngs the Santa Catalina Channel and abounds in such numbers that the great schools fairly 
tint the water with gold. They soon break up into twos and threes, or small schools, and can be caught, trolling or still fishing as the case may be; and the ease with which they are hooked gives the splendid creature the place of the bluefish of the Atlantic.

You may see the angler at Avalon sitting on post or string-piece of the dock angling for yellowtails and rock-bass-men, women, and children,- while out in the bay is a large fleet of rowboats, angling for this gamy roustabout that has been known to jerk a boy from the pier.

They tell a story at Avalon to the tenderfoot, which I will not vouch for, to the effect that one morning service was being held in a tent chapel, this being before the days of churches, when a small boy came in, whispered something in the ear of a man, who immediately got up and went out. Presently another followed, others joined him, and when two thirds of the congregation had left, the Presiding Elder, unable to resist any longer, so the story goes, cried out, "Hold on, brethren, let 's start fair," and hastened down the aisle, and was soon seen on the beach where every man, woman, and child had gathered to see the greatest run of yellowtails ever witnessed at the island. They filled the waters of the little bay, a ravenous throng which bit at anything, and the beach was soon lined with anglers, who were involved in confusion worse confounded. No one who has not seen a similar sight or a jack-beat in Florida can form any conception of it, or the com- 


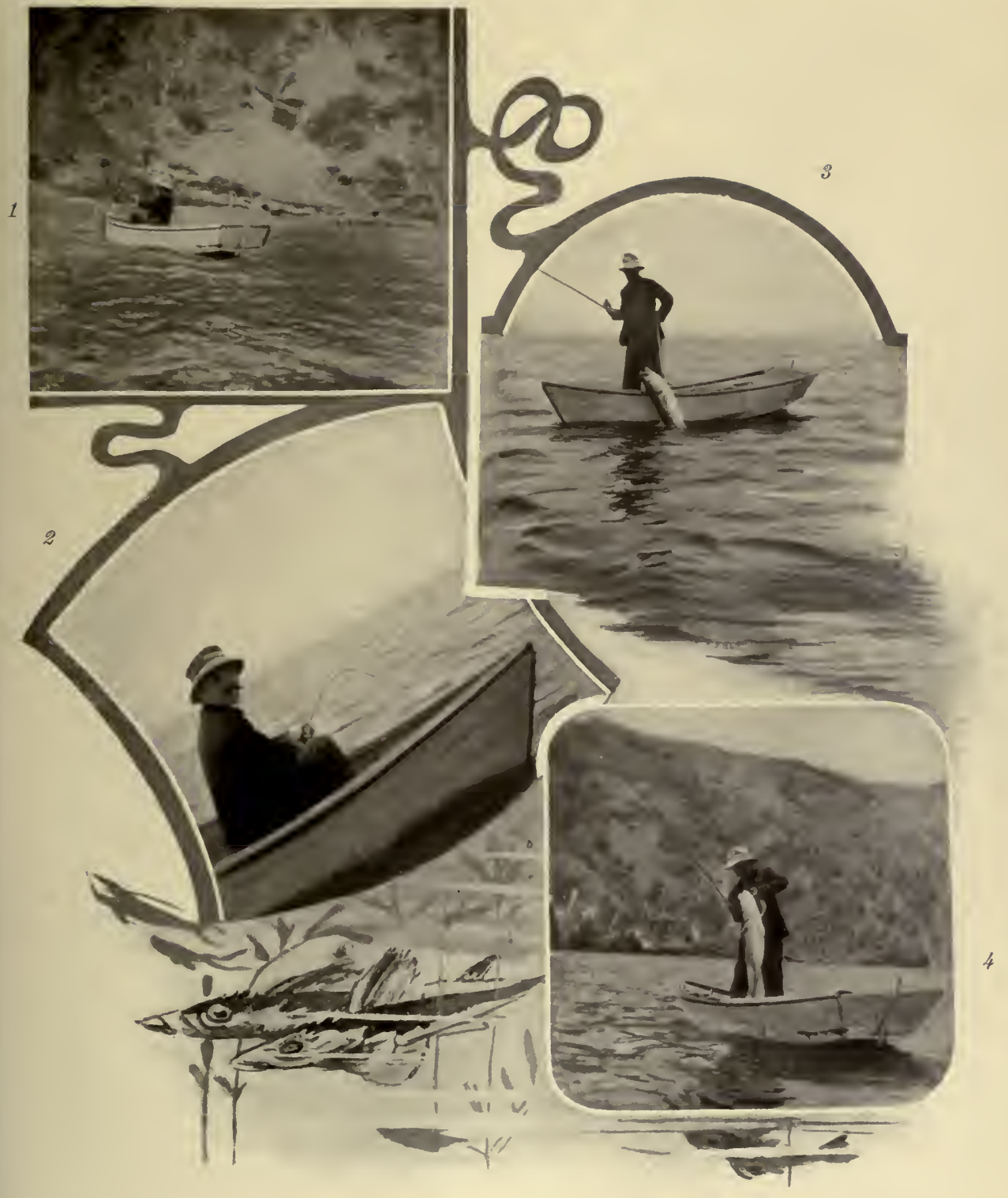

Taking the Yellowtail.

(I) The strike.

(2) How the rod appeared after thirty minutes.

(3) Gaffing.

(4) "A thirty-five pounder." 



\section{The Tribe of Seriola}

plete demoralisation that fills the soul of the still angler, who, from a simple philosopher of the stringpiece, becomes a wild man; and to see these anglers standing on the sands, the line of one entangled with that of another while the fish are biting, is to witness unutterable anguish-no contingency so tries the soul of man-the temptation of Saint Anthony was a bagatelle to that which dangles red before these martyrs; who invariably fall from grace, and swear by Jove and all the gods and prophets.

It is the fish of the people, and one of the sights in summer alongshore is to see the yellowtail fleet in August drifting or anchored at Avalon Bay. There are from fifty to one hundred boats, ranging from rowboats to launches, with men, women, and children angling for a fish that averages twenty-five pounds. No such rod-fishing can be seen anywhere in the world, so far as known, and-this is said advisedly,-this one fish alone would make the angling reputation of Southern California. The big island is a wind-break, giving water often as smooth as glass and of an ineffable blue. Glancing down into it you see a wealth of streamers, long beains of light pulsating, throbbing, extending here and there and bringing out into strong relief a variety of marvellous shapes, crystals, the very ghosts of animal life, yet living, pulsating animals. The most ardent angler cannot fail to notice these fairy forms, as some are fishing in boats with glass bottoms through which the smallest creatures are seen with 
perfect distinctness; and those who know, see that the ebb and flow of animal life is similar to that of Naples and the Mediterranean.

As the anglers sit and watch the drift in this floating throng some one raises a shout, and from the throats of the people in the yellowtail city comes a roar; shattering all the ethics of angling, as the man who has hooked a fish is encouraged in loud and joyous tones by every one else; there is no trace of envy here, and voices shout, "Good boy!" "Give it to him!" "Go in and win!" and other consoling phrases well known to anglers.

The victim takes it pleasantly as he is in the floating village by choice, and there are sixty miles of shore where he can fish alone; so he plays his game and is not " rattled" by the roars of advice.

Glance at this game and its play. The lucky angler has a light rod weighing not over ten ounces, a line known to the trade as a number nine. $\mathrm{He}$ is in one hundred feet of water and has hooked a yellowtail weighing at least seventeen pounds. Will he land it? That is the question. If cheering and vociferous encouragement be an aid, he will. The fish has taken one hundred feet at the start; the rod is bent into a suggestive curve, and the reel is making music that is heard high above the noise. He has tossed off his painter, and the fish is towing the light skiff out into the channel, making for deeper water. Every now and then the reel sounds as the yellowtail makes a 


\section{The Tribe of Seriola}

rush, and you see that its peculiarity of playing is to make a series of mad rushes that are irresistible. Zee, zee, zeee! sounds the reel, again and again; the crowd, catching the melody, takes it up, and the roar of sounds drifts over the waters into the cañon, and gives the angler who cannot go a-fishing a sharp and poignant pang.

The fish is down and out three hundred feet, hence, must be lifted; and we see the angler lower his rod, reeling quickly, "pumping," in this way gaining on the fish, that occasionally breaks away to the accompanying music of the reel, then comes slowly in, all the time bearing off with a force and vivacity that tests every fibre of rod or line, and angler's muscle. If you were near enough, you would see deep in the heart of the azure channel a blaze of silver, with flashes of gold. The yellowtail is a hundred feet down at the end of thirty minutes, and the skiff one hundred yards from the fleet, where, perhaps, other anglers are in the toils. The fish is upon its side, bearing off gallantly, making the fight of its life.

As it comes in, it rushes around in a big circle, then plunges down, zee, zee, zee, zee! until the tired angler loses nearly all the line he has gained, and it is such a thread, this nine-strand affair, that great care must be taken, as the slightest mistake, the merest over-pressure of the thumb and it is gone, and the yellowtail sails away. But your angler is a cautious fellow; he has fished before; he watches every move, and suddenly you see 
him reach for his gaff-and, presto! he lifts a great silvery creature up out of the blue sea, holds it a moment and laughingly nods at the floating-village people, who send across the water a volley of congratulations.

And the fish? A noble fellow-silver belly newly polished in the ocean mint, clear as silver can be, tail and fins gold of California, and along the side a stripe of the same. Its back is green in the water, but now is a blue deeper than that of the sea; the blue you see in some minerals, in the heart of an opal and in the blue heart of labradorite. It is nearly four feet long, and weighs thirty-two pounds, yet nothing is thought of it. The angler slips back into his place and shouts congratulations to some other fisherman, as in the three quarters of an hour of play perhaps a dozen such fishes have been caught or brought to the gaff.

The fishing-ground is a delight in itself. The air is cool, never sultry, and if one wishes wind, why, it is around the turn at Seal Rocks where the fresh inshore breeze, called by the desert, is driving in the scud and spume high on rock and sand.

So much for still fishing for the yellowtail; and if he is not in a responsive mood the boats move slowly along the rocky coast about fifty feet from shore in water as smooth as any inland lake (though you are twenty miles out in the Pacific), and you troll with about sixty feet of line out, and perhaps a heavier rod, say sixteen ounces. The bait is a four-inch sardine, or a spoon, and sooner or later it is taken and the experi- 


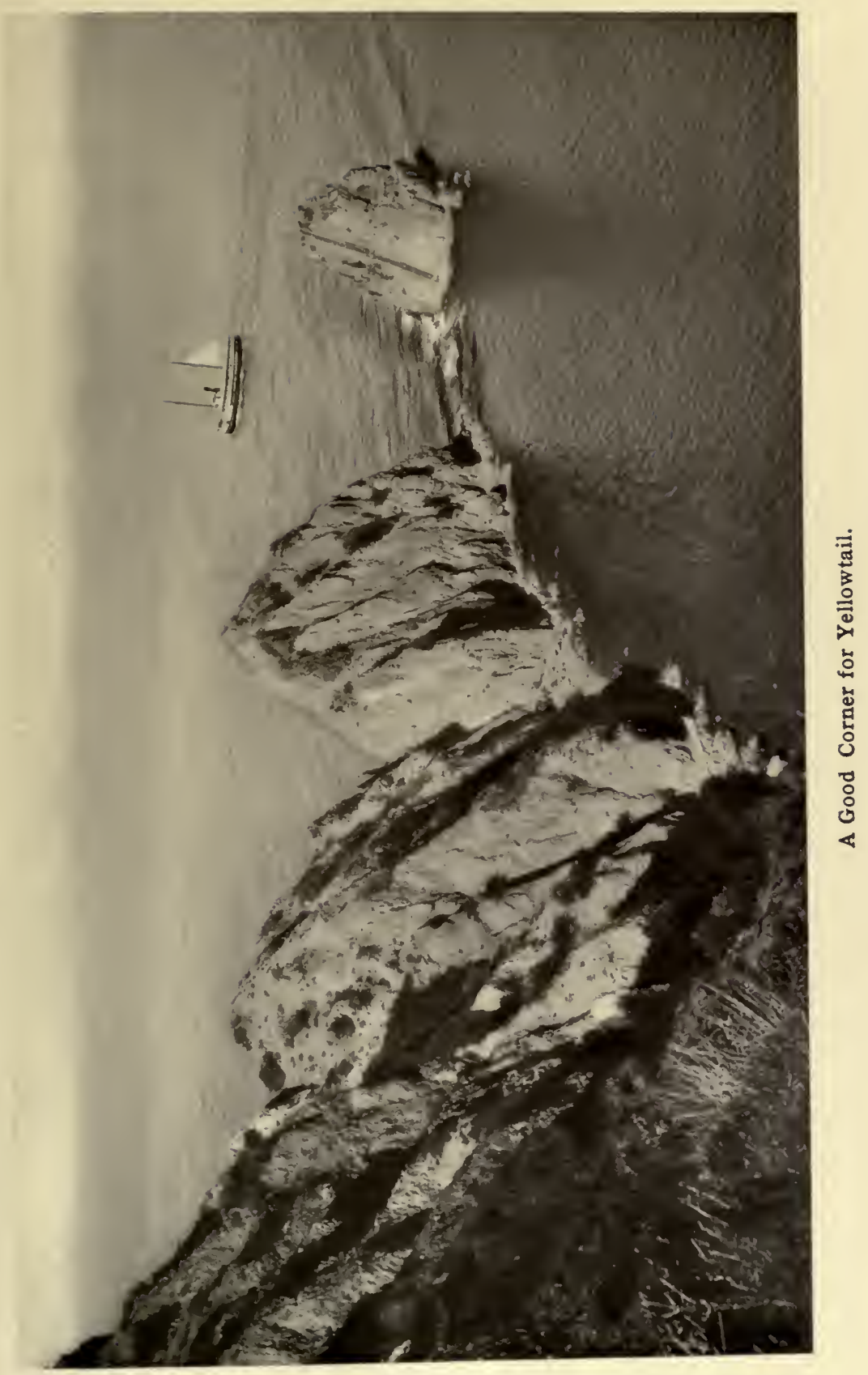





\section{The Tribe of Seriola}

ence is repeated. There is hardly any play that quite comes up to that made by this fish. Its fierceness, its sudden rushes, its evident strength, all are factors that surprise old salmon fishermen and dumbfound the tenderfoot in these summer seas. Santa Catalina is the home of the yellowtail, so far as the rod angler is concerned, as here the equipment of boats is perfect, the water smooth, and the fish found in large numbers ; the rocky cliffs, the long ideal stormless summer days appealing to anglers, some of whom have a weakness for creature comforts even when fishing.

The yellowtail is found as far north as Monterey, and where deep water sets inshore, as at Redondo and Portuguese Bend; it is caught, also in mid-channel. Schools may be found all along the coast where they are taken by the professional fisherman with his handlines and bone-gigs. But the ideal rod-fishing is found in the lee of the channel islands, from San Diego and Coronado to Santa Barbara, where still waters and ideal conditions make the sport unique in the annals of rod-fishing for big game.

Yellowtail fishing at the islands continues all summer and up to December, and I have taken this fish at Avalon from the pier nearly every month in the year; but officially Seriola is on leave, December, January, and February, and is then only caught on hand-lines six hundred feet down in the San Clemente Channel, or off the great banks of Tanner and Cortez some miles to the south-west, or down the coast at Ensenada. 



\section{The \\ Glimate}

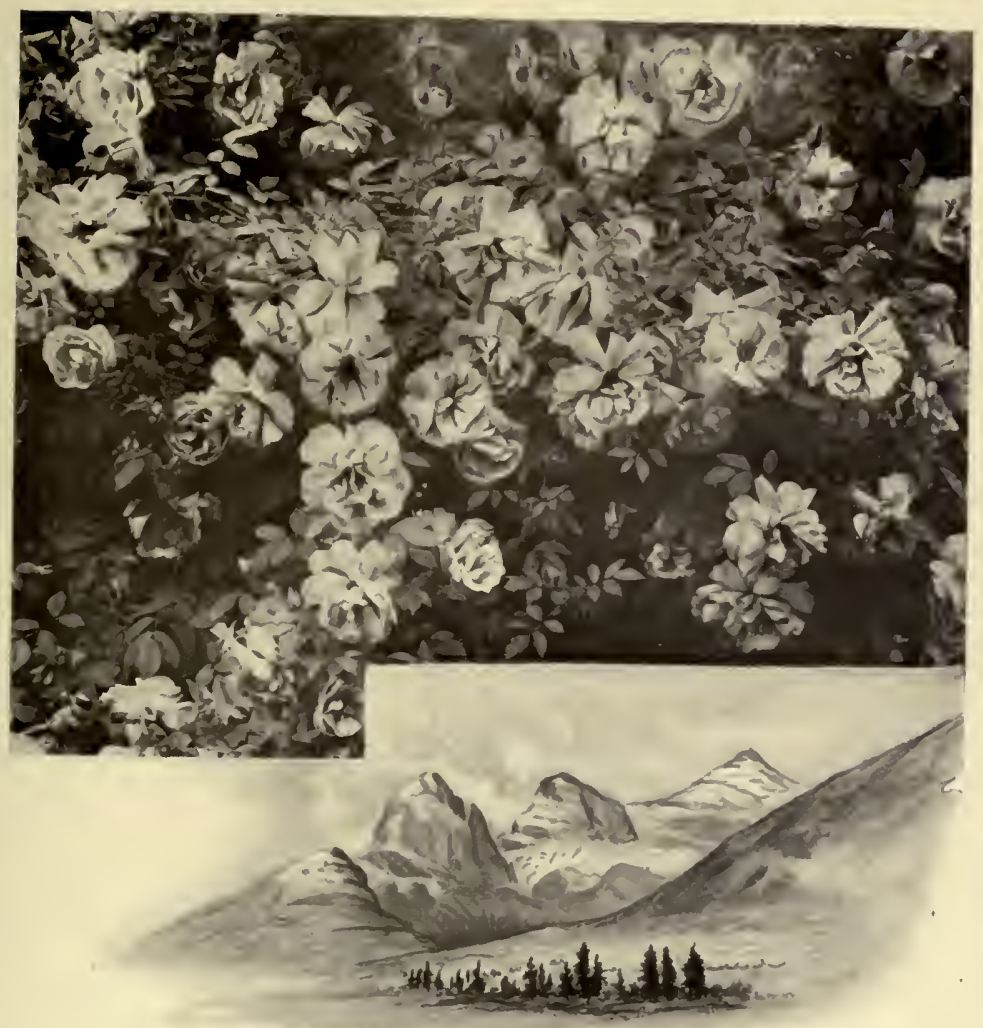





\section{Chapter XXVIII}

\section{The Climate of Southern California}

NFORMATION regarding the climate of a locality is essential to the sportsman or traveller.

1 Aside from its fame as a sportsman's paradise Southern California has become noted as a health resort; yet its peculiar climatic conditions are but little understood, as instance the party of otherwise intelligent people who, proposing to spend the winter in Southern California, packed away their winter clothing in New York and came to Los Angeles in a private car, garbed in muslins and duck and with wardrobes light enough for Samoa.

I was first impressed strongly in favor of Southern California by the remarks of a Southern Californian of wealth, who had no real estate to dispose of. He told me that, obliged to seek a mild climate for a permanent residence, he began a tour of the world, making an extended, and, as he considered, an exhaustive series of researches, living in all the famous health resorts known, as the Azores, Madeira, the south of Italy, France, Spain, and Cairo, Florida, Colorado, and other States. 
In the course of time he reached Southern California, and after several years' trial selected the San Gabriel Valley as having the most perfect climate he could find in a civilised country for continuous residence. My own home for twenty years has been but five miles distant from the ranch of this well-known and enterprising citizen, and, while I have not made extensive investigations abroad, I have in America, and am confident that his judgment is unbiased and his assumptions correct and logical.

The perfect climate, in all probability, does not exist, but I believe that parts of Southern California come nearer to it than any locality in the civilised world. A locality cannot be adequately judged by a single year, as some seasons are wet, and some are dry; the real test is by the decade, or better by two. Orange trees thirty years old bloom in my garden, giving the answer to the query as to the lack of extreme cold in that time.

The variety of climates in Southern California, their remarkable range, are the features which impress the new-comer, and are well illustrated in the following incident: Some years ago, I published anonymously in a New York journal, the Evening Post, if I am not mistaken, a statement to the effect that the residents of Pasadena could pick oranges, bathe in the ocean with a temperature not much cooler than that of Newport in summer, and enjoy sleighing and snow-shoeing, all in one day. This extraordinary statement-from the Eastern standpoint-was regarded a joke by the press, and quoted as 


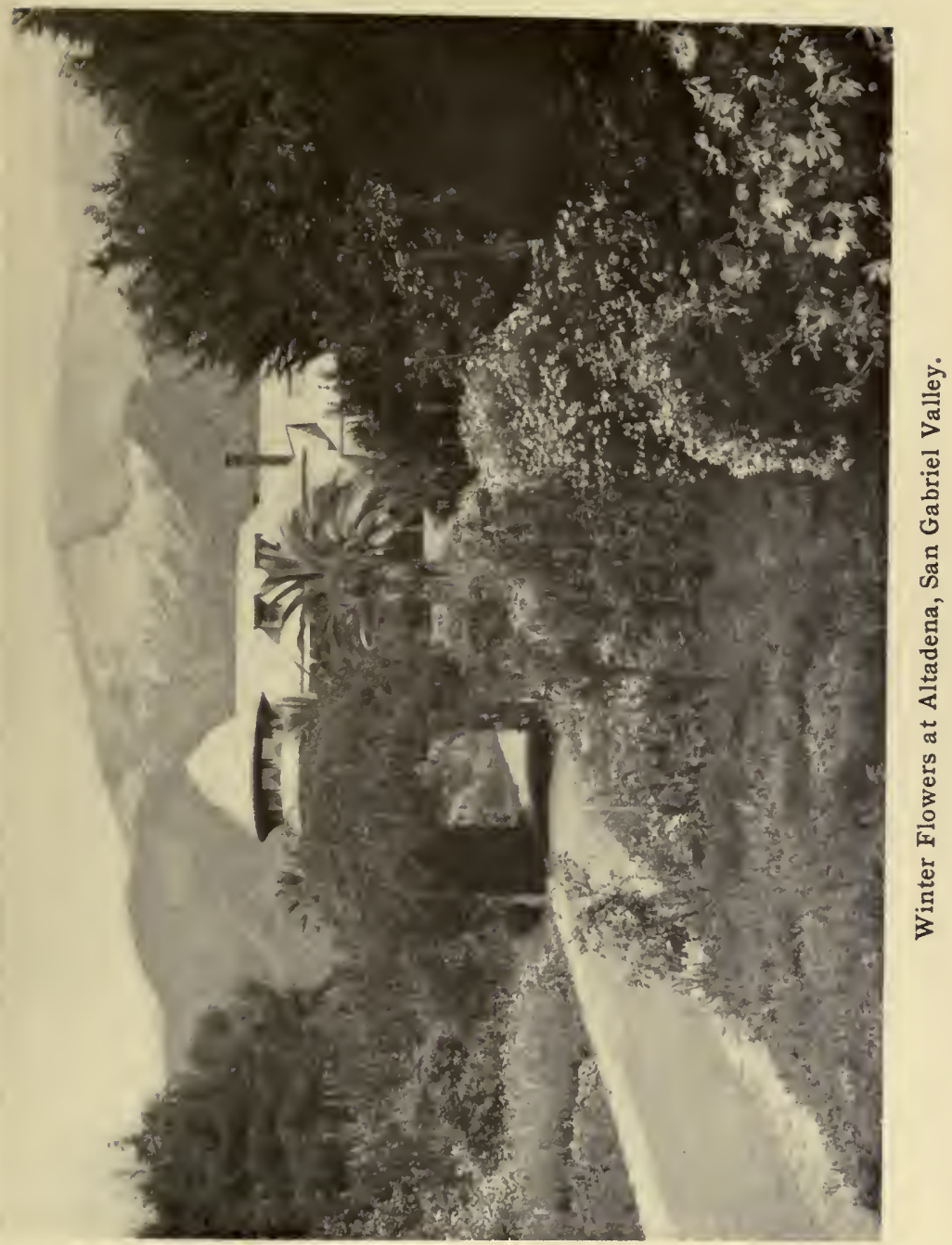





\section{Climate of Souhtern California 363}

a fair sample of the "California big story," and considered a figment of the imagination pure and simple.

The Pasadena Board of Trade several years later took the matter up and decided to show the world that it was not only a very simple thing to accomplish, but the tourist, sportsman or invalid could find in one day any altitude and climate from sea.level to six thousand or even ten thousand feet; semitropic summer, and all the grades of climate and climatic variants up to snowbanks, and winter, drear and desolate.

The extreme altitude mentioned was on San Antonio and San Jacinto Mountains, snow-covered in winter, and reached from Los Angeles or Pasadena in a few hours; but the Board of Trade devoted itself to Pasadena. They appointed a committee of well-known citizens, and, with a photographer to illustrate their experiences, started one day in February, or mid-winter, to prove the story. The town or city of Pasadena lies at the base of the Sierra Madre, which here rises abruptly to an altitude of six thousand feet, and at this time the peaks were white with snow down to the four thousandfoot level.

Extending up this mountain range in Rubio Cañon was a cable road, the Mount Lowe Railroad, that in a few moments carried the passengers from the base to the thirty-five-hundred-foot point, and while the committee was not dependent upon this mode of transportation, there being horse trails, they proposed to utilise it, and laid out an itinerary which covered every 
point in the discussion. The accompanying illustrations tell the story. The committee at IO A. M. met in the orange grove of the late Andrew McNally of Chicago, where they ate oranges, then picked roses, and idled in a wealth of flowers that made up the garden. At I I we find them on the mountain railroad at the foot of the incline. At I $2 \mathrm{M}$. they had entered the snow level, thirty-five hundred feet up, soon reaching Alpine Tavern amid a scene that epitomised winter.

Hundreds of square miles of mountains stretched away white with snow, and on distant peaks the wind was blowing snow banners into the air. Here a sleigh met the party, and they were carried still higher up the mountain, amid huge snow-banks where with snow-shoes they walked about and enjoyed the novelty of snowballing. At I.3O P. M. they were again at the NcNally trout pool, in the land of summer, and at 3.30 P.M. we might have seen them, as did the photographer, bathing in the waters of the Pacific at Santa Monica, from which they steamed back to the orange groves of Pasadena, where late in the afternoon they assembled in the orange grove of one of the party and read the congratulatory telegrams of their feat. In a few hours they had passed through various climates, from semitropic summer and ripening oranges, to the heart of winter, and altitudes from the sea level to over a mile above it, all attainable in half a day if desired, and in the most comfortable, indeed luxurious, fashion.

Few localities have so many singular conditions 


\section{Climate of Southern California}

liable to affect the climate as Southern California. It is an oasis of limited extent encompassed by deserts which have few equals for heat on the habitable globe. There are mountains of great height, abysmal sinks two hundred and eighty-two feet below the level of the sea; indeed the country is a maze of mountains, the people living in the valleys or along the seashore enjoying what is, in all probability, the most perfect climate known.

The impression has gone abroad that Southern California is a winter resort, with a burning summer, when in point of fact the shores of the Pacific from Santa Barbara to San Diego, and often miles inland, are remarkably cool in summer; the heat conditions which hold on the North Atlantic coast being unknown. There are warm, often intensely hot, days in the interior towns and valleys in August and September, but the nights are almost always cool, and one of the objections some people have to Southern California is that one cannot dress in light clothing and sit out of doors every evening, as they are, as a rule, too cool. As an illustration of San Gabriel Valley climate, I am writing these lines on August twenty-first in Pasadena, twenty-eight miles from the ocean, at noon. My room faces the north, or the garden, and the windows and doors are open. It is a warm day in Pasadena, but my room thermometer shows $70^{\circ}$, and this has been the average for me all summer with few exceptions; later it becomes warmer for a few days, then cools off again; all of which leads me up to 
the statement that personally, after a trial of twenty years, I prefer the summers of Southern California to the winters, and after residing in almost every section of the country I believe Southern California possesses a more than remarkable climate, winter and summer, if judged by my stadnard,- - the experience of two decades.

I have seen winters when it rained too much, I have seen five or six years when it did not rain enough. I have seen long hot summers when the inland towns were extremely uncomfortable, but judging the country by the rule of general average, by five years, a decade, or two decades, it stands in my estimation without peer, as the nearest to the fabled perfect all around climate.

Southern California has all the advantages of the Riviera without any of its drawbacks, as the hot winds from Africa, its cold winds from the Italian Alps, and to-day it is the centre of high civilisation, radiating from Los Angeles, a city with a winter population of two hundred and fifty thousand souls, from which the pilgrim can in a few hours, as I have shown, reach almost any altitude from the snow line to the level of the sea.

It is difficult to describe the peculiar climate of Southern California, which is now, and always will be, the loadstone to attract thousands to its shores. The entire country has been built up from a series of Spanish-Mexican ranches to an American principality in thirty years and is made up of the cream of the people of the East and Europe, who have come to California not all as pioneers or invalids, but in the main men and women 


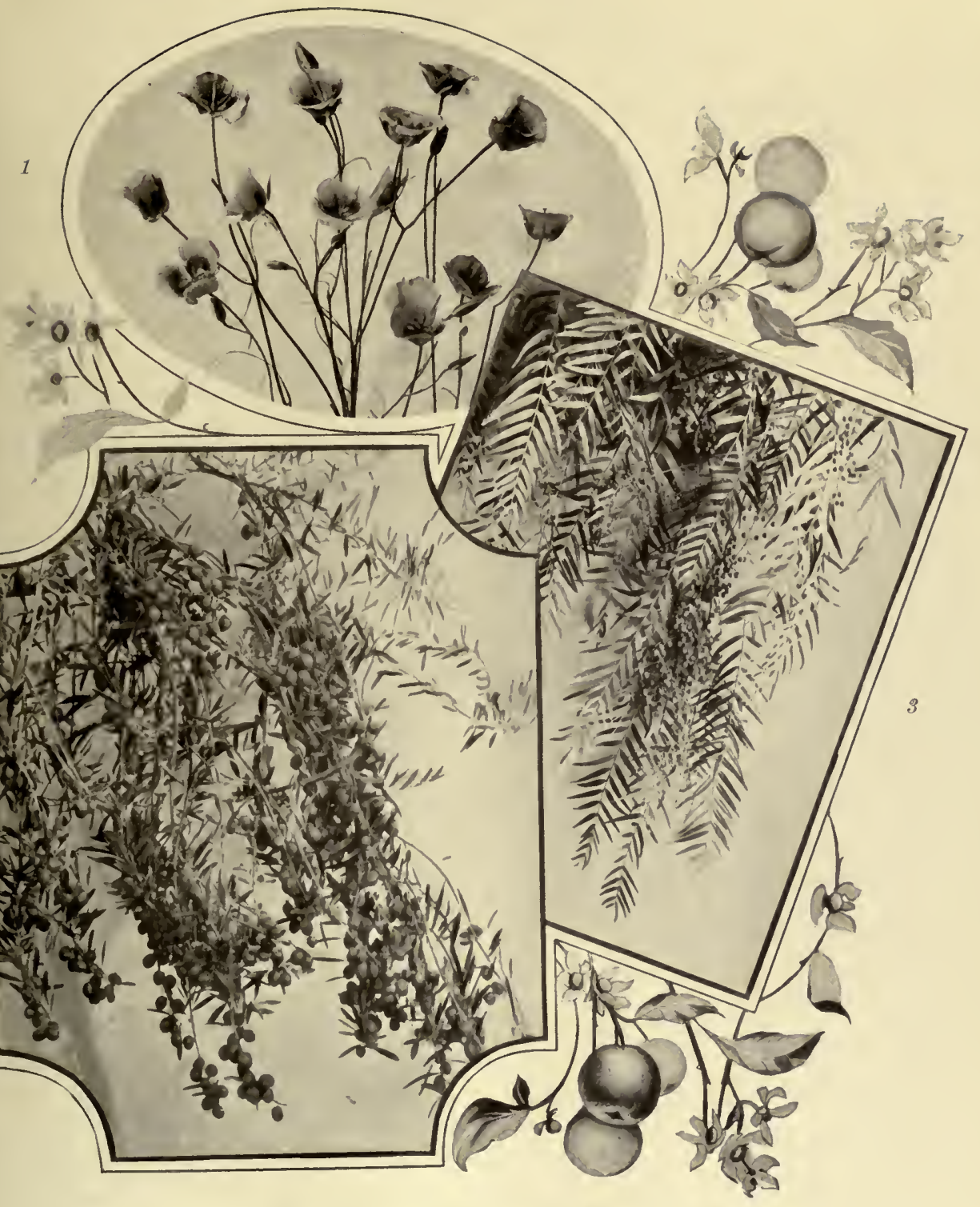

Winter Verdure in Southern California.

(1) Mariposa Poppy. (2) Olive. (3) Red Pepper Berries. 



\section{Climate of Southern California}

of wealth in search of that chimera, the perfect climate; the climate without marked seasonal changes and extremes. The pictures of Southern California display a wealth of palms and other tropical verdure; hence in the public mind the country is considered tropical, and the tourist is often heard to remark, "If your winters are so mild your summers must be very hot," and the same tourist waxes indignant when the Californian states that Los Angeles is fifty per cent. cooler than New York in summer.

Southern California produces a semi-tropic vegetation as well as productions of the temperate zone, but it is far from being tropical. This is not better illustrated than by saying that in winter Southern Californians dress as do Eastern people. They wear winter clothing, and for two months or longer have furnace- and grate-fires, and are extremely uncomfortable if they do not. They wear overcoats at night and when riding, yet at mid-day they often let the fires go out and throw open the doors and windows; indeed it is the cool nights that make the winter.

It seems very cold on these winter days to the newcomer, but just how cold it really is I leave the reader to realise when I say that in front of my house the heliotrope climbs to above the windows of the first story. This is protected by the eaves, and is on the south side of the house, yet in eight years it has never been touched by frost, though I have found ice in an Indian mortar near by in the early morning. It feels cold and pene- 
trating, but if the dweller in the land goes out of doors and takes normal exercise it is not noticed; at least the heliotropes, roses, stocks, violets, and countless others are growing in the open air every day in the Southern California winter.

I should call the climate of Southern California temperate, with a very small rainfall; a region with two summers : one cool, from December to April, another warmer, from April to December. During the cool summer it rains on the average fifteen inches, about half the rainfall of Boston or New York. The rain often falls at night. The remainder of the year it does not rain, but the towns and cities are supplied with water, in pipes, from the mountains. They turn this on lawns, and irrigate their ranches from the same source.

A climatic glimpse of the year may be given. In November the skies are clear, or perhaps in October, and the weather is cool. Suddenly, long, slender masses of cloud appear along the mountain-side, coming from the south-east, and persist during the day. They disappear, come again, and, after many trials, one night it begins to rain for the first time since May, or earlier. This initial rain may continue several days, mostly at night, or it may clear after a few hours. If there has been a fall of two inches, or even one, an almost immediate change is noticed. The air is free of dust, the trees are washed down, and all nature puts on a smiling face, and where the atmosphere has been hazy and 


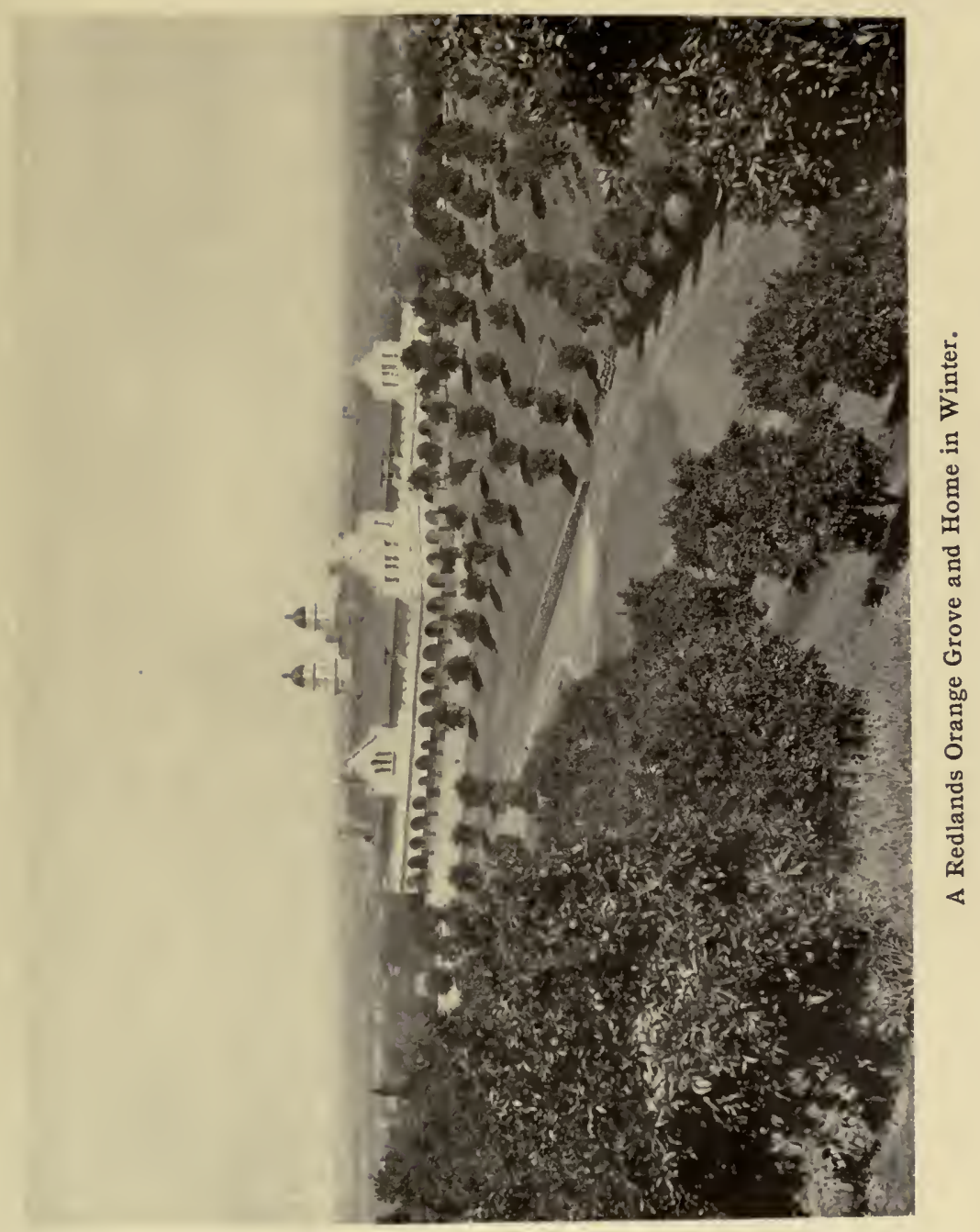





\section{Climate of Souhtren California}

thick it is now clear. The mountains appear so near that you feel that you can almost touch them. In a short time a wonderful transformation comes over the face of nature. Along the roadway lines and masses of green appear, and so rapidly do these increase and broaden that in a marvellously short space of time the land, that a week or so before was gray with dead grasses, is now a vivid green. Nearly all this is alfileria and clover. Soon the grain-fields that have been planted sprout, and another hue, that of barley, oats, and other grains, is seen rippling smiling in the sun, and from the tops of hills a covering of delicate green reaching away to the distant sea.

The so-called rainy season is now on, and if a normal one it should rain a day or two once in three or four weeks. But sometimes the storm continues for a longer time, and there is a "wet winter," and it rains as much as it does in the East, or forty inches; but the average for Los Angeles may be said to be between fifteen and twenty inches per annum, or half that of the New York year, and the country appears to thrive better on it. If rain fell in the summer the dry, cool climate would disappear.

In December or January, if the rain comes early, the country is soon a vast flower-garden, a field of the cloth of gold, ablaze on the upland slopes with the Escholtzia or so-called California poppy, while elsewhere gleam the painter's brush, the scarlet mimulus, the bluette, 
countless daisies, cream-cups of delicate design, yellow violets, Mariposa lilies, the shooting-star, suggestive of the floral procession that marches on with the coming of winter days. The chapparal is now abloom, and in mid-winter the flaming red of Heteromeles is seen everywhere, and near the mountains the delicate lavender of the wild lilac. It is winter, but in some incomprehensible way the flowers are in bloom, only the sycamores and a few other trees being bare. The nights are cool, a fire is acceptable morning and evening, and the rains leave a mantle of snow on the high peaks; San Antonio, San Jacinto, San Bernardino are white all winter.

I can sit in my garden, amid roses and orange blossoms, and watch the snow blowing up the north slope of the former, forty miles away, and often the entire range is white with snow down to the twenty-fivehundred-foot line; but it will be gone on the lower range perhaps by noon, when the houses in the valley have thrown open doors and windows. The snow on the high mountains gives a delightful tang to the air, and makes the nights cool ; but the roses bloom on and on for ever, and the tomato ripens in protected valleys. I hardly know to what to compare such a winter; possibly October in the East, when occasional frost comes, but there is no autumnal display in the lowlands, no masses of colour except in the cañons; instead of dropping, leaves come out at Christmas. The yule-tide wreaths are of Heteromeles berries which 


\section{Climate of Southern California}

grow on the cañon side ; oranges and lemons are ripening, and the city gardens glow with every flower seen in the East in July.

So pass the winter days. The land is gay with tourists, and the now green golf-links of Santa Barbara, Coronado, Avalon, Los Angeles, Riverside, and Pasadena are filled with players; the mountain cañons are picnic grounds, and there are trips to the coast, and seabathing; and the towns along-shore-Venice, Long Beach, Ocean Park, Terminal, Santa Monica, Avalon, Playa Del Ray, Coronado, Santa Barbara, and others are crowded with an array of visitors from all over the world, basking in the soft and balmy winds.

The rain-storms now due are often not storms at all, but gentle winds. Again it blows heavily, and the rain that has been heralded off the Washington coast strikes Southern California as a south-easter; a southeast wind is an indication of rain. You are impressed by one feature in the winter that is sure and definite: you rarely have a day that some part of it is not available for an outing of some kind, and you have never passed a winter where there were so few rainy days. It is life in the open, and an abundance of it; a life of sunshine. Sometimes there is a "norther" and the air is "stinging," yet the flowers do not complain, and the orangetrees have never been killed down.

On these winter days the thermometer will read at mid-day from $65^{\circ}$ to $75^{\circ}$. On rainy days or during a storm it will read from $55^{\circ}$ to $65^{\circ}$. The rains are sup- 
posed to continue until April, coming once in three or four weeks, in no sense constituting a "rainy season," which is a popular delusion. In February or March there are often several hot days ; then the spring weather, cool, delightful, with high fog, comes and continues with an uninterrupted procession of beautiful days. The first really hot weather in May perhaps dries up the herbage or alfileria and clover. The crops of barley and oats are piled high, and are being baled; the vineyards are masses of green and the mesas are again taking on the brown hue of summer, though the chaparral, that clothes the hills and mountains, is always green. In May and June the tender tints of Calochortus, the Mariposa lily, white and lavender, cast a filmy sheen in little parterres or along the southern slopes of the hills, poising like flocks of literal butterflies over the gaunt and spined leaves of cactus. Early the graceful Brodæa paints the chaparral in vivid tints of lavender, and in the cañons the wild tiger lily gives a flame-like hue to the rocky slopes.

Every season has its floral host, and from May to July a signal blazes on the mountain-sides, tall stalks shooting up here and there like magic, the splendid ethereal bloom of the yucca, the "candlestick of the Lord," an angelus of the eternal slopes, the clang of whose bells is incense.

A strong breeze now blows regularly from the ocean, erroneously called the "trade wind," stopping at night to blow from the mountains, bringing a suggestion of sa- 


\section{Climate of Southern California}

line odors from the sea into the great valleys by day, and the aroma of pine and fir by night. Up to August 2oth there may be no disagreeable warm or hot days, and when it is warm it seems warmer than it really is. At one point, seven hundred feet above the sea, fourteen miles from it, the thermometer reached $100^{\circ}$ but twentythree times in five years, and the showing at Los Angeles is even more remarkable.

When days of excessive heat come, the wind is from the desert and it is dry, not dangerous; and during it the death rate of a large city like Los Angeles, with over two hundred thousand inhabitants, will not veer from normal, while a hot "wave" in the East will strike down hundreds, children and adults. This refers to the interior towns twenty or thirty miles from the sea, as Pasadena. Those nearer the desert are much hotter, but in all these places the nights are cool, and on the hottest days the man who stands under a tree will soon move into the sun to "cool off." In a word, in the East and South the air becomes heated and the interior of a house is nearly as warm as out of doors, but in Southern California summers the normal air remains cool; it is constantly coming from the sea and does not become heated in the Eastern sense; hence those who understand the country open up their houses early in the morning on very warm days, allow the clear night air to percolate through them, and at nine o'clock close the house, shutting out the heat, keeping the temperature at $70^{\circ}$ or below $75^{\circ}$ until three or four 
o'clock, when the wind is cooler and the house is thrown open.

At the seashore, the towns from Santa Barbara to Coronado, days so hot as to be a menace to comfort are extremely rare. The summer fog that is almost always to be seen off the coast, a high fog, is the balance wheel giving cool days. It comes in at night and rarely remains after sunrise, passing off leaving the grass dripping with moisture, often depositing one one-hundredth of an inch of water; the air is crisp and delicious. This fog, common to all the coast, is always welcome and is in no sense a menace to health, this being the consensus of opinion among leading physicians. Dr. John M. Radebaugh, who has lived twenty-five years in Pasadena, considers this region preëminent in America as a health resort; indeed the fog is regarded as a benefit to the land and its people.

The old resident in California will, as a rule, tell the new-comer that he knows nothing about the climate, and that all signs, especially the "rain signs," fail; yet there are certain facts relating to the climate that are definitely known. Perhaps the most conspicuous feature in the country is the constant cool west wind that blows all day, in fact everywhere in California, but south of Point Conception it loses some of its force and is a pleasant wind that makes Southern California summer climate what it is. It begins in the morning from eight to nine o'clock, increases in force until three or so, and then begins to wane; always steady, blowing under clear 



\section{Climate of Southern California}

skies, bracing and health-giving. I have been drifting in the Santa Catalina Channel in a dead calm when I suddenly heard a roar far away to the west, and have seen a ridge of whitecaps coming on like a tidal wave, the approach of the morning wind. Hardly has the west wind died down in the afternoon when it begins to blow in an opposite direction, and all night the land alongshore has a breeze that sweeps down from the verdureclad mountains.

Each day, then, in summer, Southern California has two distinct and opposite winds: one from the ocean, and one at night from the mountains and vast arid region which surrounds the land to the east, a rare combination that cannot but have its effect as a vigorous and health-giving tonic. In twenty years I have seen but two gales which were alarming to some people in the San Gabriel Valley, and neither one equalled the heavy north-easters I have known on the Atlantic coast and the furious wind squalls of the intercontinental region. Hurricanes and cyclones are unknown in Southern California. Four or five years will pass without a thunder-storm, and the town of Pasadena has been struck by lightning but twice to my knowledge in twenty years. These phenomena are not a part of the normal conditions of things; they are the rare exceptions.

There is a feature of the Pacific coast that many writers and authors credit with having a decided influence upon the climate of the Pacific coast. This is the so-called Black Current of Japan, the Kuro Shizwo, 
which sweeps up the coast of China from the tropics, crosses the north Pacific and flows down the west coast of North America. If this current holds its temperature to any considerable degree it would hardly seem possible that it should not to some extent modify the climate of California that differs so notably from points in the same latitude on the Atlantic coast; but Professor Alexander G. McAdie, professor of meteorology of the U. S. Weather Bureau, stationed at San Francisco, who has made a study of the climatology of California, believes that the current has very little influence upon the coast, and he ascribes the prevailing west winds, which are factors in the summer climate, to an "easterly drift of the atmosphere in temperate latitudes." The following is taken from Professor McAdie's report of 1903 :

"The prevailing easterly drift of the atmosphere in temperate latitudes, causing the well-known winds from the west, is one of the prime factors in modifying the climate of the coast of California. This coast line, stretching for Io degrees of latitude, is subjected to a steady indraft of air from the west. In this movement, together with the fact that to the west is the great Pacific Ocean, lies the secret of the difference in temperatures between the Atlantic and the Pacific coasts at places of like latitude. For some years there has been an impression that the milder climate of the Pacific coast was due to a warming influence of the Kuro Shizwo, or Japan current. No reliable data exist to support such a belief, and it is quite unlikely that the Japan current 


\section{Climate of Southern California}

plays any important part in modifying the climate of the Pacific coast. The active factors are, as said above, the prevailing easterly drift of the atmosphere and the proximity of the mass of water, a great natural conservator of heat. . . . It is probable that if one of these conditions (the easterly drift of the air and the proximity of the ocean in modifying climate) could be reversed and the general movement of the air in these latitudes lie from east to west, marked differences in climatic conditions would result, and the Pacific coast might then have a rigorous climate."

The cause of rains-why some reach Southern California and others pass east in the latitude of Oregon or San Francisco, and why it does not rain in Southern California from May to November-is often a puzzle to the stranger. Very briefly, the facts are as follows: What is known to meteorologists as the North Pacific cyclone belt is an important factor in producing storms in Southern California, which are cyclonic disturbances that rise or are created far to the west on the great Japanese current. The North Pacific cyclone belt, influenced by the sun, moves north in summer and follows the sun south in winter; hence in summer it is well north, and the storms which come in from the Pacific pass east without coming below San Francisco; but as winter approaches and the sun retreats to the south the cyclone belt comes farther south, and passing storms impinge on Southern California ; singularly enough, coming from the south-east or east, cloud banks creeping along 
the Sierra Madre range from that direction being almost infallible evidence of a coming rain in the San Gabriel Valley and Southern California in general.

Professor McAdie traced one of these storms by means of the logs of passing vessels. It began off the east coast of the Philippines, latitude $15^{\circ}$, longitude $150^{\circ}$ west, Nov. 20th, moving due west to about latitude $20^{\circ}$, longitude $130^{\circ}$ west. On the 9 th of December the storm was off Japan in latitude $39^{\circ}$ (approximately), longitude $150^{\circ}$ west. It now turned south-east, and on the I I th of December made a complete turn or loop in four days; then passed east along the 3 oth parallel, where on the 23d of December it began another loop north of the Hawaiian Islands, and on January $3 \mathrm{~d}$ again moving east and north-east, reaching on the 8th $45^{\circ}$ north latitude $145^{\circ}$ east longitude. Here it divided; one part went to the north-east, reaching land about $50^{\circ}$ north latitude on the 12 th of January, while another branch went south, then north-east, entering Northern California at latitude $43^{\circ}$ on the 12 th of January, then sweeping down across the State, reaching the latitude of Los Angeles, but to the east, on the $13^{\text {th }}$ of January.

This storm took a month to pass from near the Philippines to the latitude of the Hawaiian Islands, and thirteen days, or about two weeks, more to reach Los Angeles, where, doubtless, it appeared as a rain-storm coming from a totally different direction,- the south-east. This storm is accurately charted in Chart No. XII. 


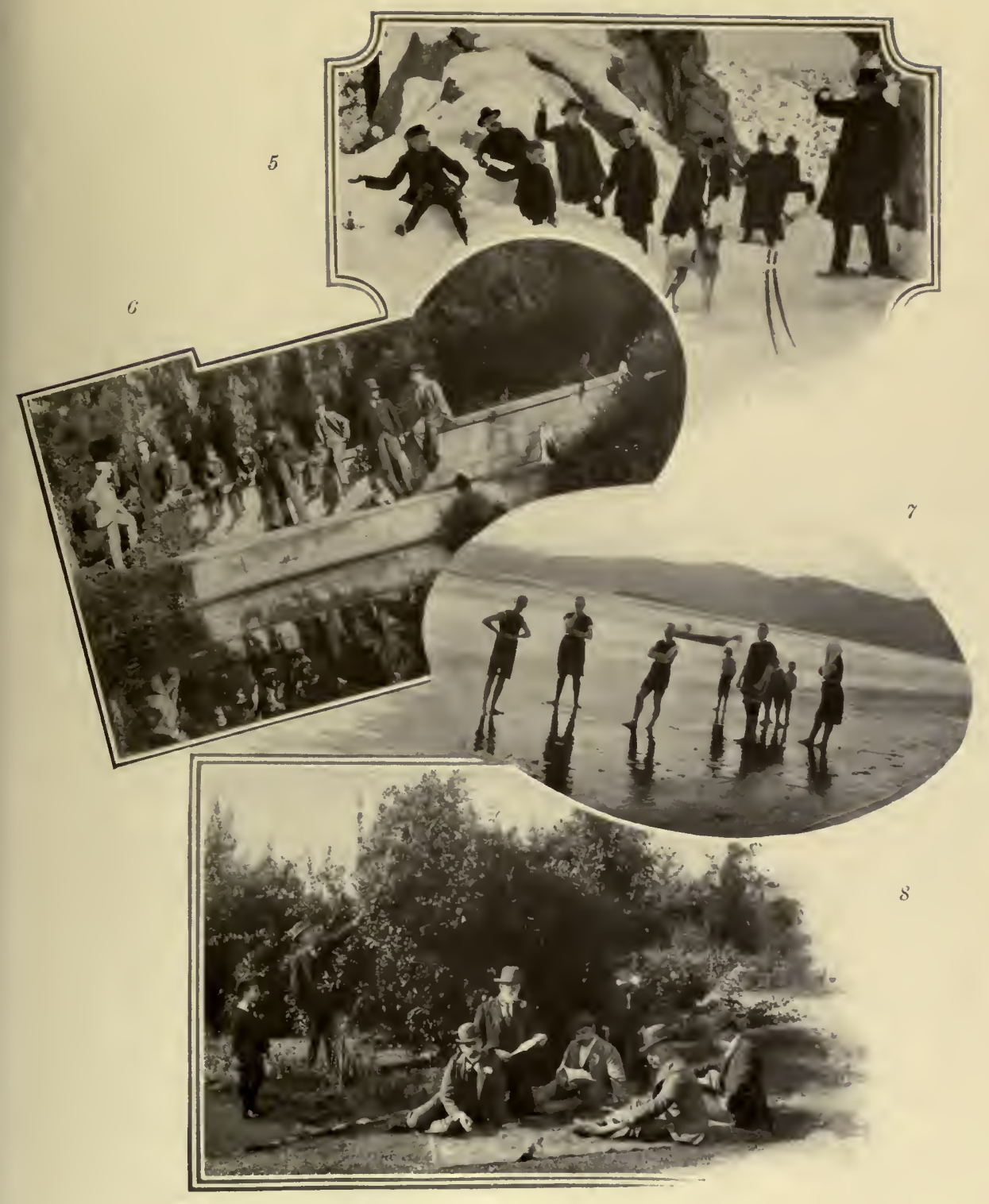

Pasadena's Varied Climates (continucd).

(5) I 2.45 P.M.Snow balling. (6) r.30 P.M. At Trout Pool, MeNally Ranch, Summer again, (7) 3.30 P.M. Bathing in the Pacific at Santa Monica. (8) 5 P.M. Back in a Pasadena, orange grove reading congratulatory telegrams over their feat. 



\section{Climate of Southern California}

in the Report of the Climatology of California, 1903 , and is extremely interesting as showing the devious paths of rain-storms which reach this favored section.

The rainfall of Southern California for a number of years is shown in the following table, which tells the story of minimum dampness and malarial conditions, and a maximum number of sunshiny days in the year. Rainfall in Los Angeles:

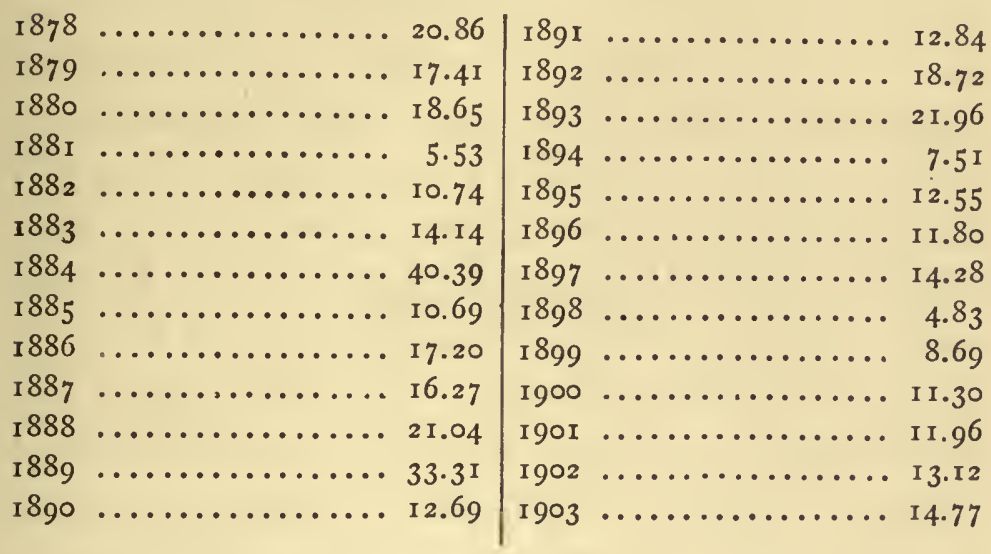

It is not intended here to give an elaborate statement of the climatic conditions, but to present in as few words as possible the reasons for the various climatic phenomena that are so conspicuous in Southern California, and to answer some of the questions that are often propounded by visitors and sportsmen who are spending the season in the State.

Southern California is not a winter resort alone. True, it has climatic attractions at this season that are superior to any in Europe, but to the sportsman who 
would see the beauties of its splendid mountains, its cool sea-coast, and its unexcelled sea-fishing, I commend it as a summer resort, as well. From March or April to December, its life in the open can be enjoyed without interference, and its resorts along shore will be found cooler than any on the Atlantic coast of the United States south of Maine. No storms, no fog in the daytime, an absence of mosquitoes, cool nights, no malaria, and the best big game-fish angling in the world. In winter the land is a garden, and days follow days almost perfect and beautiful. Golf days, we might call them, as then the golfer is in the land, and the fine clubs and links of Santa Barbara, Avalon, Los Angeles, Pasadena, Riverside, and Coronado are now at their best. The days are "fresh," and snow is not met with except in the high altitudes. The lower ranges and their attractive cañons are the winter picnic grounds of Southern California. Many Eastern visitors bring their motor-cars, and the roads are filled with life and colour, from Santa Barbara to Coronado, all during the Californian winter of soft winds and flowers. 
Appendices 



\section{Appendices}

\section{Los Angeles}

Population, 250,000. Annual mean temperature for twenty years, $62^{\circ} .{ }^{1}$ For coldest month, January, $54^{\circ}$; warmest, August, $72^{\circ}$. Average sunshine, 75 per cent. Clear days, 317. Number of thunder-storms in twenty-four years, 32 . Average annual rainfall in twenty-four years, $15.7 \mathrm{I}$ inches. Prevailing direction of wind from April to November, south-west and west. November to March, north and north-east. Prevailing wind, average for twenty-four years, west. Number of days temperature below $32^{\circ}$ in twenty years, 13. (U.S. Station.)

\section{San Diego and Coronado}

Average daily change of temperature, $2^{\circ}$. Extremes in thirty years, $10 I^{\circ}$ and $32^{\circ}$. Temperature has exceeded $90^{\circ}$ but nineteen times in thirty years. Four frosts have occurred in that time. Annual mean, 61. $4^{\circ}$. In 9496 days there were 9I8I days of temperature not above $80^{\circ}$, nor below $40^{\circ}$. Average humidity for January, 74.9; for August, 85.4. Average number of rainy days per annum, 4I. Annual rainfall, 9.52 inches. Average yearly thunder-storms in eleven years, I.

This also relates to Coronado. Professor McAdie says: "The climate of Coronado is substantially that of San Diego. The differences are slight." The climatic conditions of these places are remarkable for minimum lack of change day by day, throughout the year. Coronado temperature average for the year, 6r.7. Average daily range, 13.8. Average number of days clear, 239; partly cloudy, 70 ; cloudy, 56 ; fog, I8; rainy, 42.

\section{Riverside}

85 I feet above level of sea; mean annual rainfall, io inches. Mean annual temperature for I9 years, 62.9. January, 5I.x; August, 76.4.

Riverside is famous for its oranges and well-nigh perfect winter climate. The

${ }^{1}$ These references to the climate of Southern California towns and cities are compiled from the reports of Professor McAdie of the U. S. Weather Bureau of San Francisco. 
summers are warmer than at Los Angeles; nights cool, climate bracing. Summer heat dry, not debilitating.

\section{Redlands}

I,352 feet above sea. Annual average temperature, $64^{\circ}$. Relative humidity low. Annual rainfall (12 years), 54.70 inches. Winters mild and beautiful. Grand mountain scenery, snow-capped mountains. Summers warmer than Los Angeles; heat dry, but not menace to health anywhere in the state.

\section{Pasadena}

Stands at head of San Gabriel Valley. Altitude 828 feet ; 25 miles from ocean. Indiana colony selected locality for town site after examining all Southern California. Nine miles from Los Angeles, second city in Southern California. Annual average rainfall, $I_{3}$ inches. Mean temperature, 59.8; maximum, 85.8; minimum, 39.2. Mean for January, 56.2 ; mean for August, 70.6.

COMPARATIVE AVERAGE TEMPERATURES AT CELEBRATED RESORTS WITH PASADENA AS A TYPE OF SOUTHERN CALIFORNIA INLAND CLIMATE.

\begin{tabular}{|c|c|c|c|c|c|}
\hline PLACE. & Winter. & Spring. & Summer. & Autumn. & $\begin{array}{l}\text { Difference, } \\
\text { Summer } \\
\text { and Winter }\end{array}$ \\
\hline Pasadena $\ldots \ldots \ldots \ldots \ldots$ & 56.00 & $6 \mathrm{r} .07$ & $67.6 \mathrm{r}$ & 62.31 & I 1. $6 \mathrm{I}$ \\
\hline Funchal, Madeira......... & 62.88 & $64 \cdot 55$ & 70.89 & 70.19 & 8.10 \\
\hline St. Michael, Azores....... & 57.83 & 61.17 & 68.33 & 62.33 & 10.50 \\
\hline Santa Cruz, Canaries...... & 64.65 & 68.87 & 76.68 & 74.17 & 12.03 \\
\hline Nassau, Bahama Islands.. & 70.67 & 77.67 & 86.00 & 80.33 & 15.33 \\
\hline Cadiz, Spain............ & 52.90 & 59.93 & 70.43 & 65.35 & 17.53 \\
\hline Lisbon, Portugal.......... & 53.00 & 60.00 & 71.00 & 62.00 & 18.00 \\
\hline Malta................. & 57.46 & 62.76 & 78.20 & 71.03 & 20.74 \\
\hline Algiers................. & 55.00 & 66.00 & 77.00 & 60.00 & 22.00 \\
\hline St. Augustine, Florida.... & 58.25 & 68.69 & 80.36 & 71.90 & 22. II \\
\hline Rome, Italy $\ldots \ldots \ldots \ldots \ldots$ & 48.90 & 57.65 & 72.16 & 63.96 & 23.26 \\
\hline Sacramento, California.... & 47.92 & 59.17 & 71.19 & 61.72 & 23.27 \\
\hline Mentone $\ldots \ldots \ldots \ldots \ldots$. & 49.50 & 60.00 & 73.00 & 56.60 & 23.50 \\
\hline Nice, France $. . \cdots, \ldots \ldots$. & 47.88 & 56.23 & 72.26 & $6 \mathbf{r} .63$ & 24.44 \\
\hline New Orleans, Louisiana.. & 56.00 & 69.37 & 81.08 & 69.80 & 25.08 \\
\hline Cairo, Egypt $\ldots \ldots \ldots \ldots$ & $58.5^{2}$ & $73.5^{8}$ & 85.10 & 71.48 & 26.58 \\
\hline Jacksonville, Florida ..... & 55.02 & 68.88 & 81.93 & 62.54 & 26.91 \\
\hline
\end{tabular}

\section{Santa Barbara}

Like nearly all the seashore towns of Southern California, Santa Barbara has a remarkably perfect climate. It stands on the shore, backed by the Santa Ynez range, protected by the Santa Barbara Islands. The temperature of winter and spring months approximates $56^{\circ}$, summer and fall $63^{\circ}$. The annual mean 


\section{Appendices}

temperature is about $60^{\circ}$. Average yearly rainfall 16.59 inches. It has all the charm of the resorts of Southern France and Italy, with none of the drawbackscold and hot winds.

\section{Santa Monica}

Santa Monica, Redondo, San Buenaventura, Long Beach, Terminal, San Pedro, Ocean Park, Venice, Playa Del Rey, Newport, Huntington Beach, Naples, San Juan, La Jolla, Carlsbad, Alamitos, Laguna, and others are seaside resorts which have cool summers and warm winters-ideal conditions. None have government weather stations, but they vary but little from Santa Barbara as regards extremes of temperature, and the rainfall is about the same.

\section{San Bernardino}

San Bernardino and Colton have about the same conditions of Redlands and Riverside.

\section{Santa Ana}

The climatic conditions of Santa Ana, Tustin, Orange, El Toro, Whittier, San. Juan Capistrano, and other towns of this region are very similar to those of Los Angeles. Nearly all are connected by a network of electric roads, and easily reached from Los Angeles.

\section{Insular Climate of Southern California}

The record of a year (IgO5) at Avalon, Santa Catalina Island, Los Angeles County, California, illustrating the remarkable uniformity of climate and lack of decided change between summer and winter in a climate by no means tropical.

TEMP. AIR

2.0O P.M.

$\begin{array}{cr}\text { Jan. } & \text { I } \\ \text { “6 } & 2 \\ \text { “ } & 3 \\ \text { “ } & 4 \\ \text { “ } & 5 \\ \text { “ } & 7 \\ \text { “ } & 8 \\ \text { “ } & 9 \\ \text { “ } & 10 \\ \text { “ } & 11 \\ & 12\end{array}$

TEMP. WATER

4.00 P.M.

63
63
63
63
65
64
65
64
64
63
60
63

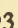

63
3

63
TEMP, AIR

2.00 P.M.

62

62

62

62

62

62

62

63

63

62

62

59

$6 . .1$.
6
6
6
4
5
4
4
3
60
6

Temp. Water

4.00 P.M.

60

63

63

64

66

63

64

62

64

64

65

64

65

65 


\section{Life in the Open}

\begin{tabular}{|c|c|c|c|c|c|c|c|}
\hline & EMP. AIR & & TEMP. WATER & & EMP. AIR & & TEMP. WATER \\
\hline Jan. & $\begin{array}{l}2.00 \text { P.M. } \\
25\end{array}$ & 65 & $\begin{array}{c}4.00 \text { P.M. } \\
65\end{array}$ & Mar. & $\begin{array}{l}2.00 \text { P.M. } \\
\text { I I }\end{array}$ & 64 & $\begin{array}{c}4.00 \text { P.M. } \\
65\end{array}$ \\
\hline 11 & 26 & 62 & 64 & ". & 12 & 62 & 65 \\
\hline “" & 27 & 62 & 65 & " & 13 & 65 & 65 \\
\hline “ & 28 & $6 I$ & 64 & “ & 14 & 63 & 63 \\
\hline “ & 29 & 61 & 65 & “" & I5 & 62 & 63 \\
\hline$" 1$ & 30 & $6 I$ & 64 & "“ & 16 & $6 I$ & 63 \\
\hline “. & $3 \mathrm{I}$ & 53 & 64 & " & 17 & $6 x$ & 63 \\
\hline Feb. & I & 62 & 63 & “" & 18 & $6 \mathrm{I}$ & 66 \\
\hline "6 & 2 & 53 & 64 & “ & I9 & 66 & 66 \\
\hline “" & 3 & 63 & 62 & “ & 20 & 66 & 66 \\
\hline “ & 4 & 61 & 63 & “ & $2 I$ & $6 I$ & 66 \\
\hline “ & 5 & 60 & 64 & “ & 22 & $6 \mathrm{r}$ & 66 \\
\hline “ & 6 & 59 & 63 & “ & 23 & 63 & 66 \\
\hline “ & 7 & 63 & $6_{3}$ & “ & 24 & 64 & 66 \\
\hline$" ،$ & 8 & 63 & 63 & “" & 25 & 64 & 66 \\
\hline “" & 9 & 59 & 63 & “" & 26 & 64 & 66 \\
\hline “ & 10 & 62 & 63 & “ & 27 & 62 & 65 \\
\hline “ & I I & 62 & 63 & “ & 28 & 63 & 62 \\
\hline “ & I2 & 57 & 69 & “ & 29 & 62 & 62 \\
\hline$"$ " & 13 & $5^{8}$ & 62 & “ & 30 & 58 & 67 \\
\hline “ & 14 & 64 & 63 & “ & $3 I$ & 64 & 62 \\
\hline “" & 15 & 61 & 62 & Apr. & I & 62 & 66 \\
\hline “" & 16 & 63 & 64 & $\because$ & 2 & $6 I$ & 64 \\
\hline " & 17 & 62 & 63 & “" & 3 & 63 & 66 \\
\hline “ & 18 & $6 I$ & 63 & " & 4 & 60 & 65 \\
\hline " & I9 & 62 & 63 & “ & 5 & 62 & 64 \\
\hline “ & 20 & 62 & 64 & “ & 6 & 60 & 65 \\
\hline “" & $2 I$ & 65 & 64 & ". & 7 & $6 I$ & 60 \\
\hline$"$. & 22 & 70 & 63 & " & 8 & $6 I$ & 62 \\
\hline “" & 23 & $6_{3}$ & 63 & ". & 9 & $6 \mathrm{I}$ & 62 \\
\hline " & 24 & 60 & 64 & “" & ro & 61 & 63 \\
\hline “ & 25 & 60 & 64 & “ & I I & 60 & $6 t$ \\
\hline “ & 26 & 63 & 65 & “" & I2 & 62 & 63 \\
\hline “ & 27 & 63 & 65 & " & I3 & 64 & 66 \\
\hline "، & 28 & 63 & 65 & “ & 14 & 62 & 65 \\
\hline Mar. & I & 65 & 66 & “" & I5 & 64 & 63 \\
\hline “ & 2 & 72 & 67 & “ & 16 & 63 & 66 \\
\hline " & 3 & 68 & 70 & “" & I7 & 62 & 64 \\
\hline “" & 4 & 60 & 64 & ". & 18 & 65 & 64 \\
\hline “" & 5 & $\sigma_{3}$ & 65 & ، & I9 & 64 & 63 \\
\hline “ & 6 & 63 & 67 & ". & 20 & 65 & 64 \\
\hline "، & 7 & 64 & 67 & “" & $2 I$ & $6 \mathrm{I}$ & 62 \\
\hline "، & 8 & 64 & 66 & a & 22 & 66 & 64 \\
\hline 16 & 9 & 64 & 65 & “ & 23 & 66 & 64 \\
\hline " & to & 64 & 65 & “ & 24 & 66 & 65 \\
\hline
\end{tabular}




\section{Appendices}

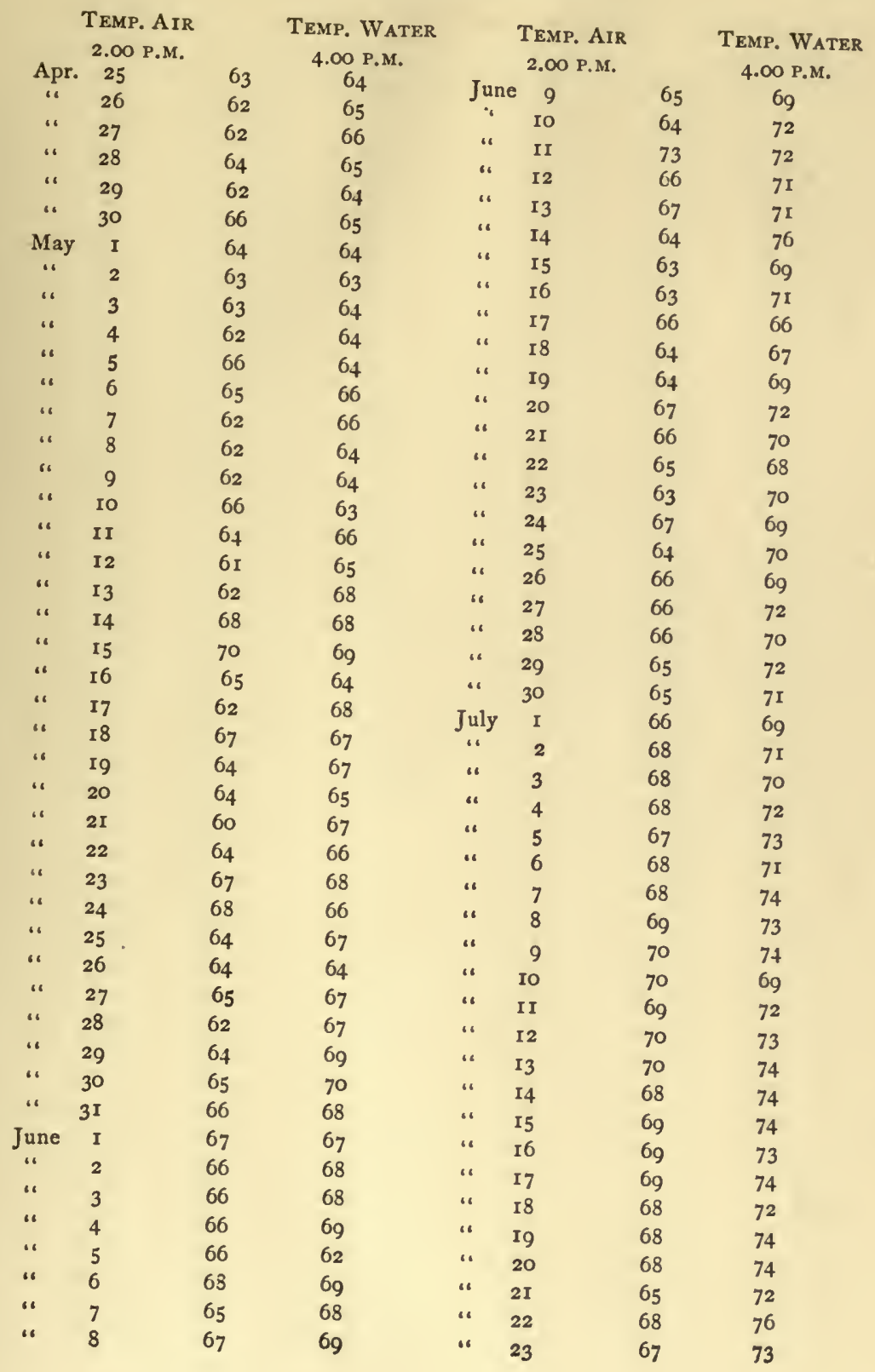




\section{Life in the Open}

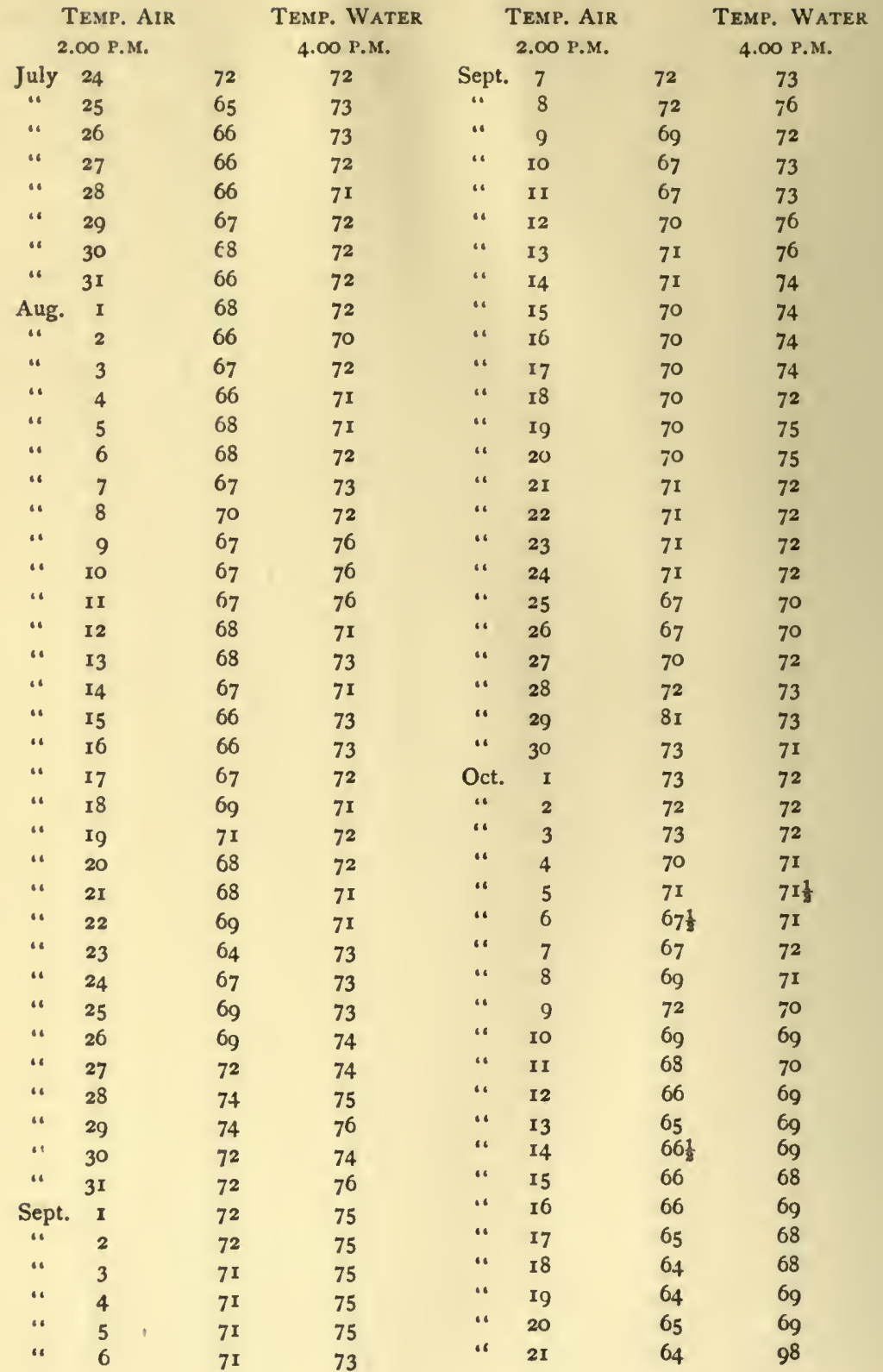




\section{Appendices}

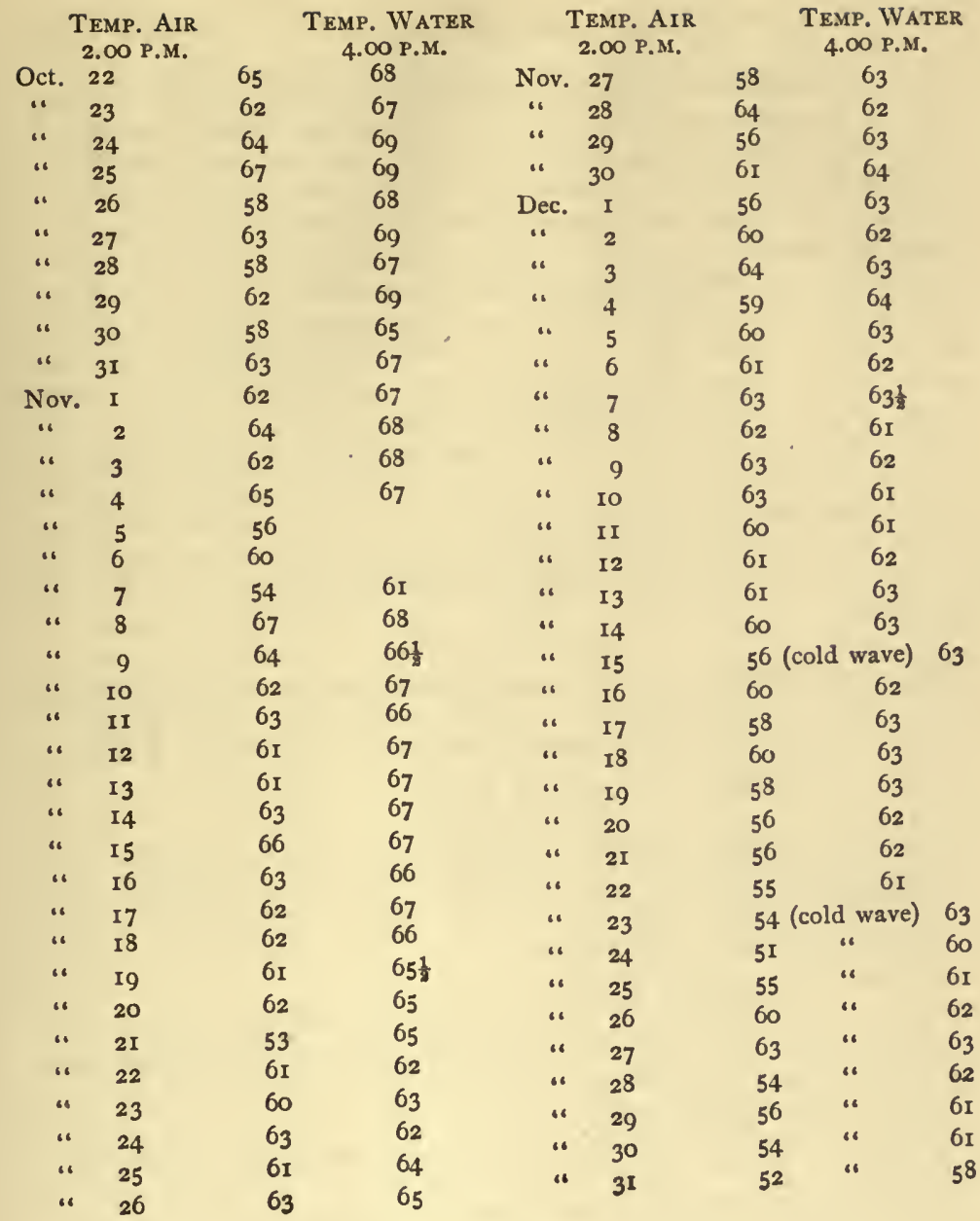




\section{Résumé}

The remarkable features of the insular climate of Southern California are well shown in the record of Avalon. January and February are the coldest months here, and the general average temperature in the shade or under a piazza is about $63^{\circ}$; the temperature of the ocean, about $64^{\circ}$. Notice the lack of extremes day after day. In August the general average may be said to be about $66^{\circ}$ or $67^{\circ}$, or four or five degrees warmer than the average in mid-winter. In a word, here is a climate having a minimum of changes, a temperate climate, yet allowing a flora of palm and other tropical forms. The highest temperature in July, 1905, was $72^{\circ}$. the lowest $65^{\circ}$, which tells the story of a summer much cooler than any on the Atlantic Coast. The highest temperature in August was $74^{\circ}$; the highest in September, $81^{\circ}$, on one day; the highest in all other days in September being $74^{\circ}$. The hottest day in October was $73^{\circ}$, the coolest $58^{\circ}$. The warmest day in November was $66^{\circ}$, the coolest $53^{\circ}$. December, I905, saw the coldest weather Southern California has experienced in twenty years; old residents voted it extremely disagreeable. The lowest temperature at Avalon during this month was $51^{\circ}$, the highest $64^{\circ}$. The lowest sea (bathing) temperature was $58^{\circ}$, the highest $64^{\circ}$.

\section{California State Game and Fish Laws-Open Season 1905-1906-For Closed Season Reverse the Dates}

\section{BAG LIMIT}

Quail, rail, grouse, snipe, curlew, ibis, plover, doves-25 in one day.

Ducks -50 in one day.

Deer, male-2 in one season.

Deer-August ist to October I5th.

Doves-July ist to February I5th.

Mountain quail, grouse, sage hen-September Ist to February I5th.

Valley quail, ducks, ibis, curlew, plover, rail-October 15 th to February $15^{\text {th. }}$.

Snipe-October I5th to April Ist.

Trout-April ist to November Ist.

Steelhead Trout-October I6th to February Ist. A pril Ist to September Ioth. Two seasons.

Salmon-October 16th to September Ioth. Above tide water close season extends to November I5th.

Lobster or crawfish-(Not less than $9 \mathrm{~T} / 2$ in. long) - September I5 th to April Ist.

Black bass-June Ist to January Ist.

Crab-(No crab taken less than 6 in. across the back)-November Ist to September Ist.

N. B. - In some counties the open seasons are shorter.

Fine for violation of game laws $-\$ 25$ to $\$ 500$ and imprisonment. Fine for violation of fish laws $-\$ 20$ to $\$ 500$ and imprisonment. Sinallest fine for using explosives to take any kind of fish $-\$ 250$ and imprisonment. 


\section{Appendices}

\section{Los Angeles County Game Laws-Changes Made by County Ordinances in Open Seasons}

Deer: August 15 to October I.

Doves: August I5 (only one day).

Mountain quail : September I to October 15.

Valley quail : October 15 to February I.

\section{Santa Barbara County}

Deer : August I to September I.

\section{Riverside County}

Deer: August I to September I5.

Mountain trout : May I to July I.

\section{San Bernadino County}

Doves: September 15 (only one day).

Mountain quail : September I to October I5. $_{5}$

Valley quail : October 15 to February $I$.

Trout : May 15 to November I.

\section{Oceanic Game Fishes in Season}

Tuna (summer months best)-June, July. Black sea bass-June to November. White sea bass-April to November. Yellowtail-March to December. Sheepshead, albacore, bonito, rock bass, whitefish-all the year. BarracudaJune to September. Sword-fish-June to September. Surf-fish, yellowfin-all the year.

\section{LIST OF OCEANIC GAME FISHES}

taken with rod and reel in Southern California waters and maximum, weights :

Leaping tuna (Thunnus thynnus), 250 lbs. Black sea bass (Stereolepisgigas), 429 lbs. Whitefish (Caulolatilus princeps), I 5 lbs. Yellowtail (Seriola dorsalis), $50 \mathrm{lbs}$. White sea bass (Cynoscion nobilis), $80 \mathrm{lbs}$. Albacore (Germo alalunga), 17 lbs. Yellowfin, albacore (Germo macropterus), 50 lbs. Bonito (Sarda chiliensis), 20 lbs. Sheepshead (Pimelometopon pulcher), 20 lbs. Barracuda (Sphyraena argentea), 15 lbs. Sea trout (Cynoscion parvipinnis), 6 to to lbs. Striped bass (Roccus linneatus), ${ }^{1} 30$ lbs. Montery Spanish mackerel (Scomberomorus concolor), Io lbs. Pez de gallo (Nematistius pectoralis), 60 lbs. Common sword-fish (Xiphias gladius), 200 lbs. Short-sword sword-fish (Tetrapturus), 150 lbs. Halibut (Paralichthys californicus), 30 lbs. Mackerel (Scomber japonicus), 6 lbs. Black rockfish (Sebastodes mystinus), 6 lbs. Orange

${ }^{1}$ The striped bass has just begun to appear in Southern California waters, and was introduced at San Francisco. 
rockfish ( $S$. pinniger), ro lbs. Yellow rockfish ( $S$. miniatus), 8 lbs. Red rockfish (S. ruberrimus), ro lbs., $2 \frac{1}{2}$ feet long. Yellow-tailed rockfish (S. flavidus). Blue-mouth cod (Ophidion elongatus), 40 lbs. Blue perch (Medialuna californiensis), 5 lbs. Rock bass (Paralabrax clathratus), 12 lbs. Spotted Cabrilla (Fonnyverde), 5 lbs. Opah, 50 lbs. (rare). Oceanic bonito, (Gymnosarda pelagmis) 20 lbs.

\section{The Lacey Act, Passed by Congress May 25, 1900}

Prohibits interstate traffic in birds and game killed in violation of State law, regulates the importation of foreign birds and animals, and prohibits absolutely the introduction of certain injurious species ; also makes it unlawful to ship from one State to another game killed or captured in violation of local laws, and which require all packages containing animals or birds to be plainly marked so the name and address of the shipper and the nature of the contents may be ascertained by inspection of the outside of such packages.

The act also prohibits interstate commerce in game killed in open seasons, if the laws of the State in which such game is killed prohibit such export. In referring to these provisions of the act, the House Committee on Interstate Commerce reported as follows :

"The killing or carrying of game within the limits of a State is a matter wholly within the jurisdiction of the State, but when the fruits of the violation of State law are carried beyond the State, the nation alone has the power to forbid the transit and to punish those engaged in the traffic. The bill will give the game wardens the very power that they now lack and which will be the most effective for the purpose of breaking up this commerce. . . . In some of the States the sale of certain game is forbidden at all seasons without regard to the place where the same was killed. The purpose of these laws is to prevent the sale of game shipped into the State from being used as a cloak for the sale of game killed within the State in violation of the local laws."

\section{What Is Always Unlawful}

To buy, sell, barter or trade, at any time, any quail, pheasant, grouse, sage hen, rail, ibis, doves, plover, snipe, or any deer meat or deer skin.

To have in possession doe or fawn skins.

To take or kill, at any time, does, fawns, elk, antelope or mountain sheep.

To take or kill pheasants, or bob-white quail, or tree squirrels.

To run deer with dogs during closed season.

To shoot half hour before sunrise, or half hour after sunset.

To trap game of any kind without first having procured written authority from the Board of Fish Commissioners.

To take or destroy nests or eggs of any birds.

To ship game or fish in concealed packages, or without your name and address.

To buy or sell trout less than one pound in weight.

To take, at any time, sturgeon, or female crabs.

To take abalones less than 15 inches in circumference. 


\section{Appendices}

To take trout or black bass, except with hook and line.

To take salmon, shad or striped bass with a net less than $71 / 2$-inch mesh.

To fish with boat and net without a license.

To fish for salmon with nets Saturday and Sunday.

To use a set-net.

To take fish, in any manner, within 50 feet of a fishway.

To take, buy or sell striped bass less than three pounds in weight.

To shoot meadow-larks or other song birds.

To shoot on enclosed land without permission.

\section{Southern California U. S. Forest Reserve Rules}

No firearms are allowed in the Santa Barbara, San Gabriel, San Bernardino, San Jacinto or Trabuco Canyon Reserves except under a permit issued by the Forest Supervisor in charge.

Shotguns are entirely excluded from the San Gabriel and San Bernardino Reserves. No permits are issued to minors in these two reserves.

Permits are issued at any time, and are good to the end of the calendar year in which they were issued.

The following conditions are printed on permits :

(I.) Carry the permit whenever in the reserve with guns.

(2.) Submit cheerfully to inspection of permit and gun.

(3.) Will not mutilate live timber or any other property.

(4.) Observe the game laws.

(5.) Extinguish fires before leaving the camp.

Those desiring permits in Santa Barbara County should address B. F. Crawshaw, Forest Supervisor, Santa Barbara. In Ventura County, William M. Slosson, Forest Supervisor, Nordhoff, Cal. In Los Angeles and San Bernardino Counties, address Everett B. Thomas, Forest Supervisor, Los Angeles, Cal. In Riverside County, W. C. Bartlett, Forest Supervisor, San Jacinto, Cal.

The attention of the public is called to the danger of leaving camp-fires burning. Fires are not allowed to be built unless a space of five feet is cleared around the fire. No fires are allowed closer than twenty feet to a hillside. The penalty for leaving fires burning is $\$ 1000$ fine or one year's imprisonment.

Fire-crackers and fire-works are not permitted in the reserves. Forest rangers act as game-wardens.

For further information call at the office of Forest Supervisor, Everett B. Thomas, Room I03 Potomac Building, Los Angeles, Cal.

\section{List of Clubs in Southern California Organised for Hunting and Fishing and Golf.}

Bolsa Chica Gun Club.-Count Jaro von Schmidt, President, No. I Chester Place, Los Angeles, Cal.

Cerritos Gun Club.-Rob. E. Ross, Secretary, California Club, Los Angeles, Cal. 
Del Rey Club, - W. H. Stimson, Secretary, Stimson Block, Los Angeles, Cal. La Patera Gun Club.-Louis C. Larson, Secretary, Goleta, Cal.

Tuna Club.-Avalon, Cal.

Santiago Hunting Club.-N. N. Brown, Secretary, Santa Ana, Cal.

Recreation Gun Club.-J. Frankenfield, Secretary, IOO7 South Hill Street, Los Angeles, Cal.

Laguna Gun Club.-J. A. Graves, Secretary, Baker Block, Los Angeles, California.

Lomita Gun Club.-Dr. O. P. Roller, Secretary, 221 $\frac{1}{2}$ South Spring Street, Los Angeles, Cal.

Santa Paula Gun Club.-A. W. Elliott, Secretary, Santa Paula, Cal.

Upland Gun Club.-A. G. Allen, Secretary, Upland, Cal.

Sherifrs' Club.-F. H. Brakesuhler, Secretary, Court House, Los Anles, Cal.

Blue Wing Duck Club.-C. Van Valkenburg, Secretary, California Bank Building, Los Angeles, Cal.

Santa Monica Gun Club.-C. C. LeBas, Secretary, Santa Monica, Cal.

Fair View Gun Club.-R. H. Sanborn, Secretary, Tustin, Cal.

Sisquoc Rangers.-W. H. Granger, Secretary, San Buenaventura, Cal.

Christopher Land and Water Co.-C. C. Merrill, Secretary, H. W. Heltman Building, Los Angeles, Cal.

Guadalupe Duck Club.-E. C. Tallant, Secretary, Santa Barbara, Cal.

Chico Land and Water Co.-Ed. R. Maier, Secretary, 440 Aliso Street, Los Angeles, Cal.

Aloha Gun Club.-A. W. Marsh, Secretary, Temple Block, Los Angeles, Cal.

Whittier Gun Club.-Carroll Proud, Secretary, Whittier, Cal.

Alamitos Gun Club._-G. E. Franklin, Secretary, Trust Building, Los Angeles, Cal.

San Bernardino Gun Club.-F. C. Moore, Secretary, San Bernardino, Cal.

Centinella Gun Club.-J. W. A. Off, Secretary and Treasurer, Second and Spring Sts., Los Angeles, Cal.

Redlands Gun Club.-W. C. Whittemore, Secretary, Redlands, Cal.

Riverside and Arlington Gun Club.-Owen Council, Secretary and Treasurer.

Greenwing Gun Club.-A. M. Goodhue, Secretary, Long Beach, Cal.

Glendora Rifle Club.-F. C. Neet, Secretary, Glendora, Cal.

Ontario Gun Club.-E. V. Caldwell, Secretary, Ontario, Cal.

Pastime Gun Club.-N. D. Nichols, Secretary, San Diego, Cal. Cal.

Creel Club.-Fred A. Walton, Secretary, Lankershim Block, Los Angeles,

Pomona Gun Club.-J. A. Gallup, Secretary, Pomona, Cal.

Pine Cliff Club.-Hancock Banning, Secretary, Los Angeles, Cal.

Cadwell Gun Club.-L. A. Báiley, Secretary, Long Beach, Cal.

Valley Hunt Club.-Dr. F. F. Rowland, President, Pasadena, Cal.

The Maryland Hunt-Pasadena, Cal.

The Pasadena Gun Club. 


\section{Appendices}

Pasadena Country Club (Golf).

San Rafael Golf Club-San Rafael Ranch, Pasadena, Cal.

San Gabriel Golf Club.

Los Angeles Country Club (Golf).

Avalon Golf Club-Santa Catalina Is., Cal.

Santa Barbara Country Club (Golf, Polo).

Riverside Country Club (Golf, Polo).

Coronado (Golf) Club.

Orange Golf Club.

\section{Acknowledgments}

The photographs used in this volume were taken by Harold A. Parker of a Colorado St., Pasadena, Cal., Messrs. Putnam and Valentine, Los Angeles, Cal., C. C. Pierce \& Co., Los Angeles, Cal., Charles Ironmonger \& Co., Avalon, Cal. J. G. Brewster, San Buenaventura, Cal., The Graham Photo Co., Los. Angeles, Cal., and C. J. Crandall \& Co., Pasadena, Cal., and others. 



\section{Index}

Abalone fisheries, 345

Adenostoma, 43

Alamitos, 5 I

Albacore fishing, 301-302

Aliso, 204

Alpine Tavern, 142

Amber-fish, 35 I

Anacapa Island, 192, 329

Angel-fish, 32 I

Antelope, I74-177; range, 174;

description, I75; Valley, I74

Arroyo Seco River, 26, 83, 2 I3

Arch Rock, 205

Argus Peak, 148

Automobiling, $18 \mathrm{I}-207$

Avalon, 230, 262, 330, 331

Avocet, 59, I 22

Azusa, 197

Bait Club, 86

Balsa Chica, $5^{\text {I }}$

Banning, Captain William, 280

Barracuda, 3 r 3

Barton Flats, r44,

Bass, black, 97

Bats, I 25

Beach fishing, 346

Beard, S. M., 250

Bear Lake, 97 ; Valley, 144

Bently, Dr., 25 I

Bighorn, the, I29-134; on Ensenada, $\mathrm{I}_{29}$; range of, $\mathrm{r}_{3} \mathrm{r}$

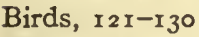

Bittern, least, 123

Blackbirds, 54

Black Current of Japan, 375

Black Jack Peak, 225

Bonito fishing, $30 \mathrm{I}-304$
Brandegee, Prof. T. F., 337

Brown, Jason, 2 II ; Owen, 2 I I

Brown's Peak, 148

Burns, William C., 27; pack of Kentucky thoroughbreds, 27

Cabrillo, Juan Rodriguez, I89

Cabrillo Mountains, 226

Cacitas Pass, I88

Camulos, r 92

Cañons of the Sierra Madre, 85

Carlsbad. 203

Carnegie Institute, solar observatory, $\mathrm{r}_{42}$

Carpenteria, 189

Channel Islands, 234; cruising among, 329; flora, 337-338

Chaparral, density of, 46

Chino, 2 I 3

Cienega Seco, I44

Climate, for Southern California, 339; San Clemente, 339; Santa Cruz, 339, 36r; Santa Catalina, 339; Santa Rosa, 339; in San Gabriel Valley, 365; rainy season, 369 ; variety of, 363 ; from Pasadena to Alpine Tavern, 363,364 ; conditions which affect, $3^{6} 5$

Climatology, of California, report of, 379

Coaching, from Santa Barbara to the Mission of San Diego deAcala, 18I, 207; at Santa Catalina, 275,284

Cold Water Creek, 94

Colton, 197

Condor, 123 
Cooper Ranch, 187

Coots, $5^{8}$

Corinthian Yacht Club, $34^{\circ}$

Coronado Islands, 204, 329

Corral Harbour, 332

"Cottontails," 27

Coyote, hunting, I03-118; range, I 8

Cranes, 53; sand-hill, 59

Creel Club, 86

Cucamonga, 197

Dark Cañon, 144

Deep Creek, $9^{8}$

Deer hunting, 39, 47; in the San Rafael Hills, 42 ; in Santa Barbara, 46; in San Diego, 46; San Jacinto, 46 ; guides necessary, 47

Del Mar, 202

Devil Cañon, 144

Devil's Gate, 94

Doves, mourning, 124

Dowitcher, long-billed, I 23

Duarte, 197

Ducks, 54; varieties, 57

Dumetz, Padre Franscisco, 192

Eagle Nest Inn, 282

Eaton Cañon, 92

Eddy, Col. R. A., 25 I

Elizabeth Lake, I74

E1 Montecito, I 88

Elms, H., $33^{8}$

Elsinore, 76

E1 Toro, 4, 204

Encenitas, 202

Ensenada, I 30

Falkland Islands, 238

Fallbrook, 20 I

Farallones, 237

Fierasfer, 324

Fiesta of San Luis Rey, 199

Fillmore, 94

Follow's Camp, 93

Fox hunting, 65, 75; seasons, 7475; tree-climbing, 69; coast, 70; hounds, California, 73
Fredalba, 145

Gallinule, 59

Garvanza, 26

Gaviota Pass, 188

Geese, wild, 52, 53; varieties, 57;

Canada, 60; Hutchin's, 61

Glass-bottom boat, 240, 3 I 7-326

Gleason's Peak, 148

"Glen Annie" Ranch, I87

Goat, wild, 225-234

Godwit, marbled, I 23

Gonzales Ranch, 198

Gophers, I 24

Greyhounds, I 3, I 4

Grizzly Peak, 148, 149

Groupers, 3 I 3

Gulls, I 22

Hale, Dr. George E., 92, $4_{42}$

Hammer-heads, 3 I 3

Heron, blue, I 23

Heteromeles, 43

Hollister Ranch, 187

Howland's, 284

Hueneme, 192

Humming-birds, 124

Ibis, wood, 123

Indio, I 76-1 77

Jack-rabbit, hunt, 4, 15; in San Fernando Valley, 12 ; in Pomona, I 2; in Ontario, I 2 ; Riverside, I 2 ;

Redlands,12; San Diego, I2;

Coronado, 12 ; hunting vs. Coursing, $14^{-15}$

Jess, George B., 25 I

Kelp (Macrocystes), 237-257; fish $239,240,323-324$

Killdeer, 59

Kinglets, 125

Kinney, Abbot, 99

Kuroshiwo, 243

Laguna, 205

Laguna Cañon, 76

La Jolla, 204

Lake Elsinore, I98

Landmarks Club, 192 


\section{Index}

"Language of the hunt," 35

Las Cacitas, I37.

Leaping-shark fishing, 346-347

Lipton Cup races, 340

Lipton, Sir Thomas, 340

Little Bear Valley, I 44

Little Harbour Inn, 28 2

Lizards, I 24

Long Point, 290

Los Angeles, I9; river, I9, 83, 94, Los Robles, 4

Lynx, hunting, I9-36; description of, 29-30; species of 29-30

McAdie, Prof. Alexander G., 376

Maneadro Valley, I 30

Maryland Hunt Club, I 8

Matilija Cañon, 94

Merriam's anletope, range map, I74

Middle Ranch Cañon, 230, 232, 28 I

Millard Cañon, 2 I3

Missions, 206-207

Mojave desert, 167 I77; mirage in, I68; vegetation, I $7 \mathrm{I}$

Monrovia, 197

Moorehouse, Col. C., 27 I

Morays, 322

Mother Mountains, 220

Mountain-lion, I37-I 5 I ; range, I 39

Mountain-sheep, I 29-I 34

Mount Conejo, I48; Cucamonga, I48, I5I; Cuyamacha, 202; Palmar, I98; San Antonio, 194; San Bernardino, I48; San Jacinto, I94; Santa Margarita, 202; Santiago 85; Tanquiz, 143

Mount Lowe, elevated road, 142

Mount Wilson trail, 92; observatory, 92

Murietta, I98

Murphy, L. G., 25 I

Negro Cañon, 2 I 3

Neve, Governor Felipede, I9 I

Newport, I 2 I

Nordhoff, 94

Nordhoff, Mr., I33
Ocean sapphires, 324

Ontario, I97

Orange, I25; County Park, 28; hunts, 28-29

Orcas, $29 \mathrm{I}$

Orioles, 125

Orizaba Peak, 225

Oromo, Tony, 24 I

Page, Dr. Benjamin, 28, 29, 97

Painted Cave, the, 291,292

Pala, 77; Mission, 200

Palm Springs, 170

Palomar, 77

Palos Verde, $5^{I}$

Parker, C. E., 73

Pasadena, 87, 194-195; Country Club, 27

Pauba Ranch, I98

Pebble Beach, 230

Perris, I98

Piers, 343; from Santa Monica to San Diego, 343; at Long Beach, 343; at Venice, 344; at Ocean Park, 344

Pigeons, band-tailed, 124

Pine Creek, 94

Pleasants, J. E., M. H. Santiago Hunt Club, 28, 73

Plover, 59, I 23

Point Diablo, 291

Point Firmin, I 2 I, 345

Pomona, I97

Poppy, Matilija, 76

Port Hartford, 3 Io

Portuguese Bend, 345

Presidio of Santa Barbara, I9I

Pronghorn, the, I67, I77

Priente Hills, $32 \mathrm{I}$

Puma, I 39, I 5 I

Quail, 27; valley, I 23, I $55, I 63$; description, I56; grounds, I57; range of, I60; mountain, I6I; desert or Gambel's, I 62

Raccoon, 26-27, 125

Radebaugh, Dr. John M., 374 
Rain-storms in the mountains, 217 , 218

Rain, cause of, 377

Rainfall in Los Angeles, 379

Rat, wood-, 125

Ravens, 125

Raymond Hill, 193

Raymond, Walter, I93

Rider, F. V., $25^{\circ}$

Riverside, 197

Robin, I 25

Rose-tree foxhounds, experiences with, 31, 32

Rowland, Dr. F. F., 30

Salmo iridius, 89

Salton sink, the, $150,{ }_{7} 6$

San Buenaventura Mission, 188 , I9I, 192

Sandpiper, 59; spotted, 153

Sandpit Cañon, 144

San Clemente, 237, 283, 289, 329, 33 I

San Diego Mission, 203

San Diego Yacht Club, 340

San Fernando, I 92 ; Mission, 192

San Gabriel Archangel, 195-197

San Gabriel Cañon, fishing in, 86;

Mission, 4 ; River, 83 ; Peak, 148

San Gorgonio Chasm, I $5^{\circ}$

San Jacinto River, 198

San Juan Capistrano Mission, 76, 204

San Luis Obispo, 27

San Luis Rey de Francia, 20 I

San Luis Rey Mission, 76, $201-$ 202

San Mari o hounds, ro

San Miguel, 329; Islands, 333

San Nicolas, 283, 295, 329, $33^{1-332}$

San Pedro, 262

San Rafael Hills, 26

Santa Ana, 205

Santa Ana River, 83

Santa Anita Ranch, r 94

Santa Barbara Mission, 184-186;
Islands, 329 ; Rock 329 ; Harbour. 335

Santa Catalina, 225; coaching in, 277 ; Islands, 329

Santa Clara River, 95

Santa Cruz, 291, 329, 333

Santa Margarita Rancho, 76

Santa Maria, Vincente de, 192

Santa Monica, I 2 I

Santa Paula, r92; Creek, 94

Santa Rosa, 289, 329, 333, 334;

Island, 295; Ranch, 198

Santa Ynez range, 84

Santiago Hunt Club, 28, 73, I 8

Sea-bass, 243, 257; angler's equipment, 254; -lions, 289, 297; trout, 3 I 2

Seal Rocks, 231

Seriola, $35^{\mathrm{I}}$

Serra, Father Junipero, I9I

Serranos, the, 29

Sheep, bighorn, I 29-1 34

Sheep's-head, 325

Ship Rock, 285

Shooting clubs, 56

Short, Dr. J. de Barth, II 2, 197

Shrubs, I46, 147

Sierra Santa Monica, the, 84, 192

Sierra Madre, the, $83-100$; life in, 2 I I-2 2 I

Sisar River, 94

Sulphur Mountain, 94

"Skip-jack" fishing, 305

Snipe, Wilson's, I 23

Soledad Cañon, 95

South Fork, I 44

South Coast Yacht Club, 33 I

Sparrows, 125

Sphinx, the, 249

Spider crabs, 32 r

"Sprig," 55

Squirrels, ground, 124

Still angling, 343-347; at Alamitos, 327 ; at Port Los Angeles, 347; at Redondo, 347 


\section{Index}

Stilt, black-necked, 122

Summer camps, I 45

Sunny Slope, hounds, I2; Ranch, I94

Surf-fish, 3 I 4

Swallows, 125

Switzer, Commodore, 212

Tattler $\mathbf{I}_{23}$

Tejunga River, 95

Temecula, I98

Temperature in Southern California, 339; comparison with Riviera resorts, 339

Tern, royal, I27; Foster's, 122

Thrush, 125

Tia Juana, 204

Tiburon, 309

Trees, 145, 146; tree-climbing dogs, 23

Trolling, deep sea, 30I-306

Trout fishing, in the Sierra Madre, 82-100; in the Arroyo Seco, 8791; in the San Gabriel River, 92 ; in Santa Ynez Mountains, 93; in the Sespe 93, season in California, 95; gameness of California, 89; weight, 95 ; stocking, 96-97
Tuna Club, 243, 262; tournament, $25 \mathrm{x}$; fishing, $26 \mathrm{r}-272$; tackle, 263 , 264; record catch, 27 I

Turnstone, black, 123

Tustin, 206

Valley Hunt hounds, I0, 13, 104; meet, ro3

Viele, Gen. Charles, 249

Vulture, California, I 23

Warblers, 125

Warner Ranch Indians, 198

Weakfish, 309-312; at Santa Catalina 3 ro; at San Clemente, 3 I0

White Rock, 290

Willet, western, I 23

Winds, 374,375

Wilson's snipe, $5^{8}$

Wolf Ranch, 198

Wotkyns, Grosvenor, 133

Wrens, I 25

Yachting, 335, 336

Yellow-fin, 30 I

Yellow-tail, $35^{1}$; run of, 352 ; fishing at Avalon Bay, 353; description of, 356; gameness, 357: range of, $35 \mathrm{I}$

Zalvidea, Padre Jose Maria, I97 



\section{THE WORKS OF THEODORE ROOSEVELT}

\section{Standard Library Edition.}

8 volumes, $8^{\circ}$, illustrated . . each, $\$ 2.50$ $\begin{array}{ll}\text { Cloth per set, } & 20.00 \\ \text { Half calf extra, " } & 40.00\end{array}$ THE WINNING OF THE WEST.

Four volumes, with Maps . . each, $\$ 2.50$

From the Alleghanies to the Mississippi, I769-1776.

From the Alleghanies to the Mississippi, I776-1783.

The Founding of the Trans-Alleghany Commonwealths, I784-I790.

Louisiana and the Northwest, I79I-I809.

“. . A lucid, interesting narrative, written with the impartial soberness of history, warmed and colored by a lively imagination. . . The work is admirably done, and forms a valuable contribution to the history of the country." -London Spectator.

"For the first time the whole field has been covered in one work by one accomplished and thoroughly equipped writer, whose book will rank among American historical writings of the first order."-Critic.

\section{THE WILDERNESS HUNTER.}

With an Account of the Big Game of the United States, and its Chase with Horse, Hound, and Rifle. With illustrations by Remington, Frost, Sandham, Eaton, Beard, and others. $8^{\circ}$.

Standard Library Edition . . . \$2.50

"A book which breathes the spirit of the wilderness and presents a vivid picture of a phase of American life which is rapidly passing away, with clear, incisive force." $-N . Y$. Literary News.

"For one who intends to go a-hunting in the West this book is invaluable. One may rely upon its information. But it has better qualities. It is good reading for anybody, and people who never hunt and never will are sure to derive pleasure from its account of that part of the United States, relatively small, which is still a wilderness." $-N$. Y. Times.

New York - G. P. PUTNAM'S SONS - London 


\section{THE WORKS OF THEODORE ROOSEVELT}

\section{HUNTING TRIPS OF A RANCHMAN.}

Sketches of Sport on the Northern Cattle Plains. With 27 full-page wood engravings and 8 smaller engravings from designs by Frost, Gifford, Beard, and Sandham.

$8^{\circ}$. Standard Library Edition . . . . \$2.50

"One of those distinctively American books which ought to be welcomed as contributing to raise the literary prestige of the country all over the world." $-N . Y$. Iribune.

"One of the rare books which sportsmen will be glad to add to their libraries. . . Mr. Roosevelt may rank with Scrope, Lloyd, Harris, St. John, and lıalf a dozen others, whose books will always be among the sporting classics."-London Saturday Review.

\section{THE NAVAL WAR OF I812; or, The History of the} United States Navy during the Last War with Great Britain.

Sth edition. With diagrams. $8^{\circ}, \mathrm{pp} . \mathbf{x x x v i i i . ~}+53 \mathrm{r}, \$ 2.50$

"Shows in so young an author the best promise for a good historianfearlessness of statement, caution, endeavor to be impartial, and a brisk and interesting way of telling events." $-N$. Y. Times.

"The reader of Mr. Roosevelt's book unconsciously makes up his mind that he is reading history and not romance, and yet no romance could surpass it in interest." -Philadelphia Times.

\section{AMERICAN IDEALS, and Other Essays, Social and} Political.

With a Biographical and Critical Memoir by Gen. Francis V. Greene. $12^{\circ}$, gilt top . . . . \$1.50 Standard Library Edition, $8^{\circ} \quad$. $_{2} \quad . \quad 2.50$

"These essays are energizing, sound, and wholesome. They deserve to be widely read."-Chicago Tribune.

"These are papers of sterling merit, well worth perusing, and deserving their rescue from the files of the periodicals in which they first appeared, to form a more easily accessible volume. Mr. Roosevelt's reputation as a municipal reformer should secure them a wide sale." -Detroit Free Press.

\section{ADDRESSES AND PRESIDENTIAL MESSAGES.} 1902-1904.

With Introduction by Henry Cabot Lodge. $12^{\circ}, \$ 1.50$ Standard Library Edition. $8^{\circ}$. . . $\quad 2.50$

New York - G. P. PUTNAM'S SONS - London 



Return to desk from which borrowed.

This book is DUE on the last date stamped below.

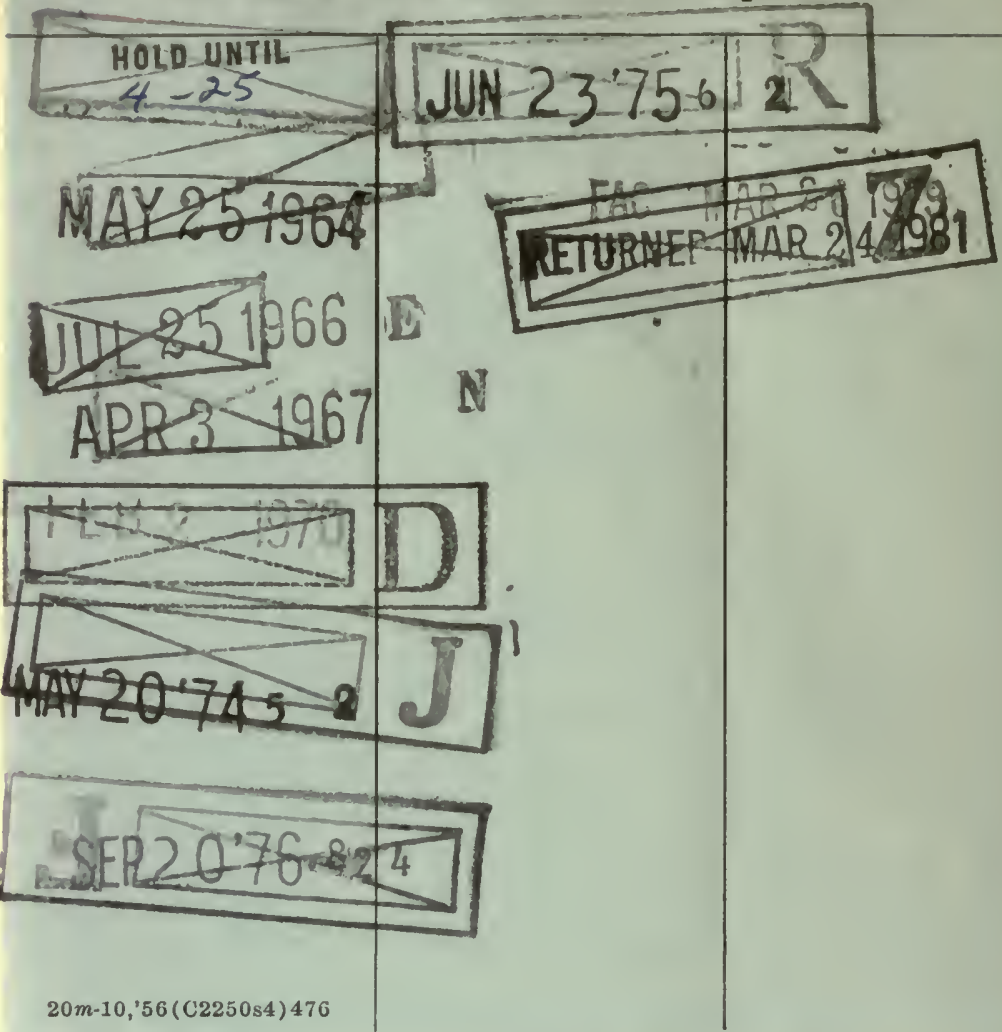




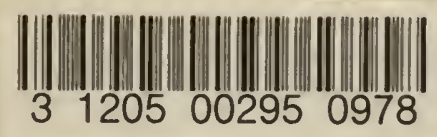


5 